Historic, Archive Document

Do not assume content reflects current scientific knowledge, policies, or practices. 



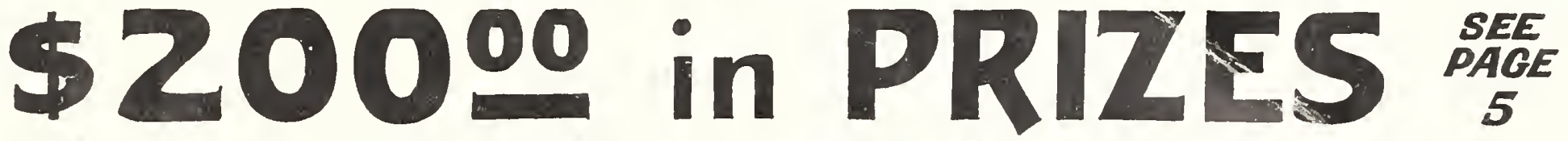
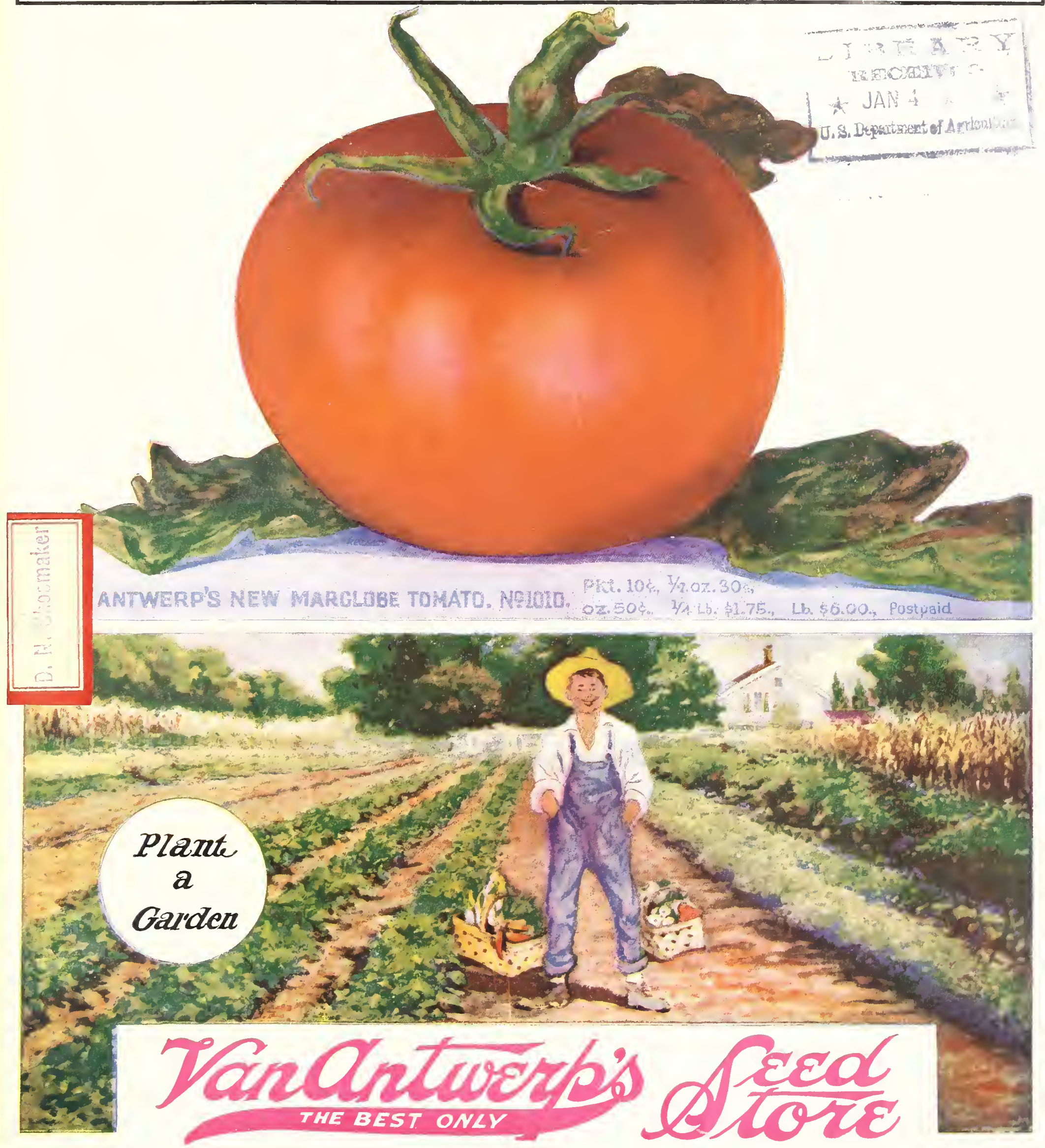

Van Antwerp Building 


\section{Van Antwerp's Free Flower Seedis}

\section{Order Today and get these beautiful flowers}

With Every Order of $50 \mathrm{c}$ or More

\section{Packets Free} charge with every order of 50c or over. The lovely 1928 collection conor

1 Pkt. Early Flowering Cosmos.

Planting Instructions will be Found on the Back of Each Packet
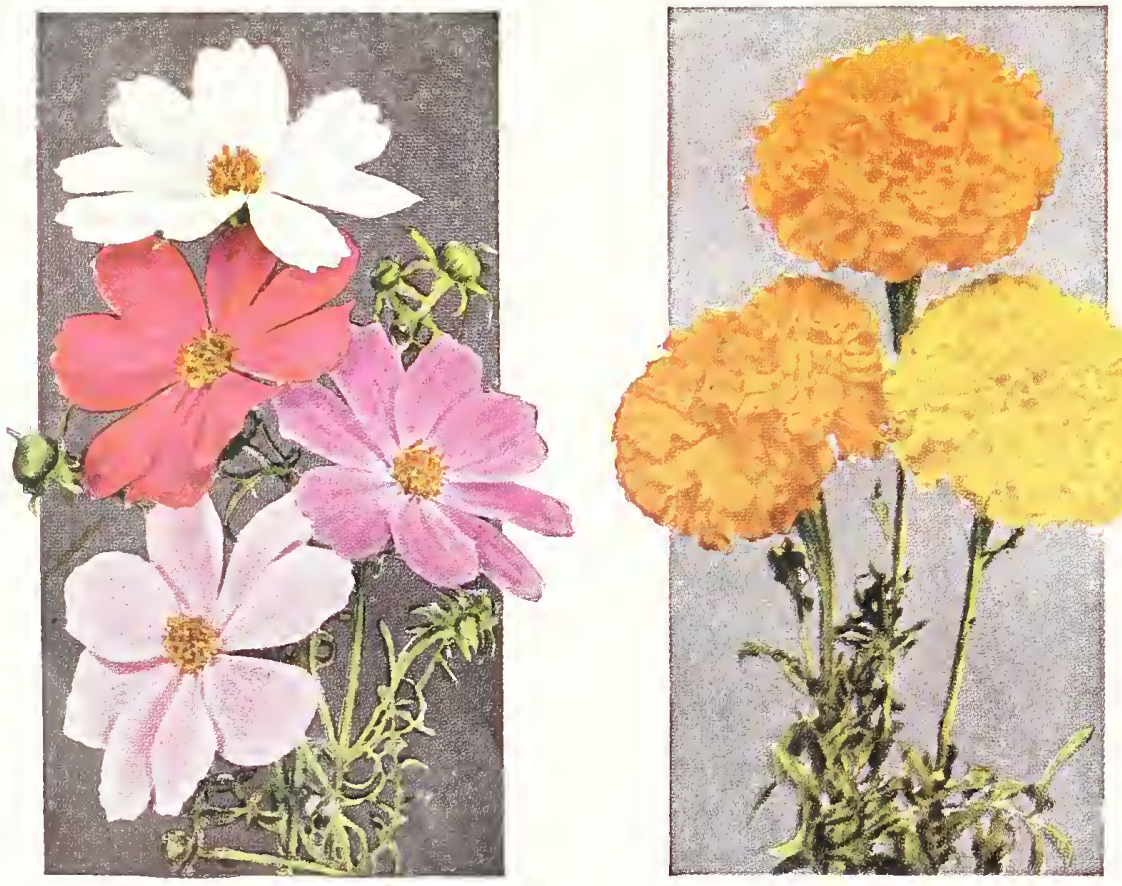

Tall African Marigolds.

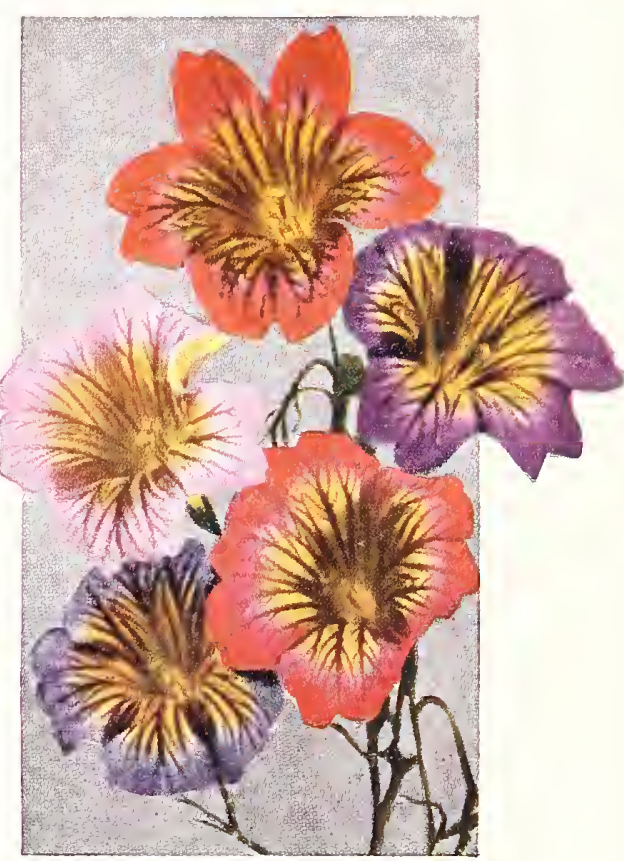

Giant Mixed Salpiglossis. 


\section{SPECIAL NOTICE \\ $10 \%$ EXTRA VALUE GIVEN IF YOU ORDER EARLY}

During the spring months we get thousands of seed orders by mail. Our rush season is from February 15th till the end of April.

Naturally, we would like to have some of these orders come in earlier, when we can give more particular attention to each individual order. It is worth our while to give $10 \%$ extra value to any of our customers who order early.

\section{FOR 6 WEEKS ONLY}

With each dollar's worth of seeds ordered between January 1 and February 12, 1928, we will include, absolutely free, an extra $10 \mathrm{c}$ packet of vegetable or flower seeds, your own selection.

If you send us your order before February 12, 1928, and it amounts to one dollar, you may select in addition one regular $10 \mathrm{c}$ packet of seeds FREE. If your order amounts to two dollars, you select two packets free, and so on.

This offer applies only to retail mail orders sent us, with remittance for Vegetable seeds, Flower seeds or Bulbs. We cannot give any extra value on orders for Field seeds, Potatoes, Fertilizer, Implements, Poultry Feeds and Supplies.

\section{ORDER TODAY}

Take advantage of this liberal offer and send us your order today. Remember you also get the 4 packets of free Flower Seeds with an order of $50 \mathrm{c}$ or over. See inside front cover.

\section{VAN ANTWERP'S SEED STORE Mobile, Alabama}





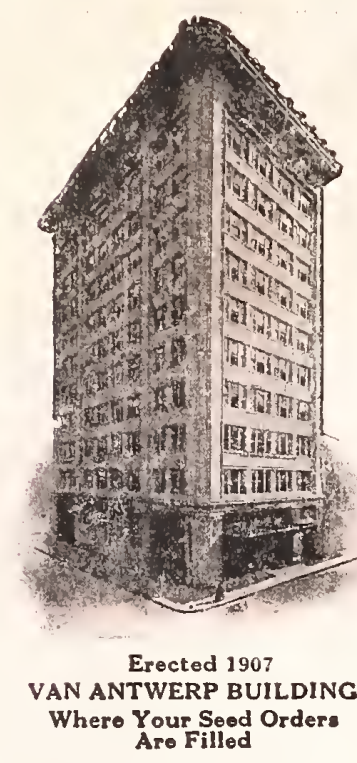

Order No...............

Filled by.............

Checked by............

Please do not write in above space.

If goods are wanted C. O. D. 25 per cent. of amount must accompany the

No plants shipped C. O.D.

\section{SEED ORDER BLANK ${ }_{1028}^{\text {Fo }}$}

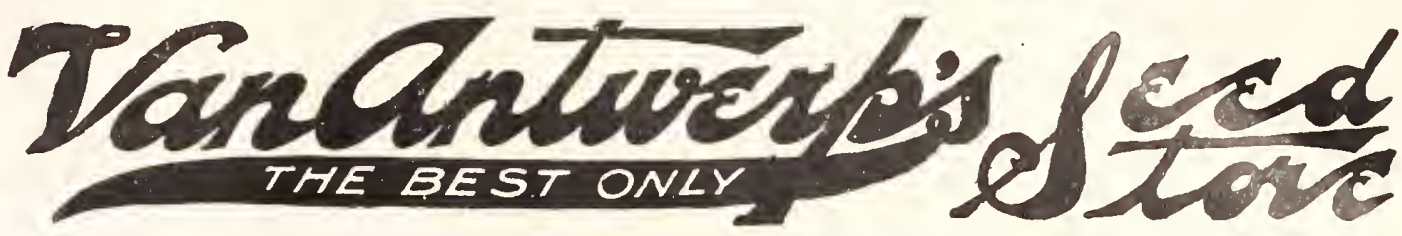

MOBILE, ALABAMA

BE SURE TO FILL OUT THESE BLANKS PLAINLY. The more careful you NOTJCE — are in filling out the following blanks plainly and correctly, the more certain you are of receiving your order promptly and satisfactorily.

Gentlemen $:-1$ am enclosing....................... for the following seeds to be sent by

(State here if wanted by Mail, Express or Freight.)

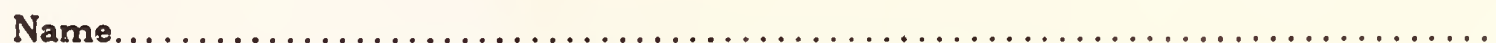
(If Mrs. kindly use husband's initials or give name, as Mrs. John W. Jones.)

P. 0 .

R. F. D. No.

. State.

Express or Freight Office

(If different from your Post Office.)

SEEDS POSTPAID BY PARCEL POST-Please bear in mind that the prices given in our catalog include delivery on all seeds by packet ounce, quarter pound, pounds. two pound, and 5 pound lots, unless ctherwise specified, to all post offices within the boundaries of the United States.

Send us the amount named in our catalog, and we guarantee safe delivery by postpaid parcel post in these quantities. This does not include pecks and bushels

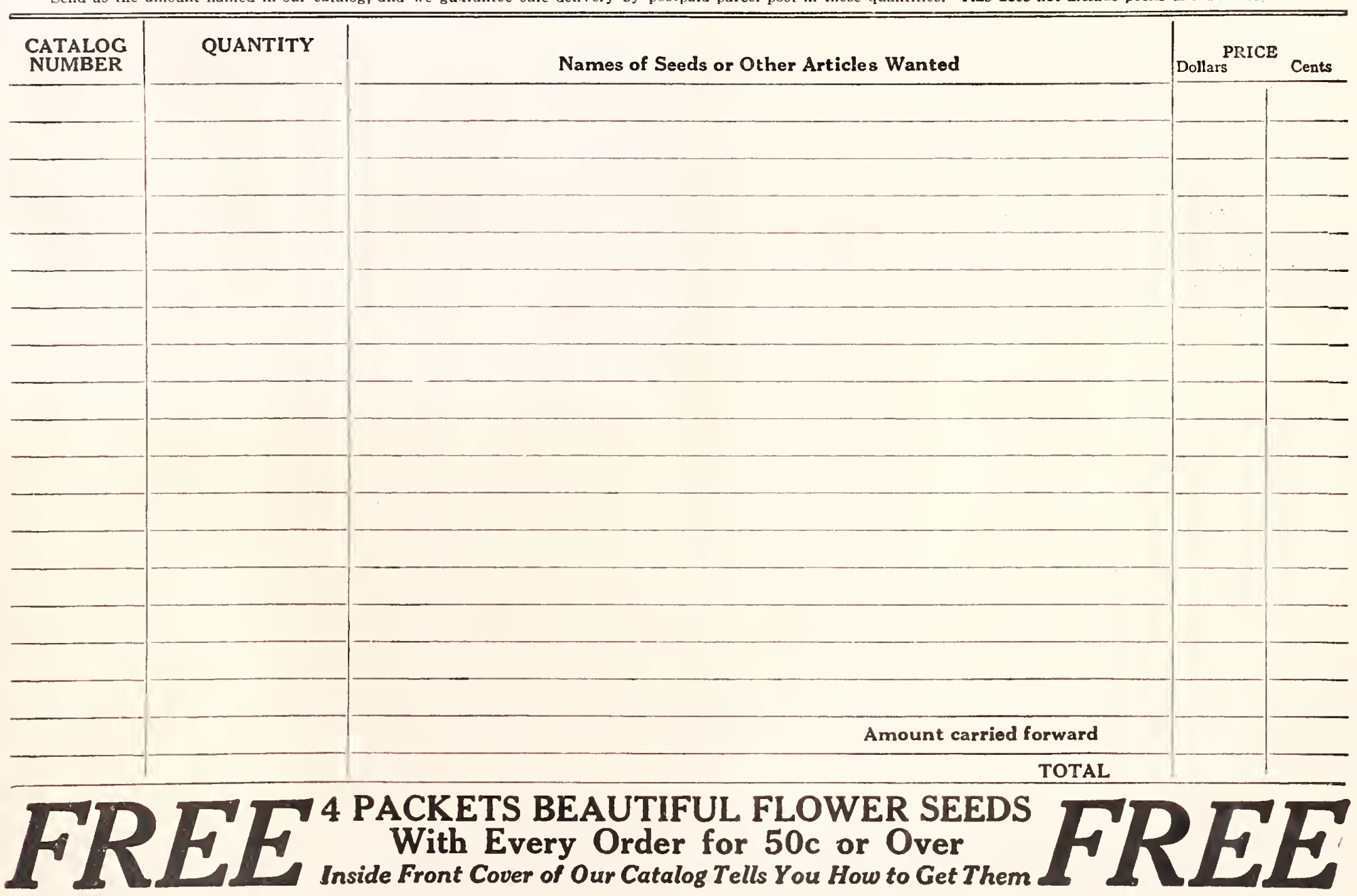




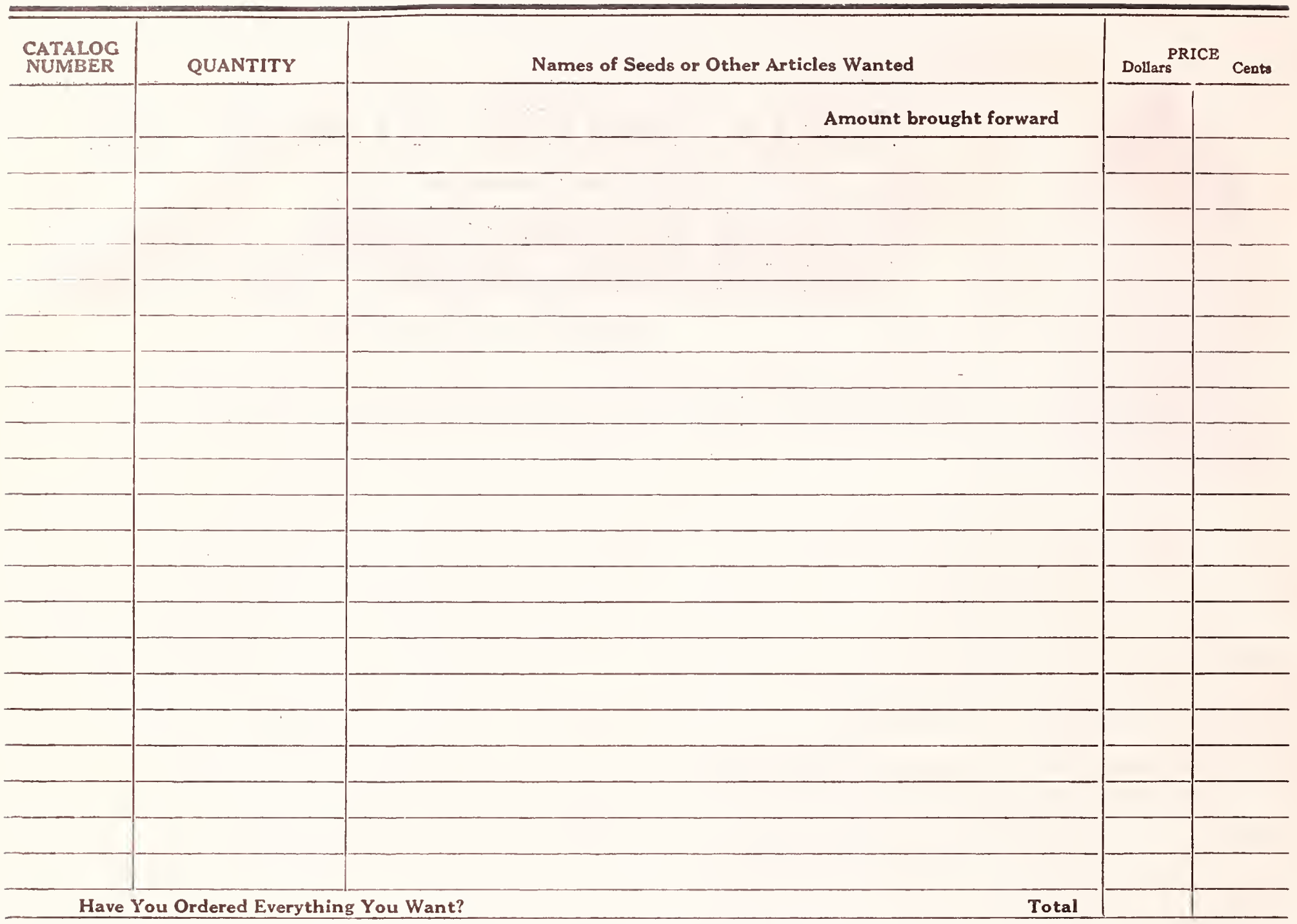

\section{YOUR SAVING IS IN VAN ANTWERP'S PROFIT-SHARING CERTIFICATES}

\section{See Page 3 for Complete Information About These Certificates}

We are anxious to obtain the names and correct postoffice addresses of a number of your friends and acquaintances who are farmers and gardeners who you think would be interested in receiving our Catalog. We are extremely anxious that this list be made absolutely correct so far as postoffice, name and rural route is concerned, and in order that you may use care in compiling same we will give you FREE an assortment of FOUR of our choice VEGETABLE SEEDS, our selection for garden use, if you will fill out the blank below and send it with an order for Seed or other articles selected from our Catalog.

\begin{tabular}{c|c|c|c|c|c|c|c|}
\hline NAMES & POSTOFFICE & R. F. D. & COUNTY \\
\hline & & & \\
\hline & & & & \\
\hline & & & & \\
\hline & & & & \\
\hline
\end{tabular}

To Van Antwerp's Seed Store-The above list of names is correct.

Please sign your name and address here:

In accordance with the universal custom of the Seed Trade, Van Antwerp's Seed Store gives no warranty, express or implied, as to description, quality, productiveness, or any other In accordance with the universal custom of the Seed Trade, Van Antwerp's Seed Store gives no warranty, express or implied, as to description, quality, productiveness, or any other
matter, of any Seeds, Bulbs or Plants it sells and will not be in any way responsible for the crop. If the purchaser does not accept the goods on these terms, they are at tonce to be returned. 


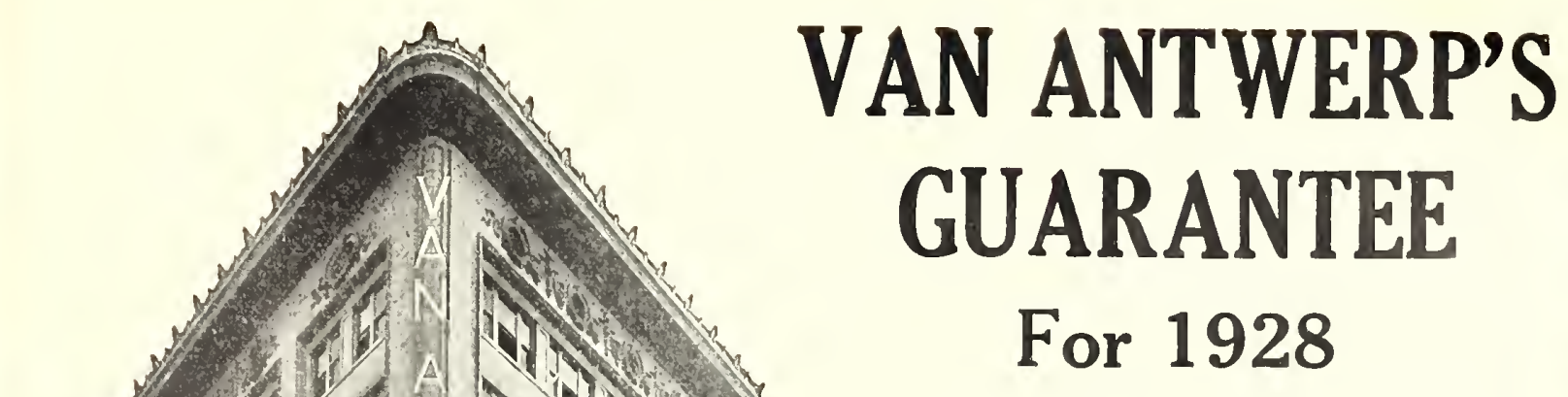

The germination and purity of all the Vegetable Seeds, Flower Seeds or Bulbs we sell are GUARANTEED by us and should they fail to grow, if promptly and properly tested by customers, we will replace the same or give full value in other seeds. As we cannot personally direct the planting of all the seeds we sell, or control anywhere or at any time the natural laws affecting the germination or growth of seeds; it is therefore agreed that in no case shall Van Antwerp's Seed Store be liable for more than the amount actually paid for the seeds or bulbs.

We also guarantee the safe arrival at your home of the seed orders you send Van Antwerp's.

Our Seeds and Service must be satisfactory as many of our customers have been with us for over 50 years and they still plant VAN ANTWERP'S SEEDS. For real SUCCESS with that Small Home Garden or that Thousand Acre Farm sow Van Antwerp's Tested Guaranteed Seeds in 1928.

Send your orders to a seed house that has grown for 50 years-from one of the smallest seed stores to one of the largest in the world-also remember that every packet or bag of seed you order from Van Antwerp's Seed Store has the Van Antwerp Guarantee back of it.

\section{VAN ANTWERP'S SEED STORE}

This Is the Home of

The South's Leading Seedsmen For 1928
The Standard For Over 50 Years

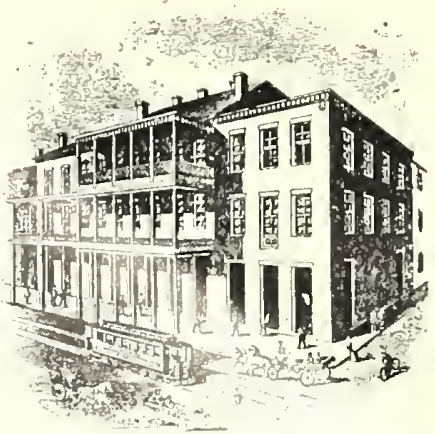

This Is Where We First sold Sceds Over 50 Years A 


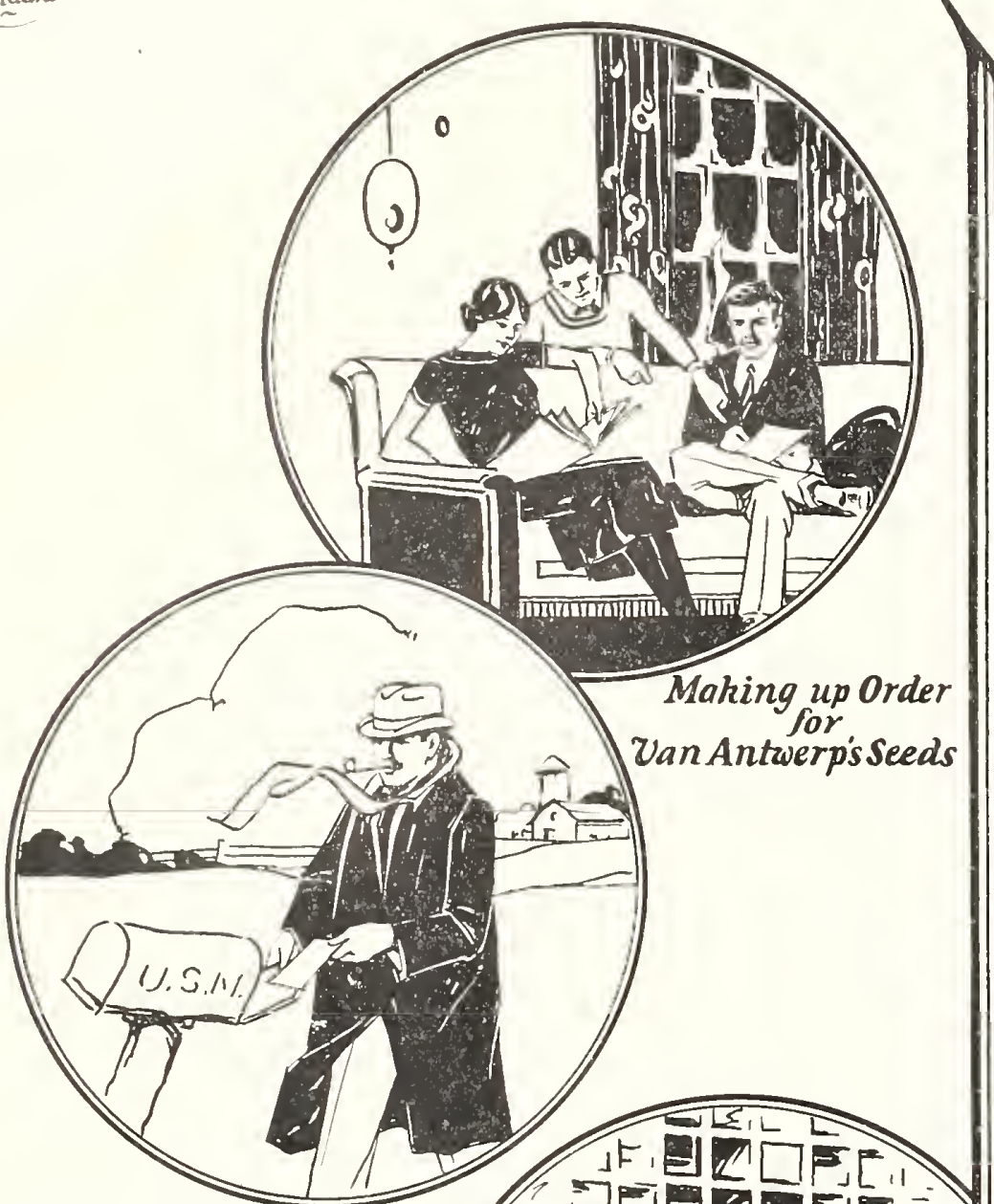

\title{
ORDER TODAY BY MAIL
}

\section{RECEIVE TOMORROW BY MAIL}

\author{
Van Antwerp's Seeds
}

Are as Near to You as Your Nearest Mail Box

\section{How to Order}

WE PAY POSTAGE-On ali seeds offered in this catalog by the packet, onnce, quarter pound, pound, two-pound and fivefumd quantitics, we pay the postage and guarantee safe delivery

our home. Order your seeds by number.

YOU PAY POSTAGE-On all seeds you order in lots over five pounds Jour pay the postage or express and youl also pay the postage or express on quantity lots of Bulbs and Plants. On Poultry Supplies, Implements, Insecticides and Fertilizers, large or small quantities, you pay postage, express or freight.

EXPRESS AND FREIGHT SHIPMENTS-If you wish your seeds to come by Express or Freight, we can send them collect and you can pay the transportation charges on delivery.

When you order some items at "Postpaid" prices and others "Not Prepaid" prices and you want them to all come by Parcel Post, add postage for the "Not Prepaid" items only.

HOW TO SEND MONEY-Remittances should be made by post office money orders, express money orders, drafts or checks. Where it is not possible to obtain these, the letter should be registered.

CASH WITH ORDER-Customers will please remit when ordering. If goods are wanted C. O. D., 25 per cent, or one-fourth of the amount, must accompany the order. No plants shipped C.O.D Prices quoted in this catalog are subject to change without notice.

\section{PARCEL POST RATES}

DOMESTIC POSTAL RATES

Each AdOn Seeds, Plants, Bulbs, Roots, etc, within the First ditional U. S. and Possessions. Pound Pound

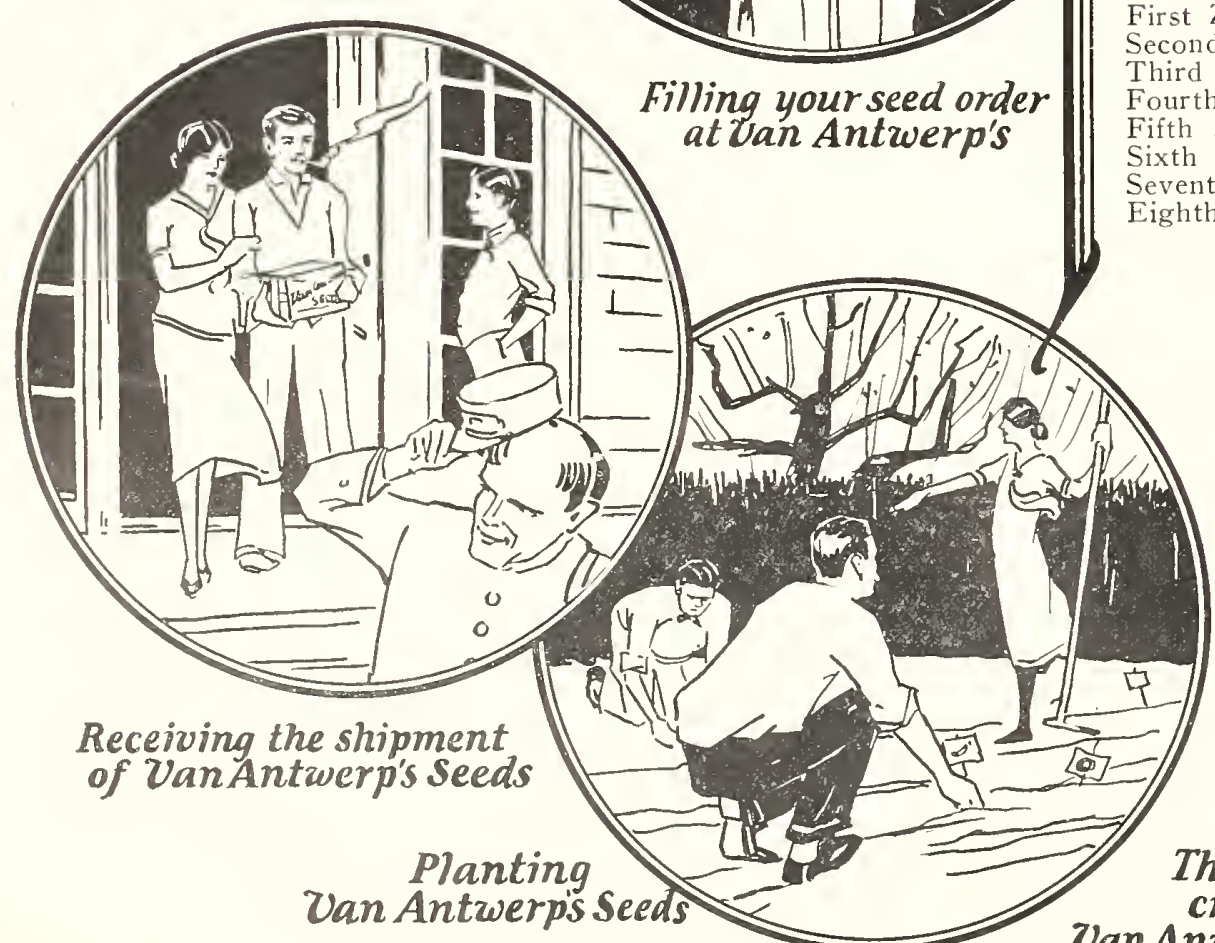
First Zone, Mobile and within 50 miles of Mobile $i c$ ic Zone, within 50 to 150 miles of Mobile $7 \mathrm{c}$ 1c Third Zone, within 150 to 300 miles of Mobile 8c $2 \mathrm{c}$ Fifth Zone, withm 300 to 600 miles of Mobile $9 \mathrm{c}$ Sixth Zone, within 1000 to 1400 miles of Mobile 11c 8c Sever with 1400 to 1800 miles of Mobile $13 \mathrm{C} \quad 10 \mathrm{C}$ ighth Zone, all over 1800 miles of Mobile $14 \mathrm{c}$

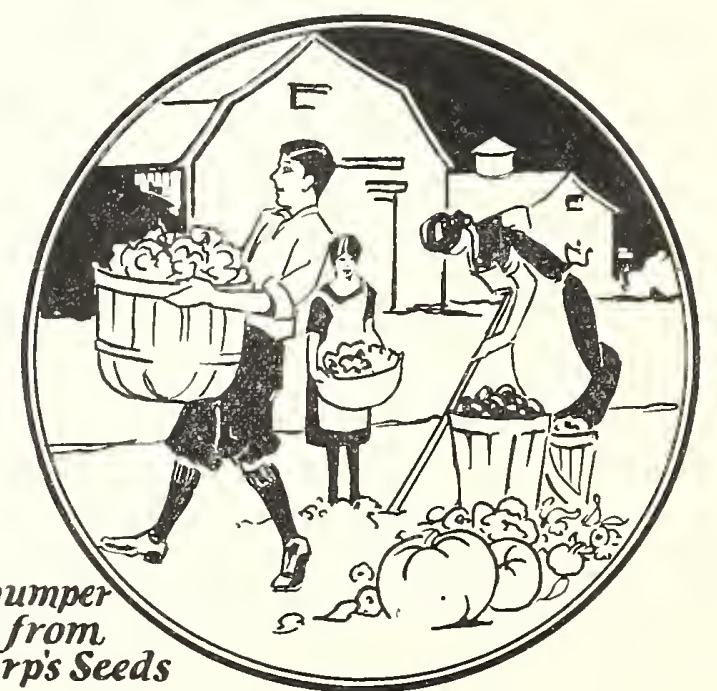




\section{PROFIT-SHARING CERTIFICATES}

\section{FREE \\ WITH EVERY VAN ANTWERP ORDER \\ FREE}

Now Is Your Opportunity to Cash In on the Certificates We Sent

You With Your Orders Last Spring and Last Fall

THEY COUNT AS CASH ON YOUR ORDER THIS

YEAR

YOUR

SAVINC

IS IN

THESE PROFIT-

SHARING

CERTIFICATES

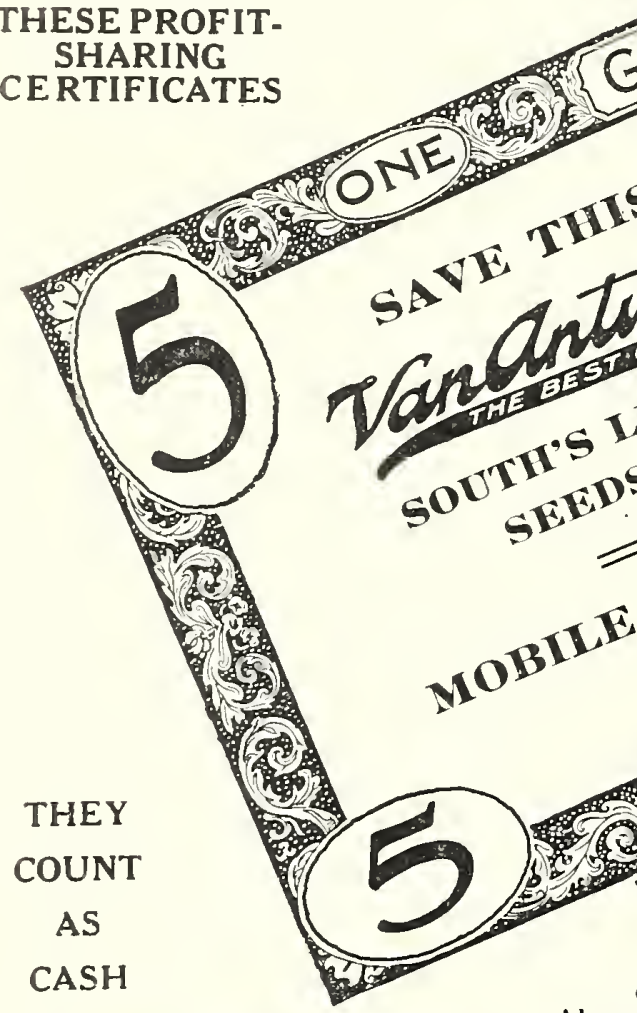

Also remember that we will not redeem less than 10 Certificates at a time.

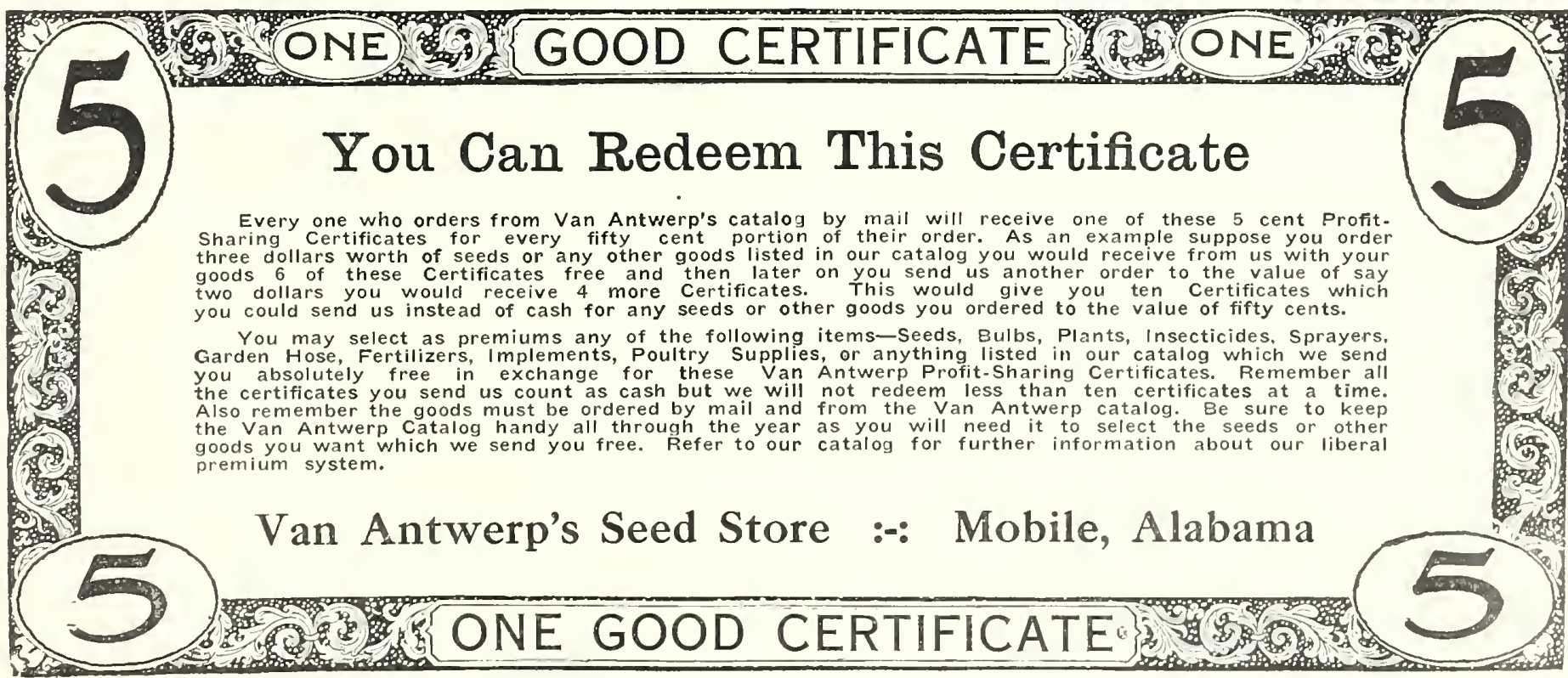




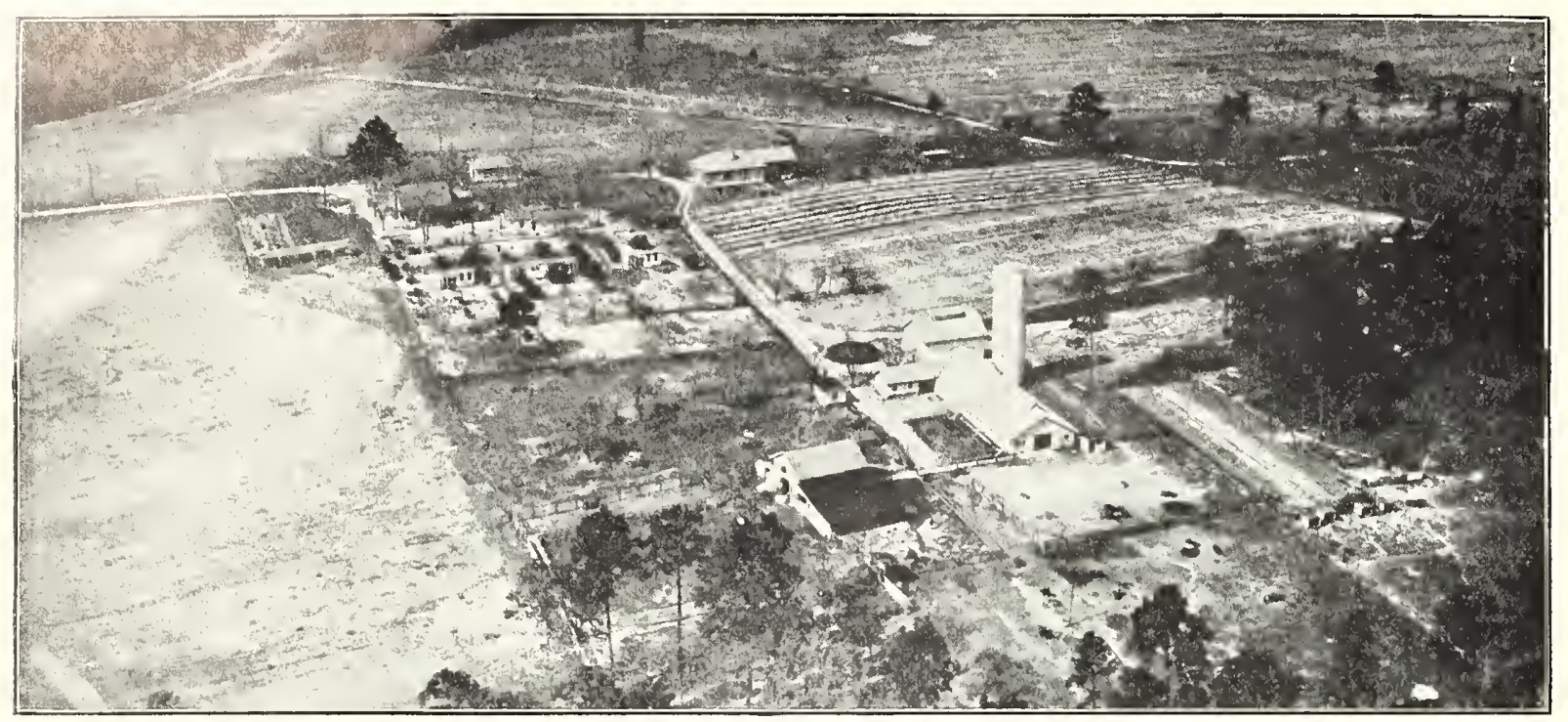

\section{DO YOU KNOW WHAT TO PLANT EACH MONTH?}

\section{Van Antwerp's Monthly Planting Calendar BE SURE TO READ THIS PAGE OVER, IT WILL HELP YOU IN PLANNING YOUR GARDEN}

\begin{abstract}
Vegetables-During this month you can plant Beets,
Carrots, Collards, Endive, Asparagus, Mustard, Spinach, Carrots, Collards, Endive, Asparagus, Mustard, Spinach,
Leek, Turnip, Rutabagas, Parsnips, Radish, Cress, Cher vil, Parsley, Celery for cutting, Peas tor general crop.
Sow Lettuce. Caulifower, Egg Plant, Pepper, Cabbage
and Tomatoes in hotbeds. Sow Herbs of all kinds. Onion Sets and Shallots. Plant Cucumber seed in flowe pots for

Flowers-In open ground plant Sweet Peas, Asters, Chrysanthemums, Columbine, Calliopsis, Candytuft, Daisy nonette, Pansy, Petunia, Pinks, Alyssum and all othe Field-Plant Rust-Proof Oats, Burt Oats, Barley, Clover and Grasses.
Orchard-Set out

Deciduous Fruit and Pecan Trees, and do all pruning necessary. Spray Citrus Fruit trees with Van Ant. Trees with Schnarr's, 1 to 20 . Plant Citrus 'Trifoliata FEBRUARY

Vegetables-All Winter vegetables can be sown this month: Spinach, Mustard, Carrots, Beets, Parsnips,
Leek, Radish, Turnip, Kohl-Rabi, Lettuce, Cabbage,
Onion Sets, Irish Potatoes, Asparagus and Rhubarb All Onion Sets, Irish Potatoes, Asparagus and Rhubarb All
varieties of Peas, also Chervil, Parsley, Cress and Celery
for seasoning. Horse Radish, Asparagus and Rhubarb for seasoning should be set out. Weather permitting, you may plant the latter part of month: Bush Beans, Corn, also matoes, Peppens and Egg Plants in hotbed. For stock should be planted in bed so as to have early slips.
Flowers-Plant same as last month: Nasturtiums, Candytuft, Verbena, Sunflower, Sensitive Plant, Sweet Peas, Phlox, Pansy, etc. Bulbs of Tuberose, Gladiolus,
Dahlia, Canna, Begonia, Amaryllis and Gloxinia inside.
Field-Continue planting Burt Oats, Barley, Canada Field Peas, Johnson Grass, and all other Summer grasses ind clov

Orchard-Set out Grape Vine, Fruit and Ornamental evergreen trees and shrubs this month.
\end{abstract}

$\mathrm{MARCH}$

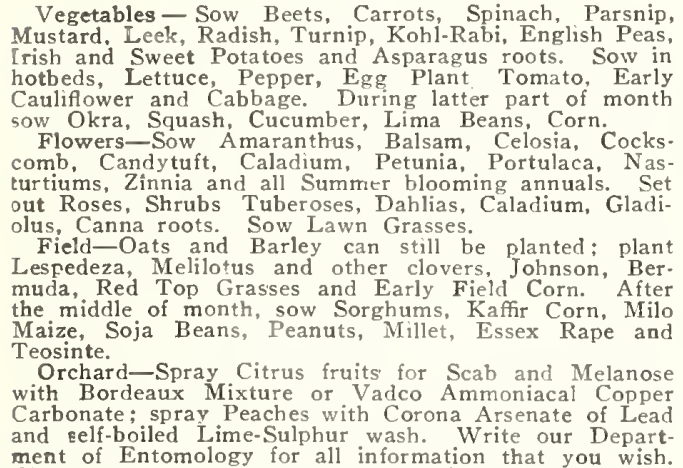

Vegetables-Plant all varieties, Bush, Pole, Butter and Lima Beans, Peas, Squash, Cucumber, Okra, CantaRadish, Pepper, Herbs, Egg Plant, Mustard, Turnip, Beets, Carrots, Flowers-Plant Zinnia, Balsam, Princess Feathers and ll other Summer blooming annuals. Set out Chrysan themums, Pansy, Salvia, Coleus plants and all other and all other Summer blooming roots. Field-Sow Pearl and German Millets, Sorghums, and Lyon Beans, Cotton, Corn, Beggar Weed, Cowpeas, rasses, Clovers, Essex Rape and Sweet Potato plants. Orchard-Spray, Citrus fruit with Van Antwerp's Inand Scale Insects. Make another application of fungicide for Scab and Melanose. Make second application of MAY

Vegetables-Pumpkins, Cucumber, Melons, Squash, late varieties of Corn and Irish Potatoes and all vegetable

Flowers-Plant all annuals, as directed, during April. Field-Sow Cowpeas, Peanuts, Sorghum. Soja. Velvet and German Millet, Cotton, Sweet Potato plants, Les. pedeza, Melilotus and Japan Clover, late Field Corn, Orchard-Keep ground clean around trees. Spray Dog. If necessary make another application of fungrcide for Scab and Melanose. If brown or soft Scab is present, spray with Van Antwerp's Insecticide (Schnarr's
Improved), I part to 80 parts of water, to which has been added Whale Oil Soap.

Vegetables-Sowing during this month is similar to the preceding. Tomato, Collards and Cabbage for late Cucumber, Radish, Turnip, Mustard, etc. Flowers-Follow directions as given in April and May. Lyon Beans, Sorghum, Kaffir Corn, Millet, Teosinte,

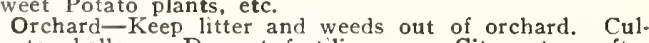
ivate shallow. Do not fertilize your Citrus tree after Antwerp's Insecticide (Schnarr's Improved), 1 part to JULY

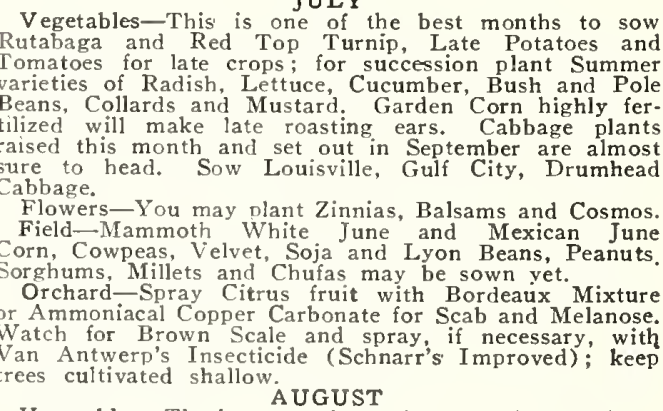

baga for roots. Sow Beets, Bush and Pole Beans, Kale, Kohl-Rabi, Radish, Lettuce, Mustard, Parsler, Endive, and Shallots. We recommend Snowflake Cauliflower as sure header. Celery sown this month for blanching. Flowers-A late planting of Dwarf Nasturtiums may flowers. Sow Balsam Old Maid, Zinnia and all annuals Fied in Spring time for Fall blooming. Orchard-Make last shallow cultivation early part of month of Citrus Trees; spray for Brown Scale, Rust SEPTEMBER

Vegetables-Sow nearly all seed recommended for last This is the proper month to begin sowin may plant English Peas. Later part of month you Flowers-Sow Aster, Carnation, Calendula, Candy tuft Stocks, Sweet Pea seed, Freesia, Narcissus, Hyacinth and Lily Bulbs. Sow your lawn this month. Field-Sow Crimson, Red, Burr and other Clovers,
Essex Rape, Oats Rye, Wheat, Barley and Vetch. Orchard-Spray with Van Antwerp's Insecticide 80. Cover new growth with Bordeaux Mixture to pre vent Scab infection. Spray for Rust Mites and Red Spider. Begin planting your Citrus Trifoliata seed. OCTOBER

Vegetables-Set out Shallots, Garlic and Onion Sets Endive, Leek, Kohl.Rabi, Mustard, Onion Seed, Parsley, Salisfy, Parsnips, Radist, Spinach, Turnips, Rutabagas, Peas. Set out Lettuce, Cabbage and Collard plants. About the middle of the month, sow Succession and Early Summer Cabbage seed for Spring crop. Salsify does best sown this month. Daisies, Petunia, Pansies, Candytuft, Poppy and Pinks, nuals recommended last month. Field-Sow Crimson, Burr and other Clovers, Hairy
Vetch, Essex Rape, Alfalfa, Oats, Rye, Wheat and Orchard-Spray with Van Antwerp's Insecticide (Schnarr's Improved) for Scale insects. This spray will also remove sooty mold from leaves and fruit. phur for Rust Mites and Red Spider.

NOVEMBER

Vegetables-Sow Turnip, Kale and Mustard for salad, early and late English Peas; continue to put out Onion Sets, also Cabbage, Lettuce, Collards and Strawberry plants. Sow Lettuce and early Cabbage seed in cold Flowers-Sow Sweet Peas and all annuals recommended last month. Continue to set out bulbs. Plant Field-Oats Rye, Essex Rape, Vetch, Clovers, Bar ey, Wheat and Grasses. Canada Field Peas may b wn this mont

cover crop of Burr or Crimson werp's Insecticide (Schnarr's Improved) with Van AntWhite Fly and Scale insects. Plant Citrus Trifoliata Vegetables-A DECEMBER

Vegetables-A general crop of Peas, the Black-Eyed Marrowfat should be planted. Put ouf Horseradish, Asparagus and Rhubarb roots, Cabbage and Strawberr plants. Sow in hotbeds, Lettuce, Cabbage, Cauliflower, plant Onion plants.

Follow the above Planting Calendar-it will assist you. Write our "Service Department"-it is at your disposal for any further information you may desire. 


\section{$\$ 200$ o0 \\ IN \\ PHOTO CONTEST $\$ 100.00$ IN PRIZES}

FOR 1928

Take or have a friend of yours take a photograph of your VAN ANTWERP GARDEN any time before September 15th, 1928, and mail it to us marked for PHOTO CONTEST. Write your fuil name and address on the back of the photo, also the names of the people shown in the photo. All customers of Van Antwerp's Seed Store who order from this catalog by mail can enter photos in this contest. The customer who orders just a few ten cent packages of seeds will have just the same opportunity to win one of the $19 \mathrm{CASH}$ PRIZES as the largest buyer.

\section{CASH PRIZES FOR BEST PHOTOS}

\begin{tabular}{|c|c|}
\hline 1st Prize $\ldots \ldots \ldots \ldots \ldots \ldots \ldots$ & 25.00 \\
\hline 2nd Prize & 15.00 \\
\hline 3rd Prize $\ldots \ldots \ldots \ldots \ldots \ldots$ & 10.00 \\
\hline 9 Fourth Prizes, $\$ 4.00$ Each....... & 36.00 \\
\hline 7 Fifth Prizes, $\$ 2.00$ Each........ & 14.00 \\
\hline
\end{tabular}

All photos must reach us on or before September 15th, 1928, and they will become our property for exclusive reproduction. Checks will be mailed the 19 winners on October 1st, 1928. Be sure to send at least one photo of your garden.

\section{LETTER CONTEST $\$ 100.00$ IN PRIZES}

\section{FOR 1928}

This letter contest is open to all mail order customers ANTWERP'S who order from this seed catalog. The rules are ver: simple. All you have to do is write us a letter telling us of the benefits and results obtained by using VAN ANTWERP'S SEEDS and what our seeds have done for you. Write your letter so it will not exceed one hundred words also your full name and address at the end of your letter. All letters to reach us on or before September 15th, 1928. The small customer will have just the same opportunity to win one of the 17 cash prizes in this letter contest as the large buyer.

\section{CASH PRIZES \\ FOR BEST LETTERS}

\begin{tabular}{|c|c|}
\hline 1st Prize $\ldots \ldots \ldots \ldots \ldots \ldots \ldots \ldots$ & 30.00 \\
\hline 2nd Prize & 20.00 \\
\hline 3rd Prize $\ldots \ldots \ldots \ldots \ldots \ldots \ldots$ & 10.00 \\
\hline 4 Fourth Prizes, $\$ 5.00$ Each....... & 20.00 \\
\hline 10 Fifth Prizes, $\$ 2.00$ Each. . . . . . & 20.00 \\
\hline
\end{tabular}

Remember all letters to reach us not later than September 15th, 1928. They will become our property for exclusive reproduction. Checks will be mailed the winners on October 1st, 1928, and the names of the winners announced in our 1929 catalog.

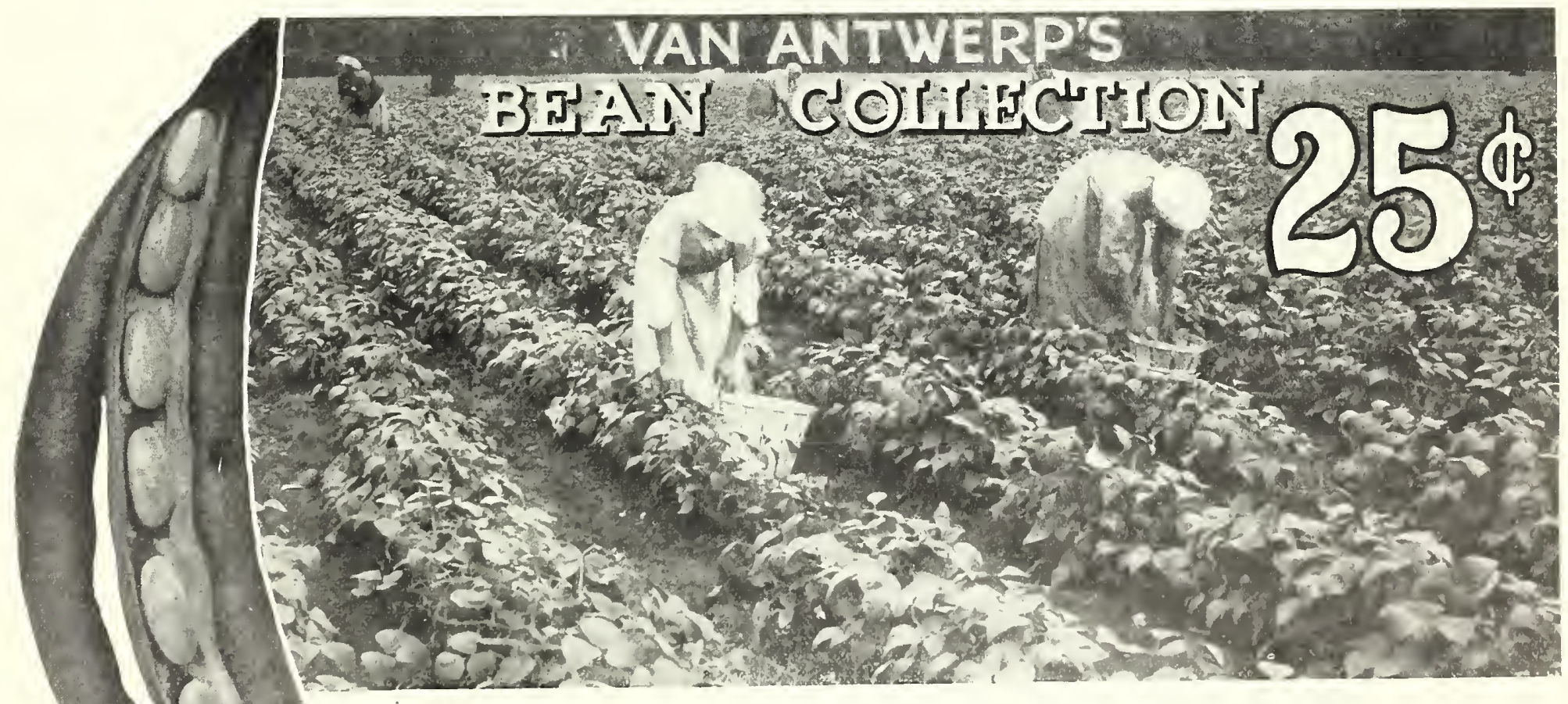

BEST 4 SNAP BEAN COLLECTION NO. 5

3 Full Packets Bush Beans-1 Full Packet Pole Beans

For $25 \mathrm{c}$ we will send you 4 full packets of the best 4-snap Beans. You get 1 packet Burpee's stringless, 1 packet Red Valentine, 1 packet Improved Golden Wax and 1 packet Kentucky Wonder Pole Snap Beans.

All new crop beans. The 4 packets value $40 \mathrm{c}$ for $25 \mathrm{c}$ postpaid.

Order Collection No. 5 and send only $25 \mathrm{c}$ 

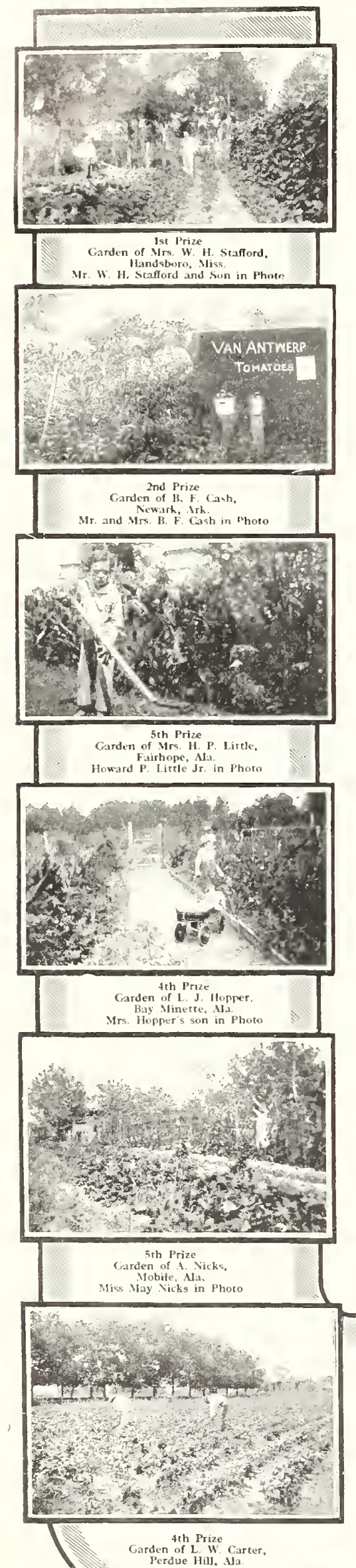

\section{PRIZE WINNERS}

IN LAST YEAR'S

\section{PHOTO CONTEST}

Here are the Gardens of the 14 CASH PRIZE WINNERS in last year's I an Antwerp's I'hoto Contest. Under each photo we print the names and addresses of the owners of each Prize Vinning Garden. These photos have of course been greatly reduced so as to fit in this catalog page. The original photos were larger and clearer than these reproductions.

The photos on this page prove conclusively that it pays to plant VAN ANTWERP'S SEEDS, For over 50 years Van Antwerp's have supplied the South's leading market gardeners and home gardeners with Seeds, Bulbs and Plants. Jun are assured of a crop when you sow Tan Antwerp's Tested Seeds. We are one of the South's Oldest and Largest Mail Order Seed Houses.

\section{TWO BIG PRIZE CONTESTS FOR 1928}

On page 5 of this book you will find VAN ANTWERP'S 2 BIG PRIZE CONTESTS for 1928. We are giving $\$ 100.00$ in Cash Prizes for Garden Photos and another $\$ 100.00$ in Cash Prizes for Letters. Full particulars of these 2 BIG CONTESTS will be found on page 5. Be sure to look at it NOW.
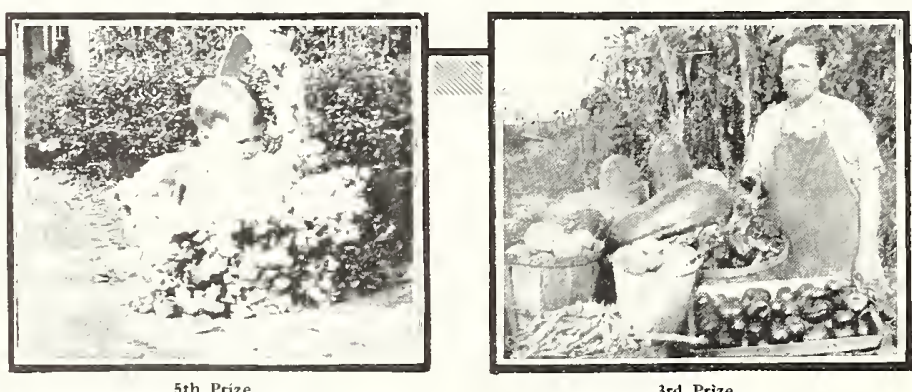

5th Prize
Garden of P. M. Angle,
Kentucky St., Mobile, Ala.
Baby Miriam Angle in Photo

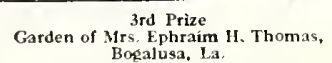
Mrs. E, P. Thomas in Photo
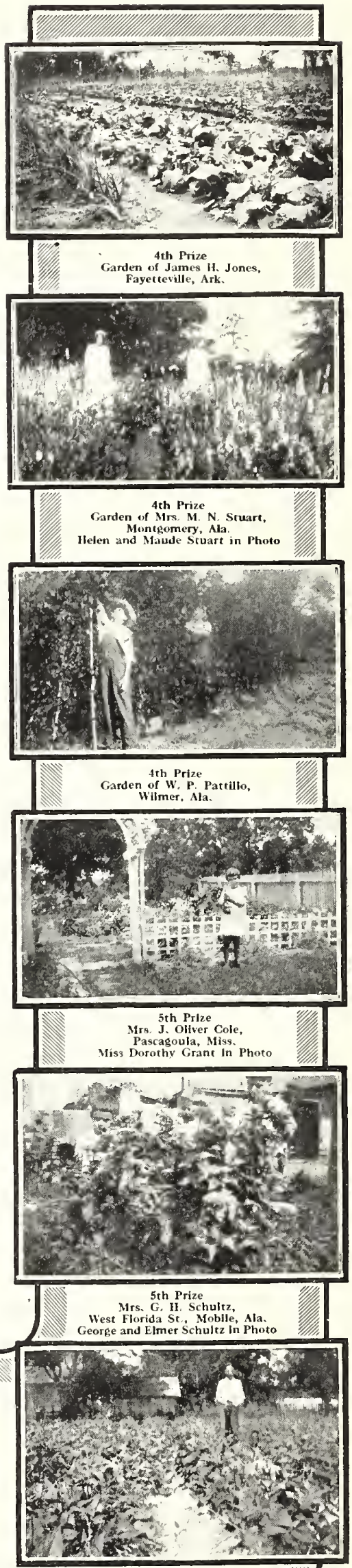

4th Prize
Garden of Miss Rhoda Bond,
Perkinston, Miss. 


\section{P R E M I U M S \\ For All Van Antwerp's Customers}

\section{READ THIS}

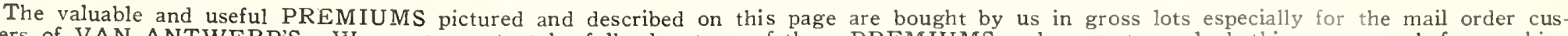

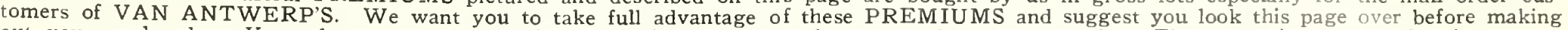

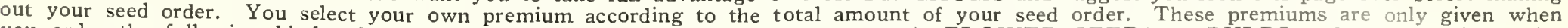

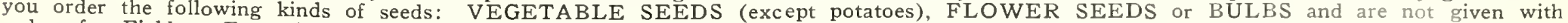

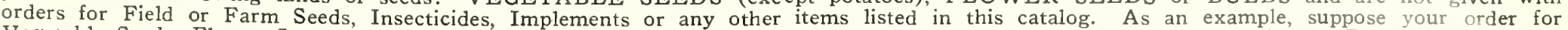

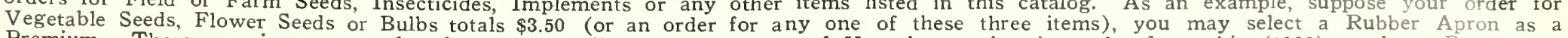

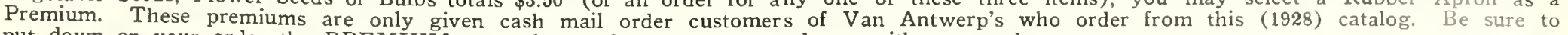
put down on your order the PREMIUM you select and want us to send you with your order.

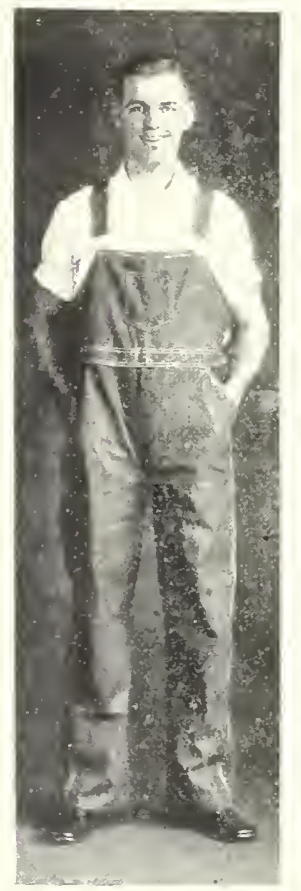

A $\$ 10.00$ Order and These $\$ 1.50$ Overalls Are Yours Free 38,40 and 42 inches.

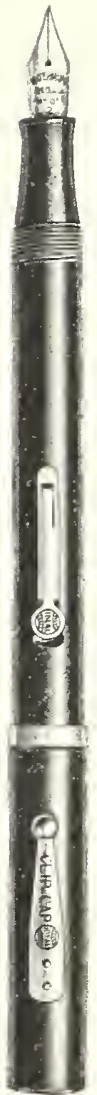

\section{Select the Premium You Want \\ OVERALLS \\ Best Southern Made \\ APRONS \\ Pure Rubber}

The OVERALLS illustrated on this page are made by one of the largest Southern Overall Factories. They are cut from GENUINE INDIGO DYED 2.20 White Back Denim. Al the main seams are triple stitched throughout: the very highest grade loops and slides are used. All points at which a strain is placed are bar tacked to prevent ripping. This gar ment throughout is considered as one of the best on the market and will give you splendid wear. Every farmer or home gardener can use a pair of these serviceable overalls. The price usually charged by the leading stores for this pair of overalls is \$1.50. If your order for Vegetable Seeds, Flower Seeds or Bulbs (not including Field Seeds or other articles) totals $\$ 10.00$ you may select a pair of these overalls FREE. Be sure to put down on your order the size overalls you wear. We have the following sizes (waist measurements) $32,34,36$,

\section{FOUNTAIN PENS}

\section{Genuine Waterman}

The No. 52 GENTLEMEN'S WATERMAN IDEAL FOUNTAIN PEN illustrated on this page is made of hard rubber. It is the favorite self filler design, nickel trimmed and comes in plain or chased design. Has a very nobby clip cap and can be easily carried in the pocket or used on your desk or writing table. This is a very serviceable pen and is the style of pen used by business and professional men all over the world. This pen is guaranteed to be made and sold by the $\mathrm{T}$. E. Waterman Company at their New York City store for $\$ 2.75$ each. If your order for Vegetable Seeds, Flower Seeds or Bulbs total $\$ 15.00$ you may select one of these pens as a premium. They are not given with Field seeds or other articles.

No. $52 \frac{1}{2}$ V. LADIES' WATERMAN IDEAL FOUNTAIN PEN is made exactly the same as the gentlemen's pen described above, except it is fitted with ring style cap instead of clip cap. See illustration. This is one of the most popular pens made and is guaranteed to be made and sold by the L. E. Waterman Co. at their New York City Store for $\$ 2.75$.

\section{A $\$ 15.00$ Order Entitles You to One of These Pens Free}

These beautiful TEA APRONS are serviceable and attractive in appearance. They are made of soft gum rubber, daintily trimmed and with heart shaped pocket. Every housewife should own one of these lovely aprons and they are sufficiently attractive to wear while serving guests. The apron is $27 \times 36$ inches in size and comes in pretty pastel shades. The illustration on this page is an exact reproduction of the apron we send you. The leading stores sell these aprons for $\$ 1.00$ each. We send it to you absolutely FREE with an order for $\$ 3.50$ worth of seeds. Remenber, it is only given with Vegetable Seeds, Flower Seeds or Bulb orders (not field seeds or other articles).

A $\$ 3.50$ Order for Seeds and You May Select One of These Aprons Free
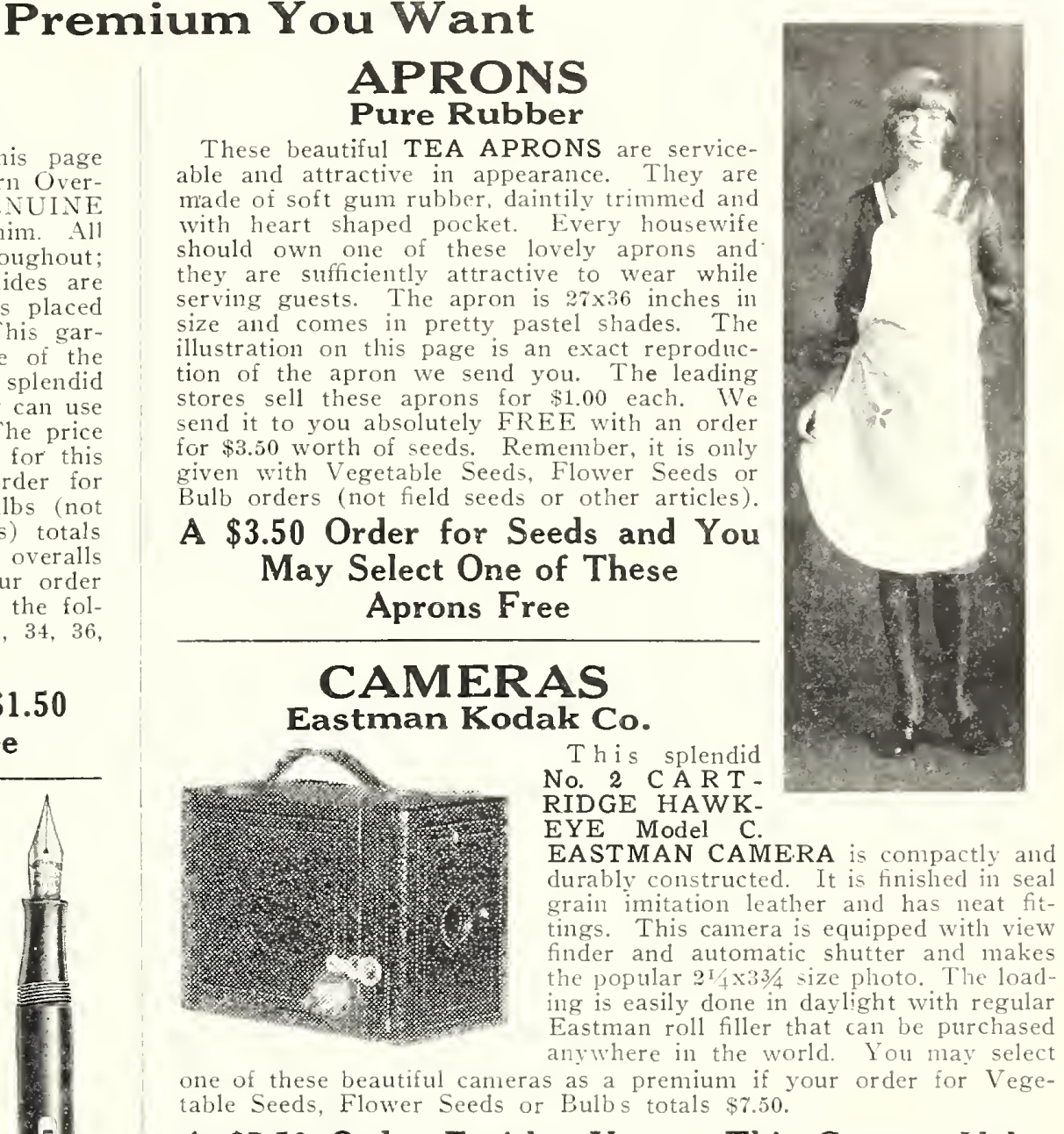

table Seeds, Flower Seeds or Bulbs totals $\$ 7.50$. A $\$ 7.50$ Order Entitles You to This Camera Value
$\$ 1.25$ Free

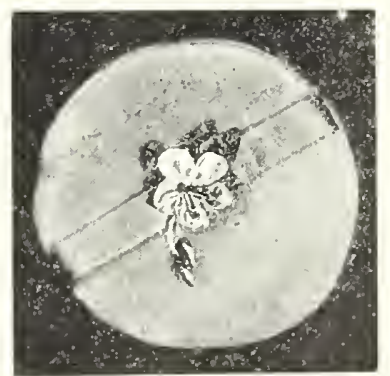

\section{POWDER PUFFS} Velvet Velour

A hand decorated VELVET VELOUR POWDER PUFF est pastel shades. It is attractive in appearance and in addition a very serviceable article. The leading shops sell thi puff for $50 \mathrm{c}$. TVe send it to you exactly as illustrated on this page with an order
for $\$ 2.00$. It is given when you order Vegetable Seeds, Flower Seeds or Bulbs and is not given with field seed orders

A \$2.00 Order Entitles You to This Lovely Powder Puff Free

\section{Special Notice}

The Premiums shown on this page are only given with mail orders for VEGETABLE SEEDS (except potatoes), FLOWER SEEDS or BULBS. Remember, they are not
given with orders sent us for Seed Potatoes, Field or Farm Seeds, Fertilizers, Insecticides, Implements, Plants, Poultry Feeds or Supplies, etc. Our FREE FLOWER SEEDS as shown on the inside Front Cover of Style No. 52 this catalog will also be given with all orders for 50c or over. OUR PROFIT-SHARING CERTIFICATES SHOWN ON

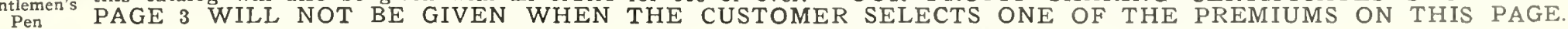
THESE PREMIUMS MUST BE ASKED FOR AT TIME OF ORDERING 


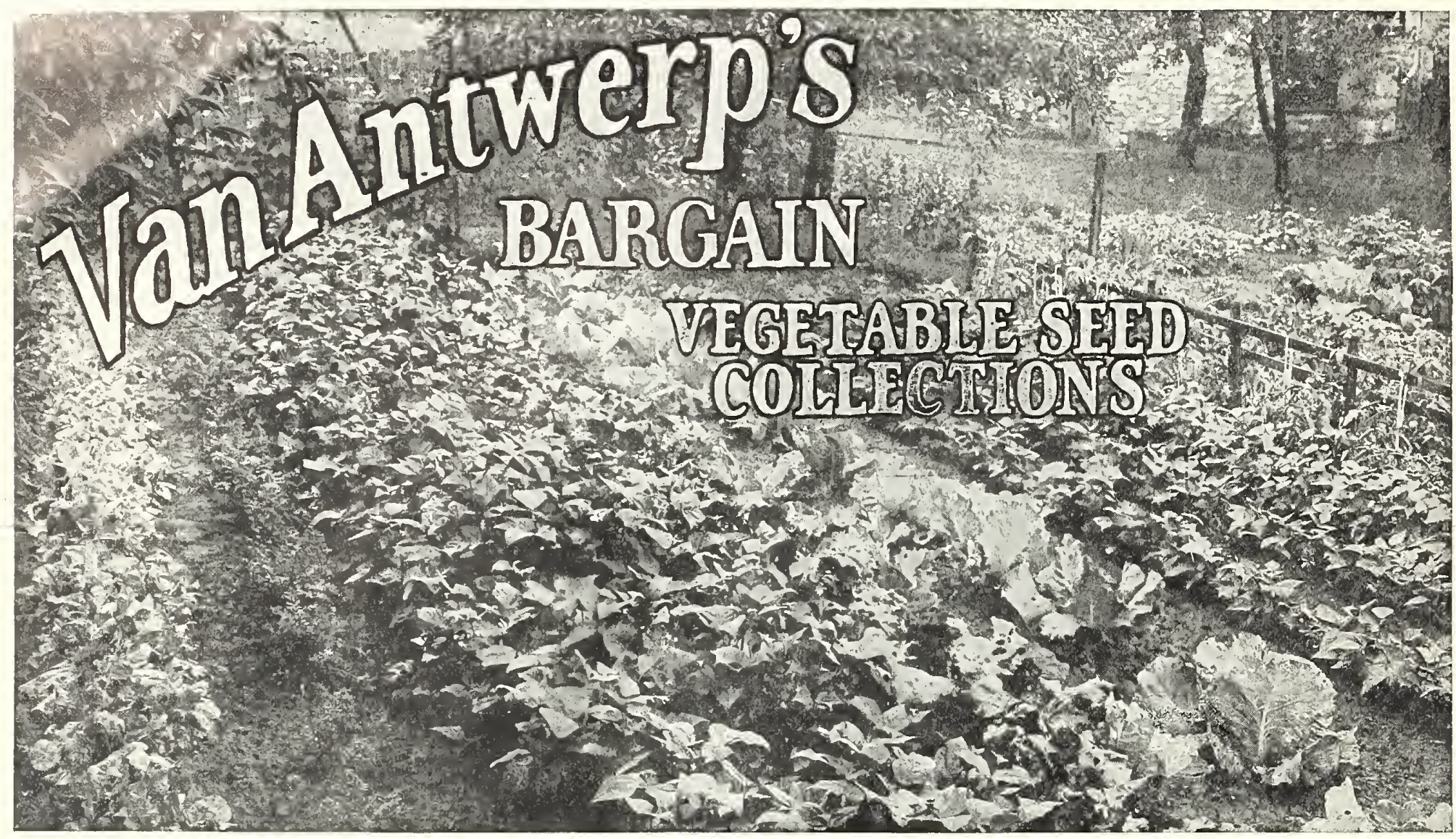

\section{A GARDEN FULL OF VEGETABLES}

15 Big Packets New Crop Seeds.

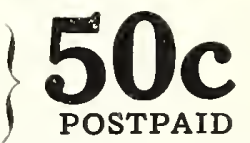

Van Antwerp's have made it possible for everyone with even a little garden space to enjoy a Home Garden and have fresh vegetables by making this liberal offer of 15 packets of strictly fresh vegetable seeds for 50c. Bought from this catalog separately the 15 packets would cost you $\$ 1.15$. Send only 50c for this collection and we guarantee safe delivery.

1 Packet Mobile Market Beets

1 Packet Stringless Beans

1 Packet Danvers Half-Long Carrot

1 Packet White Spine Cucumbers

Packet Emerald Gem Cantaloupe
1 Packet Georgia Collards

1 Packet Big Boston Lettuce

1 Packet Southern Curled Mustard

1 Packet White Velvet Okra
1 Packet Red Globe Radish

1 Packet Early White Bush Squash

1 Packet Earliana Tomato

1 Packet White Globe Turnip

1 Packet Tom Watson Watermelon

For $50 \mathrm{c}$ we will send you the above collection of vegetables ( 15 varieties) postpaid. No changes will be allowed in this collection and no others will be sold at this reduced price. Order collection No. 1 . Send only $50 \mathrm{c}$ for this No. 1 collection.

\section{BIG BARGAIN VEGETABLE COLLECTION}

35 Packets, Ounces and Half-Pounds-35 Varieties.

\section{$\$ 2.00$}

Look over what you get in this BIG BARGAIN COLLECTION of 35 choice varieties of vegetable seeds, consisting of halfpounds, ounces and packets.

The complete collection of 35 all for $\$ 2.00$, postpaid to your home. Bought separately this collection would cost you $\$ 3.50$.

$1 / 2$ Pound Stringless Green Pod Beans

1 Packet Kentucky Wonder Pole Beans

$1 / 2$ Pound Henderson's Bush Butter Beans

1 Packet Carolina Sieva Pole Butter Beans

1 Ounce Southern Market Beets

Packet Eden Gem Cantaloupe

1 Packet Rockford Cantaloupe

1 Packet Half-Long French Carrot

1 Packet Georgia Collards

$1 / 2$ Pound Country Gentlemen Corn

1 Packet Truckers' Favorite Corn

Packet Vadco Wonder Cucumber

collection and no others will be sold at this reduced price. Order collection No. 35.
1 Packet Black Beauty Egg Plant

1 Packet Kale or Borecole

1 Packet Big Boston Lettuce

1 Packet Southern Curled Mustard

1 Packet Dwarf Green Okra

1 Packet Red Creole Onions

1 Packet Hollow Crown Parsnip

1 Packet Curled Parsley

$1 / 2$ Pound Extra Early Peas

Packet Ruby King Pepper

Ounce Sumpkin, King of Marlot Radish
1 Ounce White-Tipped Scarlet Turnip

Radish

1 Packet White Bush Squash

1 Packet Earliana Tomato

1 Packet Redfield Beauty Tomato

1 Ounce Red Top Turnip

1 Ounce White Globe Turnip

1 Ounce Purple Top Rutabaga

1 Packet Bloomsdale Spinach

1 Ounce Kleckley Sweet Watermelon

Packet Tom Watson Watermelon 


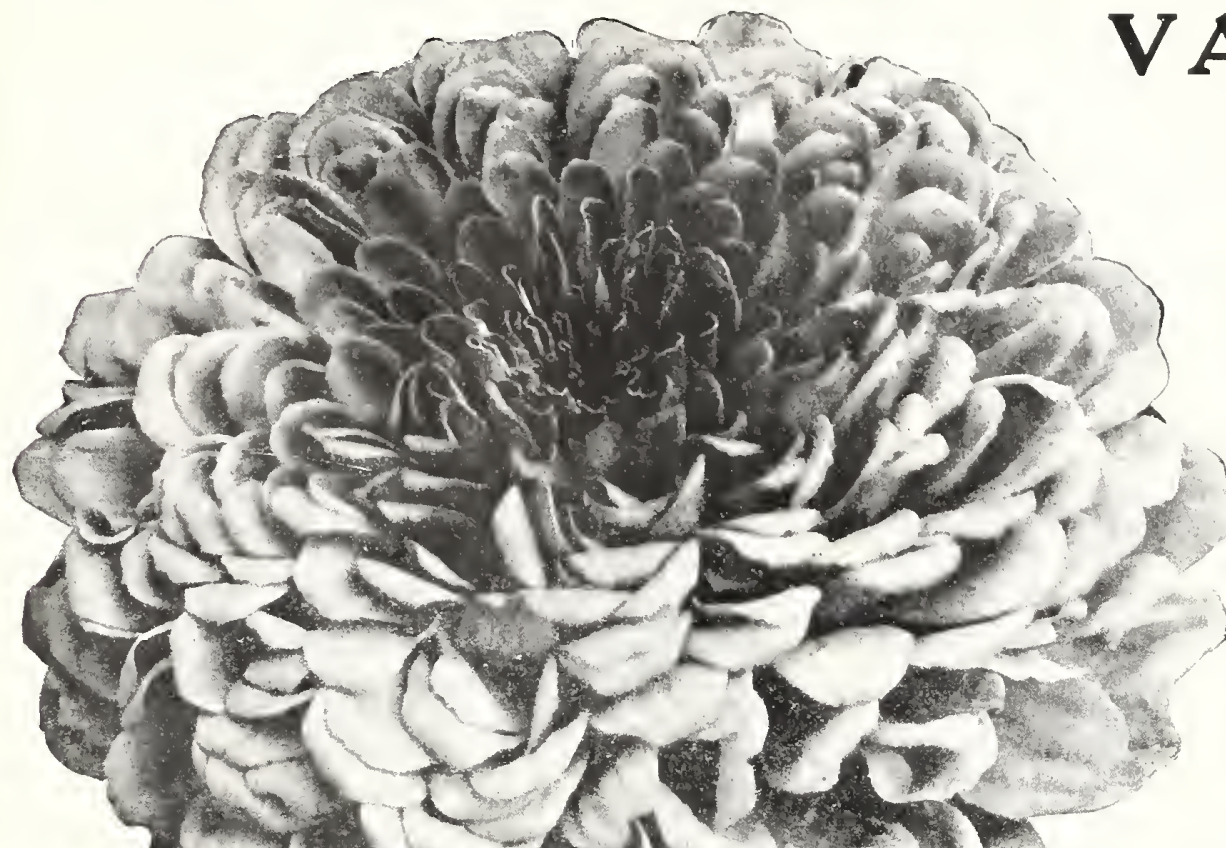

\section{VAN ANTWERP'S \\ Flower Specialties and Novelties for 1928

\author{
WONDERFUL NEW DOUBLE DAHLIA. \\ FLOWERED ZINNIAS
}

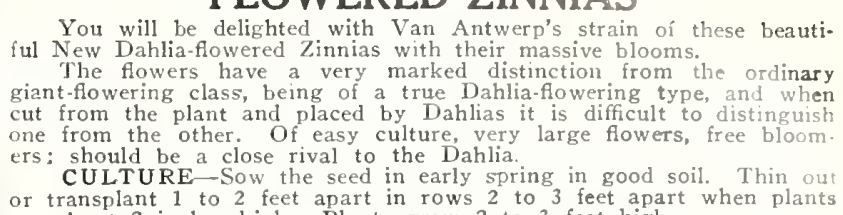

No. 3301-Purple Prince- A lovely new large purple

No. 3302-Illumination- Similar to Exquisite, but a

No. 3303-Salmon Beauty- ${ }_{z i n n i a,}^{A}$ new salmon colored

No. 3304-Exquisite - The flowers resemble a large

No. 3305-Meteor- $\mathrm{A}$ - rich, glowing dee red (Spinel

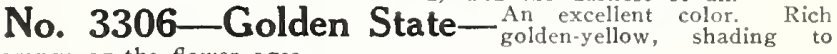

No. 3307-Scarlet Flame- color. $_{\text {cich }}$ orange-scarlet. A most dazzling

No. 3308-Dream - The large flowers are a distinct shade

No. 3309-Polar Bear- nias is decidedly the finest of all white $Z$ in.

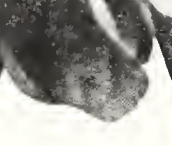

Your choice of any of the above 9 varieties of new Dahlia Zinnias: Price-Anny
of the above varieties of New Dahlia Zinnias, $25 \mathrm{c}$ per pkt.; 2 pkts., $40 \mathrm{co} ; 5$ pkts., $90 \mathrm{cc}$.

No. 3346-Dahlia-Flowered Zinnia Collection, \$1.50-

This collection contains 1 packet each
$Z$ innias. The 9 pkts, for $\$ 1.50$ postpaid.

Our New Dahlia Flowered Zinnia No. 3300 . Photo sent us by our grow-
ers in California. Pkt. 15c; 2 pkts. $25 \mathrm{c}$ in California.
No. 3300 - Vadco New Dahlia Flowered Double Mixed- (See illus.

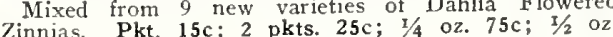
Zinnias. Pkt, $15 c$;

\section{MAMMOTH FLOWERING PHLOX EASY TO GROW AND BLOOM PROFUSELY}

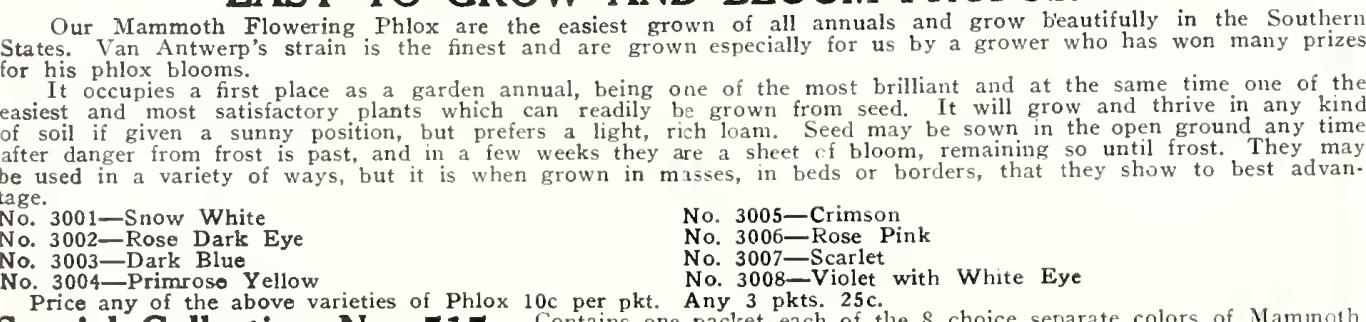

Special Collection No. 515- Contain one packet each or $50 \mathrm{p}$ postpaid.

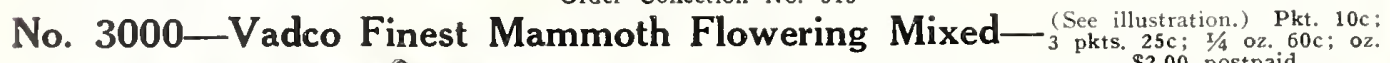

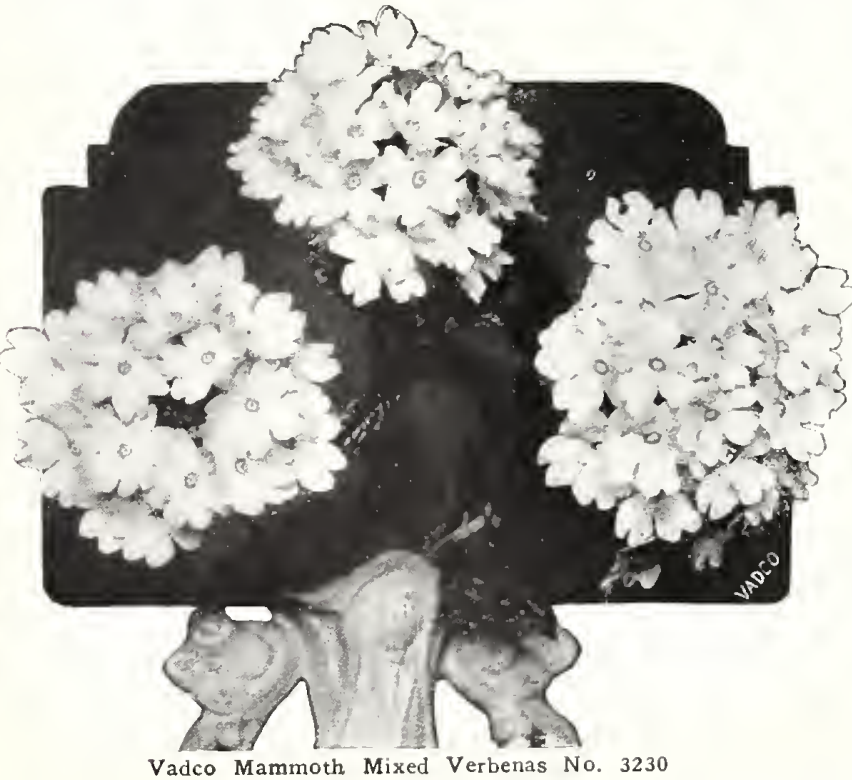

No. 3010 - Star Phlox All colors of the phlox family in starshaped flowers, each petal being pointed. $\$ 2.00$ postpaid.

No. 3020-Hardy Perennial Phlox (Decussata) - $T$ the is is nnial phlox which grows 3 feet high and
comes up every year when planted. Soat

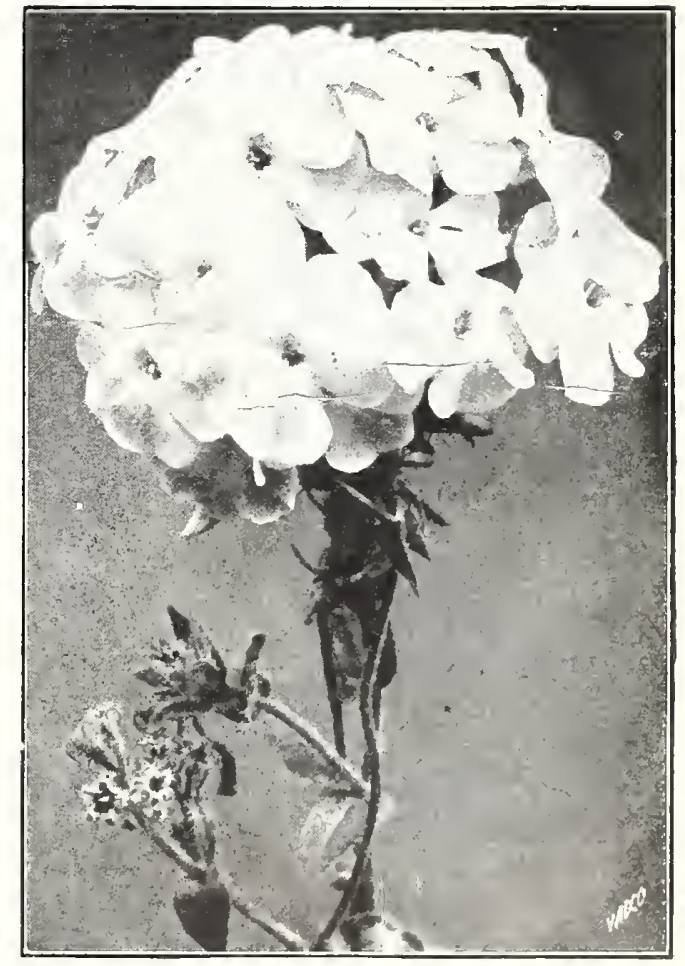

Vadco Mammoth Flowering Phlox No. 3000

\section{MAMMOTH VERBENAS EXTRA SELECTED STRAIN}

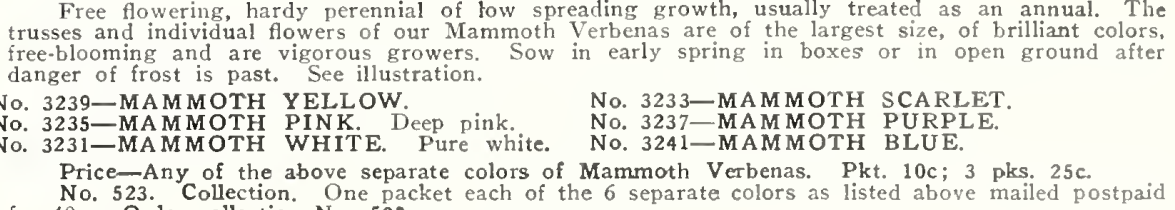

No. 3230 -Vadco Mammoth Mixed- 


\section{VAN ANTWERP'S FLOWER SPECIALTIES AND NOVELTIES FOR 1928}
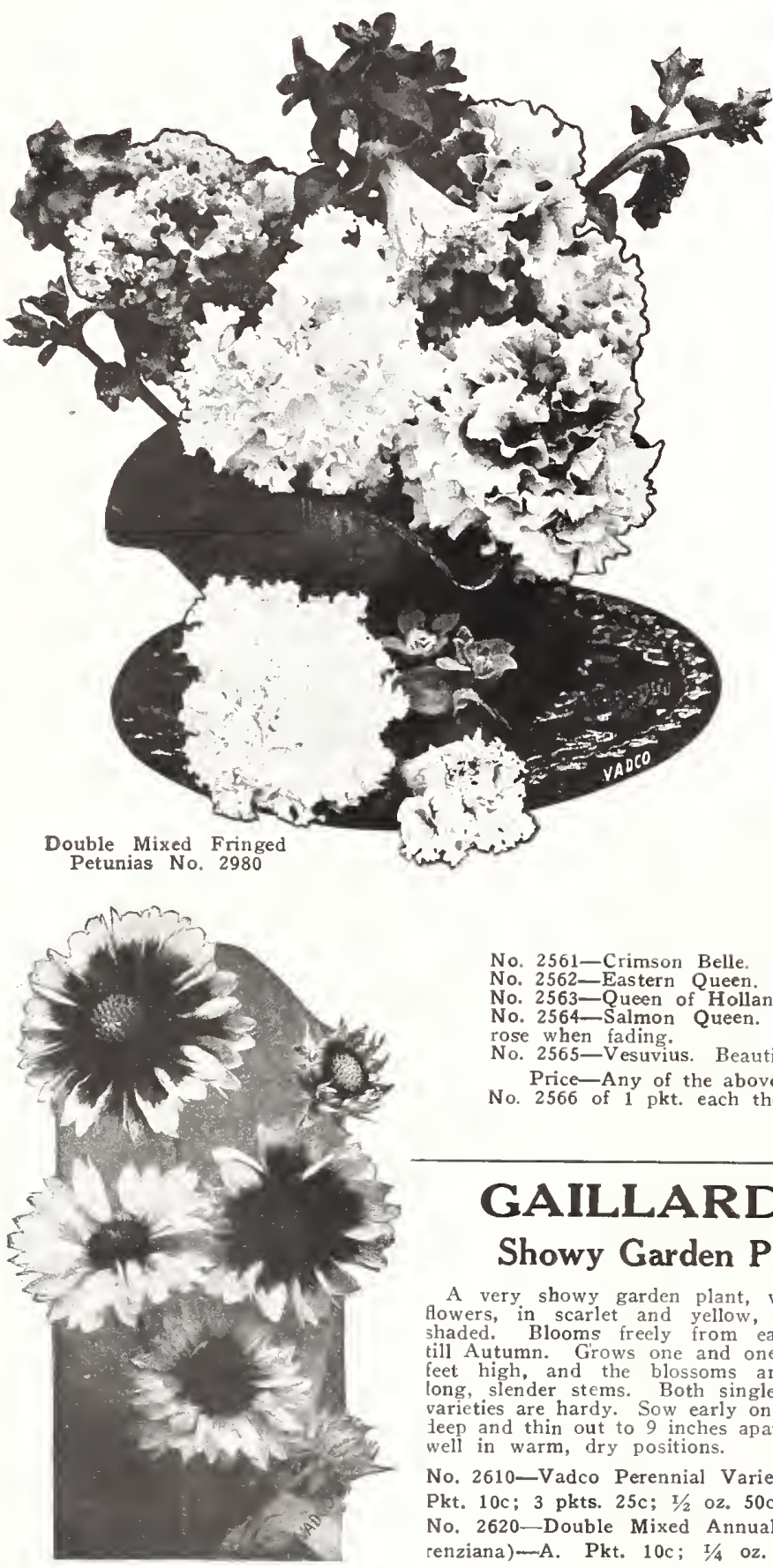

Gaillardia No. 2610

\section{SHASTA DAISY}

Shasta Daisies are easy to grow and do well in every garden. The strain we offer produces extra large blooms on long stems. A splendid cut flower. Produces magnificent pure white flowers 4 inches or more across, on stems $1 \frac{1}{2}$ to 2 feet in length. The plants, 2 to $21 / 2$ feet in height, are hardy, and flower in profusion. See illustration.

No. 3143-SHASTA DAISY. Price, pkt. $10 \mathrm{c} ; 3$ pkts. $25 \mathrm{c} ; 1 / 4 \mathrm{oz} . \$ 1.00$ postpaid.

\section{PORTULACA OR MOSS ROSE}

Should be sown in every garden. Scarcely any annual in cultivation makes such dazzling display of beauty as a bed of highly colored, many-hued Portulacas. The plants are low-growing and creep along the ground. They thrive well in almost any location and can withstand the hottest summer weather. They love the full sunlight, but the finest flowers are produced the latter part of August and September, when there are heavy dews at night. This is particularly true of the double varieties. Sow the seed thinly early in the spring and keep free from wecds.

No. 3080-Single Mixed Portulacas. Pkt. 10c; 3 pkts. 23c; $I / 40 z, 35 c$ $\mathrm{Na} 3090$-Double Mixed Portulacas. Pkt. $10 \mathrm{c} ; 3$ pkts. $25 \mathrm{c} ; 1 / 4 \mathrm{oz} . \$ 1.00$.

\section{DIGITALIS}

Old Fashioned Border Plant A magnificent immense flower, spikes being particularly attractive when grown among growing subs or as background for lowe especially on the white varieties are indeed Sow one-eighth inch deep in rich fine soil, from Spring to mid-sum

No. 2580-Vadco Prize Mixed. Many shades and markings. Pkt. 10c; 3 pks. 25c; 1/4 oz. 40c; 1 0z. $\$ 1.25$. Digitalis No. 2580
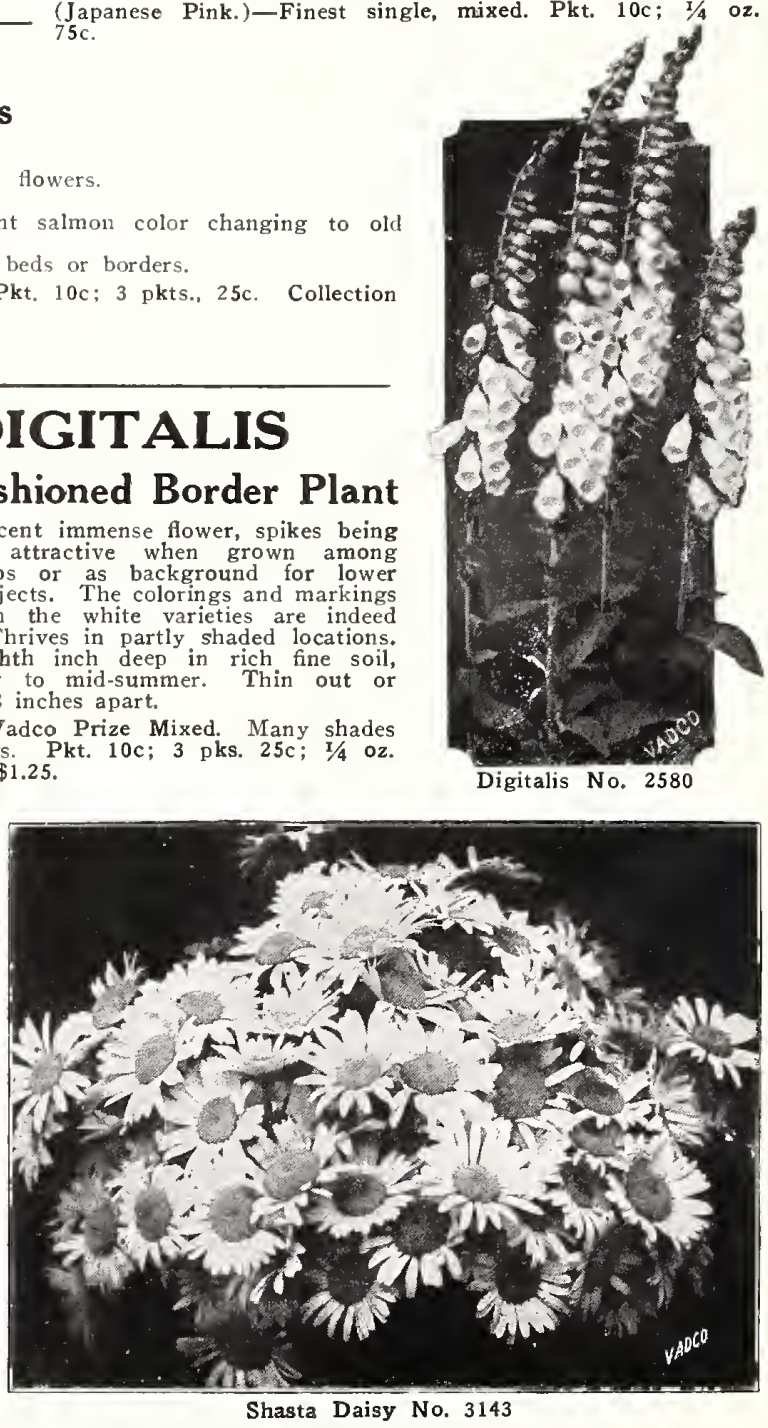


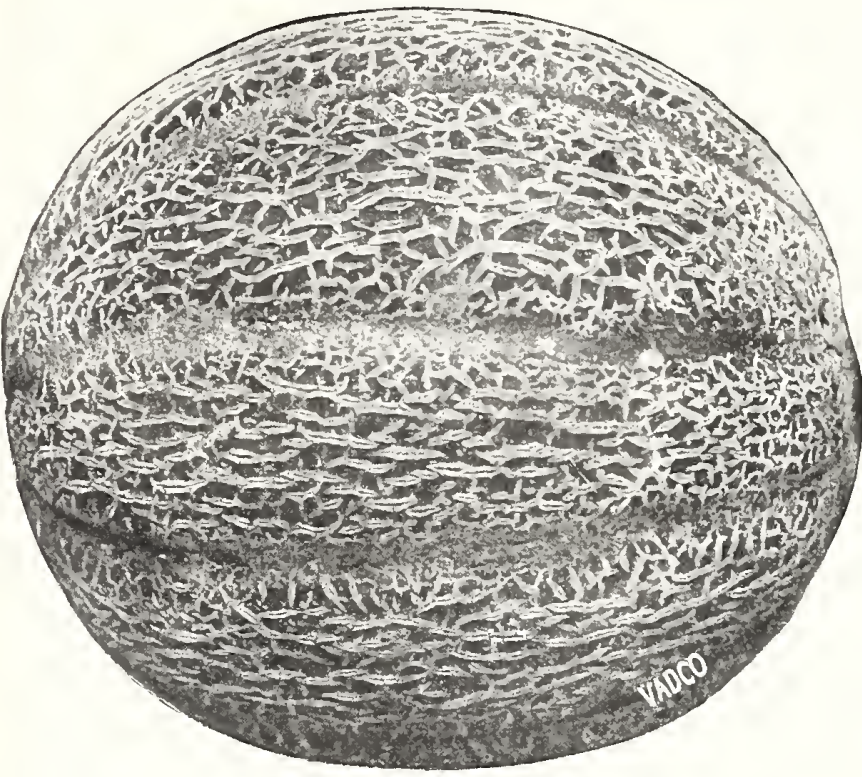

New Mellobite Cantaloupe No. 700
VAN A N T W ERP'S NEW VEGETABLES and Specialties for 1928 MELLOBITE CANTALOUPE No. 700

\section{For Home Gardens or Market}

Mellobite Cantaloupe, which we offered three years ago for the first time under the number netted, with small seed cavity. Mellobite is a very heavy yielder of even sized melons, bearing as many as eleven fine melons on one vine. Mellobi time favorites, Rocky Ford and Eden Gem, ar we received from all over tbe country praising our Mellobite Cantaloupe. Be sure to plant Mellobite this year if you want to taste the sweetest and most delicious melon you have ever Price-NEW CANTALOUPE MELLOBITE No. 700. Pkt. 10c; oz, 20c; $1 / 4$ 1b. $50 \mathrm{c}$. lb. $\$ 1.50 ; 5$ lbs. $\$ 7.00$, postpaid.

We had three other varieties planted and your melon was decidedly the best of all.-R. E. Lambert, Darlington, Ala.

Your New Cantaloupe No. 700 is more than you claim. I have one vine with ten fine DeFuniak Springs, Fla.

Your new melon is the sweetest and best I have ever eaten.-Miss Reba Fuller, Kingston,

\title{
VADCO IMPROVED HALE'S BEST CANTALOUPE, No. 702
}

\author{
A VERY EARLY CANTALOUPE OF WONDERFUL EATING QUALITY
}

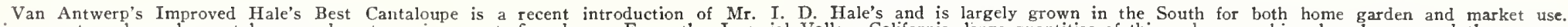

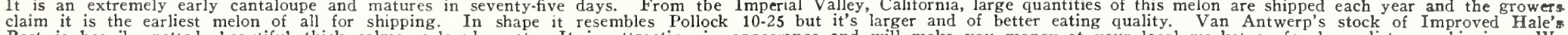

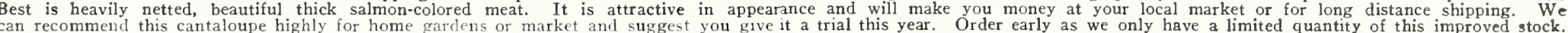
Prices: Van Antwerp's Improved Hale's Best (H. B.) Cantaloupe No. 702-Pkt. 10c; oz. 20c; 1/4 lb. 50c; lb. \$1.50; 5 lbs. \$7.00; 10 lbs. \$13.00, postpaid.

\section{VAN ANTWERP'S NEW CUCUMBER MONEY-MAKER}

IT KEEPS GREEN

Sold Only in Sealed Packages

We are glad to offer large cucumber growers our wonderful New Cucumber "MONEY-MAKER." This is by far the earliest of all the white spine sorts. The fruits to blossom end, and keep green longer than any other variety. It is a vigorous grower, heavy yielder of symmetrical and uniform fruits and has no equal as a shipping variety. Last season we sent bulk samples of this new cucumber to some of the largest growers tried it reported to us and claimed it to be superior to all other cucumbers and a real

\section{EVERY OUNCE OF SEED IS CHEMICALLY TREATED}

We are chemically treating all the seed we sell of our MONEX.MAKER CUCUMBER before sending it out. This special treatment assures you of a stronger stand, resistant to disease attacks and will produce a bigger and better crop than untreated seed. We would like our customers to compare the results obtained with chemically treated and untreated seed. If you plant cucumbers and want the best variety for ship

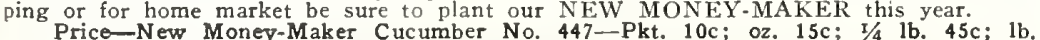
$\$ 1.50 ; 10 \mathrm{lb}$. lots or over at $\$ 1.25$ per lb., postpaid.

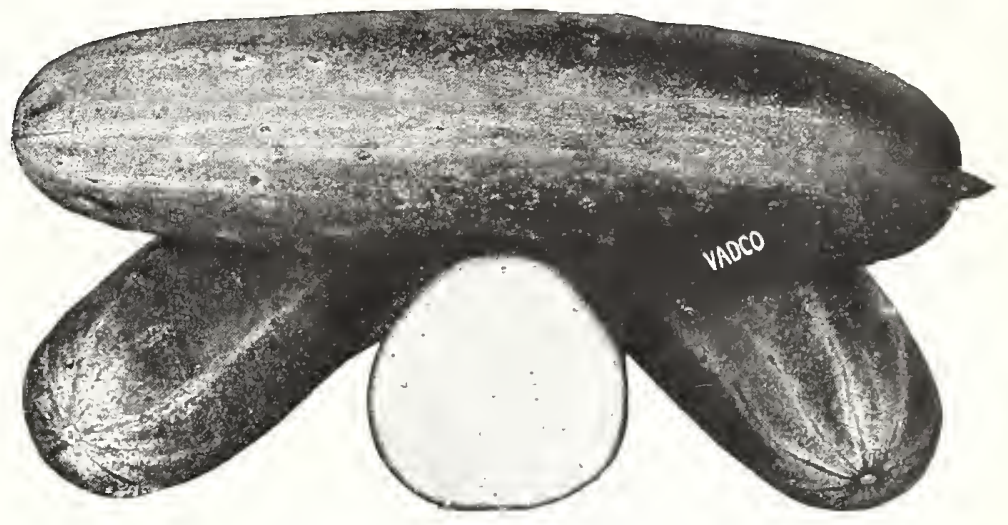

New Cucumber Money-Maker No. 447 It Keeps Green

\section{$\sec 0.0 \%$ (1)}

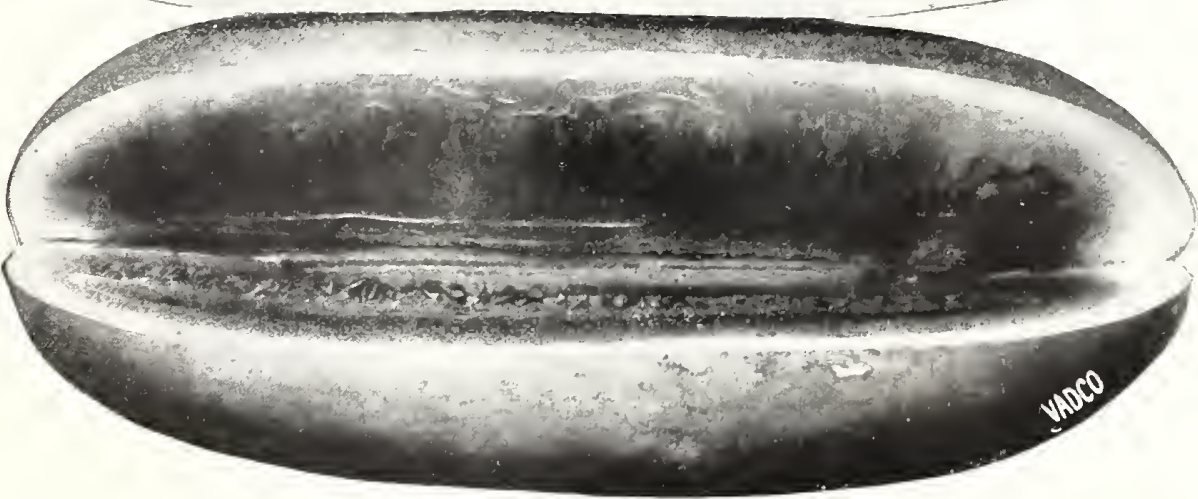

Van Antwerp's New Wondermelon No. 734
NEW WONDERMELON VAN ANTWERP'S TRUE STOCK

For Home Gardens or Market The New Wondermelon has gained in popularity in recent years
and is now planted by many of the large melon growers in the South. resembles the Tom Watson, but is a thicker, more solid and usually larger and heavier. Melons weighing 40 to 50 pounds are not bit of the brilliant red flesh of this melon is sweet to the rind. it is free of cores or hard centers and the rind is thin, yet sufficiently tough to stand ordinary handling. The is thin, a most attractive product for market display. We can strongly recommend this melon but advise intending
planters to be sure and get the true stock direct from Van Ant planters
werp's.

Price-Van Antwerp's True Stock New Wondermelon No 734Pkt. $5 \mathrm{c} ;$ oz. $10 \mathrm{c} ; \mathrm{I} / 4$ lb. $40 \mathrm{c} ; 1 \mathrm{lb} . \$ 1.25 ; 5$ lbs. $\$ 5.00$, postpaid. 


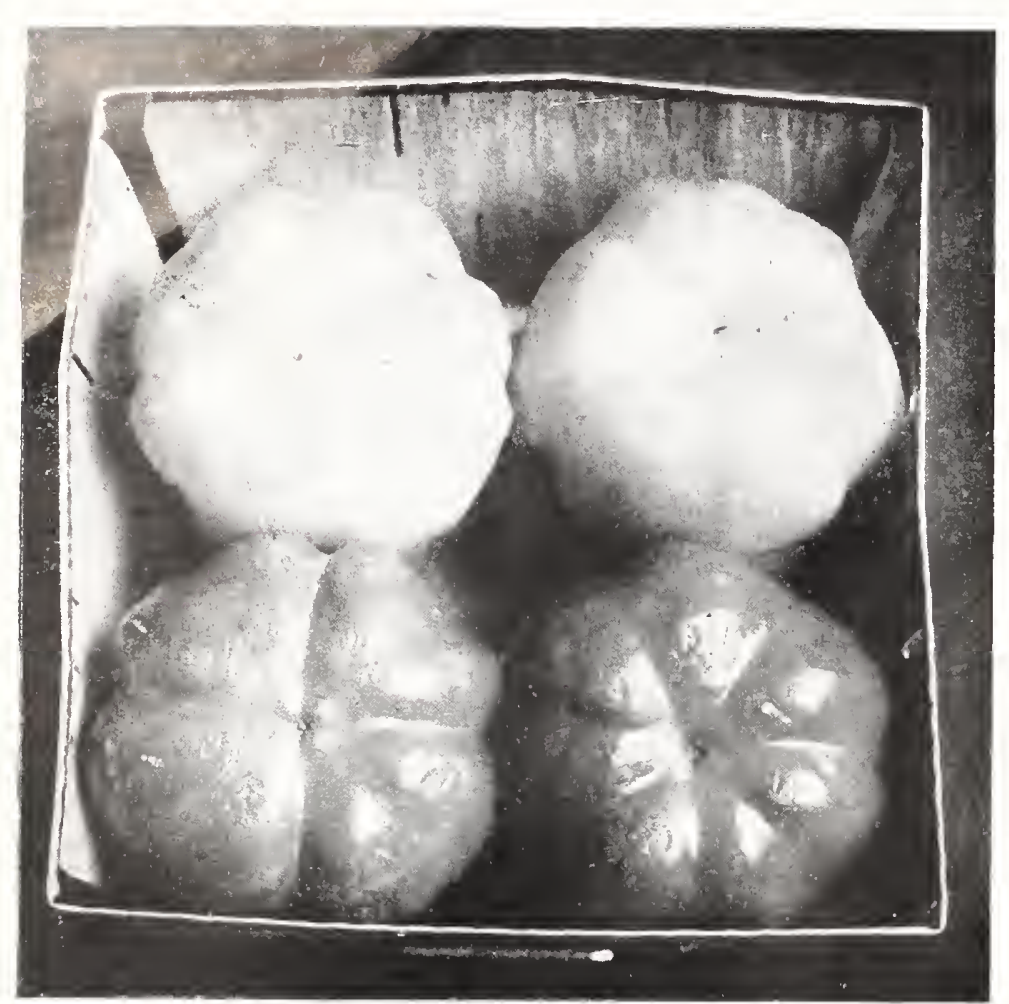

Topepo the World's Newest Vegetable No. 1075

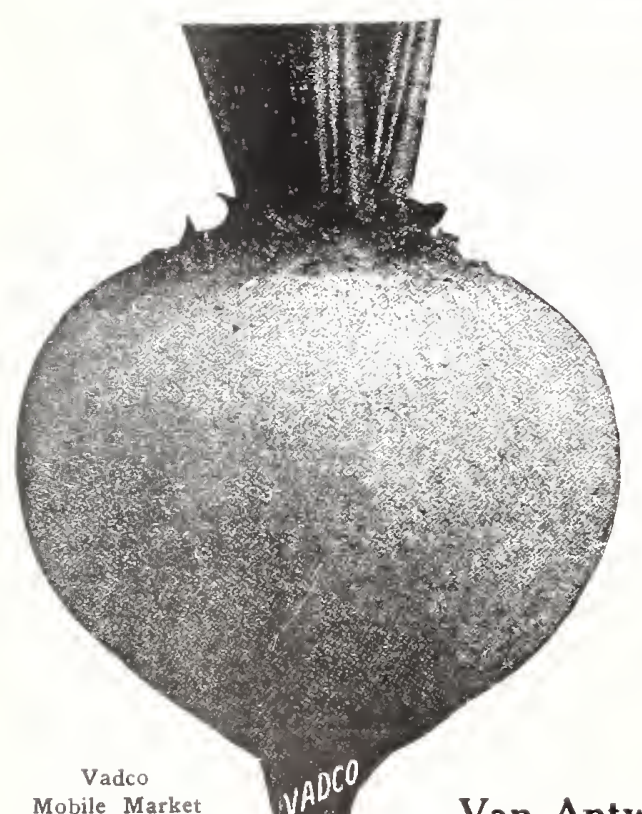

Van Antwerp's New Marglobe Tomato No. 1010 See Colored Illustration on Front Cover

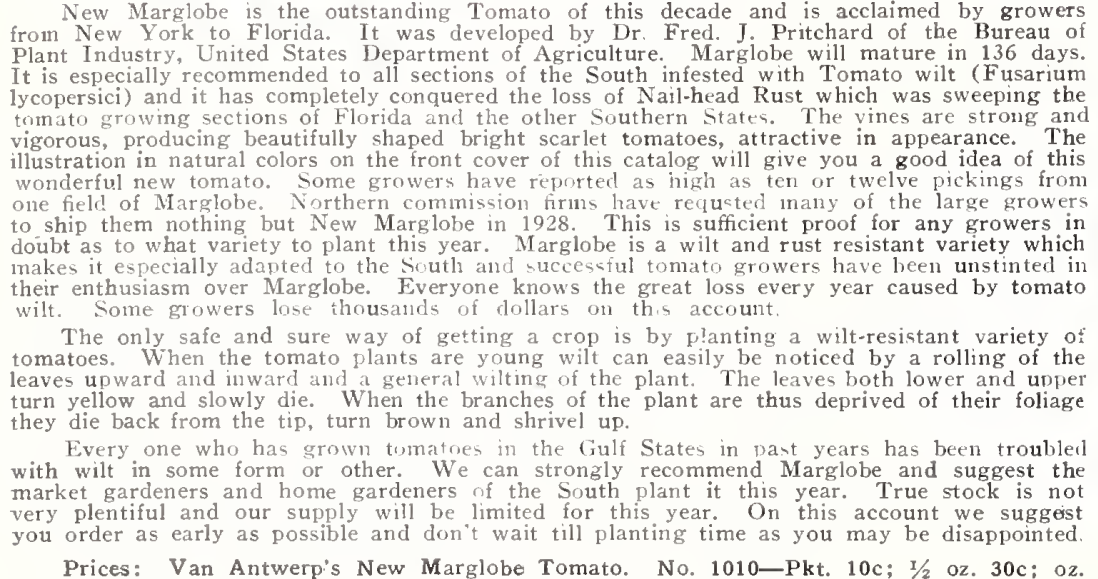

Prices: Van Antwerp's New Marglobe Tomato. No. 1010-Pkt.
; $1 / 4$ lb. $\$ 1.75 ;$ lb. $\$ 6.00 ; 3$ lbs, or over at $\$ 5.00$ per lb. postpaid.

Mobile Market Beet was introduced by us many years ago and is recognized We sell tremendous quantities of this beet every year to the truck farmers of the Gulf States. Please remember that our strain is the original true stock, in shape, for also a medium early sort. They mature in 6 to 7 weeks and are desirable No. 157-Vadco Mobile Market Beet. Price, pkt. 10c; oz. 15c; 1/4 1b. 40c; Ib.

\section{Green Striped Cashaw Pumpkin No. 907}

Vadco True Stock of Green Striped Cashaw Pumpkin is a great favorit among the large commercial growers and thousands of home gardeners in the The fruits are large with crooked neck, the vines hardy and vigorous. The This variety can be private stock and will please the most particular planters. No. 907 -Price, pkt. $5 \mathrm{c} ;$ oz. $15 \mathrm{c} ; 2 / 4 \mathrm{lbs}, 35 \mathrm{c} ; 1 \mathrm{~b} . \$ 1.25 ; 5 \mathrm{lbs} . \$ 6.00,10 \mathrm{lbs} . \$ 10.00$,

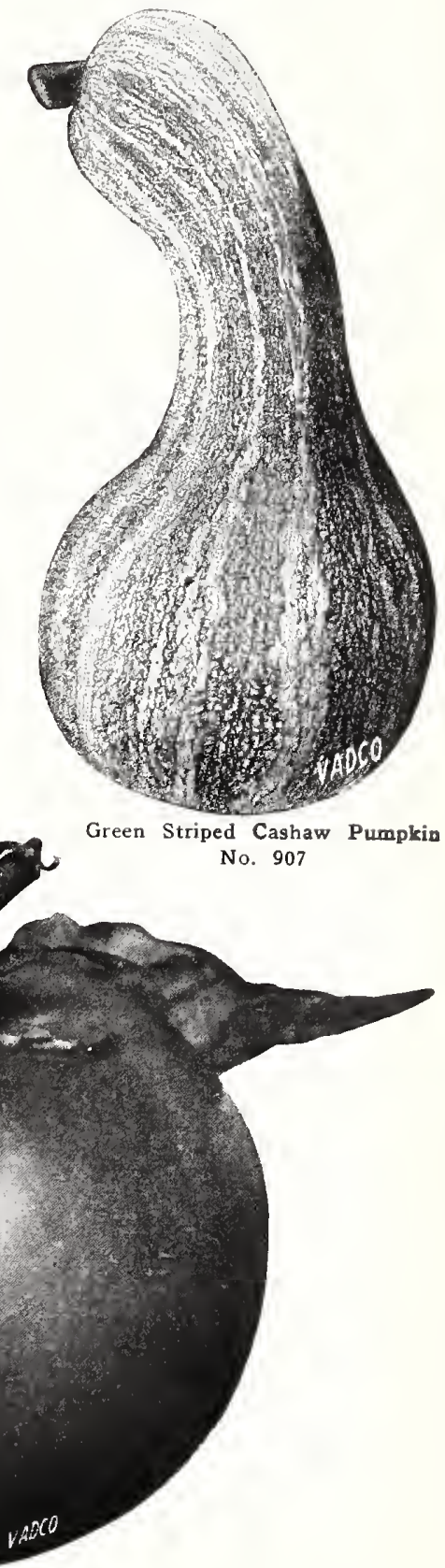

Van Antwerp's New Marglobe Tomato No. 1010 


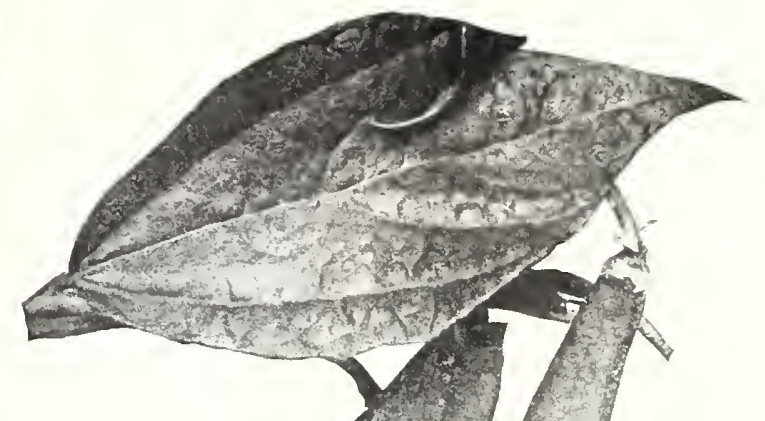

\section{SNAP BEANS $\underset{\substack{\text { ARE EASY } \\ \text { TO GROW }}}{\text { GRO }}$}

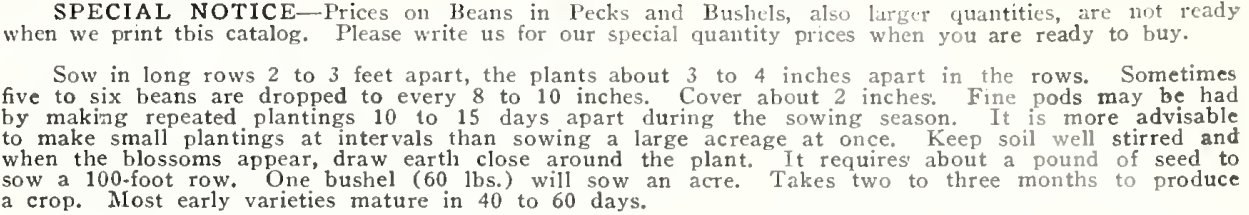

\section{Bush or Bunch Green Podded Varieties}

No. 31-Vadco Extra Early Red Val- $\mid$ No. 23-Burpee's Stringless Green entine, Improved Round Pod- Matures Pod- Matures in 30 to 33 days. One of the earliest. 35 days. The most largely planted variety of bush beans
in the South: a splendid early, heavy-bearing variety, well in the South; a splendid early, heavy-bearing variety, well
adapted to all parts of the South for market or home use. length, curved, cylindrical, with crease in back; very fleshy, crisp and tender. None can compare with our stock of Valentine in fleshiness and high quality of pod. instead of of all Beans on account of pod being curved $20 \mathrm{c} ; 1 \mathrm{~b}$. $35 \mathrm{c} ; 2 \mathrm{lbs}$. $60 \mathrm{c} ; 5 \mathrm{lbs}$. $\$ 1.50$, postpaid. Write for
quantity prices.

No. 21-Black Valentine- Matures in 35 strain of Valentine bean that has steadily made its way into favor as a variety for market gardeners, both for
nearby markets and long distance shipping. Seemingly this bean will stand earlier planting than other varieties bad weather conditions. Extra early, a heavy bearer and holds up splendidly in shipments to Northern paid. Write for quantity prices.

No. 33-Vadco New Green Stringless This magnificent round podded bush bean bears long,
rouno green pods, always solid, stringless and exceedingly rouno green pods, always solid, stringless and exceedingly
prolific. The attractive pods are about five inches long, firm and tender. The plant is of erect growth, witb dark green foliage and practically blight proof. It is a thoryielding a very large crop of handsome green pods that remain for use many days after maturity. Pkt. $10 \mathrm{c} ; \mathrm{I} / 2 \mathrm{lb}$
$25 \mathrm{c} ; 1 \mathrm{~b}$. 50c; 2 lbs. $90 \mathrm{c}$, postpaid. Write for quantity prices.

No. 28-Full-Measure Beans ${ }^{- \text {The Full- }}$ - Feasure rather a new variety as compared to many others, but the straight, round pods - so round they have has light green, are about six inches long, very fleshy and of very fine easily when bent. They come into bearing early, are productive and last a long time. Pkt. $10 \mathrm{c}, 2$ lb. $20 \mathrm{c}$ tity prices.

\section{Bush Wax Beans}

No. 48_-Vadco New Wonder Wax- $\begin{gathered}\text { An entirely new Rustproof } \\ \text { Wax Bean introduce by }\end{gathered}$ Van Antwerp's and offered this year for the first time. The Vadco New Wonder Wax is by fat the best wax bean we have ever seen. It produces beautiful, long, well proportioned pods in profusion. In appearance it resembles the olines are erect, strous The give it a trial. Wo. 54 - Vadco Golden Wax_ Matures in 35 days, One of the large, long and stringles's; For home garden or shipping this Wax Bean has no 作

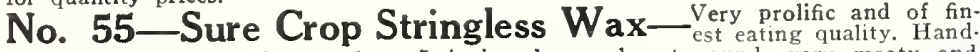
some, rich yellow pods are 6 to 7 inches long, almost round, very meaty and sweet; stringless at all times. Plants very upright in growth, health

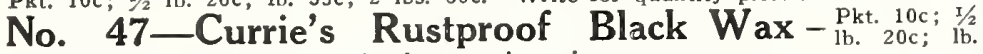
No. 56 - Prolific German Wax, Black-seeded- $1 / 2$ th. 20 . 20 ; 1b. 40c; 2 lbs. $75 \mathrm{c}$, postpaid. Write for quantity prices. Pkt. 10c: $1 / 2$ 1b. 20c; 1b. No. 63-Wardwell's Kidney Wax- Pkt. $10 \mathrm{c} ; \mathrm{T} / \mathrm{lb}$. $20 \mathrm{c}$; $1 \mathrm{~b}$. No. 52-Hodson Wax_- Pkt. 10c; $1 / 2$ lb. 20c; 1 lb. $35 \mathrm{c} ; 2$ lbs. $60 \mathrm{c}$.

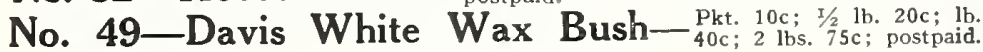
Pole Wax Beans

No. 51-Early Golden Cluster Wax- ${ }_{\text {Bright, }}^{\text {Matures }}$ golden 55 days.

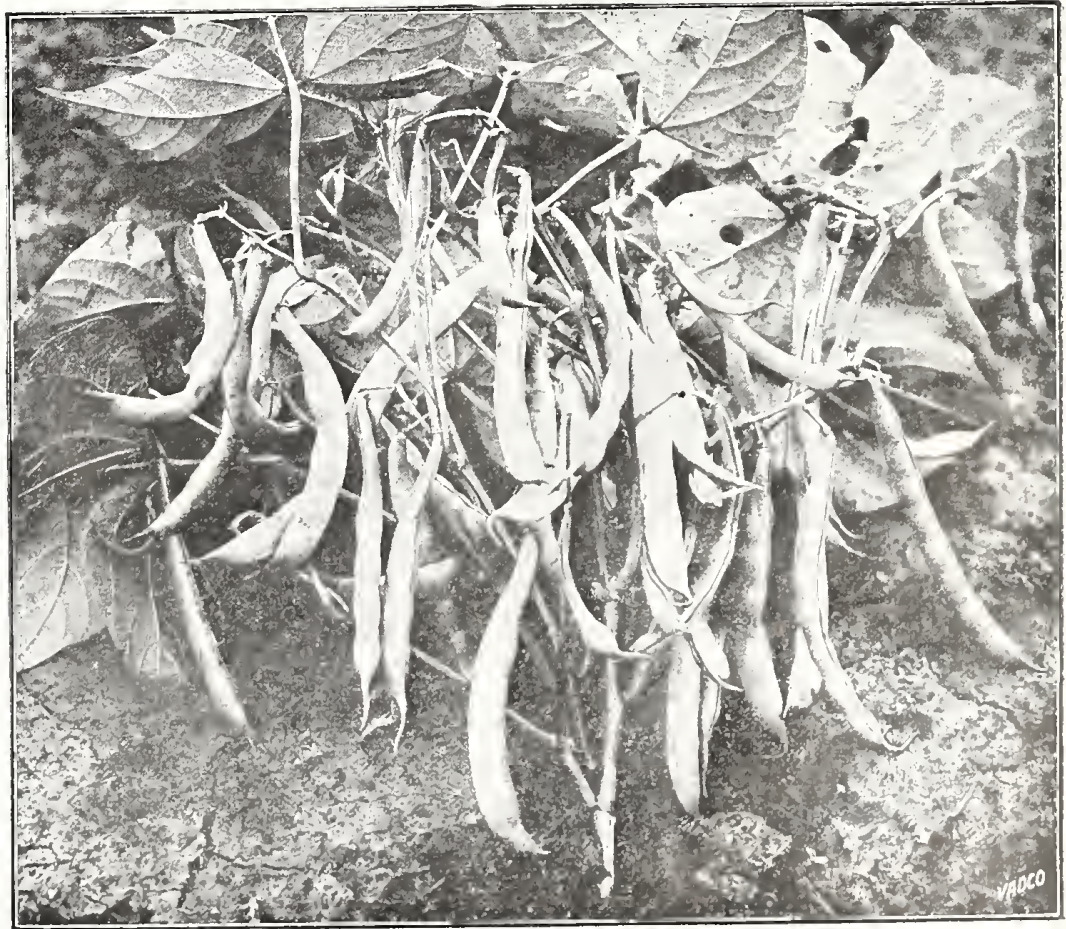
stringless, tender and of most delichis frost. Beans clean, waxy white; an excellent shelled Bean, also. Pkt. 10c; $1 / 2$ lb. $20 \mathrm{c} ; 1 \mathrm{~b} .40 \mathrm{c} ; 2$ lbs. $75 \mathrm{c}$, postpaid.

One plant of Vadco New Green Stringless Beans No. 33 


\section{LIMA OR BUTTER BEANS}

CULTURE-Lima beans are not as hardy as snap beans and should not be planted before the ground is warm and frost is over. Plant bush limas in 3 -foot rows, dropping 3 beans 15 inches apart in the row, eyes downward. For the tall varieties, set 6 to 8-foot poles firmly in the center of the bills 3 feet apart in 4 -foot rows before the seeds are planted. Cover the beans $13 / 2$ inches deep;

Bush Lima or Butter Beans No. 71-Vadco Fordhook Bush Lima- The very best variety. The pods, which are produced in large clusters, are medium
green, about four and three-fourths inches long, each containing three to five large beans of exceptionally fine quality. Don't fail to plant some of $1 \mathrm{lb}, 40 \mathrm{c} ; 2$ lbs. $75 \mathrm{c}$, postpaid. Not prepaid, 15 lbs. (peck) $\$ 4.00 ; 60$ lbs. No. 75-Henderson's Bush- Matter in 50 days. A Dwarf no poles; it grows from 18 to 24 inches high; it is early and productive. Pkt 10c; 1/2 lb. 20c; lb, 35c; 2 lbs. 60c, postpaid. Not prepaid, 15 lbs.

No. 69-Burpee's Bush Lima- A bush form of the Large 20 inches high; the pods and Bears are nearly the same
latter. Pkt. 10c; $1 / 2$ lb. 20c; 1 b. 40 c; 2 lbs. $75 \mathrm{c}$, postpaid.

No. 70-Calico Bush, or Jackson WonderNo. 70 Calico Bush, A perfect bush butter bean growing to 2 feet high. Begins blooming use or as a winter shell bean. Seed of brownish color. Pkt. 10c; $1 / 2 \mathrm{lb}$. $20 \mathrm{c}$; lb. $35 \mathrm{c} ; 2$ lbs. $60 \mathrm{c}$. Not prepaid, 15 lbs. (peck) $\$ 2.50 ; 60$ lbs.

\section{Pole Lima or Butter Beans} No. 101-Vadco Small White Lima, Carolina, or Sieva_Matures in 70 days. Vines vigorous, but sbort, witb many poles; very early and productive, pods short, curved, thin, flat; beans $35 \mathrm{c} ; 2$ lbs, 60c, postpaid. Not prepaid, 15 lbs. (peck) $\$ 2.50 ; 60$ lbs. No. 82-Genuine Willow Leaved Pole LimaIt is early and productive with a leaf that is willow-leaf in sbape. A very Prices: Pkt. 10c; 1/2 lb. 20c; 1b. 35c; 2 lbs. 60c; 5 lbs. $\$ 1.50$, postpaid.

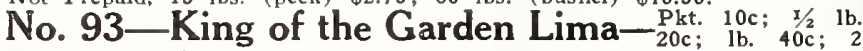
No. 85-Challenger Lima-Matures in 85 days. The vines Pkt. $10 \mathrm{c} ; 1 / 2 \mathrm{lb}, 20 \mathrm{c} ; 1 \mathrm{~b}, 40 \mathrm{c} ;$ No. 97-Large Lima- Pkt. 10c; 13/2 1b. 20c: 1b. 40c; 2 lbs, No. 81-Pole Calico or Florida Butterthe very first bloom that appears on the plants, something that is not true size but are speckled white and brownisb red Pkt 10c: $1 / 21 b .20 \mathrm{c}$; $1 \mathrm{~b} .35 \mathrm{c} ; 2 \mathrm{lbs}$. 60c, postpaid. Not prepaid, $15 \mathrm{lbs}$. (peck) $\$ 2.50$.

\section{LIMA BEAN COLLECTION}

4 Full Packets New Crop Beans

the following Lima Beans: Henderson

Bush Lima, Calico Bush Lima, Burpee's

Order Collection No. 73

The 4 Full-Sized Packets 25c, Postpaid

No. 104 Genuine Cornfield Bean- $\begin{gathered}\text { This is the Genuine Cornfield } \\ \text { Bean for planting in the corn. }\end{gathered}$ Ours is the genuine heavy-bearing stock and can be sown early and late. Price-Pkt. $10 \mathrm{c} ; 1 / 2 \mathrm{lb} .20 \mathrm{c} ; 1 \mathrm{~b} .35 \mathrm{c} ; 2 \mathrm{lbs}$. 60c, postpaid. Not prepaid: $15 \mathrm{lbs}$. (peck) $\$ 3.00 ; 60 \mathrm{lbs}$.

No. 105-White Cornfield Bean- $\begin{gathered}\text { We are glad to offer this white- } \\ \text { seeded variety and can recom }\end{gathered}$ mend it is a good snap bean or as a dry shell bean for winter use. It is a heavy and $10 \mathrm{c} ; 1 / 2 \mathrm{lb}$. 20c; 1b. $35 \mathrm{c} ; 2$ lbs. $60 \mathrm{c}$, postpaid. Not prepaid: $15 \mathrm{lbs}$. (peck) $\$ 2.75 ; 60$ No. 111-Georgian Pole Bean_- A drought and heat resistant pole luxuriant, vigorous grower, very productive. Produces pods 4 inches long, round and prepaid, 15 lbs. (peck) $\$ 2.75 ; 60$ lbs. (bushel) $\$ 10.50$.

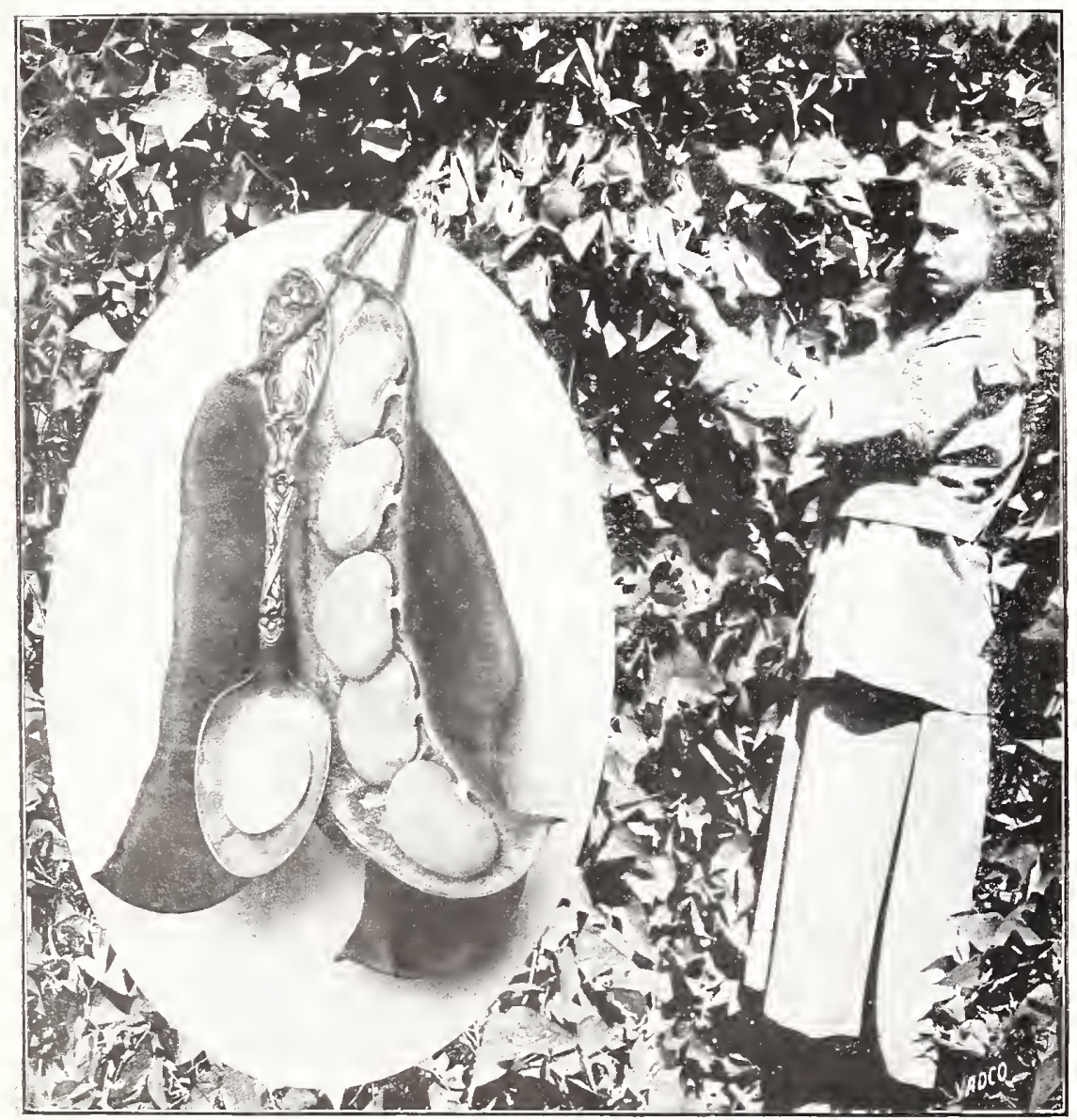

\section{Pole Beans}

LB. TO 100 POLES; 30 LBS. TO ACRE CULTURE-Pole Beans should be planted Set strong poles in the ground from 4 to 6 feet apart, before the seed is planted. It is always best to plant after a rain and with the eye of
the Bean down. The Snap Beans can be planted

No. 112-Vadco Kentucky Wonder, or Old Homestead- Matures in 65 days. A very prolific sort, producing its long pods the market gardener, the pod being very showy and produced in greal $15 \mathrm{lbs}$. (peck) $\$ 2.50 ; 60 \mathrm{lbs}$. (bushel) $\$ 9.00 ; 100 \mathrm{lbs}$. at $14 \mathrm{c}$ per lb.

No. 103-Black Creaseback Pole Bean- This variety was Mobile and is without equal for productive and early qualities. Makes a long. Short crop, no large quantities to offer.

No. 116-McCasland_A white prolific pole bean of the fines Kentucky Wonder. Pods are large. deep green and stringless. Pkt. 10c; $3 / 2$ lb. $20 \mathrm{c} ; 1 \mathrm{~b}$. $35 \mathrm{c} ; 2$ lbs. $60 \mathrm{c}$, postpaid.

No. 109-Lazy Wife-Matures in 55 days. The pods are profrom 6 to 8 inches in length. Broad, thick, very fleshy, entirely stringless and green-podded. Pkt. $10 \mathrm{c} ; \mathrm{x} / 2 \mathrm{lb} .20 \mathrm{c}$; $1 \mathrm{~b} .40 \mathrm{c} ; 2 \mathrm{lbs}$. $75 \mathrm{c}$, postpaid.

No. 117-White Creaseback - Matures in 55 days. Seed crease in the back. A good grower, bears abundantly and if shipped will keep better than most other kinds. Pkt. 10c; $1 / 21 \mathrm{~b} .20 \mathrm{c} ; 1 \mathrm{~b} .35 \mathrm{c} ; 2 \mathrm{lbs} .60 \mathrm{c}$,

No. 118-Striped Creaseback-Prices: Pkt. 10c; $1 / 2,1 \mathrm{~b} .20 \mathrm{c}$ $\$ 1.50$, postpaid. Not prepaid, 15 lbs. (peck) $\$ 2.75 ; 60$ lbs. (bushel) $\$ 10.50$.

No. 113-Scarlet Runner-Matures in 75 days. Fine. Ex. Enghand as a garden Bean. Beautiful flower. Pkt. 10c; $1 / 2$ lb. 25c; lb. 45c. postpaid. 


\section{FINE TABLE BEETS ARE EASILY GROWN}

\begin{abstract}
1 OZ. TO 50 FEET OF DRILL; 6 CULTURE-For earliest use, plant in hotbeds and transplant. For the ground can be worked, in March or early April; successive plantings may be made till the end of July. Beets for winter use should be planted from April till July, soaking the seeds before planting. Beets thrive best in light, loose, fresh, clean,
deeply-worked soil that has been well manured for the previous crop well manured for the previous crop; manure is used. For field culture, plant in drills 2 to $21 / 2$ feet apart, and cover about one inch. Thin out to 4 inches apart. One ounce will sow 50 feet of drill, six to eight pounds, one acre. In the garden from April till July for fall and No. 157-Vadco Mobile Market-Matures in 55 days. A Early Blood Turnip. Has short, up. right top, remarkably uniform roots. Skin and flesh dark red sweet and tender. Very popular with market gardeners. Good for bunching for market and has lasting quality. Pkt. No. 119-Vadco South. ern Market- Matures in 50 been extensively planted by bay gardeners and is preferred by them to any other kind. One of the earliest varieties, regular in shape and of fine Turnip form. Flesh is dark red. Pkt. postpaid.
\end{abstract}

No. 158-Detroit Dark RedThe roots are globular or ovoid. They are smooth and have but little tops. The with a lighte shade. The flesh is tender and the flavor decidedly sweet. A popular favorite for canning because of its extra deep dark red color. Pkt. 10c; 0z. $15 \mathrm{c} ; 1 / 4 \mathrm{lb}$ $35 \mathrm{c} ; 1 \mathrm{~b}$. $\$ 1.00$, postpaid.

No. 121-Crosby's Egyptian- $\underset{p}{\text { An } \text { rove }}$ ment over Egyptian, being equally as early, larger, and less flat, very uniform in size and shape, with $1 / 4$ lb. $25 \mathrm{c}$; $1 \mathrm{~b}, 85 \mathrm{c}$, postpaid.

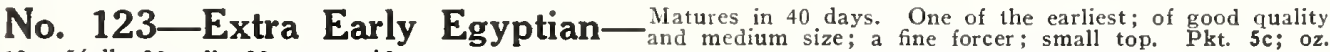
$10 \mathrm{c} ; \mathrm{x} / \mathrm{lb}$ lb 30c; lb. 90c, postpaid.

No. 132-Improved Early Blood-If you are in doubt about what beet to plant, you will The consistent, steady demand shows that it has given unvarying satisfaction. Not as early as the Extra Early The consistent, steady demand shows that it has, given unvarying satisaction. Not as early as the Extra Early
Egyptian, but superior in quality. Of uniform size, with smooth skin free from fibrous roots. Color rich Egyptian, but superior in quality. Of uniform size, with smooth skin free from fibrous roots. Color rich
dark red. Tender, sweet and crisp. Makes an ideal beet for planting in May, June and July to make beets for storing for winter. Pkt. 5c; oz. 10c; $1 / 4 \mathrm{lb}, 25 \mathrm{c} ; 1 \mathrm{~b}$. $75 \mathrm{c}$, postpaid.

No. 129_Lentz's Extra Early Turnip Beet- Matures in 50 days. Very popular with markets. Pkt. 5c; oz. 10c; 1/4 lb. 30c; 1b. 90c, postpaid.

No. 153-Long Blood-Matures in 65 days. Pkt. 10c; 0z. 15c; 1/4 lb. 35c; lb. $\$ 1.00$, postpaid.

No. 163-Swiss Chard, or Silver Beet-The secd should be sown in drills 16 to 20 inches from one to two feet apart in the row. Swiss Chard grows easily in any well-drained, fertile soil. The plants are quite hardy, and will yield throughout the summer and fall until severe frosts touch the foliage. The leaves are usually boiled, similarly to spinach, which they resemble in flavor. The large white ribs are creamed like asparagus. Swiss Chard takes the place of spinach during the hot weat
drill. (See illustration.) Pkt.10c; oz. $15 \mathrm{c} ; 1 / 4 \mathrm{lb} .35 \mathrm{c} ; 1 \mathrm{~b}$. $\$ 1.25$, postpaid.

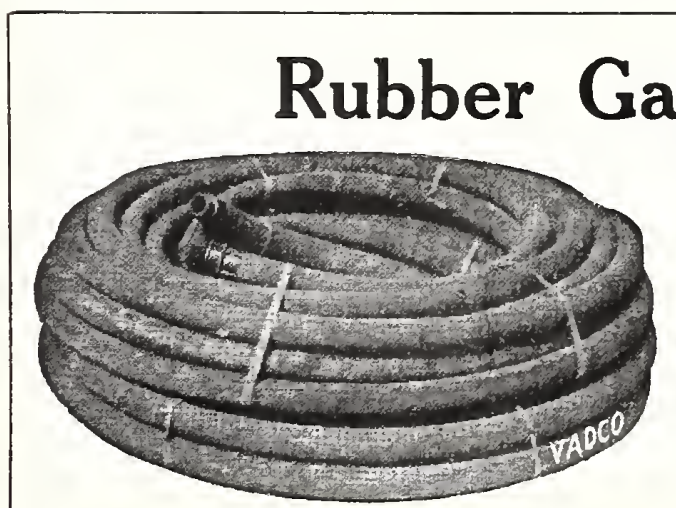

Every garden in the South needs a good rubber Every our Vadco Gusher Brand Hose is the very hosest on the Market. It is made from the best quality non-kinkable rubber and will last for years. Every length is fitted with water-tight couplings free frice: Vadco Gusher Brand Garden Hose, $3 / 4$-inch 25 feet, $\$ 4.00 ; 50$ feet, $\$ 7.50 ; 100$ feet, $\$ 15.00$. Purchaser pays transportation charges. Remember each length is fitted with couplings free of charge.
No. 181_White Cape__ The Cape Broceoli is No. 181 year. The plants are very hardy, vigorous and easily grown. Ple hads are white, compact

\section{Brussels Sprouts}

No. 189-Dwarf Perfection-The most doin every way, growing 18 to 30 inches high and producing compact sprouts" 1 to 2 inches in diameter of grayis lb. $\$ 2.50$, postpaid.

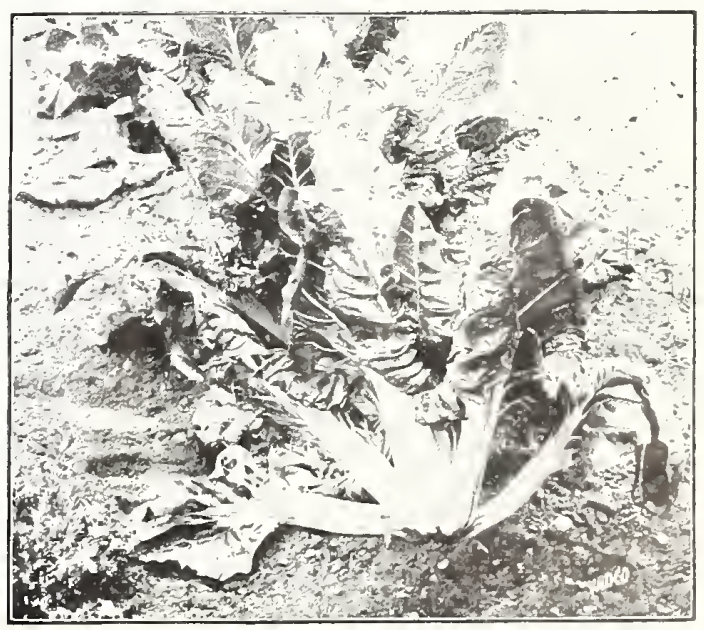

Swiss Chard or Silver Beets No, 163 


\section{ABBAGE}

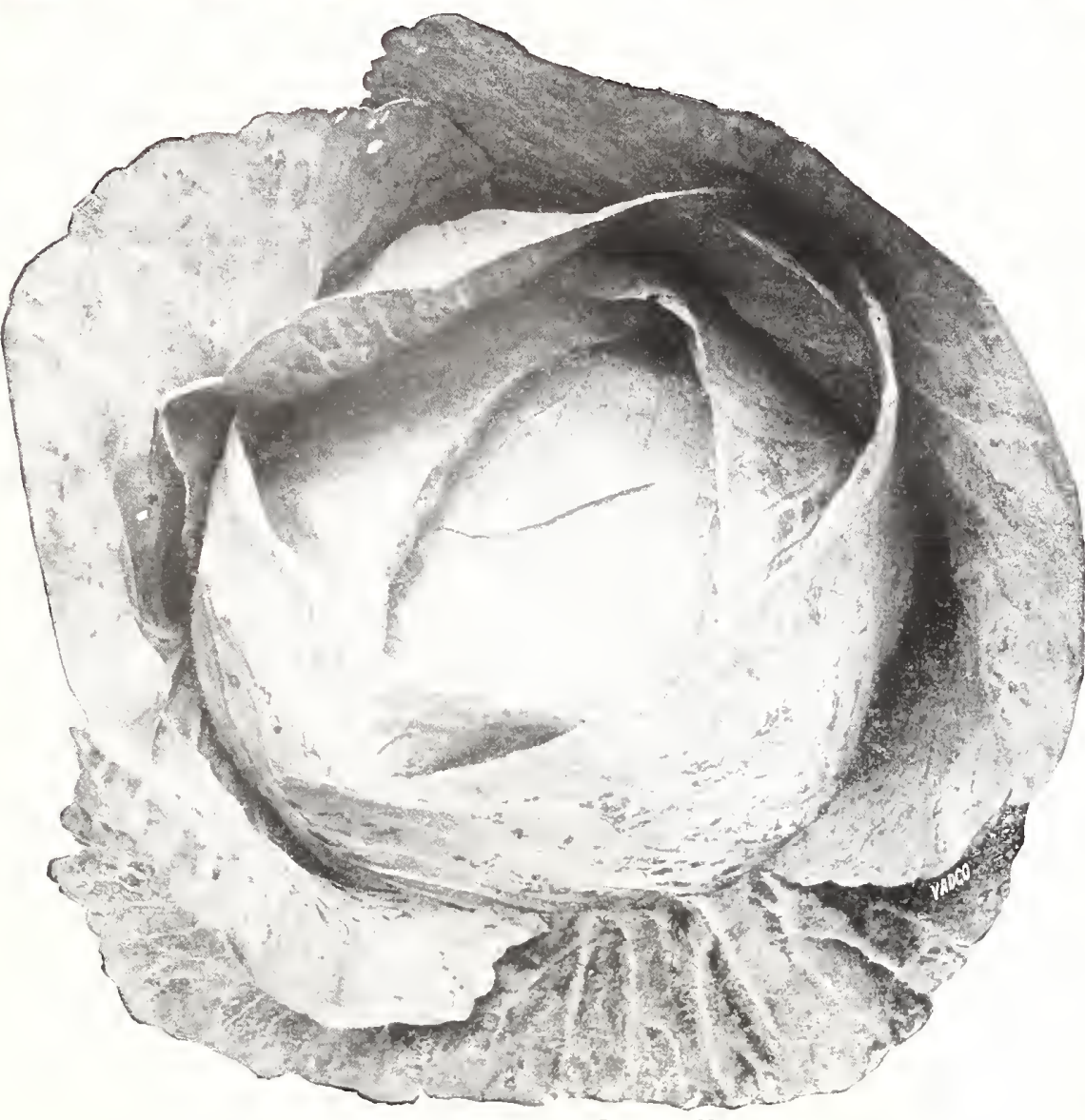

No. 252-Glory of Enkhuizen- Nargely planted in South Texas tor shipping lbs. $\$ 10.00$, postpaid.

No. 243-Drumhead Savoy_ Best late Savoy. Far superior to the ordinar stalk; compact grower; an excellent keeper. $\mathrm{pkt}$. 10c; $02.25 \mathrm{c} ; \mathrm{I} / 4 \mathrm{lb}$. $75 \mathrm{c}$; $1 \mathrm{lb}$. \$2.50, postpaid No. 253-All Head YellowsResistant Cabbage-

bage. A new variety highly resistant to yel
lows. Wisconsin grown seed. Price. $\begin{array}{ll}15 c ; & 1 / 20 z \\ \$ 7.50, & \text { postpaid. }\end{array}$

No. 201-Copenhagen Market

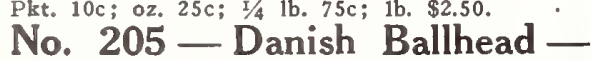
Pkt. $10 \mathrm{c} ;$ oz. $25 \mathrm{c} ; \mathrm{D} / \mathrm{db}$ 1b. $75 \mathrm{c} ; 1 \mathrm{~b}$. $\$ 2.50$. No. 239-Mammoth Rock Red Pkt. 10c; oz. 25c; $2 / 4 \mathrm{lb} .75 \mathrm{c} ; 1 \mathrm{~b}$. $\$ 2.50$, postpaid. No. 247-Chinese Cabbage (Pe Tsai)— Pke. 10c; oz. 30c; $3 / 4 \mathrm{lb} .85 \mathrm{c} ; \mathrm{lb}$. No. 207-Gulf City Drumhead $75 \mathrm{c} ; 1 \mathrm{~b} . \$ 2.50$

\section{COLLARDS}

Cultivated extensively throughout the South food. Can be sown early and late. Grows 2 to
3 foet bint No. 331-Vadco Creole- 70 days. Old standard sort in use in the South for yeats,
A sure cropper, will stand uninjured. Pkt. $10 \mathrm{c}$; No. 329 -Georgia, or Southern Matures in 70 days. A good variety. In many Matures in 70 days, A Aood variety. In many
places where the soil is too poor to grow Cabbage. lb. 30c; lb. 85c; 5 lbs. \$3.00, postpaid.

No. 332-Cabbage- Mays. A variety of Collard, with light, whitish leat.
oz. $20 \mathrm{c} ; \mathrm{s} / \mathrm{lb}$. $40 \mathrm{c} ; \mathrm{lb}$. $\$ 1.25$, postpaid.

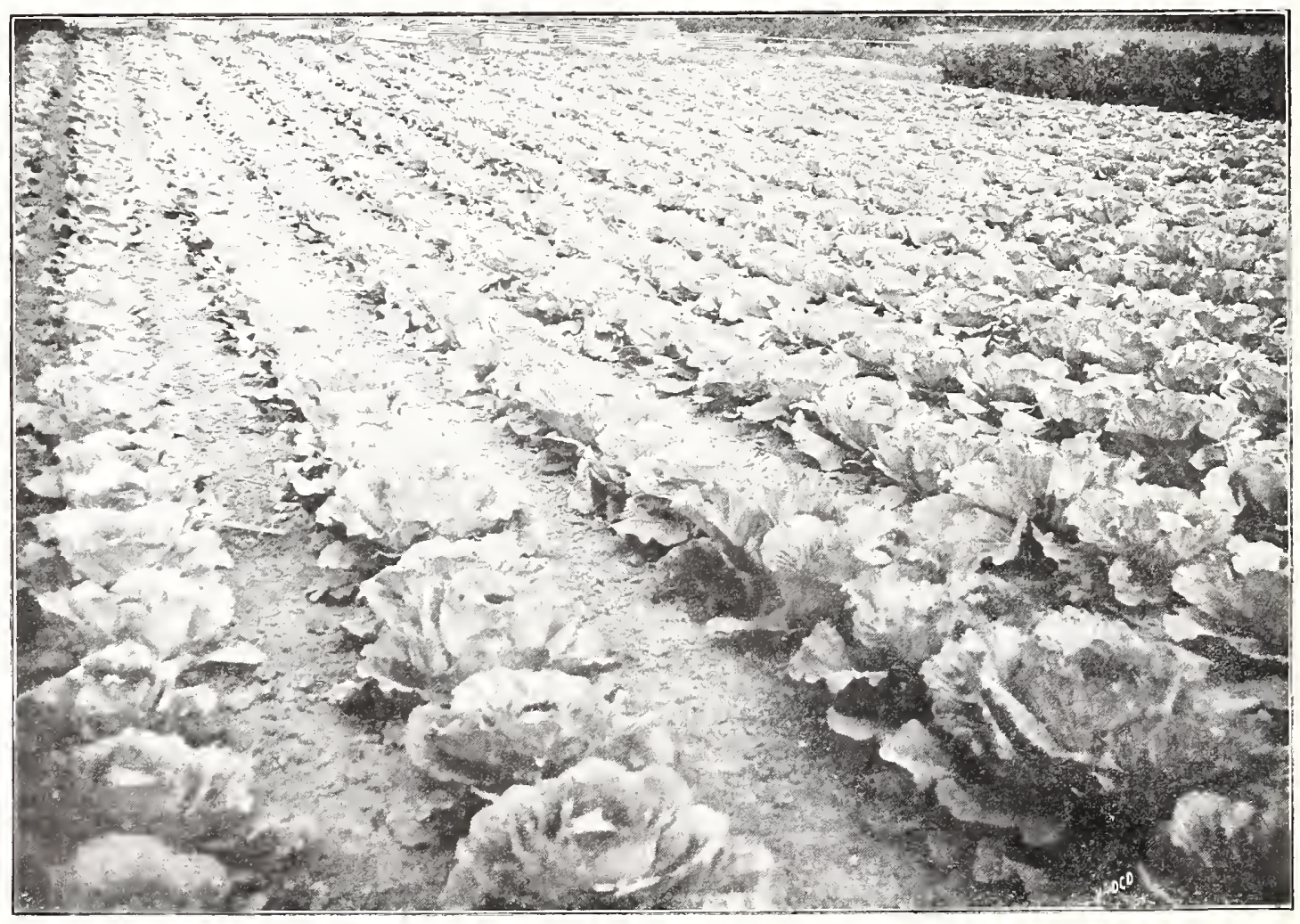

Vadco All Head Early Cabbage No. 215. Note the Uniform Growth.
CULTURE-W When transplanting cabbage plants from the seed bed, set them in good rich soil that has been deeply dug and well manured and should not be richer than the soil where the plants are to grow, otherwise give frequent and deep cultivation, drawing the earth to the plants at each 政 variefies should be set 2 feet apart in 3 foot rows.
One ounce will sow 100 feet of row and produce

No. 215_-Vadco All-Head Early_our strain of special adherence to the type in habit of growth and the shape and quality larger and a little more round than the Early Summer. One of the best Pkt. 10c; oz. 25c; $1 / 4$ 1b. $75 \mathrm{c} ; 1 \mathrm{~b}$. $\$ 2.50 ; 5$ lbs. $\$ 10.00$, postpaid.

No. 248_-Stein's Early Flat Dutch_- The heads are large plant, nearly round and somewhat flattened, close, firm and very solid. If you want the best, early flatheaded cabbage, plant Stein's Early Flat
Dutch. It is a dwarf, compact grower, allowing close planting, a sure coarseness, and of splendid quality. Practically every plant will form a (See illustration.) Pkt. 10c; oz. $25 \mathrm{c}$; $1 / 4 \mathrm{lb} .75 \mathrm{c}$; lb. $\$ 2.50 ; 5 \mathrm{lbs}$. $\$ 10.00$.

No. 212-Improved Early Summer_ Large, round and (he heat admirably. thus qualifying it for a true Summer Cabbage. Should be sown in Novem oz. $25 \mathrm{c} ; 1 / 4 \mathrm{lb} .85 \mathrm{c}$; lb. $\$ 2.50 ; 5$ lbs. $\$ 10.00$, postpaid.

No. 227-All Seasons_ Matures in 110 days. A greatly im. Heads very large, round, solid and of fine quality, keeping as well as for its ability to stand the hot sun and dry weather. Pkt. 10c; oz. 25c

No. 197-Extra Early Jersey Wakefield_T The b e s bage, and the one most extensively grown for home and market. Medium size, pyramidal, pointed, firm and solid, with few outside lea
in shape. Pkt. 10c; oz. $25 \mathrm{c} ; 1 / 4 \mathrm{lb}$. $75 \mathrm{c}$; ib. $\$ 2.50$, postpaid.

No. 199-Vadco Large Charleston WakefieldMatures in about 75 or 80 days. A little iarger and later than the Early Jersey Wakefield, the heads being as solid, but less pointed and
siderably larger. Pkt. 10c; oz. $25 \mathrm{c} ; 1 / 4 \mathrm{~b}$. $75 \mathrm{c} ; 1 \mathrm{~b} . \$ 2.50$, postpaid.

No. 222-Succession- A few days later than Early Summer, Winter variety, as its solid heads make it a good keeper. Pkt. 10c; oz. No. 232_Louisville Large Drumhead-Matures in days. Finest strain of Drumhead in existerce. Bright green foliage. short stem; heads large, round and thick; valuable for Winter; also suit-
able for Fall crop if sown early. Pkt. 10c; oz. 25c; $1 / 4 \mathrm{lb}$. $75 \mathrm{c} ; \mathrm{lb} . \$ 2.25$, postpaid. 


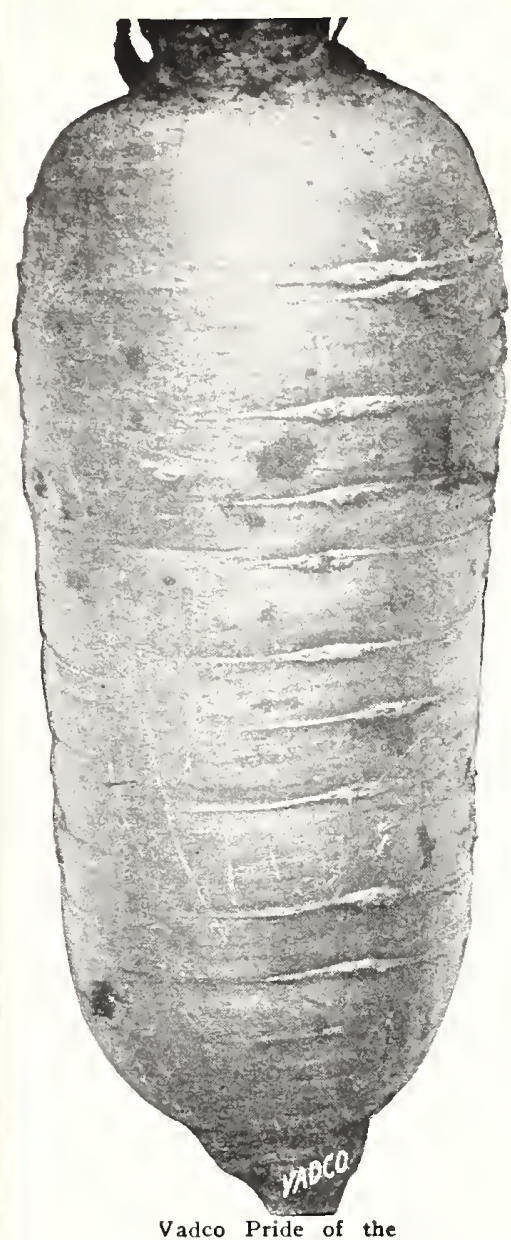

Vadco Pride of the
Market Carrot No. 25

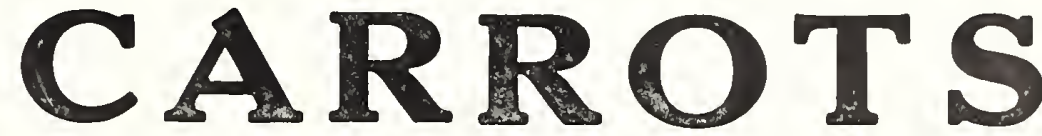

\section{ARE FULL OF NUTRITION \\ Will Grow in Any Garden}

CULTURE-Sow in a ligbt, rich, deeply-worked soil as early as you can work the ground, in drills 12 inches apart and $1 / 2$ inch deep; press the soil firmly after planting and when well up thin out to 3 or 4 inches apart in the row. For field culture, make the drills 18 to 24 inches apart; later sowings should be made in July and August for a late crop to store for winter. In dry weather soak the seeds before sowing.

No. 257-Vadco Pride of the Market_- A half-long sort, unexcelled in deep orange-colored rots ahout 5 inches long and 3 inches in diameter at in growth; deep orange-colored roots about 5 inches long and 3 inches in diameter at top gradually
tapering in a symmetrical manner to the base. (See illustration.) Pkt, 10c; oz. 15c; $1 / 4$ lb. $35 \mathrm{c} ; \mathrm{lb}$. $\$ 1.25 ; 5 \mathrm{lbs}$. $\$ 5.00$, postpaid.

No. 267-Danver's Half Long- The best yariety for general purposes and raising, but for table use as well. Color is a bright orange-scarlet. It is a very beavy cropper. Pkt. $10 \mathrm{c}$; oz. $15 \mathrm{c}$; $1 / 4 \mathrm{lb}$. 30c; 1b. $\$ 1.005 \mathrm{lbs}$. $\$ 4.00$, postpaid,

No. 264-Chantenay- Matures in about 65 days. A stump-rooted variety, $35 \mathrm{c}$; $1 \mathrm{~b}$. $\$ 1.00 ; 5$ lbs. $\$ 4.00$, postpaid.

No. 259-Half-Long Scarlet French_- Matures in about 55 days. Ex. well as \{amily use. Pkt. $5 \mathrm{c}$; 0z. $15 \mathrm{c} ; 1 / 4 \mathrm{lb}$. $25 \mathrm{c}$; lb. $85 \mathrm{c}$, postpaid.

No. 255-Oxheart—Matures in about 60 days. Can be easily pulled; especially No. 255-Oxheart- adapted to shallow soils. (See illustration.) Pkt. 5c; oz.

No. 269-Improved Long Orange- Especially fine on light soils, making deep orange color, free from side roots and superior in every respect. A fine winter sort for table, market and stock. Pkt. $5 \mathrm{c}$; oz. $10 \mathrm{c} ; \mathrm{r} / 4 \mathrm{lb}$. 25c; $1 \mathrm{~b}$. $75 \mathrm{c}$, postpaid.

\section{Carrots for Feeding Cattle}

No. 273-Large White Belgium- Makes a long white root, about oncis easily pulled. A good keeper for late feeding. Pkt. $5 \mathrm{c} ; 0 z .10 \mathrm{c} ; 1 / 4 \mathrm{lb} .20 \mathrm{c} ; 1 \mathrm{~b} .75 \mathrm{c}$, postpaid.

\section{CAULIFLOWER}

CULTURE-When grown to perfection, Cauliflower is a most delicious vegetable and it well repays generous treatment in cultivation. With a deep, rich soll and abundance of moisture, which in dry seasons must be applied artificially, Cauliflower can be grown well. Frequent and vigorous hoeing and a liberal supply of ricb, liquid manure, to keep up a continuous and rapid growth, will produce
oplendid heads of the most delicate flavor.

No. 275-V a d c o N e w Early Snowflake_- ${ }_{\mathrm{qu}}^{\mathrm{By}}$ iar the $\mathrm{\text {tat }}$ cauliflower grown. Ten to fifteen days earlier than any other variety of cauli. that are solid and very compact. Every plant will make a head where other varie. ties fail to succeed. Gardeners should give this variety a trial as we feel conin doubt as to its merits. Good cauliflower has always a ready market. (See

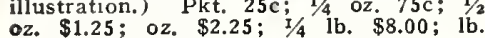
oz. $\$ 1.25$; oz.
30.00, postpaid.

No. 277-Early Snowball Matures in 90 to 95 days. Exceedingly early and hardy and is one of the surest to make a solid, compact head. $15 \mathrm{c} ; 1 / 4$ oz. $65 \mathrm{c}$; $1 / 4 \mathrm{lb}$. $\$ 7.50$; lb. $\$ 28.00$, postpaid.

No. $279-E$ a r 1 y Dwarf Erfurt-Matures in 90 to 95 days.

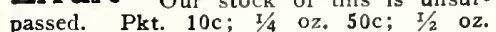

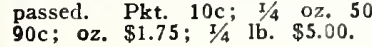

No. 285-Large AlgiersMatures in 110 days. A valuable late cort, sure to head, of the best quality and very popular with market gardeners. Plt. 10 ; ; 1b. $\$ 5.00$; lb. $\$ 18.50$.

\section{PREMIUMS}

A number of both valuable and useful premiums are illustrated on page 7 . Be sure to look them over.

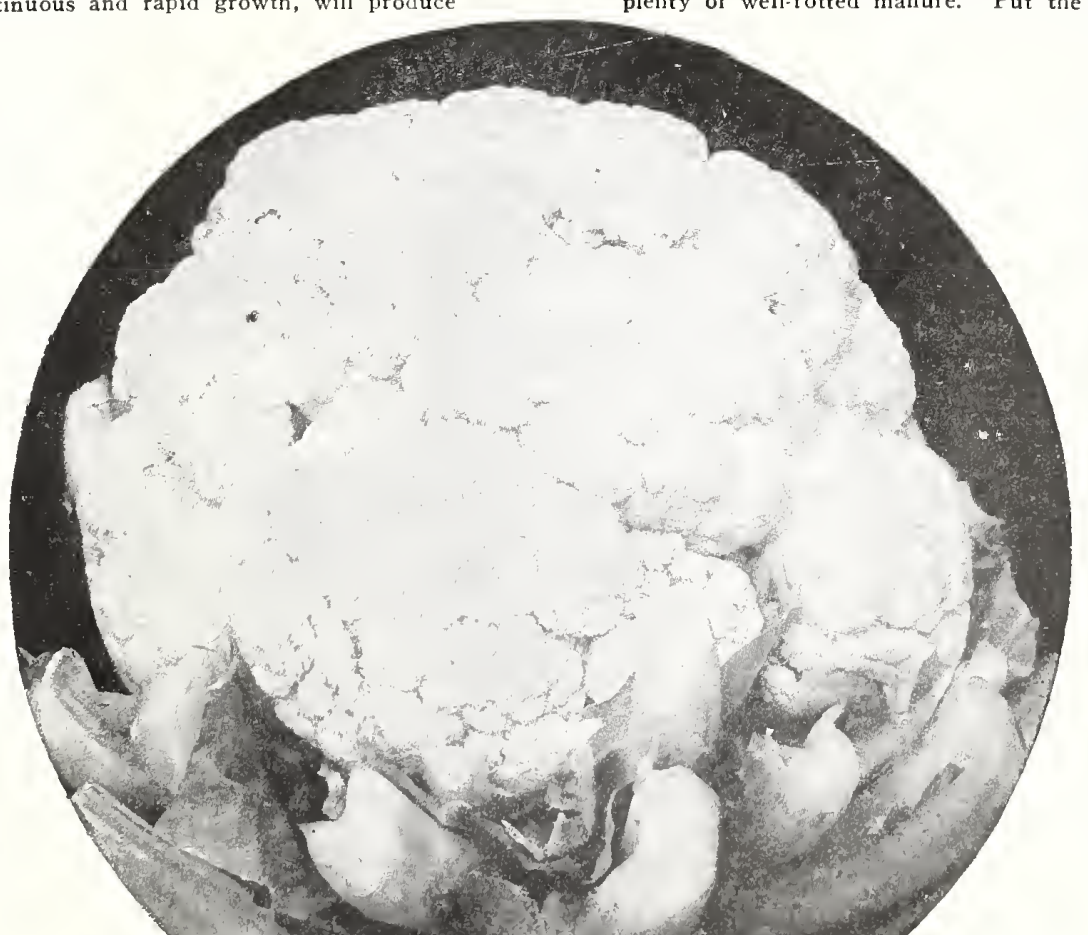

One ounce will sow 100 feet of row. Produce 5,000 plants.

CULTURE-Sow in a well-prepared bed; shade by means of a cotton tent buil over the seed-bed and keep moist; when 5 or 6 inches high transplant. A ditcb (a) shade them during the first few dayo and water them frequently; liquid manure grow, draw the soil around them and stems for use up so as to blanch the No. 298-Golden Plume or Wonderful-a new type Blanching with wider leaves and thicker stems. It matures fully as early as tbat variety and in many localities has been found to be more resistant to attacks o blight and rust. The plants are semidwarf, stocky and vigorous. Prices: Pkt. $15 \mathrm{c} ; 1 / 20 \mathrm{Oz}, 70 \mathrm{c} ;$ oz. $\$ 1.25 ; 1 / 4 \mathrm{lb} . \$ 4.00$;
lb. $\$ 15.00$, postpaid. Vadco Golden Self-Blanch. ing-Matures in 110 days. One o and soil and is our princour climate variety. Heart is solid, very tender, beautiful, golden yellow color; the rib blancittle and of a delica No, 297 - French-Crown

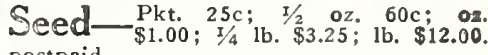
postpaid.

No. 295-White PlumeMatures in 100 days. Unlike most varie earthed up, but if only loosely tied. Pkt. 10c; oz. $25 \mathrm{c}$; $1 / 4 \mathrm{lb} .75 \mathrm{c}$; lb. $\$ 2.50$ No. 307-Giant PascalPkt. 10c; oz. $30 \mathrm{c}$; $1 / 4 \mathrm{lb} .85 \mathrm{c}$; lb. $\$ 3.00$. No. 311-Turnip-R o o t e d, or German Celery - Grown exclusively for turnip-shaped, very smooth, tender and narrow.
like. The roots are cooked and sliced, or ugec with vinegar, they make an excellcint salad. Plre with vinegar, they make an excellcist salad. 
CULTURE-The ground for Corn should be deeply lowed or spaded, then laid off in hills 3 or 4 feet apar or four plants in hill, of the early sorts, while two plants in hill, 5 or 6 feet apart, is' close enough for the large field Corn. Rich, deep loam affords the plants plenty of moisture and nourishment, which the Corn likes. If the ground is not rich, put about a shovelulul of decture.
0 the hill. Sow from February until end of June. In favorable seasons Corn may be planted as late as July and August. Plant four or five kernels to the hil and cover 2 inches deep; when they are up, thrn out ac-
cording to variety. Hoe deep and often while young, draw(a)

No. 383-Vadco Stowell's EvergreenA late Corn. Matures in about 80 days from germination. large, with deep, tender, sugary grains and remains fi Sweet Corn. A very productive and hardy variety. Adapt able either as early or late sort; fine for private gardens,

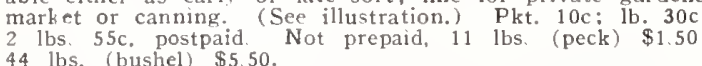

No. 391-Vadco Country GentlemanMatures in about 70 days from germination. Ears of good size, fine flavor and produce in great abundance, many

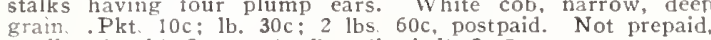
11 lbs. (peck) $\$ 1.50 ; 44$ lbs. (bushel) $\$ 5.75$.

No. 351_Golden Bantam- Ma a t u r e s in An early Sweet Corn with golden-yeliow grain of tender and excellent quality; flavor rich and delicious. Is very Height about 4 feet. Pkt. 10c: lb. 30c: 2 lbs. $60 c$

No. 355-Extra Early MinnesotaMatures in about 60 days from germination. Stalks grow Not prepaid, 11 lbs. (peck) $\$ 1.50 ; 44$ lbs. (bushel) $\$ 5.75$.

No. 367-Black Mexican- Matures in abou from germination. Late sort; dark purple grains-a nov elty in Corn. Of the finest quality
$10 \mathrm{c}: \mathrm{lb}, 30 \mathrm{c}: 2$ lbs. 60c, postpaid.

FREE. 4 Packets Beautiful Flower Seeds with every $50 \mathrm{c}$ order. See inside front cover.
No. 375_Golden Giant_- ${ }_{\text {Golden }}^{\text {cross between }}$ and Howling Mob. It matures about a week after Gelden lantam A strong grower and very productive. Of excel lent quality. Pkt. $10 \mathrm{c} ; 1 \mathrm{~b}$. 30c; 2 lbs. 60c, postpaid,

No. 361 - Evergreen Golden BantamThe new variety is cross between Stowells Evergreen and Golden Bantam. Lighter in color than Golden Ban. tam but holds its most delicious flavor and adds the lb. 30c; 2 lbs. 55c, postpaid. Not prepaid, 11 lbs. (peck)

\section{Early Garden or Roasting Ear Corn}

No. 395 - Vadco Large Adam's Ready for table about 68 days after germination. A popular table Corn, and much planted for first crop. Ears' of good size, larger than those of the Extra Early Adams, very Pkt 10c. 1b 30c: 2 lbs, 50c, postpaid. Not prepaid, 14 lbs. (peck) $\$ 1.25 ; 56$ lbs. (bushel) $\$ 4.25$.

No. 398_Vadco Trucker's FavoriteTruckers Favorite is an early corn, in fact, earlier than White Dent. It's a beautiful white deep grain corn and pro-
duces 2 or more ears to the stalk. It is a splendid roasting ear variety, tender and sweet. See illustration. Pkt. 30c:
lb. 30c: 2 lbs. 50c, postpaid. Not prepaid. 14 lbs. (peck)
$\$ 1.25: 56$ lbs. (bushel) \$4.25.

\section{Seed Pop Corn}

No. 399-White Rice_- The most popular vashort: kernels long, pointed and resemble rice; hence its 2 lbs. $50 \mathrm{c}$, postpaid.

No. 402_Queen's Golden- A $\begin{gathered}\text { A large - eared } \\ \text { handsome }\end{gathered}$ yellow pop corn: grams large, pop perfectly white and are year two-year-old Rice Pop-Corn, especially for parching. year, two-year-old Rice Pop-Corn, especially for parch
Pops large and white. Lb. 20c; 2 lbs. 35c, postpaid.

\section{BIG CORN COLLECTION No. 8 FOR 25c}

1 Packet Stowells Evergreen

1 Packet Country Gentleman
1 Packet Golden Bantam

1 Packet Trucker's Favorite

These 4 full size packets all for 25 c, postpaid Order Collection No. 8

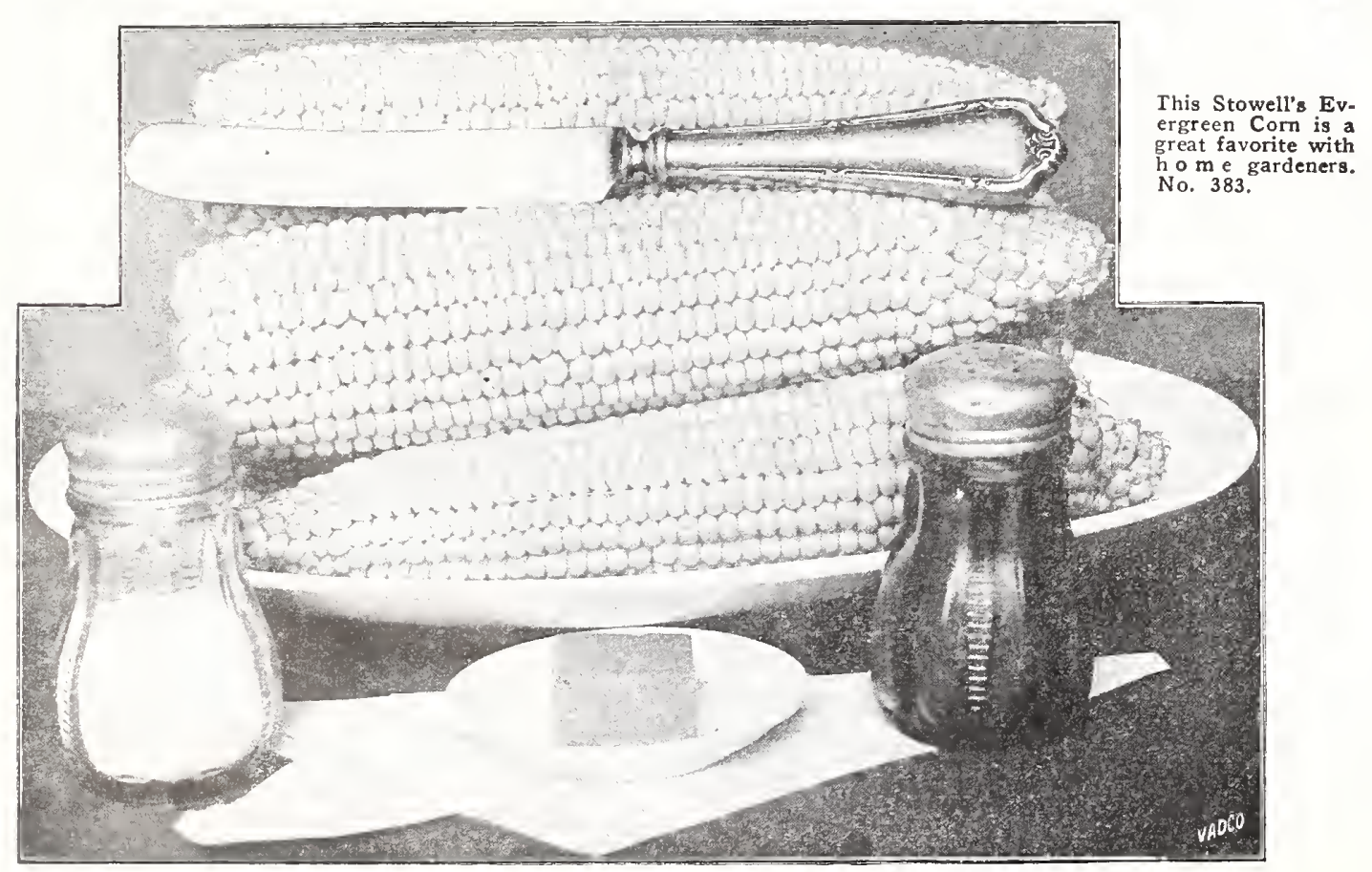

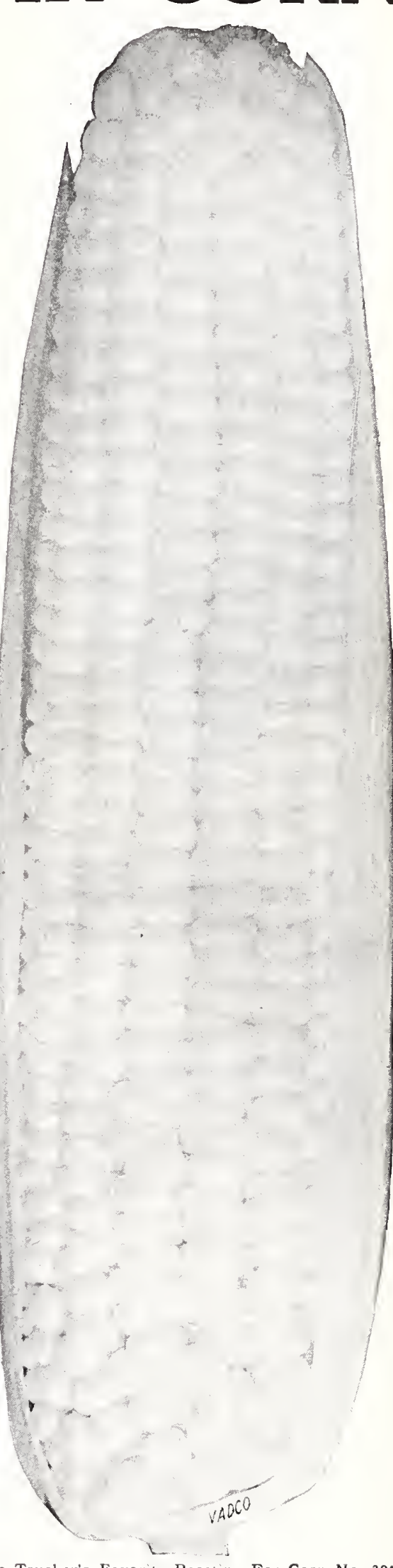

Vadco Trucker's Favorite Roasting Ear Corn No. 398

\section{PREMIUMS}

Articles needed by every family. See Page 7. Look it over NOW. 


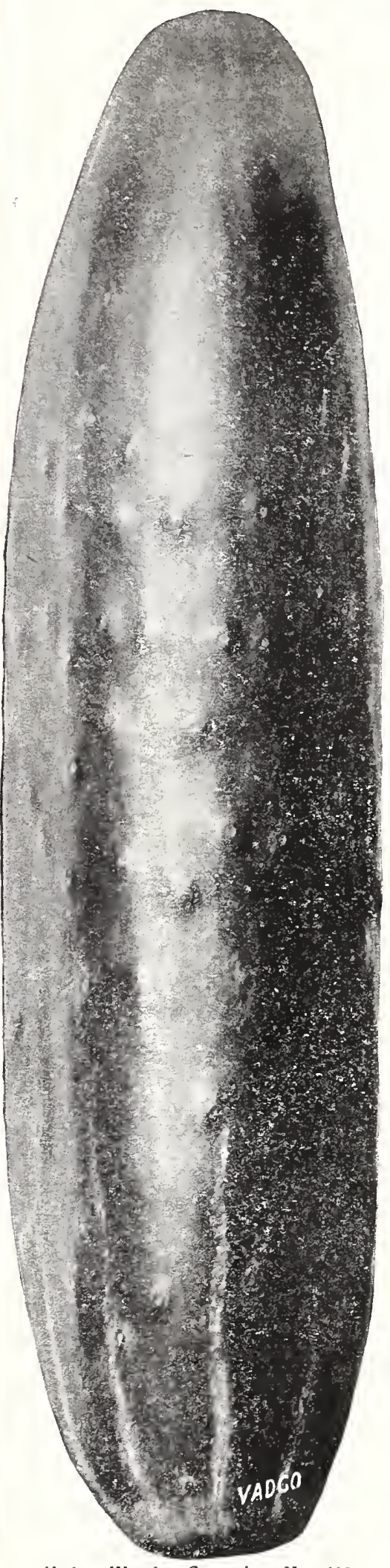

CUCUMBERS Ideal Home Garden
and Market Sorts

CULTURE-Cucumbers may be planted here as early as March, or as soon as it can be done with safety, as the plant is very tender and will not bear the least frost. If the ground is deeply trenched, the plant is much less susceptible to drought. Plant in hills 3 to 4 feet apart. The ground should be rich. A little guano or fow manure, or well-decomposed stable mantre will be very beneficial. Do not use fresh manure or the vines stop and they will fruit the sooner. Cucumbers are subject, in cool, dry seasons, to the attacks of insects, especially the bug and cucumber fly. Dry wood-ashes, or air-slacked will genoroughly dust

No. 447-Money-Maker- ${ }_{\text {Cucumber. Illustrated }}^{A}$ wonder and described on page 11. Pkt. 10c; oz. $15 \mathrm{c} ; 1 / 4 \mathrm{lb} .45 \mathrm{c} ; 1 \mathrm{~b}$ No. 413-Vadco Wonder- Our Vadco Wonder variety for market or home gardens. The fruits measure about 10 inches long and the avcrage weight 2 lbs. The color is rich deep green and the fruits are uniform in shape and size. Every fruit is shapely and holds its fine cylindrical shape clear
to the stem end. The Vadco Wonder is about the same size the Dayis Perfect

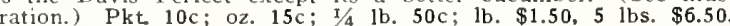

No. 446-The Kirby Cucumber- It $S$ t a : Originator's Stock. Earliest of the White Spine type; fruit or 8 inches long, cylindrical in shape. Color a beautiful dark any variety we know of. Vigorous grower, enormous yielder hipping quality unexcelled, and always commands the highes No. 439 Klondlse Hays - Klondyke- Matures in about germination. Medium early, white spine; variety of handsome, very dark green and productive. Fruit is of uniform size and shape and i about 8 inches long. Pkt. $10 \mathrm{c} ; 0 \mathrm{z} .15 \mathrm{c} ; \mathrm{x} / 4 \mathrm{lb}$. $40 \mathrm{c}$; lb. $\$ 1.25$;

No. 433-Early White Spine- It is and extra crisp and tender, holding its fresh, dark green appearance long 5 lbs. $\$ 5.00$, postpaid.

No. 419-Long Green Improved-Matures in long variety, 15 to 18 inches long when well grown. Very
fine and productive. Pkt. $10 \mathrm{c} ; 0 \mathrm{z} .15 \mathrm{c} ; \mathrm{I} / \mathrm{lb}$. 50c; $1 \mathrm{~b}$. $\$ 1.50$, No. 429-Early Fortune- This variety is used sections. Pkt. 10c; oz. $15 \mathrm{c}$; $1 / 4 \mathrm{lb} .40 \mathrm{c}$; $1 \mathrm{~b} . \$ 1.25$, postpaid. No. 427-Vadco Davis Perfect_-_Extra early metrical fruits of an intense, deep green color. Has few seeds which, when the cucumbers are at their best, are so small and tender as to he atonnst unnoticeable. Pkt. 10c; oz. $15 \mathrm{c}$ INo. 445-Gherkin, or Burr- (West In d i a n sively grown for pickling; the smallest of all; should be picked $\$ 1.50$, postpaid.

No. 421 - Picklers Special Cucumber (Heinz) _ A recent introduction and by far the best pickensively by the Heinz company Prices: Pkt 10c; 0z. 15c

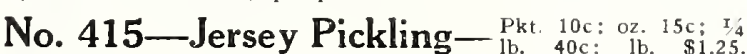

No. 442 -Japanese Climber- Matures in 60 small gardens, as they can be trained on trellises or othe upport, thereby taking up very little space. Pkt. 10c: oz.

\section{(1)}

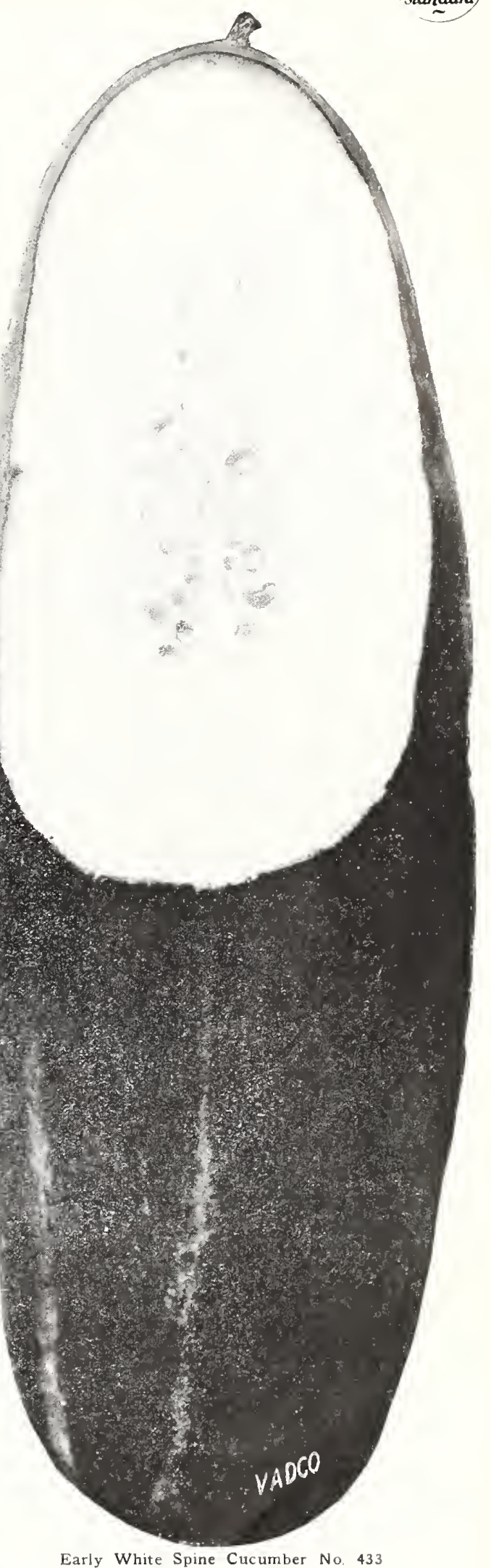

Early White Spine Cucumber No. 433

\section{Cucumber Collection No. 7}

This collection contains 1 packet each Vadco Wonder, Early White Spine, Davis Perfect and Jersey Pickling Cucumbers.

The 4 full size packets mailed postpaid for $25 \mathrm{c}$ Order Collection No. 7

\section{Herbs for Your Garden}

Aromatic Herbs are those which possess medicinal as well as culinary properties, and should be found herbs for use, cut them on a sunny day, and spread thinly in the shade to dry.
her the

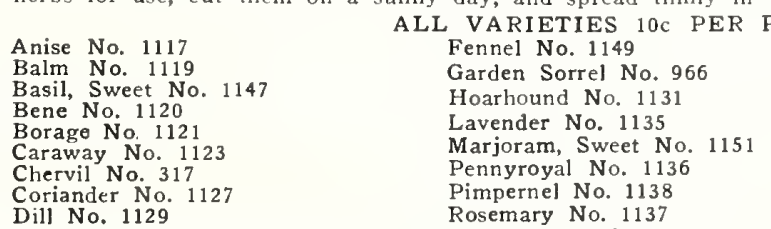

Price. Your choice any of the above Herbs for $10 \mathrm{c}$ packet, 3 packets $25 \mathrm{c}$. 6 for $50 \mathrm{c}$. 
BE SURE TO READ THIS PAGE OVER, YOU WILL FIND MANY CHOICE VEGETABLES

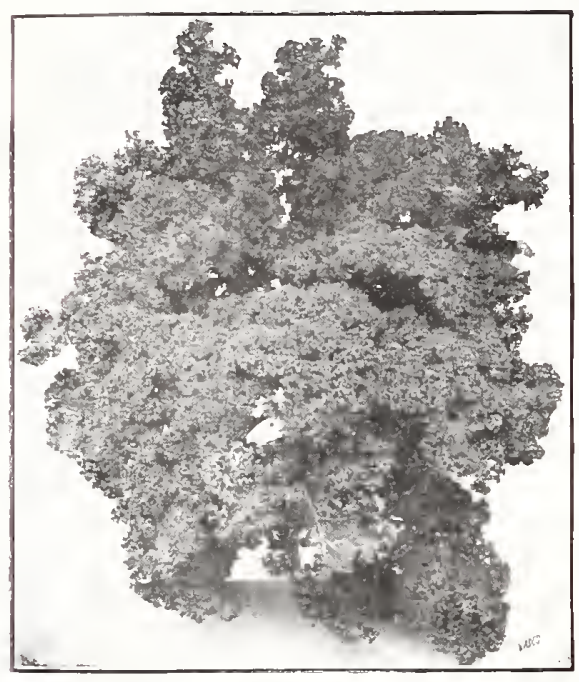

Vadco Extra Dwarf Curled Scotch Kale No. 612

\section{Kale or Borecole}

Scotch Kale should be sown from the latter part of March to last of August; Siberian Kale from middle of August to last of September. Sow in rows from 2 to 3 feet apart, thinning later to 6 to 8 inches in the can be sown either in fall or spring.

No. 612-Vadco Extra Dwarf Curled Scotch - Largely grown for supplying "greens" dur. are bardy above zero; frost improves the quality. The leaves are very large, deeply curled and fringed, and of Plet. $10 \mathrm{c}$; oz. $15 \mathrm{c} ; \mathrm{t} / 4 \mathrm{Ib}, 35 \mathrm{c}$; lb. $\$ 1.25$, postpaid.

No. 615 - Tall Curled Scotch Matures in 60 days. Very hardy; will stand our win ters very well, 2 to 3 feet talf; dark, green leaves, densely oz. $10 \mathrm{c} ; 1 / 4$ lb. $25 \mathrm{c}$; lb. $75 \mathrm{c}$, postpaid.

No. 617 - Siberian or German A very hardy variety. Popular with the market garlb. $75 \mathrm{c}$, postpaid.

No. 618-Spring, or Smooth KaleSprowing smooth-leaved variety. Pkt

\section{Endive}

CULTURE-A salad plant that is very popular and much cultivated for the market principally for summer ase. Sow in drills a foot apart; or it can be sown for the leaves are about 8 inches long, tie them up No. 603-Vadco Green CurledMost popular variety among the market gardeners. Beautifully curled leaves, blanching very easily; very
crisp and tender. Pkt. 10c; oz. $15 \mathrm{c} ; \mathrm{I} / 4 \mathrm{lb}$. 50c; lb. crisp and tender.

No. 605-Broad-Leaved Escarolleof the same good qualities as the foregoing. Leaves broader and less curled. It does not stand the heat so and winter. Pkt, 10c; oz. 15c; $1 / 4 \mathrm{lb}, 40 \mathrm{c}$; lb. $\$ 1.25$, postpaid.

\section{Parsley}

One ounce for 150 feet of drill

CULTURE-Can be sown during the fall from August to October, and during spring from the end of January Soak the seed for twenty-four hours and mix with sand; it is very slow to germinate, and sometimes remains its appearance.

No. 797 - Vadco Double-Curled Plants of dwarf compact growth, and the young leaves bave the edges heavily crimped, giving a general appear$10 \mathrm{c} ; 0 z .15 \mathrm{c}$; $1 / 4 \mathrm{lb}$. $35 \mathrm{c}$; lb. $\$ 1.00$, postpaid.

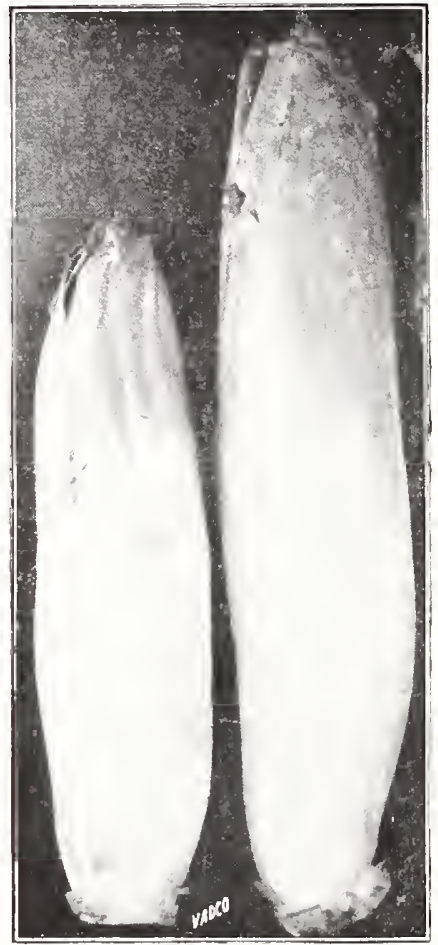

Witloof Chicory No. 322

No. 801-Champion Moss CurledSixty-five days to cutting. Especially recommended for market gardeners, as it stands the winter well; is of $1 / 4$ lb. $30 \mathrm{c}$; $1 \mathrm{~b} .85 \mathrm{c}$, postpaid.

No. 795-Plain, or Single Parsleyvery dark green, with plain leaves. Pkt. 5c; oz. 15c;
$1 / 4$ Ib. 25c; 1b. 75c, postpaid.

\section{Mustard}

This is grown to quite an extent in the Southern States and is sown broadcast during fall, winter and with meat as Greens.

No. 755 - Vadco Fancy Curled Matures in 39 days. The most beautiful of all curled Mustard. Leaves curved outward like a fine ostrich growth; to grow to perfection you will have to thin $\$ 2.00$, postpaid.

No. 765-Broad-Leaved-Matures in 30 early variety. Pkt. 5c; oz, 10c; I/4 Ib. 20c; 1b. 50c; 5 lbs. $\$ 2.00$, postpaid.

No. 763_White_Matures in 35 days This tard. Pkt. 5c; oz. 10c; 1/4 lb. 25c; lb. 75c, postpaid.

No. 761 -Chinese_Large, succulent leaves. $5 \mathrm{c}$; $0 z .10 \mathrm{c}$; $1 / 4 \mathrm{lb} .25 \mathrm{c}$; lb. $75 \mathrm{c}$, postpaid.

\section{Kohl-Rabi}

CULTURE-Sow either broadcast or in drills, afterward thin out to 1 foot apart, or transplant to the
same distance. Sow in August and September and again from January till April.

No. 619-Early White ViennaThe only variety planted in the South. Excellent for the table. Large, light green head and short leaves.
See illustration. Pkt. $10 \mathrm{c} ;$ oz. $25 \mathrm{c} ; \mathrm{I} / 4$ lb. $75 \mathrm{c}$; lb See illustration.
$\$ 2.50$, postpaid.

No. 620 - Early Purple ViennaVery early, with small top, the leaf stems being tinged with purple. Bulbs of medium size, purple; flesh white. $10 \mathrm{c} ; 0 z, 25 \mathrm{c} ; 1 / 4 \mathrm{lb} .75 \mathrm{c}$; lb. $\$ 2.50$, postpaid.

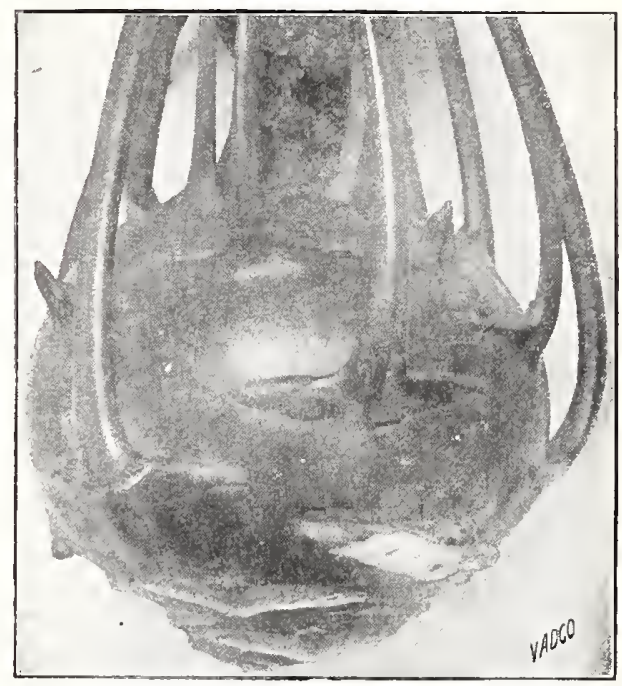

Early White Vienna Kohl-Rabi No. 619

\section{Leek}

CULTURE-The Leek succeeds best in light, well enriched soit 6 inches apart. Put the plants 4 inches in the ground, to make them white and tender.

No. 623 - Large Carenten LeekGrows to large size, the stems being proportionately large and thick. in diameter. Pkt. $10 \mathrm{c}$; oz. $25 \mathrm{c} ; \mathrm{1} / 4 \mathrm{lb}, 75 \mathrm{c}$, postpaid.

No. 321 - Chicory, Large, Largerooted, or Coffee- The roots are cut in thin coffee, for a beverage. The leaves make a good salad. Pkt. 10c; oz. 25c; $1 / 4$ lb. $75 \mathrm{c}$, postpaid.

No. 322-Chicory Witloof- See illustra. $10 \mathrm{c}$; $0 z .25 \mathrm{c} ; \mathrm{3} / \mathrm{l} \mathrm{lb}$. 75c, postpaid.

No. 325-Chives or Cives-A hardy nial plant of the Onion tribe, growing in nests. The bunches are made up of a mass of little bulbs. Pkt. $10 \mathrm{c} ; 1 / 2 \mathrm{2}$ 0z. 35c; oz. $65 \mathrm{c}$, postpaid.

No. 335-Corn Salad-sow n broadcas February and used as a salad. Very often when heavy postpaid.

Cress-Sow broadcast from early fall until February Cress - and March. Much used for salad.

No. 344-Upland-The only one planted for oz. $25 \mathrm{c}$; $1 / 4 \mathrm{lb}$ l. $75 \mathrm{c}$, postpaid.

No 342-Water - Can be sown only by the near springs. Pkt. 10c; oz. $40 c$; $1 / 4 \mathrm{lb}$. $\$ 1.25$, postpaid No. 291-Cardoon Large SpanishLarge, fleshy leaved. The stalks, rendered white and tender by blanching, are used in stews, soups and No. 317-Chervil-A small plant resembling oyster soup. Pkt. 10c; oz. $25 \mathrm{c} ; \mathrm{s} / 4 \mathrm{lb}$. $\$ 1.25$, postpaid. No. 449-Dandelion, Thick LeafA very early and healthful salad. Sow early in drills, 18 inches apart. Pkt. 10c; 0z. $15 \mathrm{c}$; 1/4 lb. \$2.50, post Salsify, or Oyster Plant

CULTURE-A vegetable which ought to be more cultivated than it is. It should be sown in the fall of the year, not later than November. The ground ought to be manured the spring previous, deeply spaded, and well pulverized. Sow in drills about 10 inches

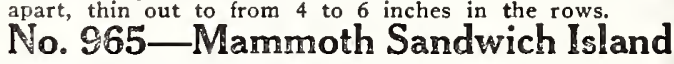
A great improvement over the old sort, growing double in size . Pkt. 10c; $1 / 2$ oz. 20c; 0z. 30c; $1 / 4$ lb. 85c; No. 966-Sorrel_ Planted in drills a foot The apart during the fall of the year and thined also in soup and salad. Cooked like spinach. Pkt. 10c; oz. $25 \mathrm{c}$; $1 / 4$ lb. $75 \mathrm{c}$, postpaid. 


\section{VAN ANTWERP'S LETTUCE SEED FOR SOUTHERN}

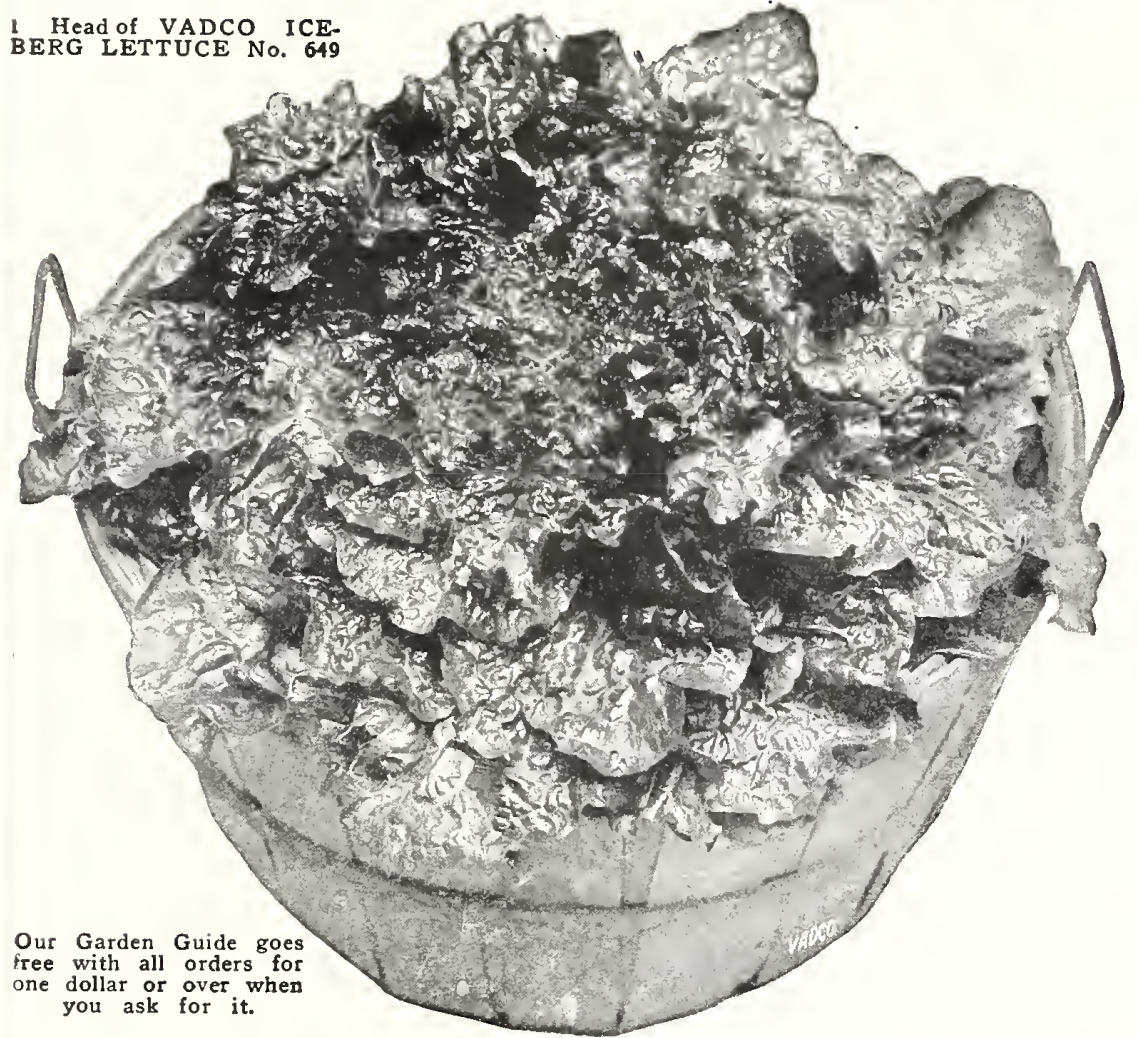

One ounce will produce 3,000 plants. Three pounds to acre. Forty to fifty days from seeding to maturity

CULTURE-Lettuce is sown here during the whole year by the market gardeners. Of course, it takes a great deal of labor to produce this vege.
table during our hot summer months. The richer and better the ground. the larger the head will be. No finer Lettuce is grown anywhere than in Mobile during the fall and spring. The seed should be sown broad inches apart in the row.

No. 639-Vadco Selected Big Boskon- A so 1 id head Has very few wasted leaves; indeed, the plant is nearly all heart, exceedingly
crisp and sweet. Well adapted for spring and fall culture and for forcing thousands of acres of it are grown during the winter Florida and Southern States for shipping to Northern markets. Withou doubt, Big Boston is the most popular Head Lettuce for shipping at this
time. (See illustration.) Pkt. 10c; oz. 15c; y/4 lb. 50c; lb. $\$ 1.50 ; 5$ lbs. $\$ 6.25$ postpaid.

No. 644-White Cabloage Head-Matures in 45 days, Me and head: smooth, compact and firm; always heading and slow to shoot Second-early in maturity. Pkt. 10c; oz. 20c; $1 / 4$ lb. $75 \mathrm{c}$; lb. $\$ 2.50$, postpaid

No. 659 - New York or Wonderful Letuce A grand head lettuce, excellent for furnishing fine, crisp lettuce during the spring. Plants are rich green, growing more than 15 inches in diameter. A
quick seller in the markets because of its crispness and excellent flavor. Pkt $10 \mathrm{c} ; 0 \mathrm{z} .20 \mathrm{c} ; 1 / 4$ lb. $75 \mathrm{c} ; \mathrm{lb} . \$ 2.50$, postpaid.

No. 664-Paul's Hard Head- Matures in 40 days. A very hard heads within a few weeks after planting. Medium sized, light green, oz. $25 \mathrm{c}$; $1 / 4$ ib. $65 \mathrm{c}$; lb., $\$ 2.00$, postpaid.

No. 657-Mignonette- A small, sturdy, all.head Lettuce; the leaves tinged russet. It is very early, hardy, long-standing, and fine for late fall crops in cold.frames. Pkt. 10c; $0 z .20 \mathrm{c} ; 1 / 4 \mathrm{lb}$. 50c; $1 \mathrm{~b} . \$ 2.00$. postpaid.

No. 649-Vadco Iceberg - A beautiful variety, being exceedingly crisp and

Van Antwerp's Succession Collection of 4 Best Head Lettuce No. 9

Here is a splendid collection which will supply you with a succession of fine head lettuce all through the season:

Vadco Big Boston

Mignonette

ONE PACKET EACH Of these 4 choice varieties will be mailed postpaid for $25 \mathrm{c}$

Collection No. 670
New York

Vadco Iceberg

ONE OUNCE EACH Of these 4 choice varieties will be mailed postpaid, for

$60 \mathrm{c}$

Collection No. 673

\section{Van Antwerp's Premuims} Valuable Articles For Every Family

On page 7 we illustrate and describe a varied number of articles of real value which you can get as premiums with your seed order. The articles described are needed by every family. Turn to page 7 now and read about our liberal premium system.

\section{USE THE ORDER FORM AND ORDER BY NUMBER PLEASE} A hard header. Splendid for either open ground planting or for forcing under glass. Heads of conical shape and medium size. Heads tightly folded and blanched to a beautiful white See illustration. Pkt. $10 \mathrm{c} ; 0 \mathrm{oz} .20 \mathrm{c} ; \mathrm{x} / 4 \mathrm{lb}, 60 \mathrm{c} ; \mathrm{lb} . \$ 2.00 ; 5$ 1bs. $\$ 8.50$, postpaid.

No. 633-Early Curled Simpson- Matures in 40 days. Makes a curly, loose green, unspotted. Seed white. Pkt. $10 \mathrm{c} ; 0 z .20 \mathrm{c} ; \mathrm{x} / 4 \mathrm{lb}$. 75c; $1 \mathrm{~b}$. $\$ 2.50$, postpaid.

\section{Other Good Varieties of Lettuce}

$\begin{array}{ll}\text { No. 641-California Cream Butter } & \text { No. 629-Grand Rapids } \\ \text { No. 635-Black Seeded Simpson } & \text { No. 655-May King } \\ \text { No. 647-Hanson } & \text { No. 661-Salamander } \\ \text { Price above 6 varieties: Pkt. 10c; oz. 20c; T/4 lb. 50c; lb. } \$ 1.50 \text {, postpaid. }\end{array}$

\section{Romaine or Cos Lettuce}

No. 659-Paris Cos_- Strong and upright, producing long leaves, which should

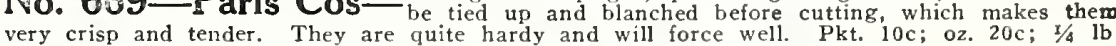
65c: lb. \$2.00, postpaid

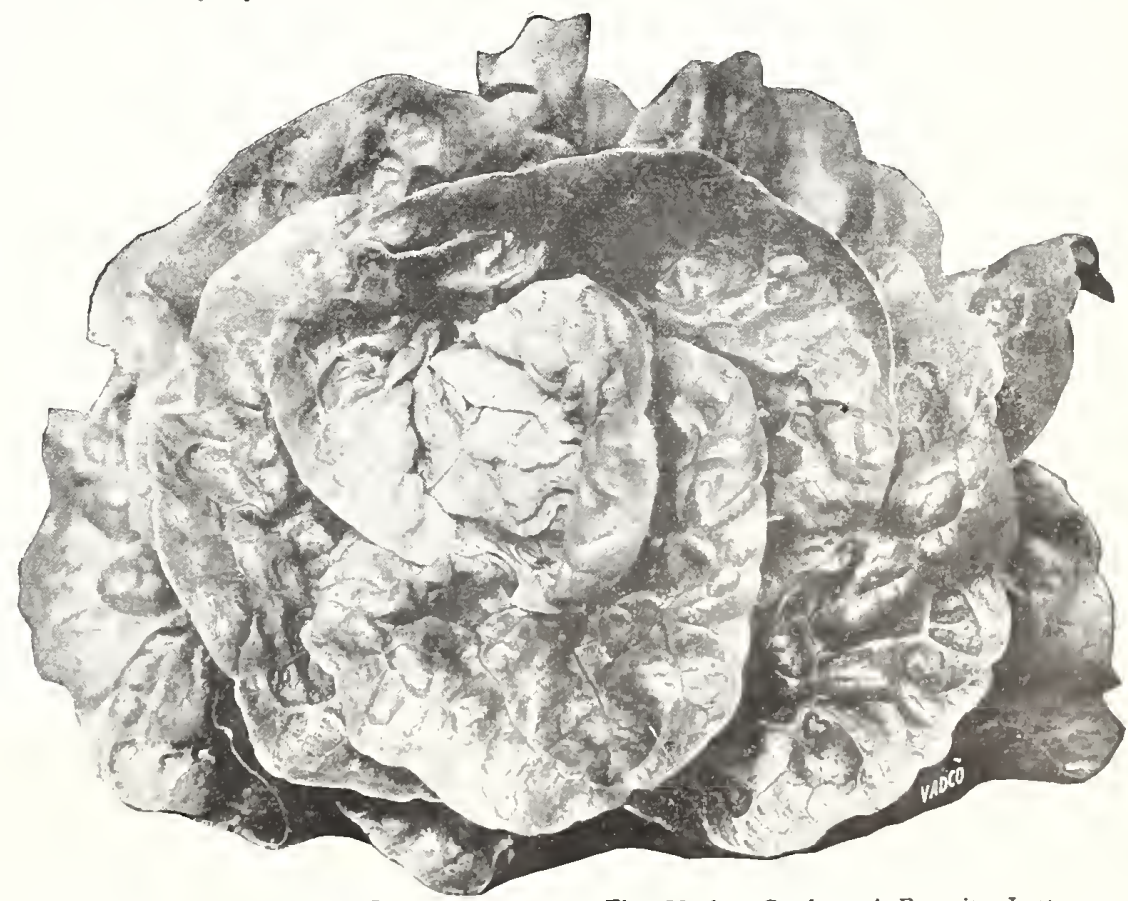

Vadco Selected Big Boston Lettuce No. 639. The Market Gardeners' Favorite Lettuce 


\section{MUSKMELONS or CANTALOUPES}

One ounce to 60 hills. Four pounds to acre

CULTURE-Sow in hills 5 feet apart; dig into each hill, one or two shovelfuls than four plants to grow. They shculd be worked the same as cucumbers until

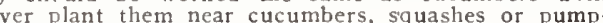

No. 677-Vadco Eden Gem (Green Fleshed) — The re a making variety for the shipper and market gardener as well as the most satisfactor netting helps greatly in resistance to insect attacks. The flesh is green, lusciously small. The average weight of the melon is about one and one-half pounds, and the largest per cent of the crop is of such size as to pack 45 melons to the standard

No. 678-Texas Cannonball Cantaloupe- Mediun in maturround shape. In flavor it is first-class, and its dense netting makes it almost sur and insect-proof, this being an immense advantage where insects are troublesome

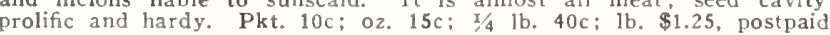

No. 686-Junior Rocky Ford Selected-

and deep, thoroughly covering th

variety, The seed cavity

develop shipping fruits about two weeks before the
$20 \mathrm{c} ; \mathrm{r} / \mathrm{lb}$. 60c; $\mathrm{lb}$. $\$ 2.00 ; 5 \mathrm{lbs}$. $\$ 8.00$, postpaid.

No. 681-Cassaba- Matures in 85 days.

12 to 15 inches in length, heavily ribbed and

oz. $20 \mathrm{c} ; \mathrm{r} / 4 \mathrm{lb}$. 50c; lb. $\$ 1.50$, postpaid.

No. 673-Banana M u s k

Melon- This is the original Musk

from the fragrance of the fruit
Pkt. $10 \mathrm{c} ; 0 \mathrm{zz}, 20 \mathrm{20} ; 1 / 4 \mathrm{lb}$. $50 \mathrm{c}$

lb. $\$ 1.50$, postpaid.

No. 721-Vadco

Rocky Ford -

Matures in 65

dardeners ${ }^{2}$ priat

vate stock. Per-

lect type and
strain of Rocky

Ford M e 1 o

Ford, Colorado

Melon growers

and has been

the vicinity of

gre a t satisfac

is green, thick.

with small cav

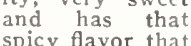

makes a cants

loupe so delici.
ous. The Mel

ons are oval
shaped, slightly

ered with fine

netting, and are

uniform in size

and shape. See

10c; oz. $15 \mathrm{c} ; \mathrm{r} / \mathrm{T}$

$\$ 1.00 ;$
$\$ 4.00 ;$

\begin{tabular}{|c|}
\hline Order \\
Your \\
Seeds \\
by \\
Number \\
Please
\end{tabular}

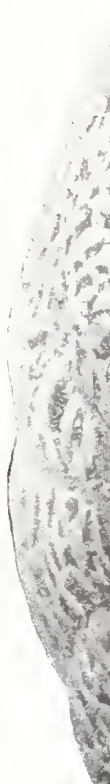

This is our Vadco
Rocky Ford Cantaloupe

No. 721. The seed we offer is the original pedigree true strain.
No. 724-Honey Ball (New) - The Honey Ball Melon is the reBall Cantaloupe and the California Honey Dew Cassaba Melon. Honey Ball resists Ban scald better than most other melons. It averages a little larger than the Rocky
sun sord. It is as round as a teall and has a very thick wall of delicious green meat clear to the rind. The seed cavity is very small. It has a high sugar content and postpaid.

No. 705-Hearts of Gold- Hearts of Gold Cantaloupe combine the heavy netting and thin rind of the Netted Gem type of Rockyford. It is about 25 ,

No. 683-Extra Early Hackensack- Matures in 65 days. A

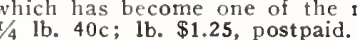

No. 689-Golden Netted Gem- Matures in 70 days. One of the uniform in size and weight, weighing from $11 / 4$ to 1 pounds each; flesh light green No. 701-Vadco Honey Dew_ -8 The average size of the melon is 8 to 12 inches in length, weight 8 to 12 pounds. The skin is very smooth with an occasional net; it is creamy white when ripe; The flesh is an emerald green.
very thick, melting and fine grained. Pkt. $10 \mathrm{c} ; 02.20 \mathrm{c} ; \mathrm{r} / 4 \mathrm{bb}$. $50 \mathrm{c} ; \mathrm{lb}$. $\$ 1.50$; postpaid.

No. 719-Pollock's 10-25— Pollock's type of melon and should take the place of Rocky Ford Pink Meat or Pollock's No. 25. Its merits keeping and shipping qualities and attrac 40c; 1b. \$1.25, post-paid. MELONS

\section{OTHER GOOD MELONS}

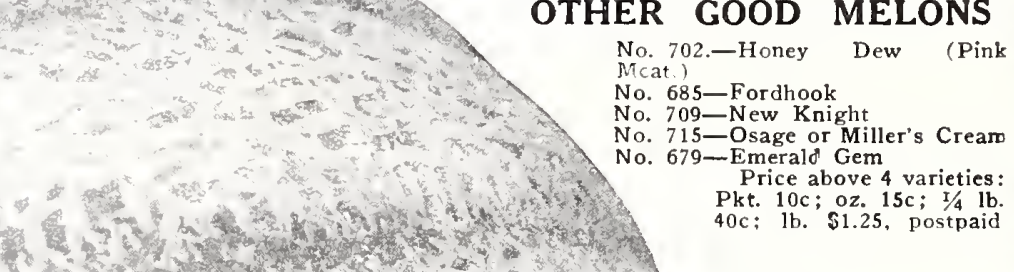

No. 700MellobiteA wonder. ful new canta. loupe illustrated and described on page 11. Pkt $10 \mathrm{c} ; 0 \mathrm{az} .20 \mathrm{c}$ $1 / 4 \quad 1 \mathrm{~b}, 50 \mathrm{c} ; \mathrm{lb}$ $\$ 1.50 ; 5$ lbs. $\$ 7.00$, postpaid.

\section{Special Cantaloupe Collection No. 10 for 25c}




\section{WATERMELON SEED}

VAN ANTWERP'S

FAMOUS FOR

WATERMELONS.

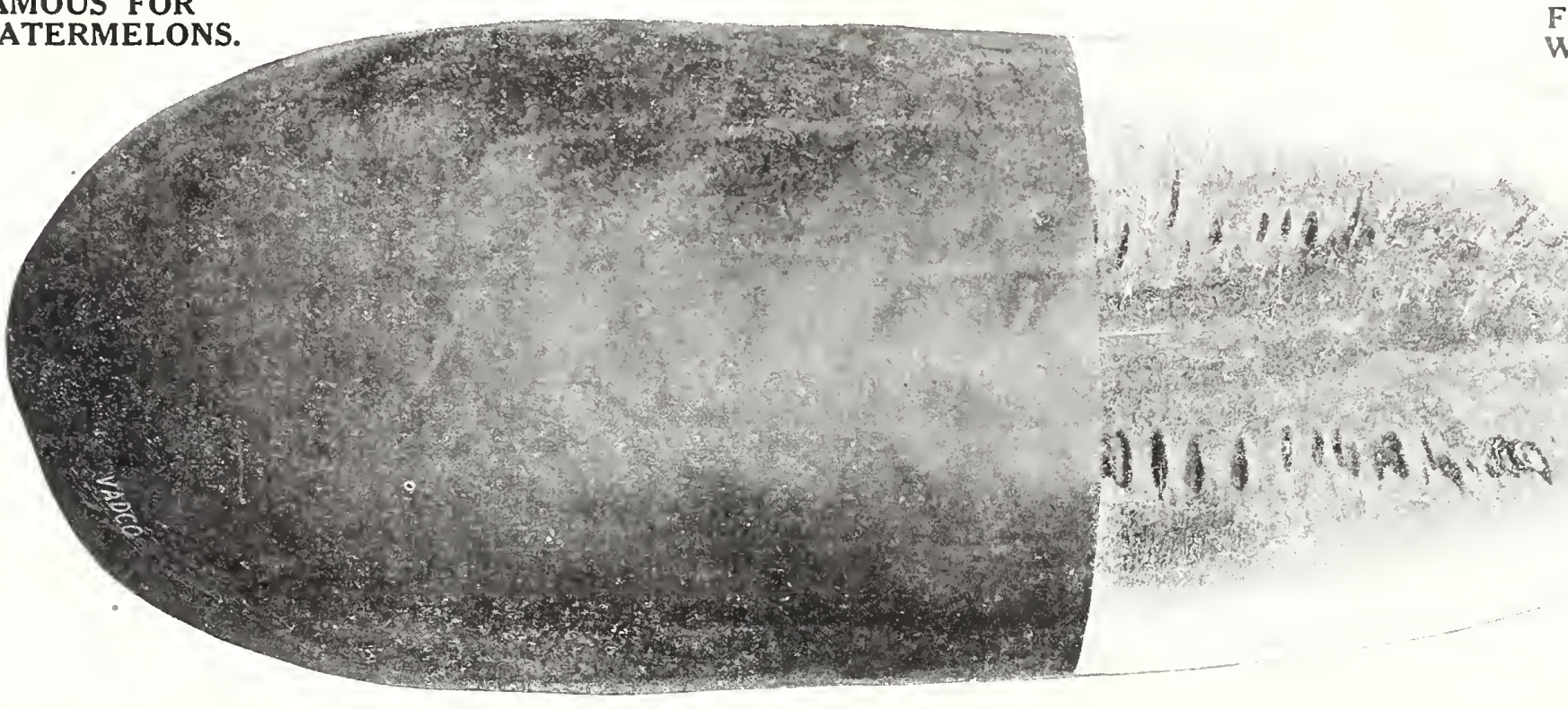

VAN ANTWERP'S

FAMOUS FOR

WATERMELONS.

Van Antwerp's Radio Watermelon No. 736

One Ounce for 30 hills. Four pounds to acre
CULTURE--The same as for Mluskmelon, except that the hills should be not less than 8 feet apart and not over three plants allowed to remain in each shipping is limited, many old varieties having been dropped by growers as useless.

No. 749_Vadco Tom Watson- Matures in 85 days. The South's melon, dark green in color. Melons are long, average large size, splendid shippers and one of the best table quality Melons on the market. Our stock is grown for us with great care on a large plantation where no other MLelons are planted. Pkt. 5c; \$1.00, 5 lbs. $\$ 4.00$, postpaid.

No. 739_Vadco Kleckley's Sweet— We get our seed of this the originator, Mr. Kleckley, which is the only true stock. Matures in 80 days. One of the earliest Melons to ripen and one of the sweetest and best flavored. It is hard to beat; is splendid for home use and market. Large size, handsome 10 to 12 inches through; rind dark green, flesh bright scarlet with broad solid to to inches through; rind dark green; flesh bright scarlet, with broad solid oz. $10 \mathrm{c} ; \mathrm{I} / 4 \mathrm{lb}$. 30c; $1 \mathrm{~b}$. $\$ 1.00 ; 5 \mathrm{lbs}$. $\$ 4.00$, postpaid.

No. 733_Florida Favorite_- Matures in 90 days. An excellent vayet it is as good for shipping as Rattlesnake; more than medium size; colored with crisp. One of the best Mlelons. Pkt. 5c; 0z. 10c; 1/4 lb. 30c; lb. \$1.00, postpaid.

No. 737-Irish Grey_- A distinct and valuable new variety producing conditions than any other variety; the eating quality is unbeatable. The sparklin the Watson. Pkt. 5c; oz. 10c; $1 / 4$ lb. 30c; lb. $\$ 1.00 ; 5$ lbs. $\$ 4.00$, postpaid

No. 752_Porto Rico (Yellow Flesh)_B Be sure to try this fleshed watermelon. The flesh is tender, sugary and delicious flavor. The melon it
oblong in shape and the outer skin is dark green with lighter stripes. Prices: Pkt $10 \mathrm{c} ; 02.15 \mathrm{c} ; 1 / 4 \mathrm{lb}$. 40c: $1 \mathrm{~b}$, $\$ 1.50$, postpaid.

No. 746-New Perfection- Mr. Halbert, a famous Watermelon Perfection Melon. He introduced it about 3 years ago and after careful tests we found it to be a very fine melon and decided to list it in our catalog. The New Perfection is a large melon weighing from 50 to $75 \mathrm{lbs}$. It is oval or oblong int shape, rather thin rind, but very tough, and will not crush or crack when shipped
The flesh is dark red, very sweet and frce from fiber or strings. It is an ideal melos for both home and market and it's heautiful shape and color make it extremely

No. 754_New Stone Mountain_ A beautiful large round melon Stone Mountain is the sweetest of all watermelons and is almost round in shape year deep dark green color and rich scarlet flesh make it a ready seller. It weighs 50 do not recommend it for long distance shipping. It is remarkable for the few seeds it contains and its unusually solid good, rich meat. Give New Stone Mountain extra selected stock. Pkt. $10 \mathrm{c} ;$ oz. $15 \mathrm{c} ; \mathrm{x} / 4 \mathrm{lb} .50 \mathrm{c} ; \mathrm{lb} . \$ 1.50 ; 5 \mathrm{lbs} . \$ 6.50$, postpaid.

No. 735-Halbert Honey - The Halbert Honey is claimed to be the mend it for its rich fruity flavor. It is entirely free of fibrous substances. A really

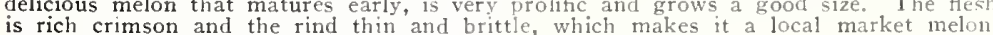
is rich crimson and the rind thin and brittle, which makes
Pkt. 5c;02. 10c; $1 / 4 \mathrm{lb}$. 30c; $1 \mathrm{~b}$. $\$ 1.00 ; 5$ lbs. $\$ 4.50$, postpaid.

No. 727-Alabama Sweets_ Matures in 90 days. Large size, oblong deep red and crisp. Pkt. 5c; oz, 10c; $1 / 4$ lb. 30c; lb. $\$ 1.00$, postpaid.
No. 736-Vadco New Radio- This is unquestionably one of the It meastres 26 to 28 inches in length, is dark green outside striped lighter green. The rind is medium thick and the meat is a hright red, very sweet. It is entirely
free from hard centers and a good long distance shipping variety. New Radio melong

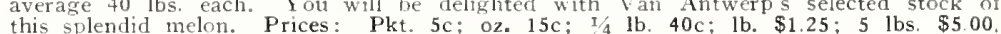
postpaid.

No. 729-Excel - In appearance it strongly resembles the Watson, has a 4.0 to 60 pornds, sincle melons freauently weighing 75 to 80 pounds. Pkt. 5c;02.
$10 \mathrm{c} ; 3 / 4 \mathrm{lb}$. $35 \mathrm{c} ; 1 \mathrm{~b}$. $\$ 1.00$. postpaid.

No. 734-New Wondermelon- In quality and flavor, there is compare with it. It is large and long, in a way resembling the Tom Watson, though it is thicker, and the color is a dark, solid green. The rind is rather thin, but large and pure white, with few to the melon. It has produced well during cevere dry spells and is extremely prolific in average seasons. Pkt. 5c; oz, 10c; $1 / 4 \mathrm{lb}$. , lb, $\$ 1.25 ; 5$ lbs. $\$ 5.00$

No. 745-Georgia Rattlesnake, or Striped GypsyMatures in 85 days. Of large size, light green, with large, dark stripes. Fine market variety. It stands transportation better than most other kinds; a lavorite with market gardeners. The seed we offer of this
us. Pkt. 5c; oz. 10c; $1 / 4,1 \mathrm{~b}, 25 \mathrm{c} ; 1 \mathrm{~b}, 80 \mathrm{c}$, postpaid.

No. 738-Thurmond Gray_Thurmond Gray is a long thick melon Nom melons grow uniturn and pounds and is one of the hest melons for home gardens or market Be sure to ge

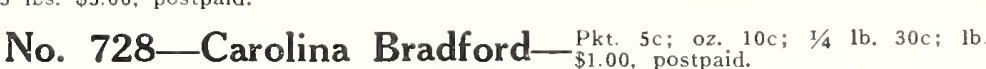

No. 751_Citron- This is a melon for sweet pickles. Do not plant close Inelons. Pkt, 5c; 02, 10c; 1/4 lb. 30c; lb. \$1.00, postpaid.

\section{Van Antwerp's Small Garden
Watermelon Collection No. 11 25C} This collection of selected Watermelon seed contains five packets of the fol Tew Wondermelon, Yadon Kleckley Sweet, Irish Georgia Rattlesnake and Florida Favorite

The five packets for $25 \mathrm{c}$, postpaid.

Order Collection No.

Van Antwerp's Big Garden

Watermelon Collection No. 12$\} 50 \mathrm{C}$ 


\section{ONION SEED}

CULTURE.-In this latitude, the seed should be sown from Sep-
tember 15th to about October 10th; if sown earlier, a good many will throw up seed-stalks, which impairs the keeping quality of the Onion. Sow the seed broadcast; protect the seedbeds by using sacks for covering the beds. When the seed is coming up, in seven or nine days, the cove bas to be removed entirely, but if the weather is dry, the watering has reached the size of a goose quill, they are transplanted into rows whicb may be from 1 to 2 feet apart, according to the method of cultivation thoroughly prepared before setting out the plants.

No. 787-Vadco Prizetaker- The largest and handsomest attain immense size, fifteen inches in circumference being often attained. To reach this size it is necessary to start them early in hotbeds and transplant so they may have a long season to reach their mature size. Pkt. $10 \mathrm{c}$; oz. $25 \mathrm{c} ; 1 / 4$ lb. $85 \mathrm{c}$; lb. $\$ 2.75$, postpaid.

No. 790-Australian Brown-An early and very bardy early, on low, wet grounds to get large bulbs. The skin is thick and the well into spring and much longer than other varieties. Pkt. 10c; oz. 25c: $1 / 4$ lb. $75 \mathrm{c}$; lb. $\$ 2.50$, postpaid.

No. 784-Vadco Red Creole—- The outer skin is a light sweet and tender. Though it is somewhat stronger, perhaps, than the Bermuda, lovers of Onions pronounce its flavor superb. It will keep a
year if properly handled. Pkt. 10c; oz. 25c; 1/4 lb. $75 \mathrm{c} ; \mathrm{lb}, \$ 2.50$, No. 793-White Portugal or Silverskin— Earty ripening, of color. Very mild flavored and extensively grown for pickling. Pkt. 10c; oz. $35 \mathrm{c}$; color. Very mild flavored and $\$ 1.00 ; 1 b . \$ 3.50$, postpaid.

No. 785-Yellow Globe Danvers-A standard sort and one of ient keeper and very productive. Pkt. $10 \mathrm{c} ; 0 z .25 \mathrm{c} ; 1 / 4 \mathrm{lb} .75 \mathrm{c} ; 1 \mathrm{~b} . \$ 2.50$, postpaid.

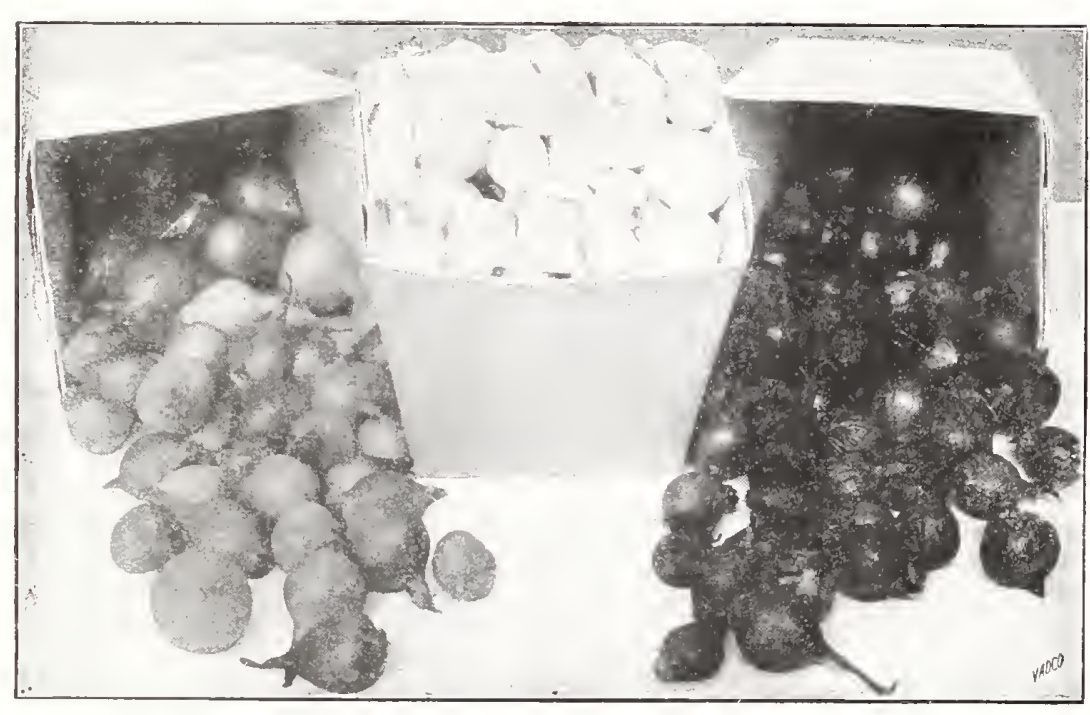

Van Antwerp's Onion Sets Are Re-cleaned.

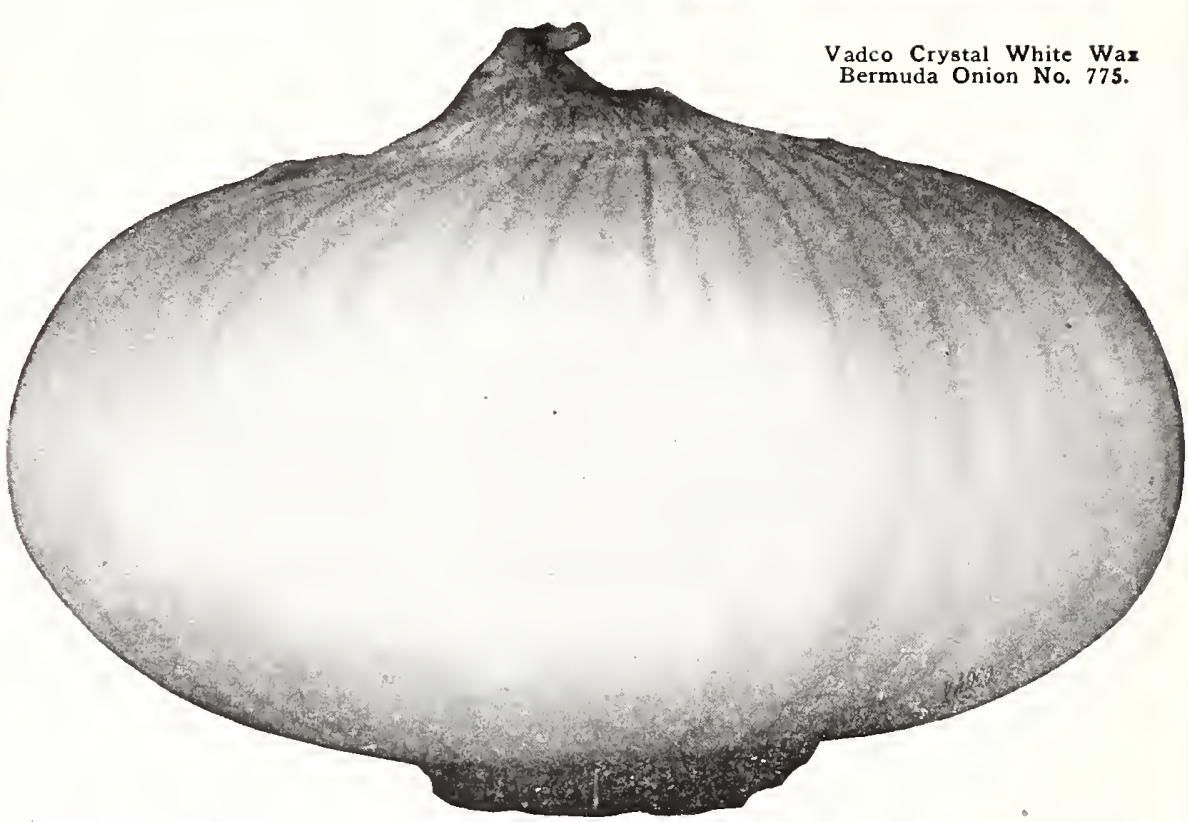

No. 775 - Vadco Crystal White Wax Bermuda (Teneriffe grown)-The only Pure White Bermuda Onion, thus making a ready having all those desirable qualities of the older sorts combined with much more very light seeder. (See illustration.) Pkt. 10c; 1/2 oz, 30c; oz. 50c; $1 / 4 \mathrm{lb}$. $\$ 1.50 ; 1 \mathrm{~b}$. \$5.00, postpaid.

No. 786_-Yellow Bermuda-The standard variety for shipping. flat in shape, growing 3 to 4 inches in diameter, very $s^{\prime} w e e t$ and mild. (Teneriffe grown.) Pkt. 10c; 0z. 25c; 1/4 lb. 85c; lb. $\$ 3.00$, postpaid.

No. 792_Red Bermuda_- Same as White Bermuda, only pale red mild in flavor that they can be eaten raw. (Teneriffe grown.) Pkt. 10c; oz. 25c;

No. 777_Red Wethersfield_Grows to full size the first season deep red color and keeps well. Pkt. $10 \mathrm{c} ; 0 z .25 \mathrm{c} ; 1 / 4 \mathrm{lb} .75 \mathrm{c} ; \mathrm{lb} . \$ 2.50$, postpaid.

\section{ONION SETS}

Where the seasons are so short that large Onions cannot readily be grown about 4 inches apart in drills 12 inches apart, lightly covered, and well cultivated.

No. 778-Silver Skin-Excellent variety for family use. Skin and $50 \mathrm{c}$, postpaid. Not prepaid, $8 \mathrm{lbs}$. (peck), $\$ 1.15 ; 32 \mathrm{lbs}$. (bushel), $\$ 4.00$.

No. 779_ E Ellow Danvers_ Standard variety, globe shaped, large sort. Pint $15 \mathrm{c}$; qt. $30 \mathrm{c} ; 2$ qts. $50 \mathrm{c}$; postpaid.. Not prepaid, 8 lbs. (peck), $\$ 1.15$; Onion Sets prices subject to change.

No. 780-Bermuda Onion Sets— We can supply tbese setu ber. Write for quantity prices in August.

\section{THE CUSTOMER'S OPINION}

Some of my tomato vines were as bigh as my head, and were the comment of all my neighbors.-B. F. Cash, Newark, Arkansas.

Our garden was just fine tbis season and the seels were the be-t we ever planted.-Mrs. W. H. Stafford, Handsboro, Miss.

Tbe seed I ordered from you last spring proved very satisfactory - James H. Jones, Fay etteville, Arkansas.

Your seeds proved the best I bave ever planted.-L. W. Carter, Perdue Hill, Ala.

\section{PREMIUMS}

You can get valuable Premiums when you order

VAN ANTWERP'S SEEDS See Page 7 Now.

\section{OKRA SEED}

CULTURE-A highly esteemed vegetable in the South, and no garden, mall or large, is without it. It is used in making "Gumbo." It is also boiled in salt and water and served with vinegar as a salad. Should not be planted before the ground is warn in spring, as the seeds are apt to rot. Sow in drills, which ought to be 2 to 3 feet apart, and when up, thin out, and leave one or two plants every 12 or 15 inches:

No. 773-Perkins' Mammoth Long-Podded OkraVery productive, pods starting to shoot out within 3 or 4 inches from the bottom of the stalk, and the whole plant is covered with them to the height of a man's head ( 5 to 6 feet). Pods very slim
usually tbe case witb other long, slender sorts.

No. 771 - White Velvel- Matures in 50 days. A great imPlant of medium height, bearing a large crop of white, smooth tender pods, wbich retain their tenderness until nearly full size.

No. 767-Dwarf Green- Matures in 50 days. An extra early If planted for market it will be in demand only up to the time the smooth long-pod varieties come in, as no rough pods sell well when the smooth can
be obtained.

Price all varieties of Okra: Pkt. $5 \mathrm{c} ; 0 \mathrm{z}, 10 \mathrm{c} ; \mathrm{T} / 4 \mathrm{lb} .20 \mathrm{c} ; \mathrm{lb} .50 \mathrm{c} ; 5 \mathrm{lbs}$ a $40 \mathrm{c}$ per lb., postpaid.

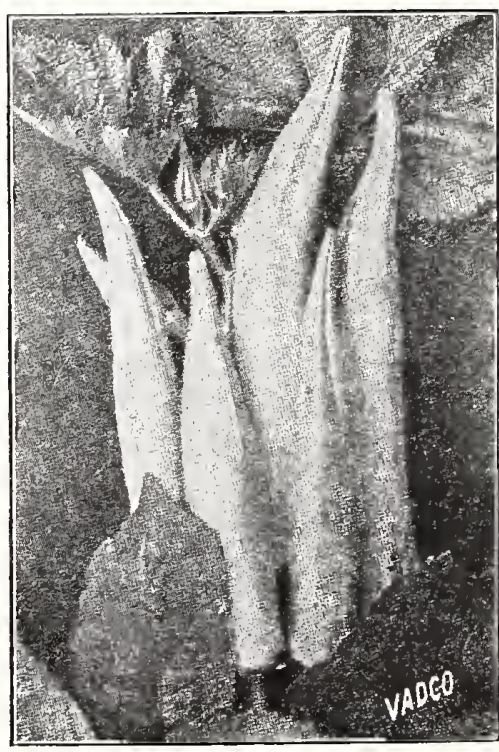

White Velvet Okra No. 771. 

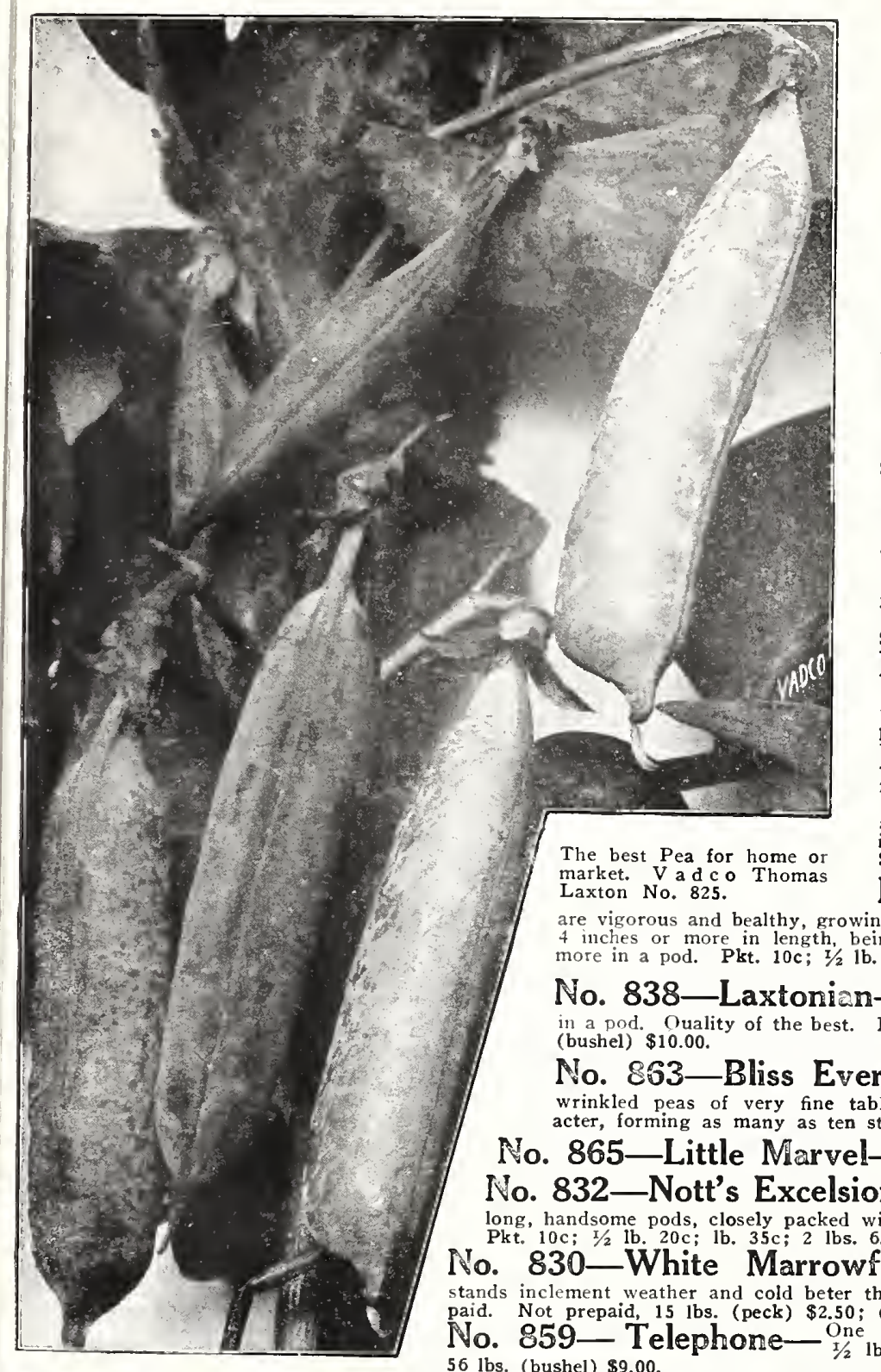

\section{VAN ANTWERP'S GARDEN PEAS}

CULTURE- Two pounds to 100 feet of drill; $1 \mathrm{I} / 2$ bushels to acre. inches deep. Tall-growing varieties should have 3 feet between the rows, while for the very from August till March, as follows: Extra early varieties in August, September and tbe spring. Plant the dwarf and extra early Peas in rich soil; marrowfats do better in only in No. 833_Vadco World's Record_one of the most popular varietie Gradus but much earlier and more productive. Grows about 2 feet high and resembles the 4 to 5 inches in length, broad, pointed type-pods tbat are long and well filled, seven or $\$ 1.50$, postpaid. Not prepaid, 14 et. Prices: Pkt. 10c; $1 / 2 \mathrm{lb} .20 \mathrm{c} ; 1 \mathrm{~b}, 40 \mathrm{c} ; 2$ lbs. $70 \mathrm{c} ; 5 \mathrm{lbs}$. No. 81 - Vadco Eariezt Extra Eary_ It has become the main re. in the South who wish to be first with new peas. It is a smooth sort, with wonderful and in seeded pea that will grow and mature quicker than any other. The vines average about $2 \frac{1}{2}$ to 3 feet in height, just short enough to bear a large crop. (See illustration.) Pkt. $\$ 99.00$. No. 817-Early Alasla_- Matures in 50 days. This is an extra-early Pea, other kind; very fine and prolific; the best flavored Pea among the extra-early smooth. porded kins. postpaid.

No. 825-Vadco Thomas Laxton-The finest pea in cultivation. It fessional growers as well as home gardeners say it is the greatest pea of today. Closely resembles the Gradus or Prosperity, but hardier and slightly earlier. Pods with 7 peas illustration.) Pkt. 10c; 1/2 lb. 25c; 1b. 40c; 2 lbs. $70 \mathrm{c}$, postpaid. Not prepaid, 14 lbs. (peck). No. 821 - Gradus or Prosperity— The earliest, largest-podded and most The best Pea for home or market. V a d co Thoma Laxton No. 825. are vigorous and bealthy, 4 inches or more in length, being as large as the Telephone, and equally well filled with luscinus peas. eight to ten or
more in a pod. Pkt. 10c; $1 / 2$ lb. 20c; lb. 40c; 2 lbs. $70 \mathrm{c}$; postpaid. Not prepaid, $14 \mathrm{lbs}$. (peck) $\$ 3.25 ; 561 \mathrm{bs}$. (bushel) $\$ 12.00$. No. 838-Laxtonian_ One of the earliest dwarf Peas. Vines are vigorous, growing about 18 inches high, in a pod. Ouality of the best. Pkt. $10 \mathrm{c} ; \mathrm{x} / 2 \mathrm{lb} .20 \mathrm{c} ; 1 \mathrm{~b} .40 \mathrm{c} ; 2 \mathrm{lbs} .70 \mathrm{c}$, postpaid. Not prepaid, $14 \mathrm{lbs}$. (peck) $\$ 2.75 ; 56 \mathrm{lbs}$. No. 863_Bliss Everbearing_ The greatest favorite for home gardens and nearby markets. Height of wrinkled peas of very fine table quality Size of peas large to very large Its habit of growth is branching char. acter, forming as many as ten stalks to a single root. See illustration. Pkt. $10 \mathrm{c} ; 1 \mathrm{~b}, 40 \mathrm{c} ; 2 \mathrm{lbs}, 75 \mathrm{c} ; 5$ lbs. $\$ 1.50$, postpaid. No. 865-Little Marvel-Pkt. 10c; bb. 35c; 2 lbs. 65c, postpaid.

No. 832-Nott's Excelsior_Matures in 52 days. Robust and vigorous in growth; inclined to long, handsome pods, closely packed with large peas of fine favor: the base of the stock, producing in profusion Pkt. 10c; 1/2 lb. 20c; lb, 35c; 2 lbs. 65c, postpaid Not prepaid, 14 lbs. (peck) $\$ 2.50 ; 56$ lbs. (bushel) $\$ 9.50$. No. 830-White Marrowfat_Very popular witb the gardeners in this section, who plant this stands inclement weather and cold beter than the early varieties. Pkt. 10c; $1 / 2$ lb. 15c; lb. 30c; 2 lbs. $55 \mathrm{c}$, postpaid. Not prepaid, $15 \mathrm{lbs}$. (peck) $\$ 2.50 ; 60 \mathrm{lbs}$. (bushel) $\$ 9.00$.

No. 859 - Telephone-One of the most productive 56 lbs. (bushel) $\$ 9.00$.

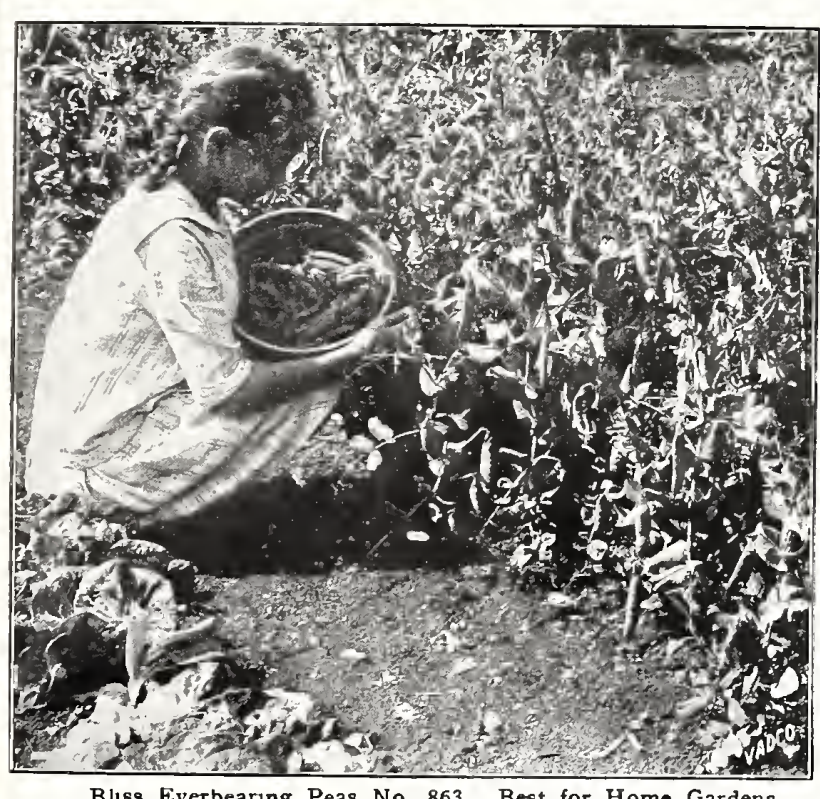

Blıss Everbearıng Peas No. 863. Best for Home Gardens

No. F101-Sugar Crowder Peas-For Table These delicious and heavy bearing cream Sugar Crowders are purposes. Grows upright, bushy, and ordinarily needs no support. Pli on all the vining variety. Not prepaid, io lb. lots or over at $15 \mathrm{c}$;b.
No. 845-Dwarf Telephone- Excellent variety; large, well-filled pods; Pkt. 10c; $1 / 2$ lb. 20c; 1b. 40c; 2 lbs. 70c, postpaid. Not prepaid, 14 lbs. (peck) $\$ 2.50$; 56 lbs. (bushel) $\$ 9.00$. No. 857-Champion of England-Pkt. $10 \mathrm{c} ; 1 / 2 \mathrm{lb} .20 \mathrm{c} ; 1 \mathrm{~b} .35 \mathrm{c}$; No. 813-Prolific Early Market_L Large, bandsome pods, similar in shape prolific. Pods $2 x / 2$ inches long, blunt end, light green, Height, 30 inches. Very
largely used for fall planting. Pkt 10c; $1 / 2$ lb. 20c; 1 lb. $40 \mathrm{c} ; 2$ lbs. 65 , postpaid. No. 861-Mammoth Melting Sugar-Vines grow about 4 higb; very productive. Pods average 5 to 6 incbes in length and $11^{1 / 2}$ inches in width; broken cooked same as string beans. Pkt. 10c; 1/2 lb. 25c; lb. 45c; 2 lbs. 90c, postpaid

\section{SUPERB GARDEN PEAS Our Succession Collection}

The four varieties you get

\author{
Vadco Earliest Extra Early Telephone \\ Early Alaska \\ Gradus
}

\section{ONE PACKET EACH}

Of the above 4 Peas for succession will be mailed postpaid for

\section{$25 c$}

ONE-HALF LB. EACH

Of the above 4 Peas for succession will be mailed postpaid for

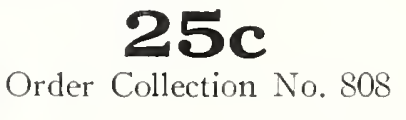

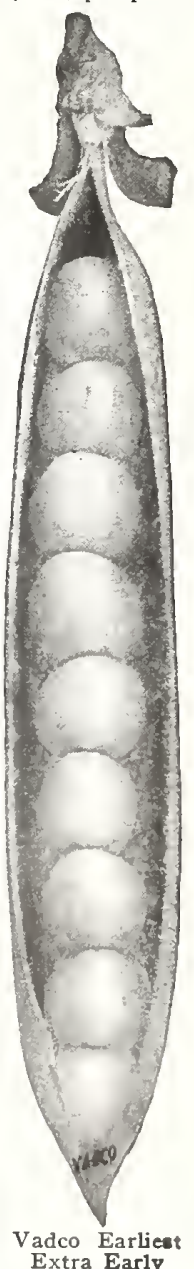

Extra Early 


\section{CHOICE PEPPER SEED GRO GRONA SPECIALLY}

CULTURE-Plant in boxes in February or March, cover $1 / 4$ inch deep, and transplant outside in May,
18 inches apart, in 2 or 3 -foot rows. When the ground becomes warm, sow outside and transplant. Cultivate well and keep free of weeds. Hen manure, or a good garden fertilizer, if worked into the soil when No. 889-Vadco World Beater- This is, without doubt, the finest large pepper yet intro. Fing, fully as early as Ruby King and similar in shape, but broader at blossom end, almost the size of Chinese Giant and far more prolific, some plants producing as many as twenty-four marketable peppers, exceptionally mild, can be eaten raw without fear of burning. Color of fruit green at first, turning to a beautiful shade o scarlet. Flesh thick, which $\$$ oz, 20c; $35 \mathrm{c} ; 1 / 4 \mathrm{lb} . \$ 1.25 ; 1 \mathrm{~b} . \$ 4.50$, postpaid.

No. 879-Royal King- Royal King is very thick-meated, averaging about as thick again as the weet and free from pungency. No. 869-Crimson Giant-

(1) shape. The plant is vigorous and upright, growing $2 \mathrm{I} / 2$ to 3 feet high, larger than
more productive. Pkt. 10c; $1 / 2$ oz. $25 \mathrm{c} ; 0 \mathrm{oz} .45 \mathrm{c} ; \mathrm{I} / \mathrm{lb}$. $\$ 1.50: 1 \mathrm{~b}$. $\$ 5.50$, postpaid.

No. 883-Ruby King- Natures in 120 days. An exceedingly large and handsome Pepper of mild by 9 to 12 inches in circumference. Can be sliced for salads or eaten with salt and vinegar, like tomatoes and cucumbers. Pkt. 10c; $1 / 2$ oz. $25 \mathrm{c} ; 0 z .40 \mathrm{c} ; 1 / 4$ 1b. $\$ 1.25 ; 1 \mathrm{~b} . \$ 4.00$, postpaid.

No. 881_Ruby Giant_- Flesh exceedingly sweet, and mild enougl to eat raw. It matures early, more productive and an excellent large sweet pepper for stuffing. Pkt. 10c; $1 / 2$ oz. 25c; oz. 40c; $1 / 41 \mathrm{~b}$. $\$ 1.25$ No. 877 - Vadco Pimiento- It can be eaten raw like an apple: can be stuffed with meat and time of year. It has thick, firm flesh which permits its being scalded and peeled. Should be in every family garden in the South because it is delicious stuffed with salads. Pkt. 10c; oz, 30c; $1 / 4$ ib. $\$ 1.00 ;$; l $\$ 3.75$, post paid. No. 867-Vadco Chinese Giant_- Matures in 140 days. Mammoth size, splendid shape, large fruits. Pkt. 10c; 1/2 oz. 30c; 0z. 50c; I/4 lb. $\$ 1.75$; lb. $\$ 6.00$, postpaid. plants are loaded with splendid No. 876-Sweet Spanish Monstrous- Matures in 125 days of cylindrical form; the thick-fleshed. Pkt. 10c; $1 / 2$ oz. 25c; oz. 40c; 1/4 lb. $\$ 1.25 ; 1 b . \$ 4.00$, postpaid.

No. 875-Long Red Cayenne- statures in 110 days, Fruit from 3 to 4 inches long, very No. 891 - New Golden Dawn Sweet Pepper- Matures in ${ }^{1 / 10}$ days. Color, bright
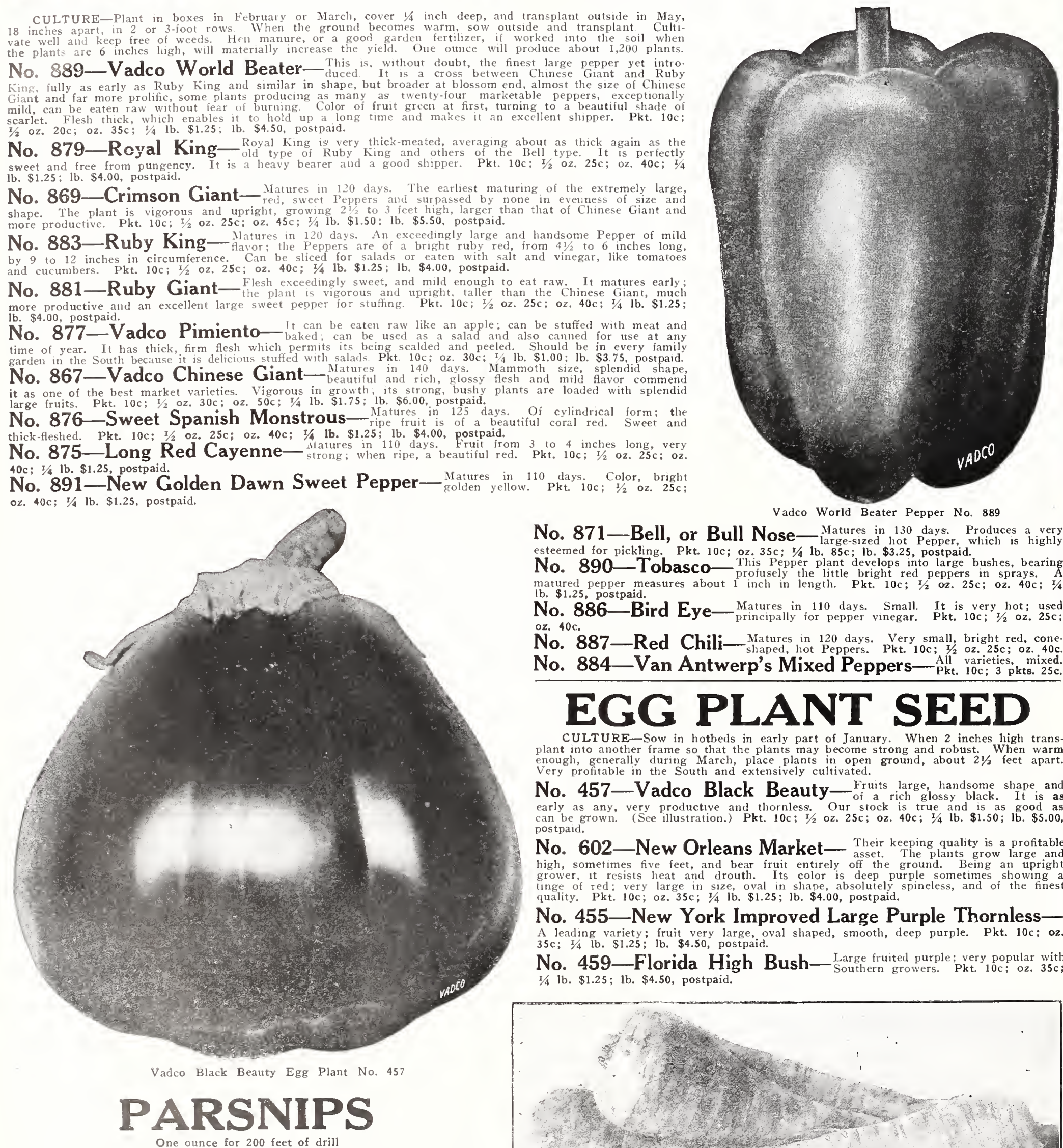

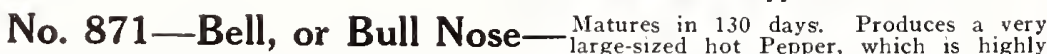

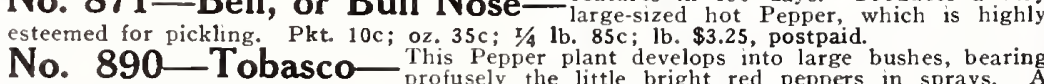

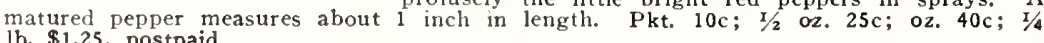

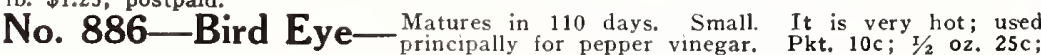
No. 887 -Red Chili- Matures in 120 days. Very small, bright red, cone

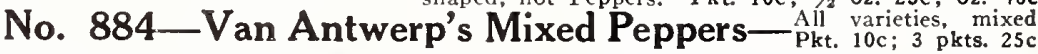

\section{EGG PLANT SEED}

CULTURE-Sow in hotbeds in early part of January. When 2 inches high trans plant into another rame so that the plants may become strong and robust. When warm

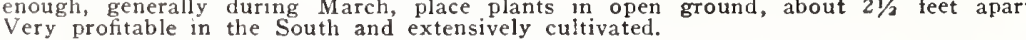

No. 457-Vadco Black Beauty_- Fruits large, handsome shape and early as any, very productive and thornless Our stock is true and is as good as can be grown. (See illustration.) Pkt. 10c; $1 / 2$ oz. 25c; oz. 40c; $1 / 4 \mathrm{lb}$. $\$ 1.50 ; 1 \mathrm{~b} . \$ 5.00$, No. 602_New Orleans Market__ Their keeping quality is a profitable ho. 602 asset. The plants grow large and

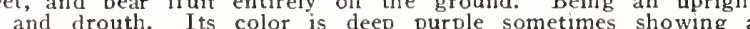
tinge of red: very large in size, oval in shape, absolutely spineless, and of the finest No. 455-New York Improved Large Purple ThornlessA leading variety; fruit very large, oval shaped, smooth, deep purple. Pkt. 10c; oz. No. 459_Florida High Bush—Large fruited purple; very popular with $1 / 4$ 1b. $\$ 1.25 ; 1 b . \$ 4.50$, postpaid.

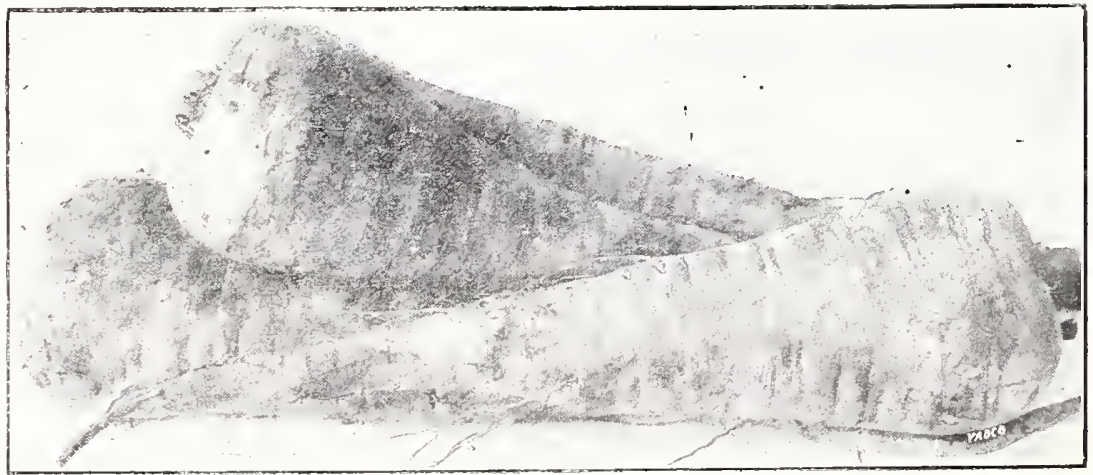

No. 807-Vadco Hollow Crown_- Rich, very sweet flavor,

ready for use in 80 to 85 days. Roots are smoot
long by 3 inches across the shoulder; tender and
Pkt. $10 \mathrm{c} ;$ oz. $15 \mathrm{c} ; \mathrm{T} / \mathrm{lb}$. $35 \mathrm{c}: \mathrm{lb}$. $\$ 1.25$, postpaid.

Vadco Hollow Crown Parsnips No. 807 


\section{PUMPKINS FOR THE SOUTH}
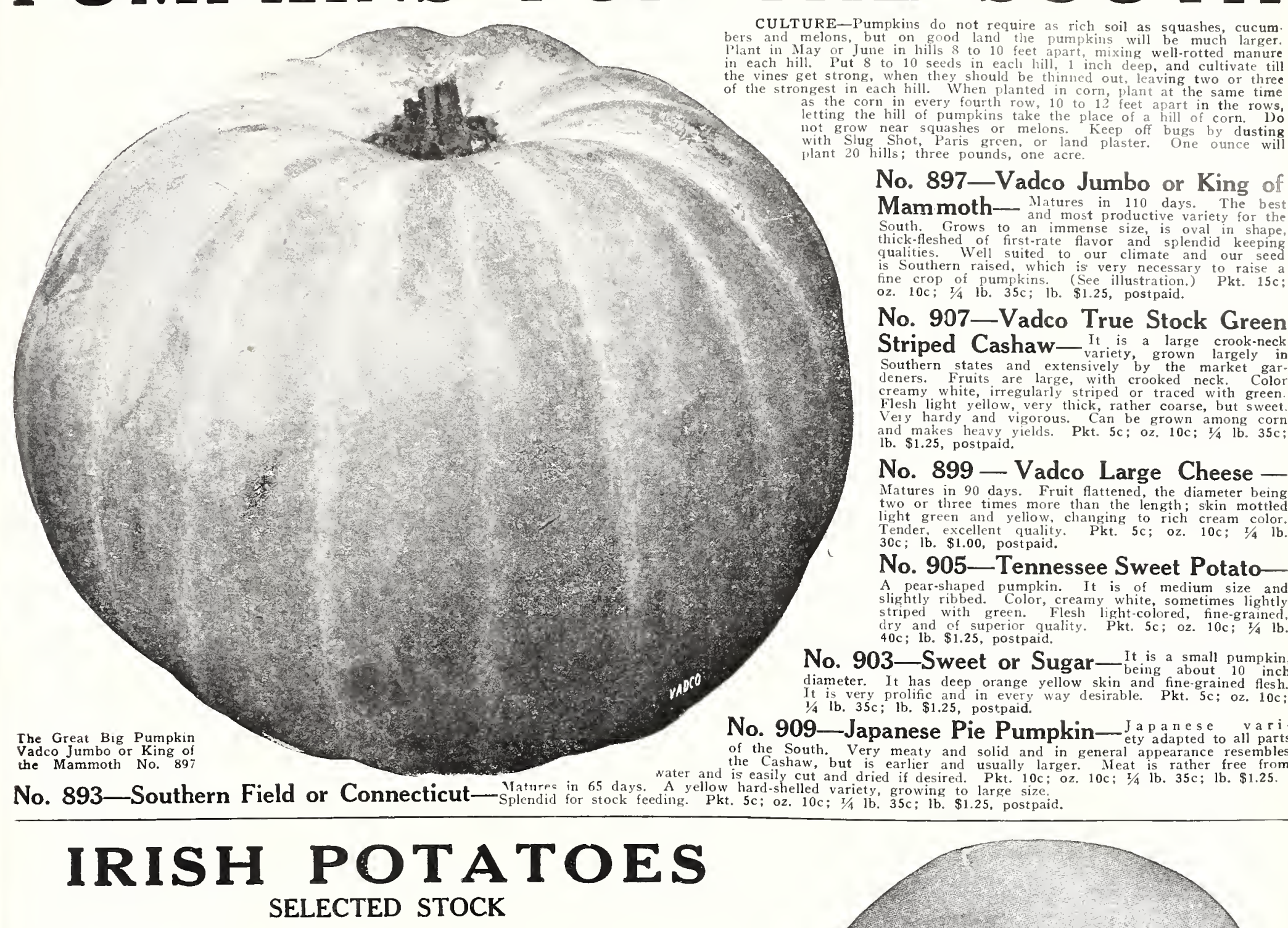

No. 910-Vadco Bliss Triumphs, or Red Bliss- $\begin{gathered}\text { It is one of the earliest kinds } \\ \text { grown and }\end{gathered}$ The tubers are round and uniform in shape, eves slightly depressed and of a beautiful bright red The tubers are round and uniform in shape, eyes slightly depressed and of a beautiful bright red
color. It is one of the hardiest varieties known, and is not susceptible to rot, scab or disease; in color. It is one of the hardiest varieties known, and is not susceptible to rot, scab or disease; in $7 \mathrm{I} / 2$ lbs. (1 $1 / 2$ peck) $65 \mathrm{c} ; 15 \mathrm{lbs}$. (peck) $\$ 1.10 ; 60 \mathrm{lbs}$. (bushel) $\$ 3.50 ; 150-\mathrm{lb}$. bag $\$ 7.75$. Not prepaid.

No. 911-Early Rose- This standard variety has been a great favorite with planters

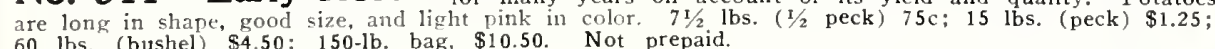
No. 912-Irish Cobbler- The Irish Cobbler is one of the most popular of the early No. 912quality, making it most desirable for the best trade. It is a vigorous grower, ripens uniformly ur cusers with $60 \mathrm{lbs}$. (bushel) $\$ 4.00 ; 150 \mathrm{-l}$ b. bag, $\$ 9.00$. Not prepaid.

PRICES SUBJECT TO CHANGE WITHOUT NOTICE. WRITE FOR

NOTE.-Disinfect your potatoes with Semesan before planting-See Page 57.

\section{Asparagus Seed and Roots}

No. 897-Vadco Jumbo or King of Mam moth- Matures in 110 days. The best

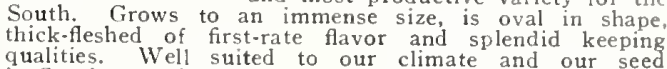
qualities. Well suited to our climate and our seed fine crop of pumpkins. (S.ee illustration.) Pkt. 15c: No. 907-Vadco True Stock Green Striped Cashaw- It is a large crook-neck Southern states and extensively by the market gar-
deners. Fruits are large, with crooked neck deners. Fruits are large, with crooked neck. Color
creamy white, irregularly striped or traced with green Flesh light yellow, very thick, rather coarse, but sweet eety hardy and vigorous. Can be grown among corr
and makes heavy yields. Pkt. 5c; 02, 10c; $1 / 4 \mathrm{lb}$. $35 \mathrm{c}$ : No. 899 - Vadco Large Cheese Matures in 90 days. Fruit flattened, the diameter being Matures in 90 days. Fruit flattened, the diameter being
two or three times more than the length; skin mottled
likgt Tender excellent quality. Pkt. 5c; oz. 10c; $1 / 4$ lb. No. 905-Tennessee Sweet PotatoA pear-shaped pumpkin. It is of medium size and slightly ribbed. Color, creamy white, sometimes lightly dry and of superior quality. Pkt. $5 \mathrm{c} ;$; $02.10 \mathrm{c} ; \mathrm{r} / \mathrm{lb}$.
$40 \mathrm{c} ; 1 \mathrm{~b}$. \$1.25, postpaid.

No. 903-Sweet or Sugar- It is a small pumpkin,

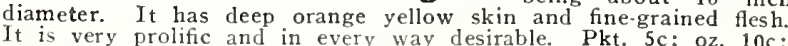
No. 909-Japanese Pie Pumpkin- J J ety a a nape vari of the South. Very meaty and solid and in general appearance resembles
the Cashaw, but is earlier and usually, larger

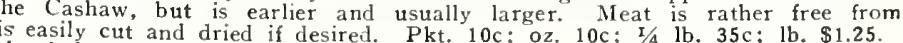
kt. $5 \mathrm{c} ; \mathrm{oz} .10 \mathrm{c} ; \mathrm{t} / \mathrm{l} \mathrm{lb}, 35 \mathrm{c} ; \mathrm{lb}$. $\$ 1.25$, postpaid.
.

\section{CULTURE-The ground should be well manured and prepared before either the} roots or seeds are planted. Plant the seed in early spring; soak over night in water. be cultivated with a plow; put from four to five seeds in each hill; when well up thin out to two plants. The following winter, when the stalks are cut off, cover
with a heavy coat of well-rotted manure and a sprinkling of salt; fish brine will

No. 16-New Pedigreed Washington- Originally developed by of Agriculture, further selected and improved, It is rust-resistant, particularly vig. orous, and of wonderful quality. The shoots are large, straight, dark green in color and with a heavy purple over-tone; the tight of the ground. Pedigreed Washington Asparagus stands allead of all

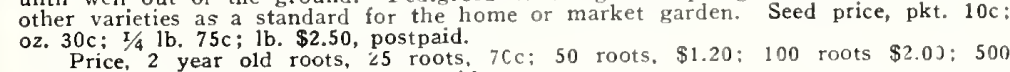
for $\$ 6.50 ; 1,000$ for $\$ 11.50$, postpaid.
No. 15-Palmetto Seed_An excellent variety, especially adapted to

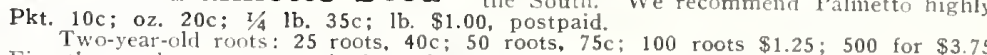

\section{ARTICHOKES}

CULTURE-Every fall the ground should be manured and spaded, or plowed between them; at the same time the suckers should be taken off. Sow in drills
during winter or early spring 3 inches apart and 1 foot from row to row and cover
with about $1 \frac{1}{2}$ inches of earth. The following fall the plants can be transplanted.

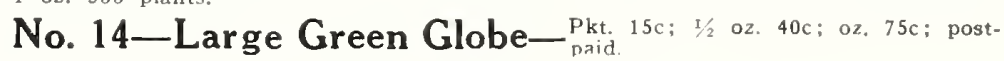




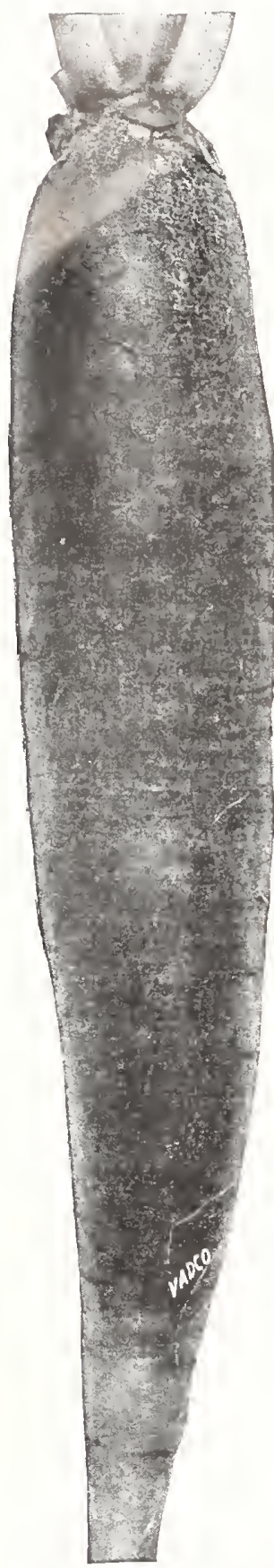

Cincinnatı Market Radisb No. 935 . The best long

\section{BIG RADISH Collection No.17}

This collection contains one packet each of the 4 following choice sorts:

EARLY SCARLET GLOBE CINCINNATI MARKET FRENCH BREAKFAST LONG WHITE ICICLE

The 4 full size packets mailed postpaid for $15 \mathrm{c}$.

One full ounce of the 4 varieties postpaid for $40 \mathrm{c}$.

Order collection No. 17.

\section{RADISHES \\ YOU CAN GROW THEM ALL THE YEAR ROUND IN THE SOUTH}

One ounce for 100 feet of drill

CULTURE-Sow broadcast, in rich, mellow soil, or among other vegetables, where they will ripen oon, and can be removed to give growing room. The red varieties may be sown every month of the are the best for summer sowing, while the Black Spanish should be sown in October and November.

No. 914_Vadco Southern Market_Matures in 25 days. A fine forcing Radish of rower (Stock selected Should becoming pithy; the most desirable Radish for fur upply. (See illustration.) Pkt. $10 \mathrm{c} ; 0 z, 15 \mathrm{c} ; \mathrm{r} / 4 \mathrm{lb} .30 \mathrm{c}$; lb. $\$ 1.00,5$ lbs. $\$ 4.00$, postpaid.

No. 923_-Scarlet Turnip White-Tipped_- Matures in 20 days. A very early Radisb, beautiful, deep scarlet color, with white tips; small tops. Selected stock. Pkt. 5c; oz. 10c; 1/4 1b. 30c; No. 919-Early Scarlet Globe One of the best for forcing or for early outdoor sowing. Porect in shape and color. Roots are oval or oliveshaped, deep scarlet in color, mild, crisp and tender flesh. Small tops. They are ready for market in 20 to No. 935-Cincinnati Market_It is the standard market radish in a number of Southern No. nd of delightful flavor. (See illustration.) Pkt. 5c; oz. $10 \mathrm{c} ; \mathrm{s} / 4 \mathrm{lb}$. $25 \mathrm{c} ; \mathrm{lb} .75 \mathrm{c} ; 5 \mathrm{lbs}$. \$3.00, postpaid. No. 941_Vadco White Icicle_Matures in 24 days. It produces beautiful, long white Toots, extremely early, hence decidedly popular for forc ing and a splendid sort for light, deep soil for out of doors, Ilt retains its excellent qualities longer than $85 \mathrm{c}$, postpaid.

No. 961_Long White Vienna_Excellent variety, growing to good size without be uicy, and agreeably snappy. It does best on rich and moist soil. Pkt. 5c; oz. $10 \mathrm{c} ; \mathrm{I} / 4 \mathrm{lb}$. 25c; lb. $75 \mathrm{c}$. No. 927-Early Scarlet Turnip_- Matures in 25 days. Small, round; the favorite kind Pkt. 5c; oz. 10c; 1/4 lb. 25c; lb. 75c, postpaid.

No. 945_White Strasburg_Even when comparatively small this variety is in good the roots are four to six inches. Pkt. $10 \mathrm{c} ; \mathrm{oz} .15 \mathrm{c} ; \mathrm{I} / 4 \mathrm{~b}, 30 \mathrm{c} ; \mathrm{lb}$. $\$ 1.00$, postpaid.

No. 932_Early Long Scarlet_- Matures in 35 days. This is a desirable variety; of a No. 931_French Breakfast_ Matures in 22 days. A handsome Radish, scarlet, with the $1 / 4$ lb. $30 \mathrm{c}$; lb. $85 \mathrm{c}$, postpaid.

No. 934_Chartier's Long_ Matures in 35 days. A long Radish, described as deep crimwhite. Pkt. 5c;0z, $15 \mathrm{c} ; \mathrm{Y} / 4$ lb. 30c; lb. $\$ 1.00$, postpaid.

No. 960 - White Olive-Shaped_ Matures in 24 days. Well adapted for forcing; oblong tender, crisp, brittle. Pkt. $5 \mathrm{c}$; oz. $10 \mathrm{c} ; 1 / 4 \mathrm{lb}, 30 \mathrm{c} ; \mathrm{lb} . \$ 1.00$, postpaid.

No. 944_Golden Globe_ Matures in 30 days, Stands the heat better than most kinds. No. 953 -Chinese Rose- Matures in 55 days. Of a half-long shape, bright rose color. No. 959 -Black Spanish_(Winter). Matures in 70 days. Tbis is sown during the fall yinter. it is olive-shaped, solid, and stands consider No. 947-Giant White Stuttgart—-An oval-shaped white variety, used for planting in oz. $15 \mathrm{c} ; \mathrm{I} / 4 \mathrm{lb} .40 \mathrm{c} ; \mathrm{lb} . \$ 1.50$, postpaid. Some of all the leading varieties, long, short, round, , leading varieties, z. $10 \mathrm{c} ; 1 / 4$ lb. $25 \mathrm{c}$; lb. $65 \mathrm{c}$, postpaid.

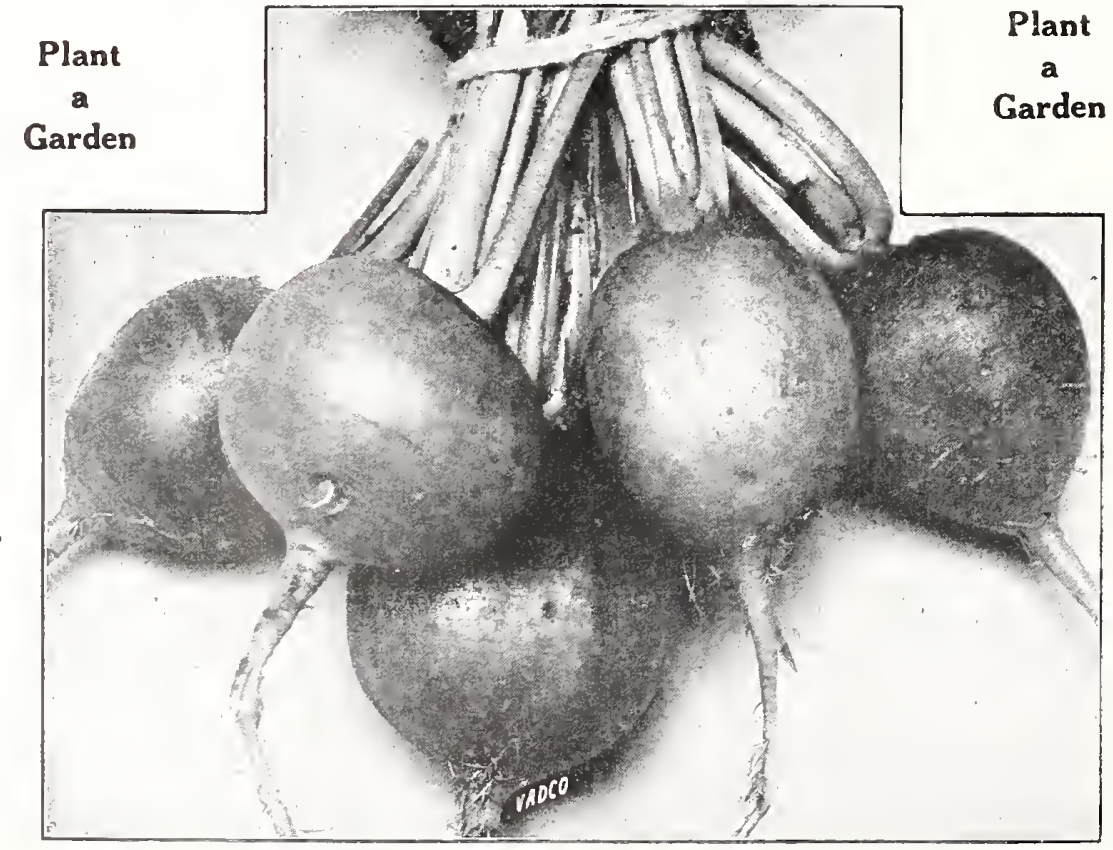

Vadco Southern Market Radish No. 914. The finest of all the Scarlet Globe Radishes.

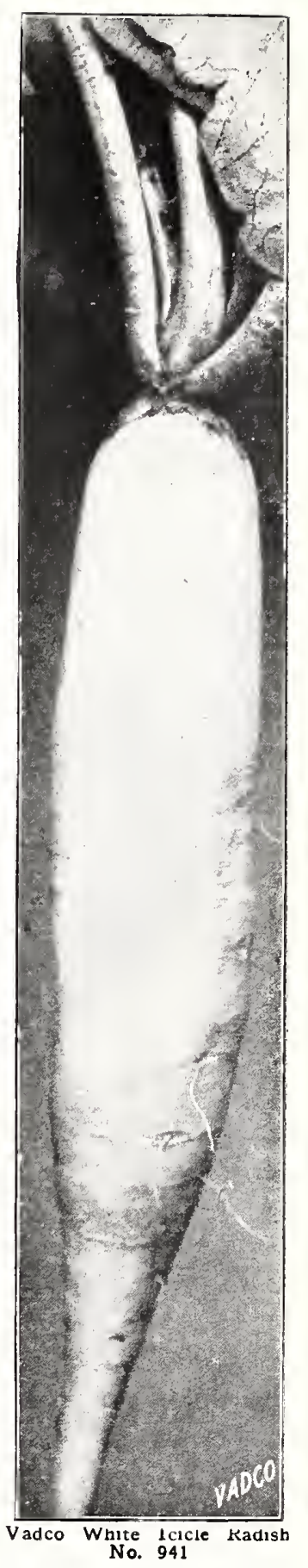

RHUBARB or PIE PLANT CULTURE-Plant in March or April in a shaded place, and when a few and in high thin to 12 inches apart. transplant the fall or following spring, over the 4 feet apart; a barrel placed rom the sunts gives ideal protection tender stalks. The best stems are pro duced the second year, but it continues to produce for several years. Apply No. 963 - Myati's Victoria Seed- The best Rhubarb RTubarb Roots, VictoriaExtra large clumps. Each 20c; $1 / 2$ doz. Horseradish $\mathrm{R}$ o o is As soon as the ground can be worked in the spring set the roots in rows 6 inches apart, and about 6 inches apart in the rows; very little cultivation is roots as will be required for many winter as will be required for you a barrel and fill with sand. Prices: Maliner Kren variety By mail posi paid, 25 roots or sets, $65 \mathrm{c} ; 50$ for $\$ 1.10$. 100 for $\$ 2.00$ 


\section{SUMMER BUSH SQUASH VAN ANTWERP'S SELECTED VARIETIES FOR HOME GARDENS OR MARKET}

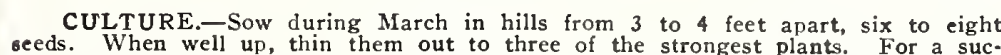
cession, then well up, thin them out to three of the strongest plants. For a succoon as the first of February; but it is best to wait until the ground gets warm.

No. 983_-Vadco Mammoth White Bush-A marked im. the Early White Bush, being nearly double the size and more regular in shape. Early, uniform and prolific; has beautiful clear white skin and flesh and grows 10 to 12 inches in diameter. Fine for family gardens and nearby markets. (See illus. Pkt. Sc; oz. $10 \mathrm{c} ; 1 / 4 \mathrm{lb}$. 35c; lb. $\$ 1.25 ; 5$ lbs. $\$ 5.00$, postpaid.

No. 981-Early Whise Bush or Patty-Pan- Matures in 44 light cream; flat, scallop shape, growing in bush form. Pkt. $5 \mathrm{c} ; 02.10 \mathrm{c} ; \mathrm{H} / \mathrm{lb}$. $30 \mathrm{c}$;
$\mathrm{lb} . \$ 1.00 ; 5 \mathrm{lbs}$. $\$ 4.00$, postpaid.

No. 979-Golden Summer Crookneck-Matures in 44 days. mer bush sorts, of a bright yellow color, very warted, early, prolific, and of fine lbs. $\$ 5.00$, postpaid.

No. 982-Small Yellow Summer Crookned orange yellow color and covered with watty excrescences. It makes an excellent
shipper, is fine grained and of good quality, especially desirable for its rich, buttery to market gardeners in Florida. Pkt. 5c; oz. $10 \mathrm{c} ; 1 / 4 \mathrm{lb}$. 35c; $1 \mathrm{~b}$. $\$ 1.25 ; 5 \mathrm{lbs}$. $\$ 5.00$, post paid.

No. 989_- Delicata_ Tbe favorite Squash for kitchen gardens on account can be stored for a long time without any great trouble. Fruit is yellow, splashed with green; very solid and heavy, sweet, ricbly flavored. Pkt. 5c; oz. $15 \mathrm{c} ; 1 / 4 \mathrm{lb}$. \$1.so, postpaid

No. 985-Boston Marrow- Most popular running yariety. A very medium to large size oval shape, and thin skin. It is generally used for canning and making pies. The fruits when ripe are bright orange with a shading of ligh cream color. Pkt. 10c; 0z. 15c; $1 / 4$ lb. 35c; 1b. \$1.25, postpaid.

No. 997-Italian Cocozelle- A summer variety of bush habit; fruits 5 incbes in diameter, furrowed with 5 ribs, color dark green, marbled with yellow and dark green stripes, quality fine. Pkt. $10 \mathrm{c} ; 0 z, 15 \mathrm{c} ; \mathrm{r} / 4 \mathrm{lb} .40 \mathrm{c} ; \mathrm{lb}$. $\$ 1.50$,

No. 1001 -Vegetable Marrow-Matures in 60 days. The favorite the time the blossom drops until matured. Fruit, when matured, about 12 inches ore guite ripe, tender and delicious. Plet $10 \mathrm{c}$ .50 , post paid.

No. 995-Hubbard_ Matures in 60 days. The popular variety for dry, rich, sweet flavor, fine keeper. Pltt. 5c; oz. $15 \mathrm{c} ; \mathrm{r} / 4 \mathrm{lb}$. 35c; lb. $\$ 1.25$, postpaid.

No. 991_Zucchini Squash— This variety is commonly known as the is piquant in flavor, very tender and delicious. Italian Squasb. It grows long and is piquant in flavor, very tender and delicious. Every bome garden should have a few
of this splendid variety as it's easy to grow and a very beavy yielder. Prices: Pkt. 10c; oz. $15 \mathrm{c} ; 1 / 4 \mathrm{lb}$. $40 \mathrm{c} ; \mathrm{lb}$. \$1.25, postpaid.

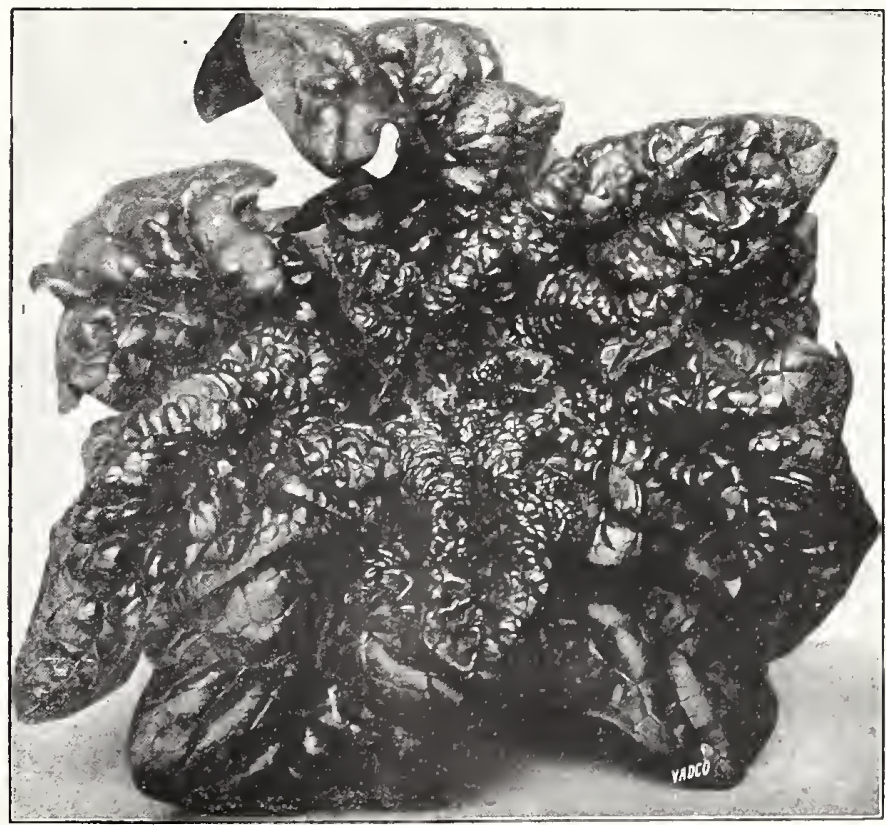

Virginia Savoy Spinach No. 978. The new blight resistant kind,

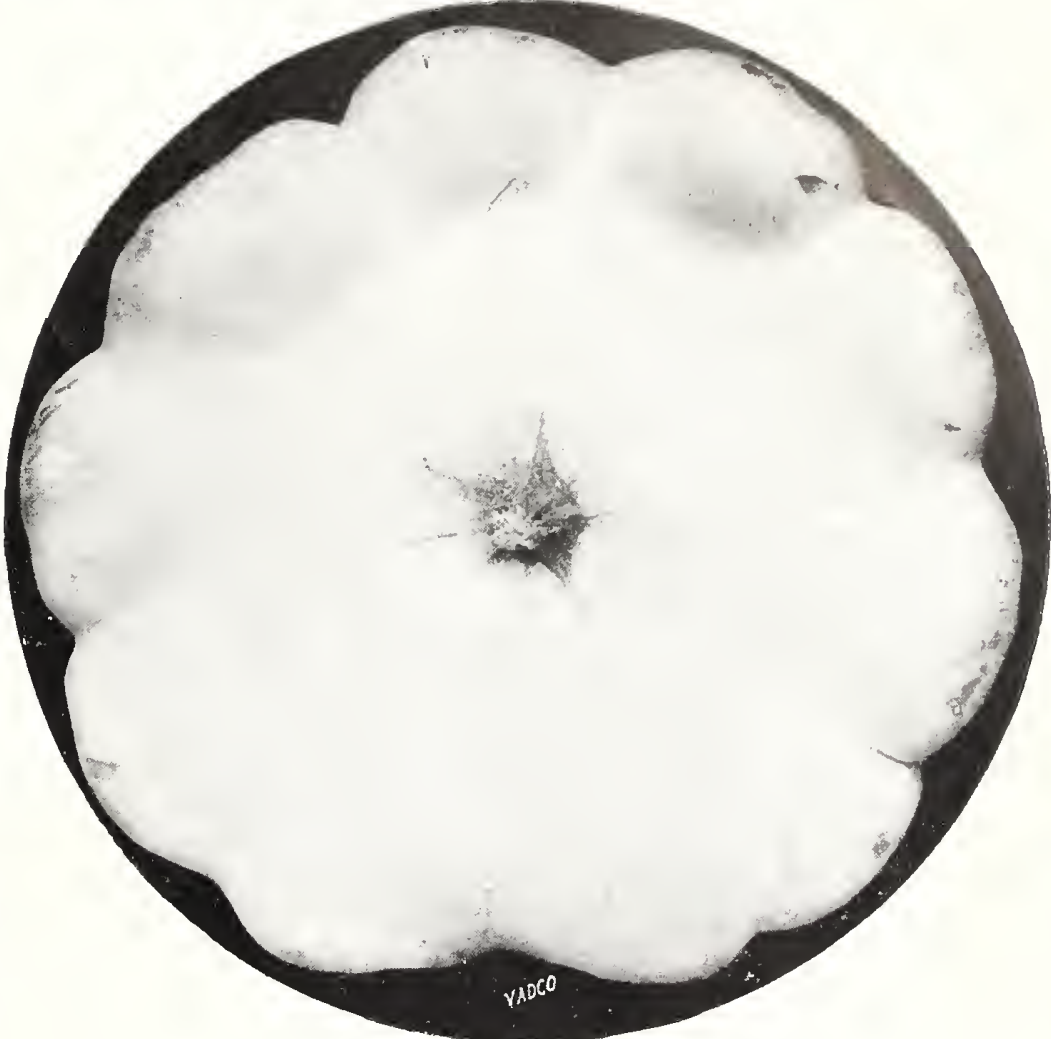

Vadco Mammoth White Bush Squash No. 983.

\section{NITRATE OF SODA}

THE BEST FERTILIZER FOR YOUR GARDEN

DIRECTIONS FOR USE.-Nitrate of Soda is not a substitute for other manures, but is the cbeapest and best form in which to apply Nitrogen to plants. Brake up the lumps before using and use as a top-dressing at the rate of 100 pounds per acre. Nitrate of Soda is especially beneficial for all varieties of vegetable and Flower plants but should not be applied until the young plants are well established. It should be used as a top-dressing for the following vetable plants: Beets, CabOnions For house plants, window boxes or home garden, apply as a liquid fertilizer using house plants, window boxes or home garden, apply as a liquid fer$25 \mathrm{c}$; $5 \mathrm{lbs}, 40 \mathrm{c}$; $10 \mathrm{lbs}, 75 \mathrm{c}$ postpaid. Not prepaid, $25 \mathrm{lbs}, \$ 1.00 ; 50$ lbs. $\$ 1.85$; 100 lbs. $\$ 3.50$.

\section{SPINACH SEED}

\section{SPINACH IS NATURE'S TONIC FOR THE BLOOD}

CULTURE.-Sow broadcast in rich ground from September to end of March e sown very thinly to leave room for large leaves, our marke gardeners sow Radishes and Beet the Beets transplanted by the time the Spinach needs more space.

No. 978-Virginia Savoy— The new Blight Resistant spinach. Thi Truck Experiment Station. It is the result of years of scientific work by the experiment station. It is a decided improvement over Bloomsdale Savoy as its grower and general Finders type ot growth. The low-growing wide spreading habit is springle for a winter spinach. Plants of this type attain a very large size in the $5 \mathrm{c} ; 0 z .10 \mathrm{c} ; 1 / 4 \mathrm{lb} .15 \mathrm{c}$; lb. $50 \mathrm{c}$, postpaid. Write for quantity prices.

No. 967-Vadco Bloomsdale Savoy Spinach— This sort is as the Norfolk Savoy Leaved. It is a very early variety and one of the best to plant in the fall for early spring use. The plant is of upright growth, with thick, used in Texas and Virginia. Pkt. 5c; oz. 10c; $3 / 4 \mathrm{lb} .15 \mathrm{c} ; 1 \mathrm{~b}$. 40c, postpaid. No. 968_Broad-Leaved Flanders_Has large leaves, 6 inche hardy, good winter variety. Pkt. $5 \mathrm{c} ; 0 \mathrm{z} .10 \mathrm{c} ; 1 / 4 \mathrm{lb} .15 \mathrm{c} ; 1 \mathrm{~b} .50 \mathrm{c}$, postpaid. No. 977_New Zealand-Nhis is a plant of a different genus ; entirely 4 to 5 feet high, thrives during the hot weather; can be cut nearly all summer. New cut off if you preserve the main shoot, and will continue in long bearing, surviving pretty heavy frost. May be sown early in April;
plants should be about 20 inches apart. Pkt. 10c; oz. 15c; 1/4 Ib. 35c; lb. \$1.2s, postpaid. 



No. 1027-The Van Antwerp Tomato-

No. 1008 - Cooper's Special or Self-Topper-

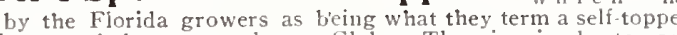

No. 1010-Van Antwerp's New Marglobe_- thustrated a ind Page 12 of thi
$\$ 6.00$, postpaid.

No. 1046-Louisiana Pink-i

fruits. It's a medium early variety
this tomato is the fincest

No. 1047-Louisiana Red-

No. 1031-Matchless—

No. 1017-Acme- It is a smooth, uniform; medium-sized, early, purple$90 \mathrm{c}$; lb. $\$ 3.00$, postpaid.

No. 1037-Ponderosa_Exceptionally large in size. It must have rich

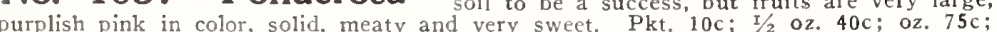
purplish pink in color, solid, meat
$t_{1} / 4 \mathrm{lb} \$ 2.50 ; 1 \mathrm{~b} . \$ 8.00$, postpaid.

No. 1019-Dwarf Champion-Matures in 95 days. Dwarf, stiff . Early and wonderfully prolific. Is perfectly round and smoo
Pkt. $100 ; 1 / 20 z .30 c ;$ oz. $45 c ; 1 / 4$ lb. $\$ 1.50 ; 1$ b. $\$ 6.00$, postpaid.

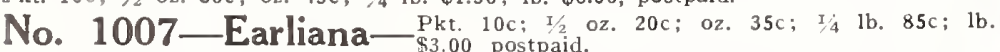
No. 1051-Golden Queen- Very handicome and the best large and sweet, with bright golden-yellow color. Pkt. 10c; $1 / 2$ oz. 20c; $02.35 \mathrm{c} ; 1 / 4 \mathrm{lb}$. 11.25, postpaid

No. 1067-Pear-Shaped Red-Matures in 95 days. Small fruit, Used in unbroken form for pickling. Color bright red. Pkt. 10c; 1 1 20z. 25c; oz. $45 \mathrm{c}$. No. 1059-Pear-Shaped Yellow- Matures in 95 days. Differing No. 1015-June Pink-Pkt. 10c; I/2 oz. 300; oz. 50c; I/4 lb. $\$ 1.50$;

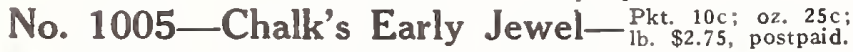

No. 1003-Bonny Best— Pkt. 10c; 1/202. 20c; oz. 35c; I/4 lb. \$1.25; No. 1077-Mansfield Tree Tomato- ${ }_{45 \mathrm{c} \text {. }}^{\mathrm{Pkt}}$

\section{(1) ONE OF OUR SPECIALTIES}

CULTURE.-Six or eight weeks before frost is over, sow $1 / 4$ inch deep in pt-beds, in shallow boxes in the house, and when they have made 4 leaves trans them do not allow the growth to be checked. Transplant 3 to 4 feet apart in a light.

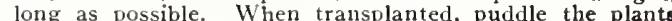
had by growing in pots, shifting to larger pots as they become filled with roots Earlness may be promoted by pinching off all the branches except the one most thrifty and tying this and the main stem to stakes. It all useless growth is removed more perfect fruits, and a more abundant crop. One ounce makes about 1,500

No. 1026-Vadco Gulf State Market—This new variety was and found the best slipping Tomato ever grown. It is earlier than any other good purplish variety. The vines are very strong and withstand bad weather; it is shaped, show but little depression about stem and are smooth and free from cracks. Color deep purplish.pink ripening well about the stem. The skin is firm and the flesh solid. This will prove to be the most productive of all shipping tomatoes. It is of the most desirable shape for packing. Gulf State Market is earlier than any
other purple tomato. While this new Tomato has been developed chiefly for the shipper, its many fine qualities make it desirable for the home and market gardener.

No. 1029-Vadco Globe Tomato- Distinct in shape, firm and ard variety for shipping purposes. It is an absolutely globe-shaped variety, ripens very early, color is a glossy red, tinted with purple. The vines are very vigorous and productive. Bears fruit in clusters of from three to seven fruits, so that it can varistance shippers and it caunot be recommende (Se illustra-

No. 1002-Vadco EI Primo-Unitorm in shape; early, of large size,

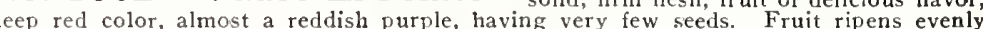

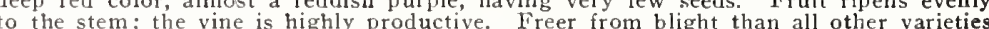
of Tomatoes. Pkt 10c; $1 / 2$ oz. 30c; oz. 50c; $1 / 4$ lb. $\$ 1.75 ;$ ib. $\$ 6.00$, postpaid.

No. 1025-Vadco Redfield Beauty— The fruits grow in clus. are as regular in shape and size as it is possible to produce. The color is its leading oz. 30 c; $1 / 2 \mathrm{lb}$. $\$ 1.00 ; \mathrm{lb}$. $\$ 3.50$, postpaid.

No. 1011 - John Baer- An early tomato that produces beautiful, large marvelous stem-setter, often making ten fruits in first cluster. It is solid and meaty and has just enough foliage. Every tomato will ripen evenly right up to the stem. lb. $\$ 3.00$, postpaid. No. 1016-Brimmer_ The Brimmer is practically all meat, has fewer and it is one of the very few tomatoes that is absolutely without a core. The flavor is mild, delicate and free from the acidity found in many other tomatoes. The well shaped, perfectly formed, solid, bright red fruits make a most tempting dish when Pkt irtit right up to frost. the fruits holding their size

No. 1045 -Improved Stone-Matures in 115 days. This variety is large size, bright scarlet color, very smooth. Ripens evenly to the stem without a

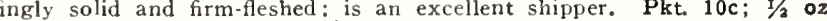
No. 1032 - Vadco Florida Special- Heavy cropper, larger size, let, ripens up to stem without green core. Pkt. $10 \mathrm{c} ; 02.35 \mathrm{c} ; \mathrm{r} / 4 \mathrm{lb} . \$ 1.25 ; \mathrm{lb}$ No. 1009 Early Detroit__ A valuable second early variety for home No. 1009-Early Detroit-use, market or shipping. Vines vigorous and productive. Fruits medium size, good form and have a
Pkt. 10c; $1 / 2$ oz. 25c; oz $40 \mathrm{c} ; 1 / 4$ lb. $\$ 1.50 ; 1 \mathrm{~b} . \$ 5.00$, postpaid.

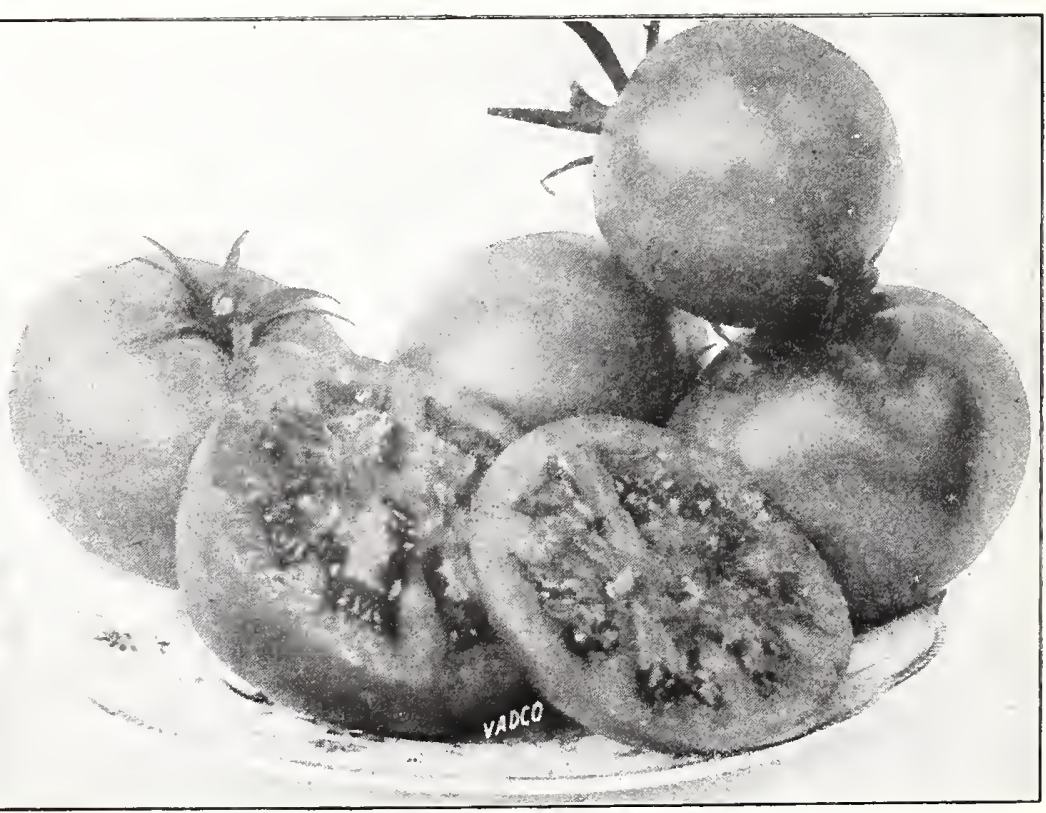

No. 1046-Louisiana Pink Tomatoes. A splendid wilt and rust-resistant variety. 


\section{TURNIPS}

\section{Plant \\ Plenty \\ Spring Turnips}

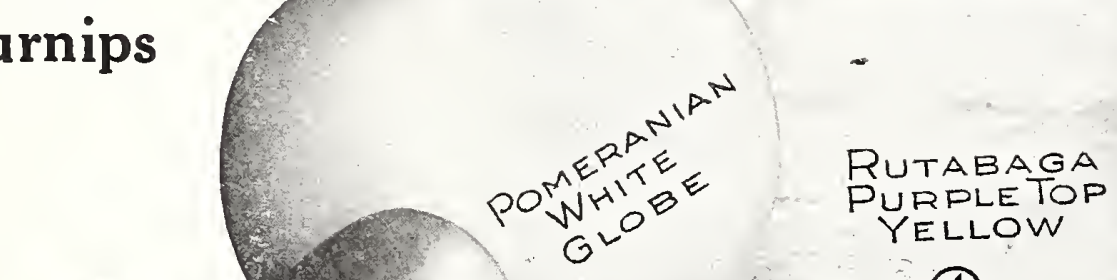

(4)

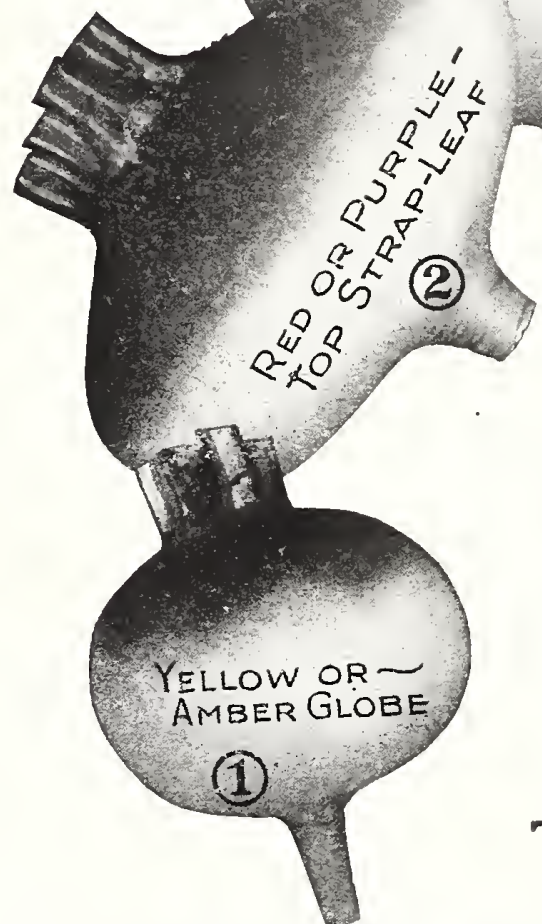

(3)
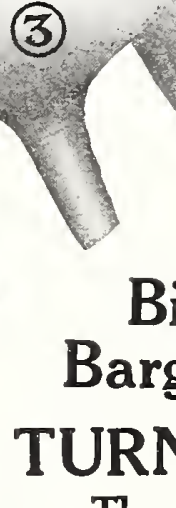

The 7 varieties as illustrated on this page
7 FULL OUNCES
7 VARIETIES

Order Collection No. 20

FOR THE SOUTH

Big

Bargain

Turnip

Offer

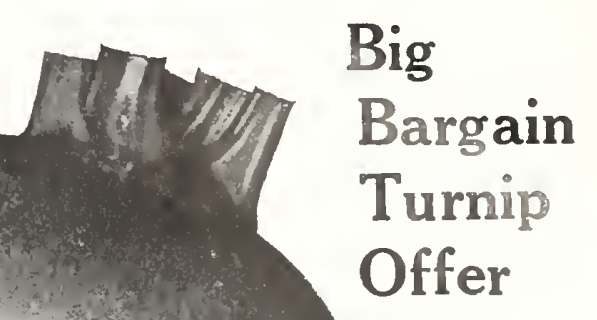

Turnips can be sown in the Southern States all the year round.

One ounce for 150 feet of drill; four pounds to acre. Cun chould be manured the previous seascn. Usually sown broadcast, but the Rutabaga and Large Yellow should be sown in drills 1 toot apart, so as to admit of being thinned out and worked. Spring sowings should be made as early as possible, so that the turnips may make their size before hot weather, otherwise they will become

No. 1101-Vadco-Jappois now one of the South's most pand globe in shane. The leaves grow upright and Price Vadco-Jappo: Pkt. 10c; oz. $15 \mathrm{c} ; 1 / 4$ ivo. 1 U99-Vadco Purple or Red Top Globe- Most popufor general planting. Medium early, globe shaped, handsome appearance and heavy cropper in all parts. Matures in 65 days. but with purple top. Fine variety lor $35 \mathrm{c} ; 1 \mathrm{~b}$. 60c; 5 lbs. $\$ 2.25$, postpaid. No. 1093 -Vadco Pomeranian White Globe- Matures in handsome, popular variety, useful both for table and stock, and well adapted for autumn and $60 \mathrm{c}: 5 \mathrm{lbs}$. $\$ 235$, postpaid.

No. 1097-Early Red, or Purple-Top Strap LeavedVery early, and a favorite market variety. Pkt. 5c; oz. 10c; $1 / 4 \mathrm{lb} .20 \mathrm{c} ; 1 / 2 \mathrm{lb} .35 \mathrm{c}$ No. 1087 -Early White Flat Dutch_- Matures in 60 days. A differing from the Early Red-Top only in color of skin, being pure white. The roots are of good size, sweet, mild

No. 1105-White Egg- Matured in 45 days. A splendid quick-grow fine-grained and solid flesh of sweet, mid flavor pkt. 5c; 0z. 10c; 1/4 lb. 20c No. 1095-Long White, or Cow Horn- Matures in 70 days heavy yielding qualities and fine-grained white flesh render it well wortly the attention of all garde
postpaid.
No. 1083-White Milan- Matures in 45 days. Extra early, yerg ivory-white color both inside and out; tender and delicately flavored. Pkt. 10c: oz. ${ }^{15 c ; 3 / 4} \mathrm{lb} .35 \mathrm{c} ;{ }^{1 / 2} \mathrm{lb},{ }^{65 \mathrm{c} ;} \mathrm{lb} . \$ 1.25 ; 5 \mathrm{lbs}$. $\$ 6.00$, postpaid. 15c; $1 / 4 \mathrm{lb} .35 \mathrm{c} ; \mathrm{T} / 2 \mathrm{lb} .65 \mathrm{c}$; lb. $\$ 1.25 ; 5$ lbs. $\$ 6.00$, postpaid. No. 1091 Yellow, or Amber Clobe-Matures in 65 days. A lowfleshed variety. One of the best for general crop. Flesh very fine and sweet, and keeps well until spring. Grows to a large size and is excellent for both stock No. 1107-Yellow Aberdeen- Matures in 70 days. A very hardy No. closely resembling a Rutabaga in shape, color and keeping qualities, but is of finer texture, and can be sown a month later. Flesh pale yellow and of fine texture. No. 1079-Mixed Turnips-Matures in from 45 to 90 days. Equal cluding White Miian. Pkt, 5c; oz, $10 \mathrm{c} ; \mathrm{r} / 4 \mathrm{lb}, 20 \mathrm{c} ; 1 / 2 \mathrm{lb}, 30 \mathrm{c}$; 1b. 50c, postpaid.

\section{SALAD VARIETIES}

No. 1103-Southern Seven Top, or Salad-This, the hardies! be left standing in the open ground during winter, as far north as Philadelphia. In the Southern States it yields in the spring abundant foliage for boiling with cured No. 1104 - Southern Prize, or Dixie- Hardy and needs no pro. rown f

Rutabagas or Swede Turnips No. 1112-American Purnle-Top Yellow- Matures in selected strain, which makes much larger and finer roots than the ordinary strains. 作 No. $1115-$ Sweet German, or Hanover- Matures in 60 days Thite-fleshed variety very solid and sweet. Pkt. 5c; 0z. 


\section{VEGETABLE PLANTS}

THESE PLANTS ARE ALL READY TO SET OUT IN YOUR GARDEN

If you are anxious for an early crop of vegetables you will get a quick start by setting out some of these plants first. You can also start seed at the same time in this way you will have a continuous supply of fresh vegetables for your table.

If you order seeds and plants at the same time, please remember the PLANTS will be shipped you in a separate package as we never ship seeds and plants in one shipment. Sometimes bad weather prevents us from shipping plants for a few days after we receive your order,

however, if you do not receive the plants you ordered within a reasonable length of time please notify us.
NOTE-No orders for plants from Florida will be accepted because of the Florida Plant Quarantine Law, causing plants to be delayed in transit and usually reaching destination in bad condition. No plants shipped C. O. D.

\section{TOMATO PLANTS}

We can supply the following varieties of TOMATO PLANTS any time from GLOBE

IMPROVED STONE

PONDEROSA

JUNE PINK

JOHN BEAR

EARLIANNA

DWARF CHAMPION

THE VAN ANTWERP

NEW MARGLOBE

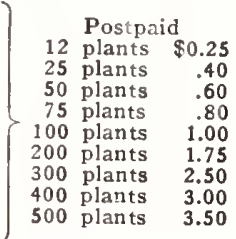

EGG PLANT PLANTS

From February 1st till August 1st.

BLACK BEAUTY
FLORIDA HIGH BUSH
NEW YORK PURPLE

PARSLEY PLANTS

THYME PLANT

CAULIFLOWER PLANTS

EARLY SNOWBALL

CELERY PLANTS
GOLDEN SELF-BLANCHING

$\left\{\begin{array}{l}\text { Prices } \\ \text { same as } \\ \text { Tomato }\end{array}\right.$

$\int \begin{gathered}\text { Postpaid } \\ 50 \mathrm{c}\end{gathered}$

Per Dozen

Postpaid

12 plants $\$ 0.25$

25 plants $\quad .50$

50 plants $\quad .75$
From February 1st till August 1st.

CHINESE GIANT

ROYAL KINC

RUBY KING
PIMENTO

LONG CAYENNE

TABASCO

We can supply the following varieties of vegetable plants any time from COLLARD PLANTS

CREOLE

LETTUCE PLANTS

BIG BOSTON

ICEBERG

MIGNONETTE

BEET PLANTS

MOBILE MARKET

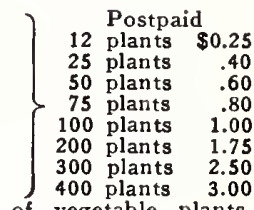

\section{ONION PLANTS}

From September till May 1st we are able to supply you with Genuine Onion Plants. They are much more satisfactory than sets and grow better shaped onions that keep much better than onions from sets. They are even more hardy than Frost-Proof Cabbage Plants, standing beavier frosts and even light freezes

You can have green onıons for pulling in your garden and you can have fine matured canions from these plants ten days to We can ahead or hions from seeds.

Yellow Bermuda and Red Creole. In 100 . 500 plants for $\$ 1.75, \$ 1,000$ plants for $\$ 3.00$, all postpaid.

\section{Hardy Frost-Proof Cabbage Plants READY FOR YOU FROM SEPTEMBER 1st TO JUNE 1st}

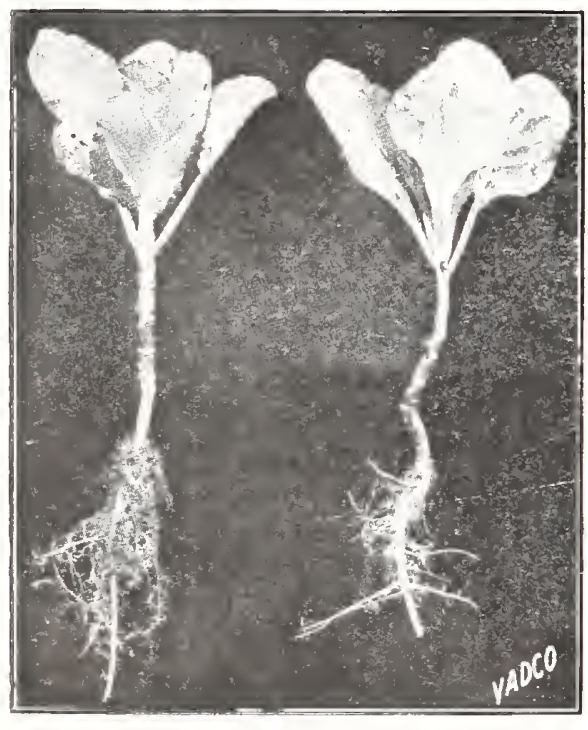

Our Frost-Proof Cabbage Plants Are Strong,
Sturdy, Well Grown Stock NO PLANTS SHIPPED C. O. D.

We offer the following varieties: Early Jersey Wakefield, Large Charleston Wakefield, Flat Dutch, All-Head Early, Early Summer, Succession and Drumhead. Remittances must accompany all orders. No plants shipped open account or C. O. D. Please do not ask us to break this very necessary rule.

NOTE-No plant orders accepted from Florida, because of restrictions of the Plant Quarantine Law causing delays in plants arriving at destination.

Orders will be shipped approximately three to five days after arrival, weather conditions permitting. If plants do not arrive as soon as you expect them, you may know that conditions beyond our control are responsible for the delay.

Plants usually withstand the cold winter, say at least six winters out of eight, in Texas, Louisiana, Mississippi and Alabama. In other territories, February and March are best months to plant. The word "frost-proof" does not mean "freeze-proof." However, you will be surprised at the amount of freezing weather the plants will stand. A temperature of 20 degrees above zero with sleet and snow seldom hurts them. Under favorable conditions, they stand it down to 13 above zero.

The plants when received will be somewhat wilted and have a hard, stunted appearance, which will be disappointing to persons who have never used these plants before. Regardless of appearance, they will produce splendid crop results. When we receive your order, we have to forward it to our growing station, and this requires several days. Plants cannot be pulled or shipped when beds are wet.

If the plants cannot be set out the same day they are received, take them from the crate immediately, dip the roots in water and heel out into the ground, spreading the bunches a little. In no case should they be left in the crate.

PRICES BY PARCEL POST, 50 Plants 35c-In lots of $100,200,300$ or 400 plants, at $50 \mathrm{c}$ per 100 plants; 500 plants for $\$ 1.75 ; 1,000$ or more at $\$ 3.00$ per 1,000 plants, postpaid

Orders are filed by the 100 , not 250 or 350 . These prices are for even quantities of one variety to a package; if you ordered 200 of one variety and 300 of another variety, you would remit at the 100 rate.

PRICES BY EXPRESS-Customer paying express charges. In lots of 1,000 to 4,000 plants at $\$ 2.00$ per 1,$000 ; 5,000$ or more at $\$ 1.75$ per 1,000 . Plants packed for express shipment, 1,000 or 2,000 plants of a variety to a package, weight about 25 pounds per 1,000 plants, packed for shipment.

\section{Flower Plants That Bloom}

We can supply the following very choice selection of FLOWERING PLANTS They are hardy, well-rooted stock, and the varieties offered are especially adapted to tbe South.

From February 15tb till June 1st:

$$
\begin{aligned}
& \text { SWEET ALYSSUM. White } \quad 12 \text { plants } \$ 0.50 \\
& \text { DOUBLE DAISY. (Bellis) Mixed) } 25 \text { plants } 1.00
\end{aligned}
$$

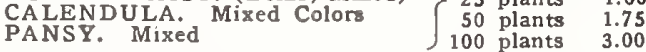

From March 1st till June 1st:

$$
\left.\begin{array}{l}
\text { ZINNIA. This is the new Dahlia } \\
\text { Flowered type. Very large double }
\end{array}\right\} \begin{aligned}
& \text { Postpaid } \\
& 25 \text { plants } \$ 0.75 \\
& 25 \text { plants } 1.25
\end{aligned}
$$$$
\text { blooms. }
$$

From March 1st till June 1st:

COSMOS, Giant Mixed
PINK. Mixed (Dianthus)
PHLOX. Mixed
MARIGOLD, African Tall
ZINNIA GIANT, Mixed
COLEUS.
SALVIA.
LARKSPUR
SHASTA DAISY
HOLLYHOCK
VERBENA. Mixed.

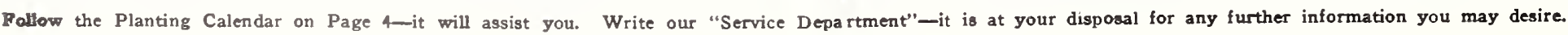




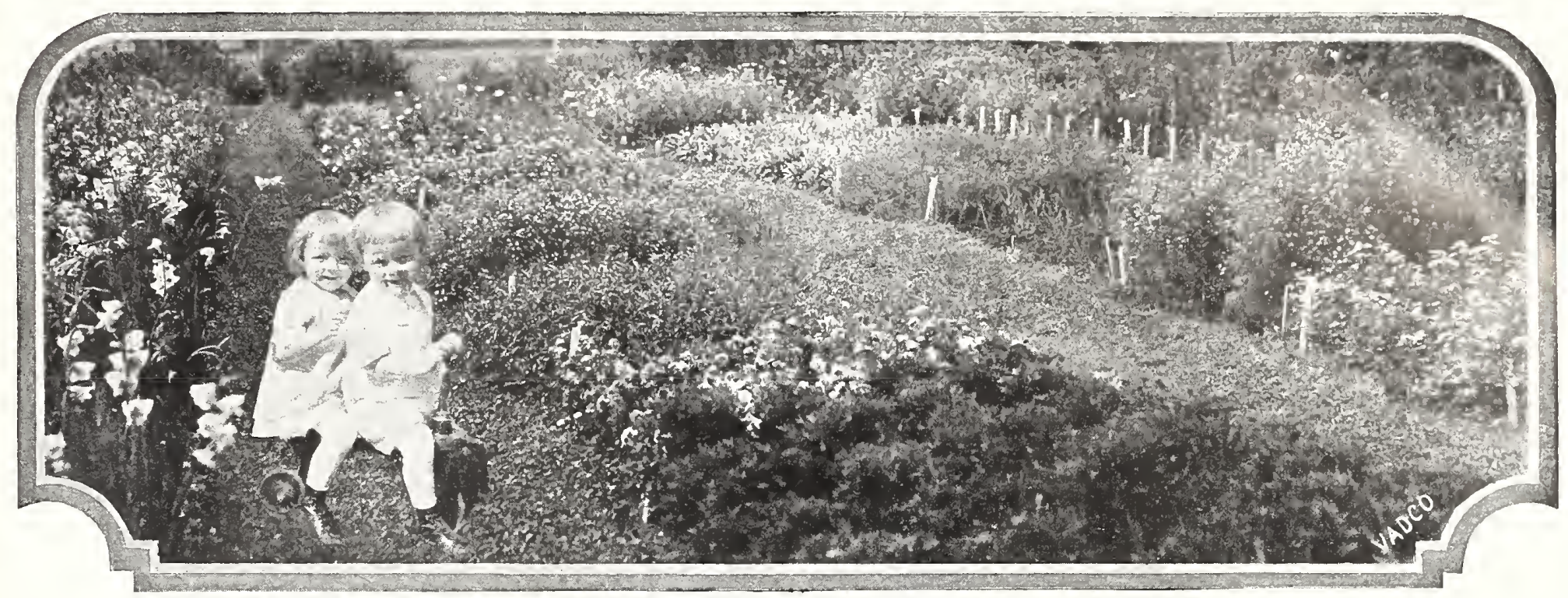

\section{FLOWERS ALL THE YEAR ROUND IN THE SOUTH VAN ANTWERP'S BARGAIN FLOWER SEED COLLECTIONS}

\section{"Sunny South" Collection of Flower Seeds No. 50}

Will Supply Cut Flowers All Summer

12 Full Size Packets

\section{$40 c$}

Postpaid

1 Packet Sweet Alyssum

1 Packet Giant Crego Asters

1 Packet Fine Mixed Candytuft

1 Packet Giant Mixed Cosmos

1 Packet Everblooming Hollyhocks

1 Packet Dwarf Mixed Nasturtium

1 Packet Choice Mixed Petunias

1 Packet Old-Time Garden Pinks

1 Packet Large Flowering Phlox

1 Packet Shirley Mixed Poppies

1 Packet Mixed Mammoth Sunflower

1 Packet Giant Flowering Double Zinnias

For $40 \mathrm{c}$ we will send you Van Antwerp's "Sunny South" Collection of Flower Seeds (12 varieties) postpaid. No changes will be allowed in this collection and no others will be sold at this reduced price. Order collection No. 50 .

\section{Children's Flower Garden Collection No. 52}

Let the Children Enjoy A Flower Garden

8 Large Packets

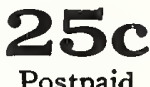

1 Packet Calendula Double Mixed

1 Packet Sweet Alyssum White

1 Packet Balsam Fine Mixed

1 Packet California Poppy Mixed

1 Packet Verbena Mammoth Mixed

1 Packet Cockscomb Plumed Mixed

1 Packet Nasturtium Dwarf Mixed

1 Packet Zinnias Double Mixed

For $25 \mathrm{c}$ we will send you the above Children's Flower Garden Collection postpaid. No changes will be allowed and no others will be sold at this special price. Order $\mathrm{Col}$ lection No. 52

\section{Collection of Annual Flowers That Climb No. 51}

Will Beautify the Front of Your Home

6 Large Packets

250

Postpaid

1 Packet Canary Bird Vine

1 Packet Cypress Vine, Mixed

1 Packet Hyacinth Bean

1 Packet Japanese Hop

1 Packet Imperial Morning Glories

1 Packet Mexican Coral Vine

For $25 \mathrm{c}$ we will send you the above flower collection postpaid. No changes will be allowed in this collection and no others will be sold at this reduced price. Order $\mathrm{Col}$ lection No. 51.

\section{READ THIS-IT WILL HELP YOU TO GROW FINE FLOWERS}

Most of the beautiful flowers that are seen around the grounds of the Northern homes are easier to grow in the Southern States.

You enjoy having the interior of your home beautiful, but the exterior appearance should recelve the same care and attention as it is of equal importance. Ther full of combined with fine health outloor exercise yOu can have beautiful flowers all year round VAN ANTWERP'S FLOWER SEEDS are famous in the South for over 40 years and are known as dependable frower seeds. The complete selection listed in this book are all especially grown for us by the most reliable Americe
European growers who have a lifelong experience at producing flower seeds.

We have selected varieties which we know are adapted for our Southern soil and climate, therefore you will be perfectly safe in making your own selection. You will find the quantity of seeds in our packets is very liberal and far exceeds the poorly filled commission seeds. Should there be some special flower that you would like to get seed of we will be glad to supply it as we always carry in stock a complete line, including many not listed in this book.

Some varieties of flowers which are biennials in Europe or the North, flower here the first season: if they do not, they generally do not flower at all, as the are usually destroyed by the continued long heat of our summers. Some grow quicker and attain greater perfection than in a more northern latitude. The secre of success in growing flowers is to pulverize the soil fine and light enough so that it will not bake after a rain; make rich with well-rotted manure; commercial fertilizer or bone meal will answer the same purpose, as fowers thrive better in ver rich earth. Should the soil be heavy mix with sand to make tight, so hat it may
Pretty Effects in Flower Beds-Care should be taken in transplanting or sowing if you wish to have a pretty and effective flower garden. In bedding the flowers, center of a four-sided bed, or against the fence, if your bed is in this position. ANNUALS are those flowers that attain their full growth, bloom and die the first year. Among these are Asters, Balsam, Cosmos, Zinnias, Mignonettes, Sweet Nosturtiums, Morning Glories and other

BIENNIALS produced from seed generally flower the first and second year of the plant being two season

PERENNIALS usually do not flower the first year, unless started early in the season. Perennials live and blossom year after year. These sorts constitute the HOW YOU WILL KNOW

When ordering watch for the following abbreviations which will tell you the class the flower you are ordering belongs to. They are marked as follows: "A" OUR OWN MIXTURES

All flower seeds offered in this book marked VADCO FARMS MIXTURES are real choice mixtures of all the separate colors of the one variety such as VADCO FARMS ASTER MIXED. These mixtures are blended by our own seed experts with a view to giving our customers a variety of colors and not just one or two
colors of a poor shade so often supplied and sold under the name of mixed varieties. Customers when ordering should bear this in mind and if you desire a complete Celection 


\section{ASTERS. A.}

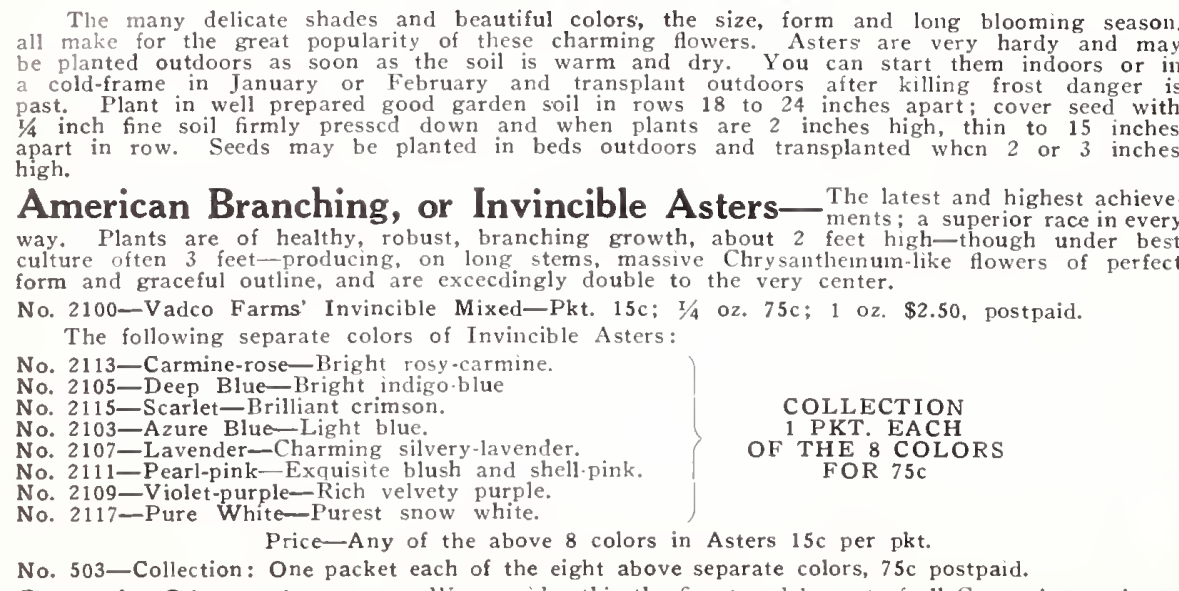

Crego's Giant Asters- We consider this the finest and largest of all Crego Asters, bear-

No. $2120-$ Prize Mixture. Pkt. 10c; 3 pkts. 25 c; 1/4 oz. 50c; 1 oz. $\$ 1.50$

Ostrich Feather- The flowers of this class resemble the Japanese Chrysanthemum with mence size: 27 ' feet. (See illustration.)
No. 213u-Finest Mixed. Pkt. 10c; 1/4 oz. 50c; 1 oz. \$1.50.

Semple's Late-Flowering Asters- Superior late-flowering Branching Asters. The long stems. They begin blooming about the first of September. 18 inches to 2 feet high.

No. 2140-Mixed Colors-Pkt. 10c; $1 / 4$ oz. 40c; 1 oz. \$1.50.

No. $2150-$ Single China Aster Mixed-Pkt. $10 \mathrm{c} ; \mathrm{T} / 4$ oz. $35 \mathrm{c}$; oz. $\$ 1.25$

\section{Alyssum. A.}

Makes a Splendid Border

This inost popular hardy annual needs little introduction. Used extensively as a border for
the flower-garden, but equally valuable as a cut-flower, owing to its delighttrul fragrance.

No. 2019- "Carpet of Snow" or Little Gem. A.- Pure white, very scented; the best white flowering border plant; 4 inches tall. Pkt. 10c; oz. 75 c. No. 2017-Maritimum (Sweet Alyssum) - $\begin{gathered}\text { Trailing habit. } \\ 20 \mathrm{c} ; \text { oz. } 35 \mathrm{c} \text {. }\end{gathered}$

No. 2021_Lilac Queen- Lilac-colored fowers. Contrasts prettily with the white No. 2023-Alyssum Saxtile Compacta, Yellow. P._- A beautiful dwart for spring beds or edging a flower border. The flowers are produced in large clusters and are AGERATUM. See page 35.

\section{Antirrhinum or Snapdragon. P.}

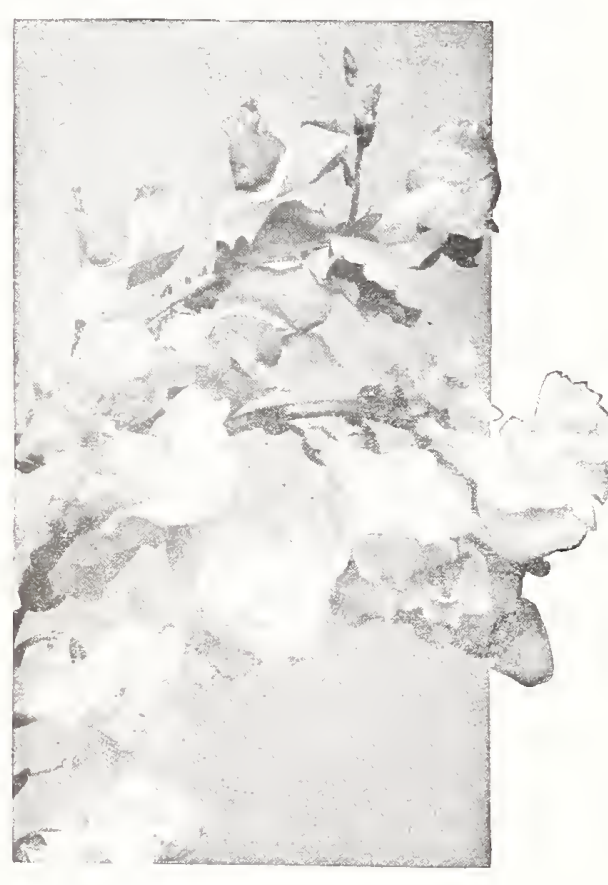

Snapdragon Tall Mixed No. 2040
You will be delighted with this bedding and border plant with its long blooming
season. The long, showy spikes of tubular season. The long, showy spikes of tubular
flowers are very beautiful and showy. They make splendid cut flowers, and they last a long time after being cut. They grow 18 to 24 inches high and though a perennial, will bloom the first year if sown very early in boxes in the house o ground is warm and dry. outdoors whe

No. 2040 - Vadco Farms' Mixture Tall VarietiesNo. 2050-Semi-Dwarf All

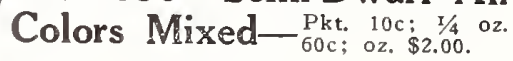

The following separate colors: Pkt

each, 10c; 3 pkts. 25c.
No. 2053-Blood Red.

No. 2055-Deep Scarlet.

No. 2057-Light Pink.

No. 2054-Dark Maroon.

No. 2059-Orange-Scarlet.

No. 2061-White.

No. 2063-Yellow.

No. 2056-Pink White Throat.

No. 500-Collection-

1 packet each above 8 colors of Antirrhi-

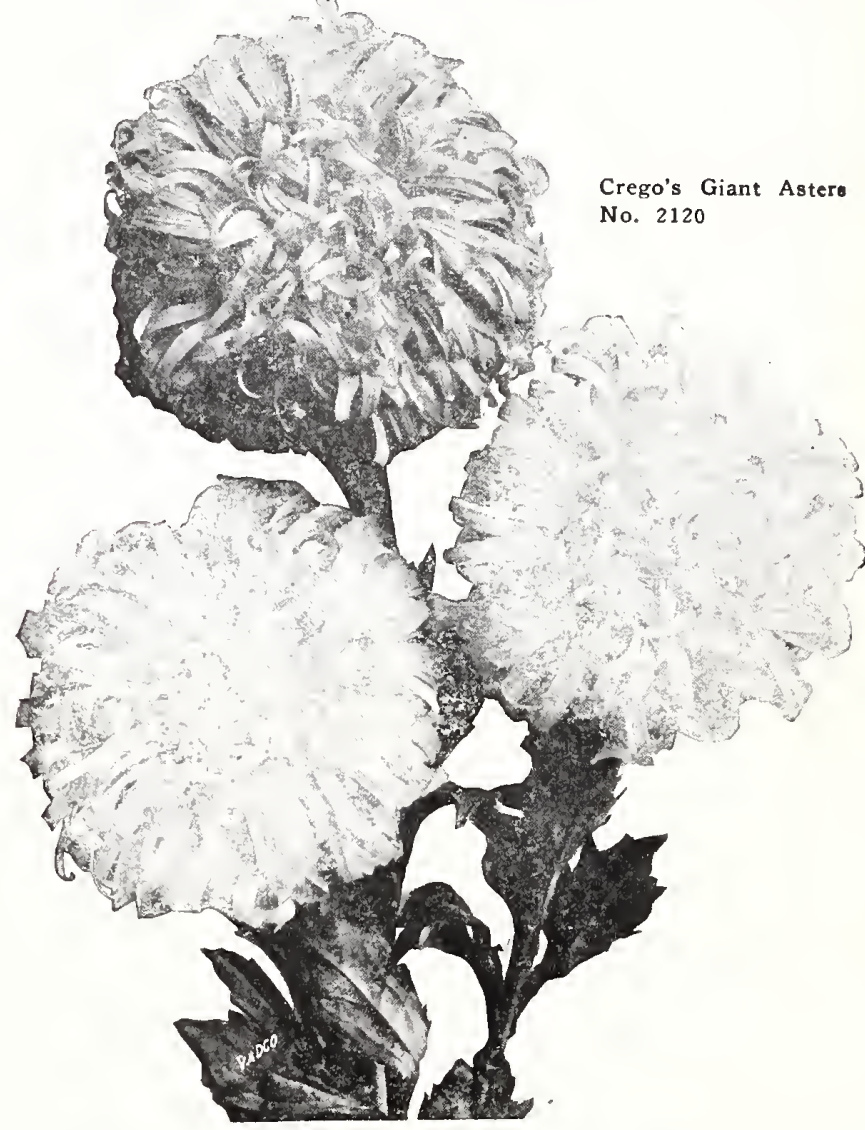

\section{A Few Choice Annual and Perennial Flowers}

No. 1999-Achillea Ptarmica, Double, "The Pearl." P.— - Theezewort or Double White Yarrow, ONe of small, double, white flowers during the entire season. Fine for cutting and

No. 2000-Acroclinium. A. - - very producing rose-colored daisy-like flowers in August and Sreptember. These are the "Immorteless", so desirable for wreaths and winter bouquets. One No. 2005 - Adonis (Floss Adonis). A. 12 inches; flowers crimson and small. Seed should be sown in the
autumn. Pkt. 10c. No. 2007-New African Daisy, Golden West The Golden West is a beautiful new variety with bright orange
flowers that have dark centers. Pkt. $10 \mathrm{cos} ; 3$ pkts. $25 \mathrm{c} ; \mathrm{y} / 2$ or. $75 \mathrm{sc}$; No. 2013 - Agrostemma coronaria atrosanguinea- Rose Campion. Crimson. 2 ft. July. Sept. Long stems; No. 2031-Ampelopsis (Boston, or Japanese

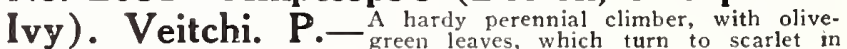
the autumn. The best and most popular climber for covering brick No. 2029-Amaranthus. Caudatus (Love Lies Bleeding). A.- C c cight yellowisho, green foliage; long, drooping, No. 2035-A Antigonon. A. (Mexican Coral Vine) - Lovely and popular climber with long racemes of beautance. Pkt. $10 \mathrm{c} ; 3$ pkts. $25 \mathrm{cc}$.
No. 2032-Anemone coronaria, St. Brigid(Poppy-flowered Anemone.) Mixed colors, 10 in. May June. The No. 2083-Artotis Grandis (The African
certrat Lilac Daisy). A.- Growes in large branching bushes, 2 feet

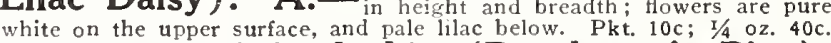
No. 2085-Aristolochia (Dutchman's Pipe). A.- A splendid climber of tropical origin, vell adapted for porches. are dark green and plants make rapid growth. Flowers three inches 


\section{BALSAM}

The Old-Fashioned Flower Touch-Me-Not or Lady Slipper. A.

The old and familiar Touch-Me-Not or Lady-Slipper improved an til those familiar with the old forms would hardly recognize the large waxy flowers with their elegant shades of color and variega. and well repay one for the little trouble. (See illustration.

No. 2170-Vadco's Farms' Tall Double Mixed. Pkt. 10c; 1/4 oz. 40c; oz. $\$ 1.25$.

No. 2180-Rose Flowered Double Mixed. Pkt. 10c; 1/4 oz. 40c;

The following separate colors in Double Balsams. $10 \mathrm{c}$ per

No. 2181 -White.

No. 2185 二

No. 2183-Rose.

No. 505-Collection.

for 35

No. 2165-Balsam Apple_ 10 feet. A very orgrowing climber. While it has a flower, it is grown mostly for
the effect of the fruit which follows. This is yellow. looks not unlike an apple-hence its name. When ripe it opens and shows

No. 2167-Balsam Pear- $\mathrm{fr}_{\mathrm{r} u \text { it }}^{\text {Like }}$ is pear-shaped. Pkt. $10 \mathrm{c}$.

No. 2251-Canary-Bird Vine. A.- - $\begin{gathered}\text { Aul, rapid } \\ \text { beati- }\end{gathered}$ growing annual climber, the charming little canary-yellow blossoms bearing a fancied resemblance to a bird with its wings half expanded. The sprays of flowers are very artistic and keep when cut in good condition for a week. The plant has a fine, luxuriant, rambling

Cannas From Seed. P._- These are usually planted plants, but they can be successfully grown from seed if planted rarly. The seed should be pierced in one spot with a file and
soaked in lukewarm water for 24 hours before sowing. A splendid lot of plants may be produced at a much reduced cost. splendid lot of plants may, be produced at a much
No. 2270-Giant Flowered, Mixed. Pkt. 10c. oz. 50c.

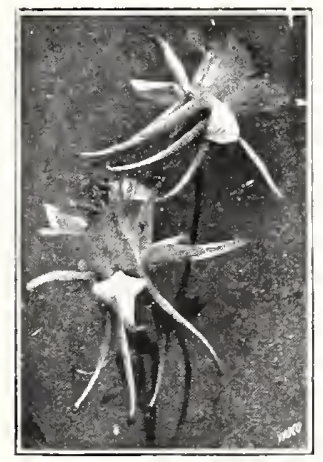

\section{Aquilegia. P. Columbine}

Hardy garden perennials. Very effective when grown in beds or the herbaceous border. Height $11 / 3$ (See illustration.) Spurred Hybrids, Mixed-Beautiful longering, Longdouble flowers, formed of several rows of cornucopialike petals and in various shades of yellow, lavender, blue, indigo and white. Pkt. 25c.

No. 2080-Single, Large-Flowering, Mixed Colors-Pkt. 10 ; $1 / 4$ oz. $40 c ; 1$ oz. $\$ 1.25$.

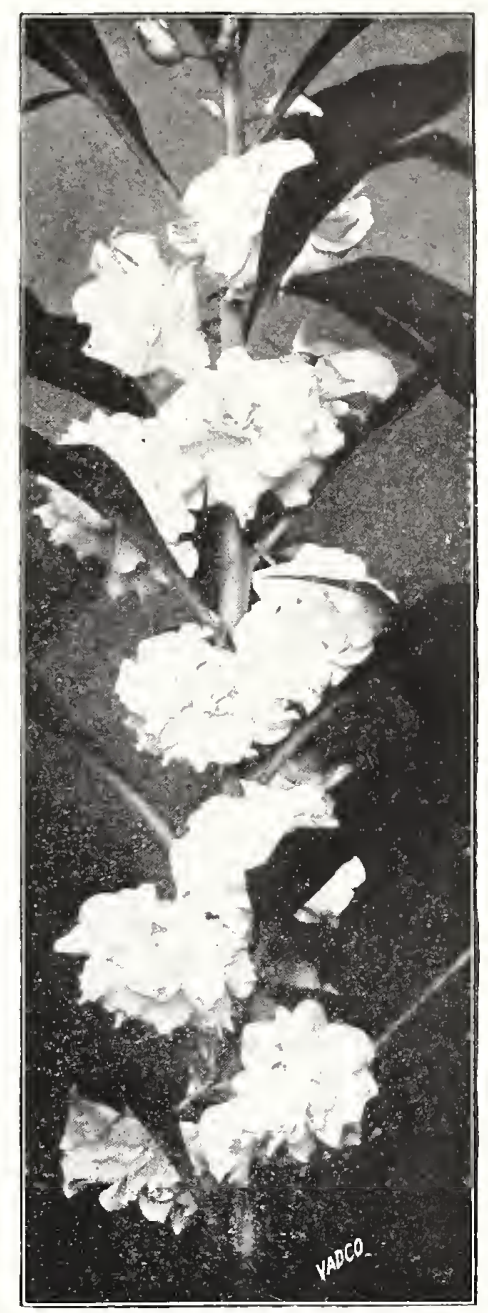

BELLIS

English Daisy. P. 6 to 8 Inches

A low growing, spring flowering plant Loves a shady place ceding years if left undisturbed. A For best results, new plants should be raised from till August.

No. 2210_-Vadco Farms' Double Mixed - Pkt. 10c; 1/4 oz. $\$ 1.00$

No. 2213 - Snowball_ Double pure white. Pk

No. 2215-Longfellow - ${ }_{10 \text { c. }}^{\text {Double dark pink. Pkt. }}$

No. 2193-Bartonia Aurea_(Golden Bartonia). Neet tall is a native of California. Bright yellow single flowers, 2 feet tall; is a native of California. Bright yellow single flowers, ince it does not transplant easily. Pkt. 10c; $1 / 4 \mathrm{oz}, 35 \mathrm{c}$.

No. 2163-Balloon Vine-A nual climber; succeeds best in light soil and warm situation: (ike miniature balloons and great interest to children. Pkt. 10c; 3 Pkts. 25c.

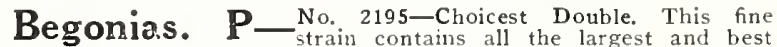

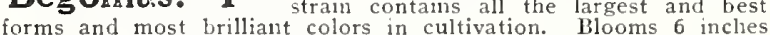
across. Pkt. 50c: 2 pkts. 90c

No. 2200-Mixed Single, including Fringed Varieties. The blooms are borne on long stout stems, which raise them well above the foliage. For size and quality of the flowers, combined 2 pkts. $40 \mathrm{c}$.

No. 2223-Brachycome- (Swan River Daisy). Agrowing annuals; covered during the greater part of the summer with a profusion of pretty blue or white flowers, suitable for
edgings, small beds or pot culture; 9 inches. Pkt. 10c; $1 / 402.35 \mathrm{c}$.

Calliopsis. P_- One of the showiest and most easily

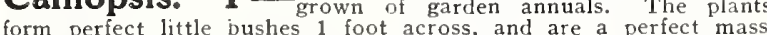
form perfect little bushes 1 foot across, and are a perrect mass average nearly 2 inches across. No. 2247-Drummondi (Golden Wave). Yellow, maroon center
Pkt. 10c; $1 / 4$ oz. 40 c.

Vadco Tall Double Balsam. No. 2170

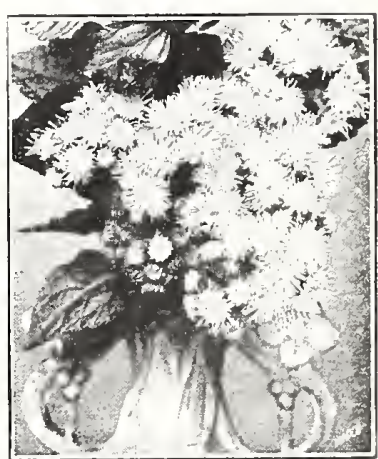

Ageratum No, 201

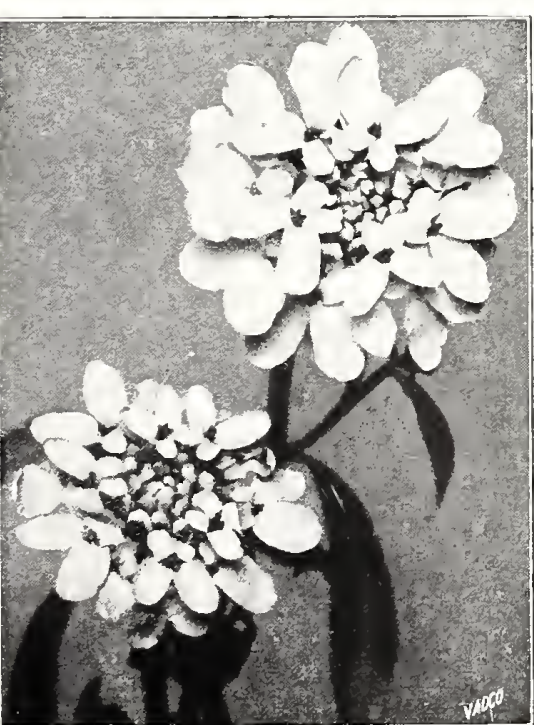

Vadco Fancy Mixed Candytuft. No. 2260.

\section{CANDYTUFT, A.}

Should $\mathrm{Be}$ in Every Garden

A well-known garden favorite for beds, borders and edging. Sow seed as soon as soil can be worked in spring. Whe for early summer beds masses and cut-flowers. Grows 12 hardy. (See illustration.)

No. $2260-\mathrm{V}$ a

No, 2261-Giant Hyacinth-Flowered or Imported Empress. As the result of extra care and painstaking selection this is now the finest of all the white varieties, being a complete mass of pure white flowers

No. 2263-Giant Crimson. Pkt. 10c; $1 / 4$ oz, 40c.

No. 2265-Giant Rosy Lavender. Pkt. 10c; $1 / 4$ oz. $40 \mathrm{c}$. postpaid.

HARDY CANDYTUFT, $P$.

Handsome, compact-growing, hardy perennial plants, ad mirably adapted for permanent front rows of borders or

No. 2267-Gibraltica— red and large-growing, No. 2 feet. Pkt. 10 c.

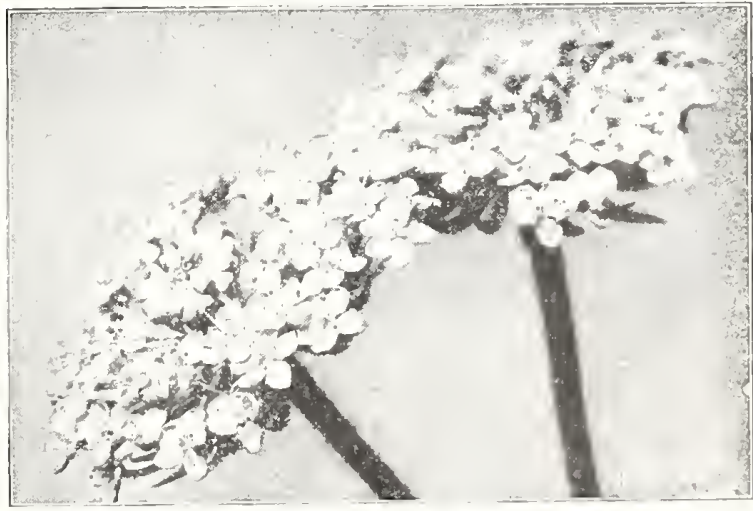

Blue Lace Flower (Queen Anne's Blue Lace). No. 2219.

No. 2219-Blue Lace Flower-

cannot do without in your garden. Beautiful, like flowers, similar to wild carrot, but of a lovely, delicat hotbed in March and outdoors in May and again in June, and you can cut flowers until 


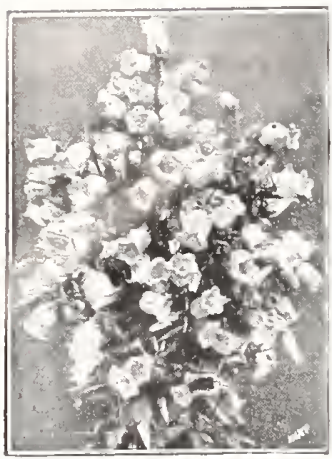

Canterbury Bells No. 2280

\section{Canterbury Bells}

A hardy biennial, blooming the second year from seed, or the first year, if sown early. Easily grown and preferring rich, moist soil. Grows about 3 blue, white, purple and red flowers. No. 2280-Vadco's Farms' Single Mixed-Pkt. 10c 4 0z. $50 \mathrm{C}$

No. 2290-Double Mixed-Pkt. 10c; 1/4 oz. $50 \mathrm{c}$ No, 2300-Cup and Saucer Type-In this variety Pkt. 10c; $1 / 8$ oz. $75 \mathrm{c}$.

\section{CHRYSANTHEMUMS}

\section{Annual Variekies}

The varieties listed here are lardy free flowering annual summer Chrysanthe mums and should not be confused with those grown by florists. They grow from 2 to 3 feet high and produce graceful, brilliant flowers. Fine for beds and borders. No. 2360-Coronarium Double Mixed-Pkt. $10 \mathrm{c}$

No. 2370-Mixed Single Annual Varieties-Pkt. 10c; 3 pkts. 25c.

No. 2373-Hardy Oriental Chrysanthemums. P.Original Japanese bardy Chysanthemum comes to us direct from Japan and is save from a magnificent collection of over one hundred varieties, and cannot fail to pro duce satisfactory results. Seeds sown in spring will produce flowering plants by fall. Pkt. 25c; 2 pkts. $40 \mathrm{c}$.

\section{CORNFLOWERS}

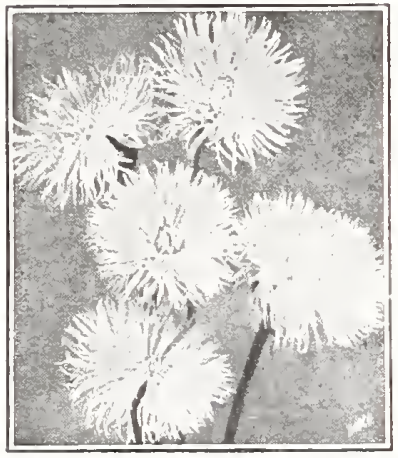

Sweet Sultan No. 2400

\section{Centaurea Cyanus}

Well known annual growing about 2 feet high. The flowers are borne on long slender in beds.

Bluet and sometimes known as Bachelor's Buttons, Blue Bottle, Ragged Sailor, Bluet and sometimes as Ragged Robin, but which name belongs to one of the Lychnis and frequently results in confusion. They are well known to every themselves, coming up year after year A bunch gardens. They usually re-seed yellow Calliopsis, Marigolds, Calendulas or California Poppies, make a very rich combination. No. 2390-Vadco Farms' Double Mixed-Splendid mixture of all existing colors. Noz, 25c; Oz. $40 \mathrm{c}$

(1/4 oz $35 \mathrm{c}$.

White Leaved Centaureas_- Dusty Millers-Fine for bedding, also extensively used for margins. As an edging to a bed of dark-leaved pots or Scarlet Sage these are particularly effective. Sow the seed early indoors, and transplant later. No. 2405-Gymnocarpa-Fine cut silvery foliage; 11/2 feet. Pkt. 10c; 3 pkts. 25c.

\section{SWEET SULTANS}

\section{Centaurea Imperialis}

The finest of all Sweet Sultans for cut flower purposes; gigantic, beautiful, sweet ecented flowers borne on long stems. They are well adapted for cutting and remain fresh long after being cut. Height, 2 to 3 feet. See illustration.

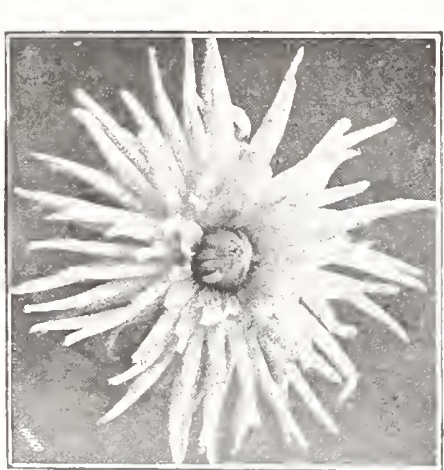

Dahlia No. 2510

\section{DAHLIAS}

These grand autumn flowers can be as easily raised from seed, and bloom the first season, as when grown from the roots. They should be sown early in the house to secure early blooming. When not convenient to plant under glass, sow as soon as it is warm enough.

No. 2510-Vadco Finest Double MixedSeeds saved from choicest double flowers, including shades of red, pink, dark maroon, yellow, white, etc. Pkt. 10c; 3 pkts. $25 \mathrm{c}$ No. 2520-Finest Single Mixed-Will pro duce brilliant flowers running through a wide range of striking colors. Pkt. 10c; 3 pkts. $25 \mathrm{c}$

\section{CALENDULAS \\ Make Wonderful Cut Flowers}

One of the best and showiest free-flowering hardy annuals, growing well is any garden soil. They make tne cut-flowers; attractive beds' and borders and bloom profusely In grandmother's garden, they were familiarly known by the old fashioned name
of Pot Marigold.

Although the old fashioned Calendulas were highly prized for their ease of cul. coure and extremely free blooming qualities, the flowers were small and
could in way be compared to the wonderful double varieties of today.

The Calendula thrives almost anywhere, it is equally as much at home in poor sandy soil as in beavy soil. For the gardener with limited garden space, there is no into late fall, thereby producing an uninterrupted supply of flowers for table decora. tion. (See illustration.)

No. 2241-Lemon King-Large very double lemon flowers. Pkt No. 2243-Prince of Orange-A fine deep orange; double, Pst. No. 2240-Vadco Farms' Double Mixed— oz. $35 \mathrm{c}$; 0z. $60 \mathrm{c}$.

No. 2087-Artemesia or "Summer Fir." A.- It forms bushes 3 to 5 feet high. As a solitary plant it looks like a nicely developed Christ bushes 3 to 5 feet high. As a
mas tree. Pkt. $15 \mathrm{c} ; 2$ pkts. $25 \mathrm{c}$.

Asparagus. P._- Seeds start slowly and should be soaked in good warm climber where there is little frost.

No. 2089-Plumosus Nanus— Pkt. 20c; 100 seds, \$1.00.

No. 2091-Sprengeri (Emerald Feather)—- - $_{\text {seds s, soc. }}^{200 ;} 100$ 


\section{COCKSCOMBS (Celosia)}

The dwarf Cockscombs are showy in the border. The feathered or plumed varieties are especially attractive in large beds, and are useful for cutting. The flowers retain their color even when dry, and can be used in winter bouquets. Seed shouid be sown in March for early flowers; for succession sow outdoors in seed-bed in May and transplant when large enough to permanent
space of 8 inches between plants for Cockscomb and 18 inches for Feathered varicties.

No. 2340-Celosia Plumosa (Feathered Cockscomb). A. - $\underset{d}{\text { A e c cor } \text { ra. }}$ tive plant for the garden. The feathery plumes are produced on long stems and are excellent for Vadco Farms' Plumed Mixed-An improved strain with various colors, ranging fron

No. 2350-Crested Cockscomb. A. - Very desirable annuals of easy culture, promake excellent border plants, and are also attractive for pots; 1 to $11 / 2$ feet. Crested Mixed $-D$ war

No. 2353-Chinese Woolfower (Celosia) - A new variety of feathered Celosia like balls of wool. They grow 3 feet high and are very effective in masses, in the center of beds. and in among shrubbery for color effect. The plants branch freely, each branch terminating with a fower-head. It continues in flower from early summer until frost, and is very effective for gard
either massed or grown as individuals. (See illustration.) Pkt. 10c; 3 pkts. $25 \mathrm{c} ; 1 / 4 \mathrm{oz}$. 50c.

\section{VAN ANTWERP'S COSMOS}

The Glory of the Autumn Garden. A.

Beautiful summer and autumn blooming plants. They produce thousands of artistic flowers in pure white, pink and crimson shades, furnishing an abundance of cut blooms for autumn decoration when other flowers are scarce. Should be sown in spring in the open ground, when danger of thast is past, or the seed may be started under cover and afterwards transplanted. Plant not less should be pinched out to induce a bushy growth. They prefer a rather light, not too rich soil, No. 2450-Vadco Farms' Early Large Flowering Mixed. Pkt. 10c; 3 pkts. 25c; 1/2 oz. 40c; oz. 75c.

No. 2480_Crested Cosmos_Crested or Anemone-Flowered Cosmos are very beau. are double crested, having double centers, with a row of guard petals around the base, which make
them very effective. The colors are pink, crimson and white, offered in mixture. Pkt. 15c; 2 pkts. 25c. No. 2485-New Large-Flowering Double Cosmos. A.— Full double largest size, like miniature peonies, on long stems and of great substance. In bloom at the same time
as the Lady Lenox type, and beautiful in vases. (See illustration.) Pkt. 25c;2 pkts. 40c.

No. 2457-Yellow Cosmos "Klondyke"—- Golden yellow flowers borne on long $31 / 2$ inches across. Pkt. $10 \mathrm{c} ; 3$ pkts. 25c; $1 / 2$ oz. 35c

\section{Late Mammoth Cosmos}

\begin{abstract}
No. 2459-Crimson. Pkt. 10c; 1/4 oz. 50c.
No. 2461-Rose. Plat. 10c; 1/4 oz. 50c.

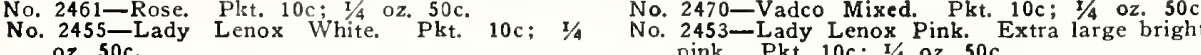

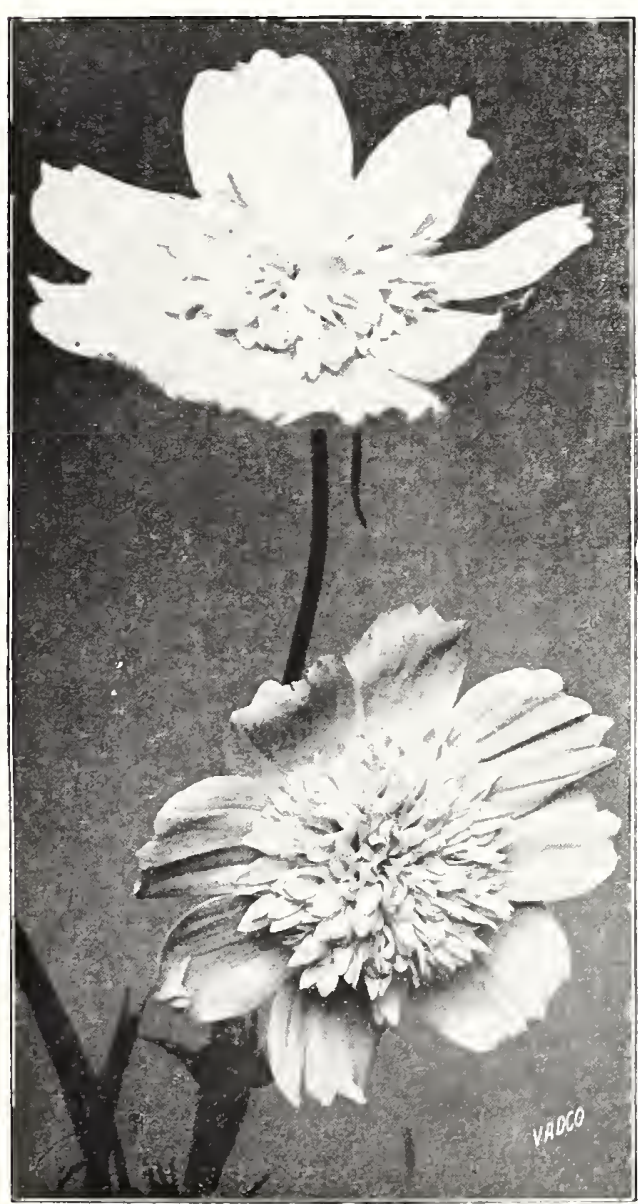

Our New Iarge Flowering Double Cosmos No, 2485
No. 2310-Giant Marguerite Carna. tion. P. - An extra vigorous race. Especially adapted trim in habit, perpetual, and flower abundantly in five months from sowing the seed. Marguerite Carnations are
highly fragrant, and have beautiful double flowers. Mixed. No. 2320 -Chabaud's Everblooming Carnations. P. - Flowering continuously after six thick-set and bushy; stalks stiff and upright, bearing immense double blossoms of perfect regularity, some with fringed edges, some with smooth, some with rich solid colors, others tinted and blended, and others with featherings and picotee markings, and all perfuming the air with 2 pkts. $40 \mathrm{c}$.

No. 2420-Coleus (Flame Nettle)There are no finer decorative foliage plants for the South than Coleus; easily raised from seed sown in boxes in Vadco Farms' Hybrid Prize Mixed. Pkt. 15c; 2 pkts. No. 2443--C o r e o p s is Lanceolata Grandiflora. P.- No Alower is longer in bloom Coreopsis. It is a most excellent cut flower, lasting perennial, 2 feet. Pkt. ioc; 3 pkts. 25c: $1 / 2$ oz. 50c.

No. 2490-Cyclamen Persicum Giganteum Mixed Most beautiful winter an santeum, Meding flowering plants for the striking beauty but the foliage is also highly ornamental. Pkt. 25c; 2 pkts. 40c.

Delphinium (Hardy Perennial Larkspur)— These are taller than the annual sorts and tion even at a distance. The foliage is attractive and the plants strong and neat in habit. We advise sowing in a No. 2530-Vadco Farms' Finest Single Mixed-Pkt. $10 \mathrm{c} ; 1 / 4$ oz. $50 \mathrm{c} ; 1$ oz. $\$ 1.50$. No. 2540 - Gold Medal Hybrids This is one of our most important specialties, and is
unquestionably the finest strain of mixed hybrids ever offered. The plants are of strong, vigorous habit, with running in the lighter shades of blue. Pkt. 25c;

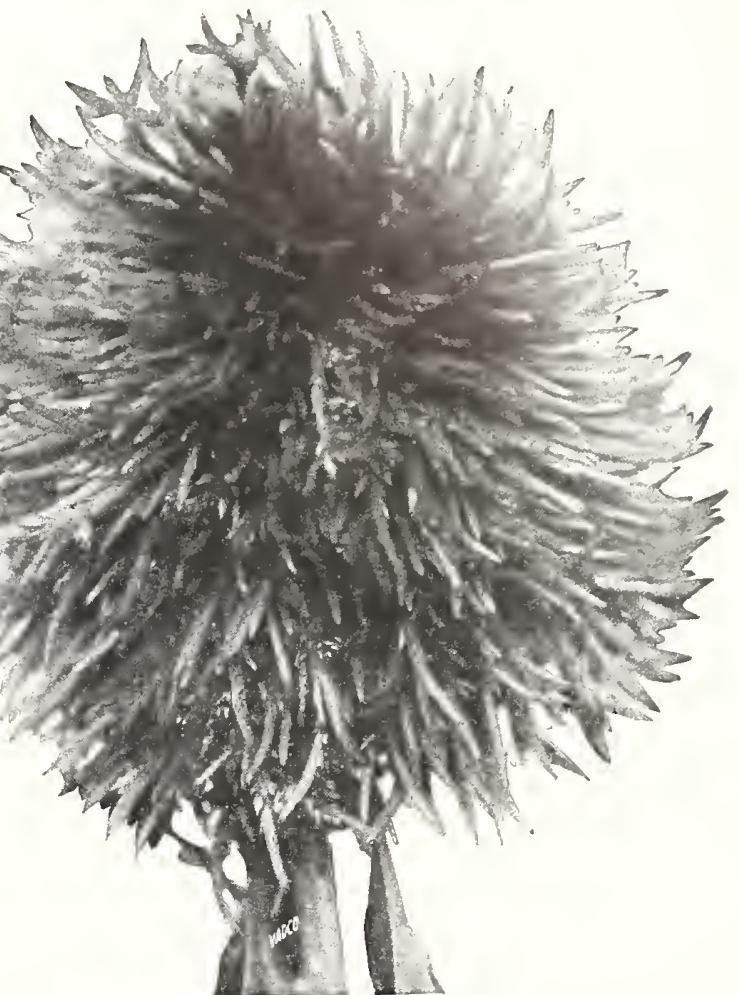

Profit-Sharing Certificates with Every Order See Page 3 DELPHINIUM-Continued

No. 2542-Bellamosum- This is a rich the popular light blue Belladonna, having the same
free-blooming and other good qualities. Pkt. $25 \mathrm{c;}$; No. 2525-Datura (The T r u m p e t Flower) — A grand annual plant. The flowers aver. French white inside, purple outside; delighttully fragrant Started early, will flower from early summer until fall No. 2580-Digitalis (Foxglove). P.Stately, old-fashioned border plants, affording dense spilkes of large billiantly colored flowers, which are terminal
and half as long as the height of the plant. The flowers are very distinct and showy, being thimble like or long rose, many being spotted or blotched.

Vadco Prize Mixed. Many shades and markings. Plt $10 \mathrm{c} ; 3$ pkts. $25 \mathrm{c} ; 1 / 4$ oz. $40 \mathrm{c} ; 1$ oz. $\$ 1.25$.

\section{SPLENDID PORCH CLIMBERS No. 2508}

No. 2303-Cardinal Climber. A.Without a doubt is the most brilliant and new anyears; growing rapidly and blooming profusely, very a rich glowing scarlet. Pkt. 15c; 2 pkts. 25c. No. 2500-Cypress Vine. A.-

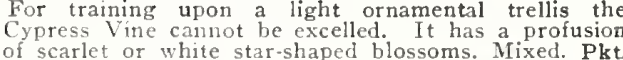
No. 2430 - Convolvulus. A. These beautiful annual climbers are of easy culture
and produce freely all summer. Major Mixed ColNo. 2417-Cobaea (S c a n d e n s Cathedral Bells). A. - One of the hand. growing climbers. The flowers are bell-shaped and open a clear green but turn a beautiful purplish lilac. Seed should be sown edge
and prolific bloomer. Pkt 10c. 1 packet each the above 4 choice climbing annual
fowers all for $30 \mathrm{c}$, postpaid. Collection No. 2508 . 


\section{ESCHOLTZIA, A.}

\section{California Poppies or Golden Cups}

This beautiful and brilliant annual has been greatly improved in recent years, and we

Fully as valuable as the common Poppy for garden ornamentation since the flowers are in bloom through a much longer season. The foliage is finely cut, delicate and very attrac.

Seed may be sown at any time during the spring, the earlier the better where they are a drow nicely and bloom profusely position $A$ subject for beds of any size or as a border. their finely cut, blue-green foliage, and glossy flowers of satin-like texture, make them one

No. 2590-California Superb Mixed- An excellent mixture producing

deep yellow, creamy white, scar.
No. 2591-Orange.
No. 2593-Golden West
No. 2595-Rose.
No. 2597 -Crimson.

Each, per packet, 10c; I packet each the four colors for 30c, postpaid. Collection No. 2598.

No. 2602-Fuchsias (Lady's Eardrops). are always general favorites, The seed we offer is saved from a fine collection of double

No. 2600-Four O'Clock (Marvel of Peru). A.- - Showy. erect bushy habit. Vadco Mixture. Pkt. 5c; 6 pkts. 25c; oz. 40c.

Gaillardia. P.—

h brilliant flowers, in scarlet

summer till autumn. Grows one alossoms

are borne on long, slender stems. Both single and double varieties are hardy.

No. 2610-Vadco Perennial Varieties Mixed-Pkt. 10c; 3 pkts. 25c; 1/2 oz. 50c

No. 2620-Double Mixed Annual (Picta Lorenziana)-A. Pkt. 10c; 1/4 oz, 25c.

Gypsophila (Baby's Breath) -

No. 2630-Geraniums. P. - Thisese popular plants are most easily produce flowering plants the first summer. Start in the house and transplant to the No. 2631-Gerbera (Transvaal Daisy). P.- A beautiful ing plants brought into prominence with the introduction of an improved large-flow. ering scarlet type. They are half-hardy perennials, usually grown as greenhouse or

Giant Scarlet. Flowers 3 to 4 inches acruss, on 2 to 3 foot stems; color intense Pretty free-flowering elegant plants, succeeding in any garden soil. Their misty white panicles of bloom are largely
used for mixing with other cut flowers. Most easy to grow; 2 to 3 feet. No. 2659-Paniculata (Baby's Breath). P. - An elegant hardy perennial plant that should be but its delicate little flowers, produced in feathery white panicles, and branching foliage lend a daintiness to bouquets that is most elegant. Pkt. 10c; 1/2 0z. 35c; oz. 65c.

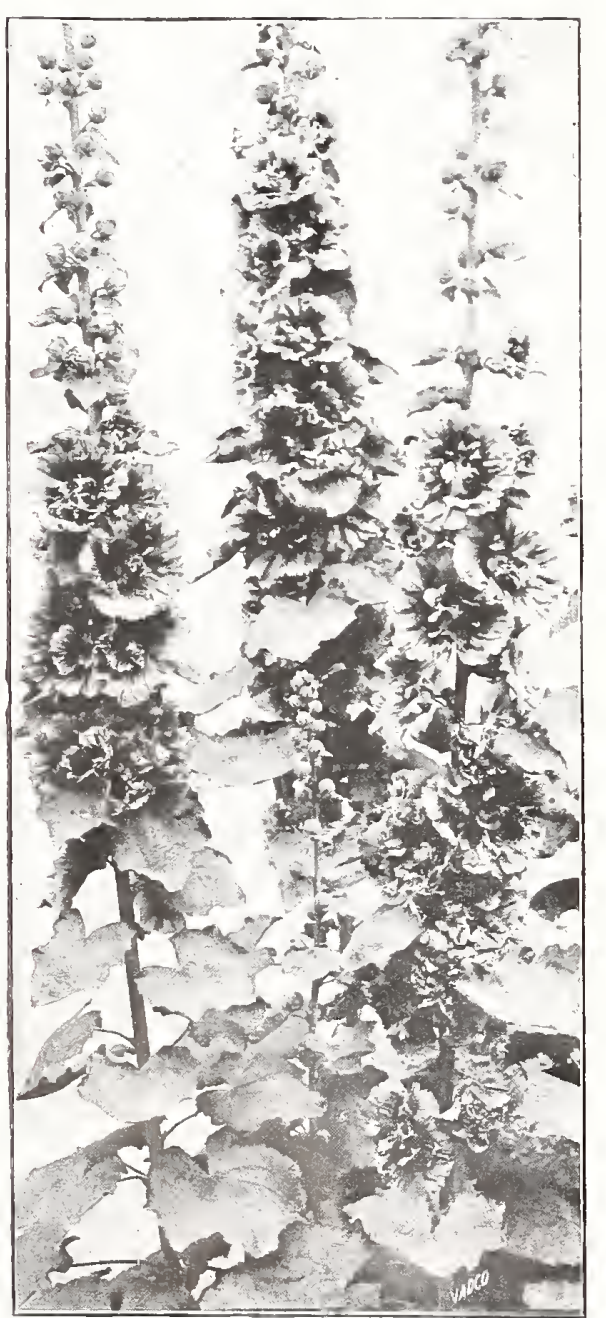

Single Fine Mixed Hollyhocks No. 2710

No. 2661_-Annual Variety Elgans grandiflora alba.— This is an improved, large-flower. Baby's Breath; of free, easy growth. Pkt. 10c; 1/2 oz. 25c; oz. 40c.

No. 2640-Godetia. A.- The plants bloom profusely, and bear snowy flowers, not unlike an Azalea, of attention, being a splendid bedding plant. Vadco Assorted Colors, Mixed Dwarf. Pkt. 10c; 3 pkts. 25c; 1/2 oz. 50c.

Gourds Ornamental. A._- Favorite annual climbers, of rapid growth, having luxuriant foliage and being No. 2650-Mixed Ornamental Varieties. Small sorts. Pkt. 10c; 1/2 oz, 30c.

The following separate varieties of Gourds. Each per packet, 10c.
No. 2651 -Calabas
No. 2653 -Dipper.
No. 2655-Dish Cloth.

No. 2670-Helichrysum (Everlasting Straw Flower). A. - - Is the best and most satisfacand makes a very handsome dried bouquet; 3 to 4 feet. Exceedingly effective double Howers in rich glittering colors, making a fine display in beds or borders, but especially grown to dry and use in baskets and vases through the winter: when wanted for this purpose they should be cut with as long stems as possible, and when the blooms are about one. ceed in any good garden soil; give them plenty of room to develop, planting not closer than 12 inches apart; hardy
annuals. All Colors Mixed. Pkt. $10 \mathrm{c} ; 3$ pkts. 25c; $1 / 2$ oz. $40 \mathrm{c}$. No. 2680-Heliotrope. P.- Well known and admired garden favorite. Grows about $11 / 2$ feet high and cellent for massing or for growing in pots or boxes. Mammoth Flowering Mixed. Pkt. 10c; 3 pkts. 25c; 1/2 oz. 75c.
No. 2690-Hibiscus (Mallow Marvels). P.- New large-flowering hybrids. Although they
are perennials they flower the first year from seed. The blooms are wonderfully large, 6 to 7 inches across, and the whole plant is extremely showy. Pkt. $10 \mathrm{c}$; 1/4 oz.
$25 \mathrm{c}$; oz. $65 \mathrm{c}$. No. 2725_Humulus (Japanese Hop). A._- Japonicus Varigatus. The leaves are variegated climber of quick growth, and very ornamental. Not attacked by insects, and valuable for covering verandas, fences, No. 2723-Honesty (Lunaria biennis) (Satin Flower; Money Plant). P.The flat silvery seed pods are used for winter decoration in the house; pretty and different from anything else; 2 feet.

\section{HOLLYHOCKS. P.}

Some grow to the top of the second-story window and in some gardens they only grow 8 to 10 feet tall. The double ones are usually about 6 feet tall. The beautiful color effects produced by the planting
of these flowers, combined with their dignified and stately appearance, render them indispensable for either of these flowers, combined with their dignified and stately appearance, render them indispensable for either
the old-fashioned garden or the well-planned herbaceous border. As a background for other flowers or
planting among shrubbery, they are without an equal. As the plants are affected with rust occasionally, No. 2700-Vadco Farms' Choice Double Mixed—_ Pkt. 10c; 3 pkts. 25c; 1/4

No. 2710-Single Fine Mixed-(See illustration.) Pkt. 10c; 1/4 oz. 50c.

No. 2720- Hollyhocks (Annual Everblooming). A. - New strain which year from seed. In every way the same as the hardy varieties with the additional advantage of a
longer blooming period. Pkt. 15c;2 Dkts. 25c. 


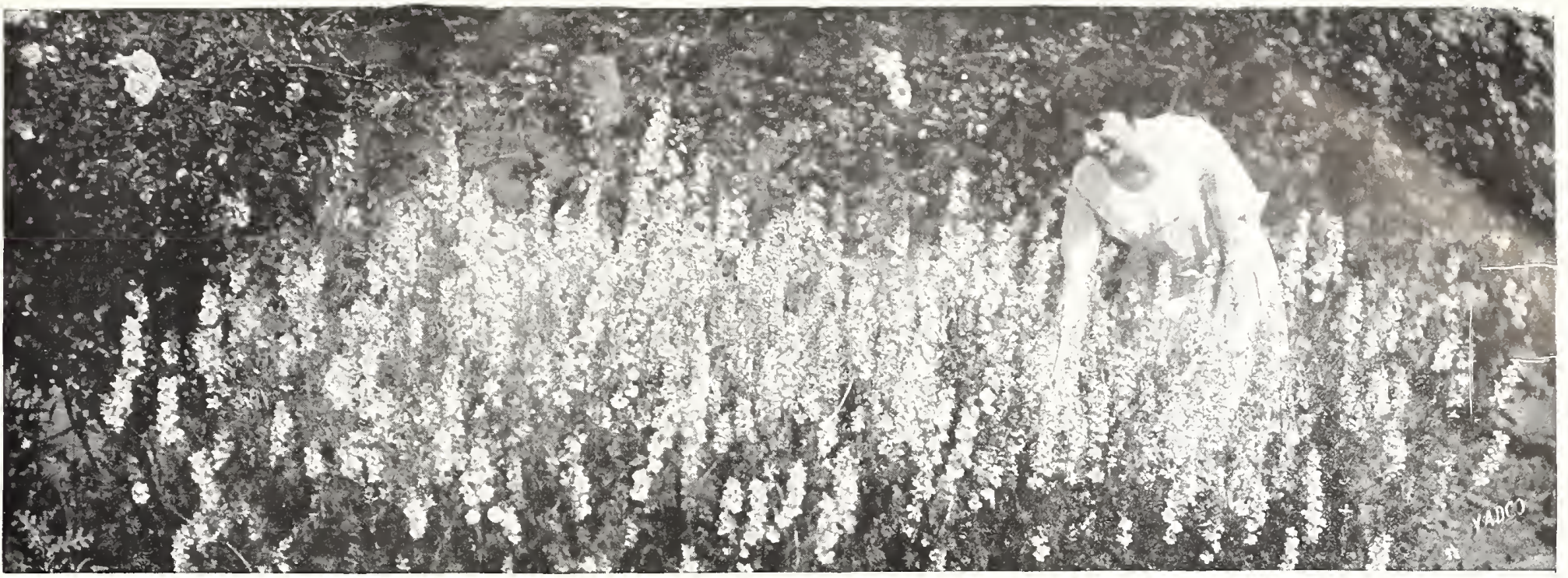

No. 2750-Larkspur. A.— Well known rapid growing annual with long erect spikes of beautiful double flo
No. 2751 -White.

No. 2727-Ice Plant. A.- A curious and very ornamental little plant part of the leaf and stalk being covered with small watery pistules, which glisten in succeeds well even in dry places. Pkt. $10 \mathrm{c} ; 3$ pkts. $25 \mathrm{c}$. No. 2740-Lantana. P.- One onial greenhouse or bedding plants, constantly in bloom; Verbena-like heads of orange, white, rose and other colored flowers: No. 2765-Lavender. $\mathrm{P}^{2}$ - We 3 Well-known, sweet-scented, hardy peren mixed horder. 3 fet. Plendensively grown in the Lobelia. P. Exceedingly pretty, profuse-blooming plants of great value. vases, especially prized for edgings of beds and borders. Plants grow about 6 inches ho. $770-$ are treated as annuals and are of the easiest culture.

No. 2771-Crystal Palace (Speciosa)-An exceptionally' graceful sort and one of the best in color, having bright deep blue flowers, very dark green foliage. Pkt. 10c: 3 pists. 25c.

No. 2815-Matricaria (Feverfew). P.- Half-hardy perennial, treated as an annual. Double, pure white flowers are borne on slender stems 15 No. 2824-Mimosa (Sensitive Plant) - The le a ves instantly Mimulus (Musk Plant) - Litle plants, with singularly shaped and conceivable manner. Excellent for baskets or vases.
No. 2817- Moschatus, or Musk Plant-Fragrant plant, with small, yellow blooms, spotted lightly with brown. Pkt. 10c; 3 pkts. $25 \mathrm{c}$.
No. 2819-Tigrinus, or Monkey Flower-Large flowers of several colors and spotted. Myosotis (Forget-me-nots). P.— The Forget me-not is an old faclusters of star-shaped flowers. Succeed best in a moist, shady situation, and bloom No. 2840-Vadco Farms' Finest Mixed-8 in. Pkt. 10c; I/8 oz. 30c.

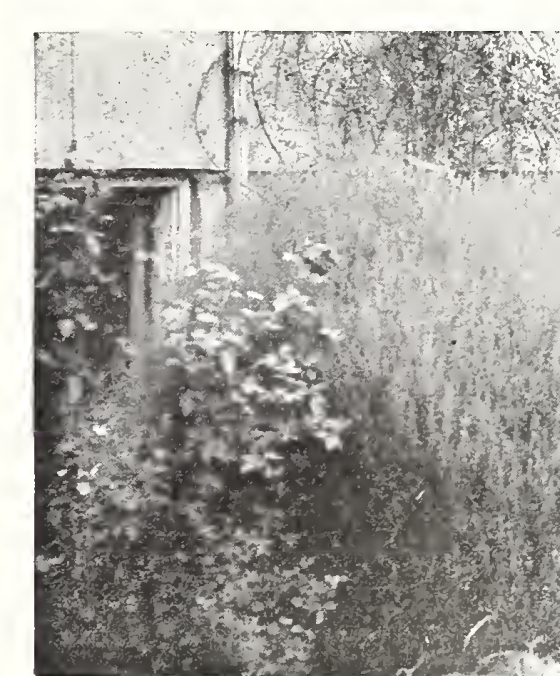

No. 2841-Blue Alpestris (Forget-me-nots) _ ${ }_{c}^{\text {Plants of }}$ - of bushy habit with finely cut foliage, growing 6 to
a very small yellowish eyc. Pkt. $10 \mathrm{c} ; 3$ pkts. $25 \mathrm{c}$

\section{BEAUTIFUL CLIMBERS FOR THE FRONT OF YOUR HOME-No. 2828}

No. 2729_Jack-and-the-Beanstalk - Mudzu Vine). M.No. 2731-Jack Bean, or Hyacinth Bean, Dolichos. A. - Rapid growing and free fowering annual climber, grow-

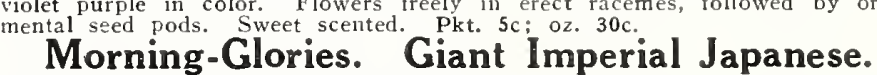

One of the most valuable and popular annual climbers introduced celebrated for the beauty of both flowers and foliage. Magnificent in size and bloom-4 to 6 inche

No. 2816-Mexican Coral Vine- The Me i i c a n Cor feet in length of a beautiful red color. The foliagc is light green. It blooms

No. 2827-Blue Moonflower- Flowers very large and of a purple rays. There is nothing in a blue color excelling the shade of the
"Heavenly Blue." Pkt. 10c.
Special offer. 1 packet each of the 5 splendid climbers listed above

You can also have a pretty row of these Kochias or Burning Bushes in the front of your home

No. 2735-Kochia or Burning Bush-

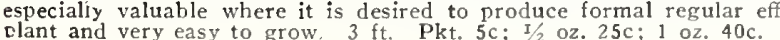




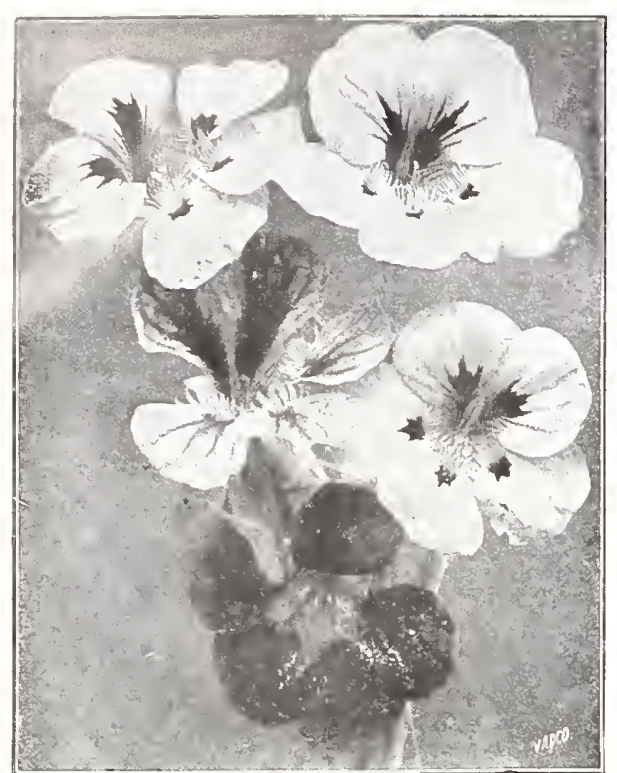

\section{MARIGOLD. A.}

The African and French Marigolds are old favorite free-flowering annuals of easy culture; both are extremely eftective. The former well adapted for large beds or mixed borders; the latter are dwarfer in growth, with beautifully striped flowers, and are better best in a light soil, with full exposure to the sun.

No. 2790-Vadco Farms' Mixiure of Tall

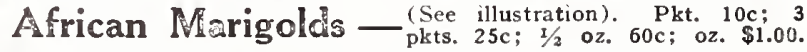
No. 2791_-African Orange— Large, perfect double. rich deep golden-orange color; the finest of all and very showy. No. 2793-African Lemon-A counterpart of color, which is a soft lemon-yellow. Pkt. 10c; 1/4 0z. 35c, No. 2800-French Marigolds. A. Double Dwarf Mixed - Finest assortment saved from prize flowers. No. 2810-French Marigolds Double Tall Pvired-Grows 2 feet high with very large flowers which are
finc for cutting. Pkt. $10 \mathrm{c} ; 1 / 4$ oz. $30 \mathrm{c}$.

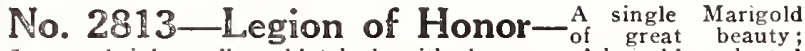
flowers bright yellow blotched with brown. Admirably adapted Vadco Mammoth Dwarf Nasturtiums No. 2850 MIGNONETTE. See page 41.

\section{VAN ANTWERP'S NASTURTIUMS. A.} NEW MAMMOTH FLOWERING SORTS

Our VADCO Mixtures of Nasturtiums are made up out of the best named sorts, insuring a large number of colors.

Nasturtiums have flowers measuring three inches across, in a great variety of new and charming combinations of colors, while the brilliancy and velvety richness of the self-covered sorts have been greatly enhanced. For summer flower-beds nothing can surpass them: the plants form perfect mounds about one foot high by one foot across. Secd sown in the open ground in the spring will produce plants that commence blooming during early summer and con tinue until frost. (See illustration).

\section{MIXED NASTURTIUMS}

No. 2850-Vadco Farms' Mammoth Flowering Dwarf Nasturtiums, Mixed These wonderful new Nasturtiums produce flowers twice
the size of the old-time dwarf mixed. Pkt. Sc; oz. 10c; $1 / 4$ No. 2860-Vadco Farms' Mammoth Flowering $\mathrm{Cl}$ i m b i n $\mathrm{g}$ Nasturtiums,

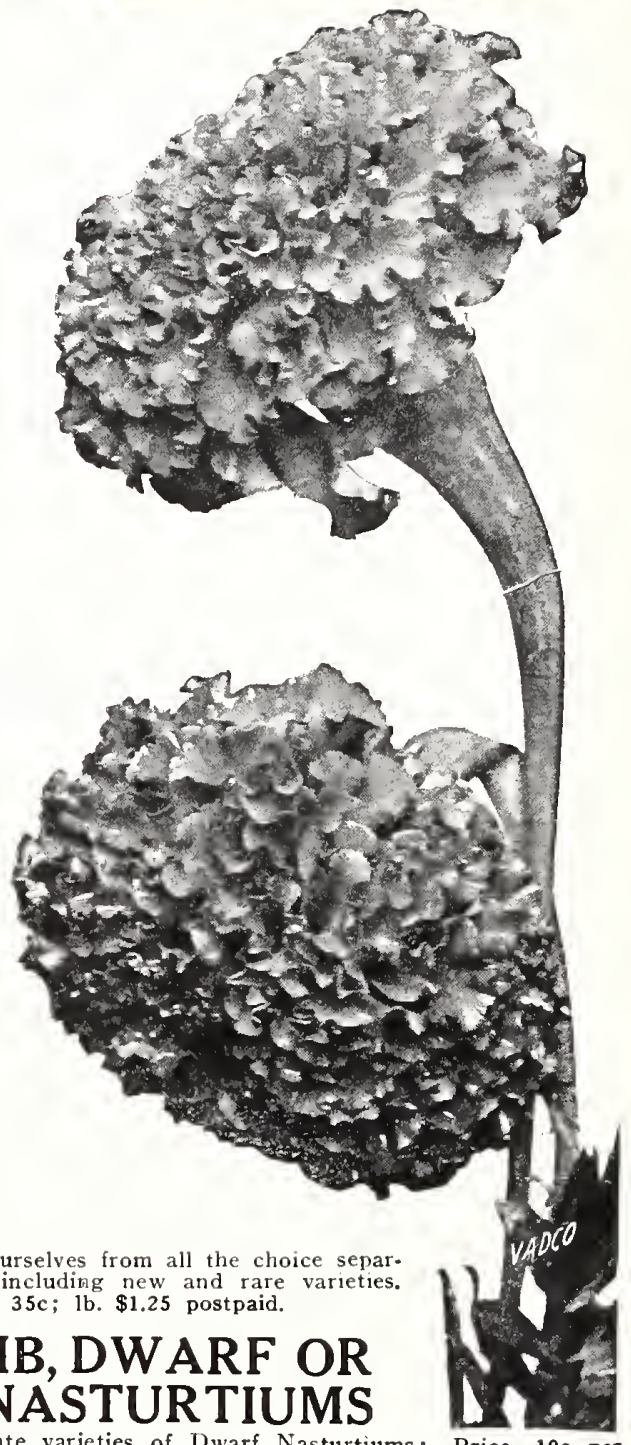

Mixed-Mixed by ourselves from all the choice separ Pkt. 5c; oz. 10c; 1/4 lb. 35c; lb. \$1.25 postpaid.

\section{TOM THUMB, DWARF OR} BEDDING NASTURTIUMS

pkt. any 3 for $25 \mathrm{c}$; $20 \mathrm{c}$ per oz. any variety.
No. 2851 -Aurora-Chrome yellow blotched crimson.

No. 2853-Beauty-Scarlet splashed canary.

No. 2854-Cloth of Gold-The foliage is of bright yellow, while the flowers No. 2855-Empress of India-Fiery crimson, dark foliage.

No. 2856-Golden King-Rich golden yellow.

No. 2857-King Theodore-Deep crimson maroon, dark foliage.

No. 507 - Collection-1 packet each the 6 varieties of Dwarf Nasturtium

\section{TALL OR CLIMBING NASTURTIUMS}

Elegant and luxurious climbers' for verandas, trellises, etc. The folloning sepaus climbre fort.

No. 2861-Chameleon-Different richly colored flowers on the same plant. No. 2865-King Theodore-Deep crimson

No. 2867-Moonlight-Creamy white.

No. 2863-Sunlight-Pure rich butter-yellow. the trailing and climhing class with exquisite beautiful foliage and very No. 509-Collection. I pkt. each the 6 varieties of Climbing Nasturtiums mailed postpaid for $40 \mathrm{c}$

\section{VAN ANTWERP'S PANSIES. P.}

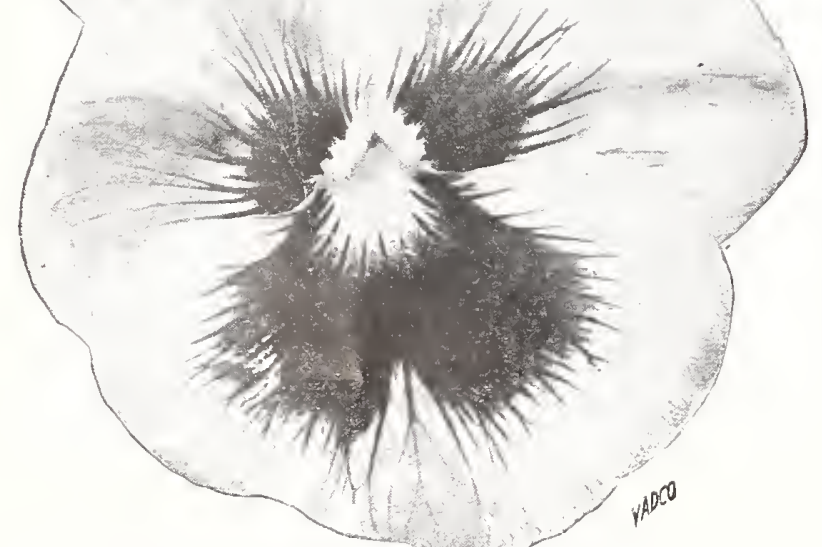

Vadco Exhibition Mixed Fansies No. 2920

Pansies thrive best in a rich soil, and cool, moist situation; they do splendidly in partially ander trees, but in some locations where the sun strikes only part of each day the most satisfactory result can be obtained. Seed sown from July to September. give the most unbounded satisfaction to amateur and professional grower alike.

No. 2920-Vadco Farms' Exhibition Mixed. P.— The result of years of ing Pansies have gradually evolved a superior race of luxuriant robust growth and deep-rooting, form and colors. (See illustration). Pkt. 25c; $3 / 8$ oz. $\$ 1.50$.

No. 2930-Royal Mixture. P. - This mixture comprises a large number of colorings mixture at a modcrate price. Pkt. $15 \mathrm{c} ; 2$ pkts. $25 \mathrm{c} ; 1 / 8$ oz. $\$ 1.00$.

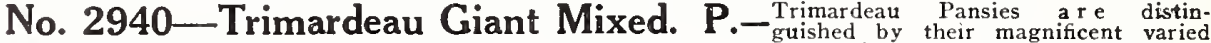
colors and strong markings. The flowers are of mammoth size and of great substance. Pkt. 10c $1 / 4$ oz. $75 \mathrm{c}$; oz. $\$ 2.50$.

No. 2914 Ornamental Grasses_ These are splendid for vases or for mixing in No. 2914 with other flowers in bouquets; they can also be dried for winter bouquets. If to be used for that purpose, they
matured and then hung up to dry. Pkt. 10c; 1/2 oz. 25c; oz. 40c.

No. 2825-Moonflowers. A. - They are popular everywhere in the South as climb. No.
A. ers for shade on porches, trellises and arbors. They make a rapid growth and a dense shade, protecting porches from the hot rays of the sun. They grow
20 feet high. White. Pkt. $10 \mathrm{c} ; 3$ pkts. $25 \mathrm{c} ; \mathrm{I} / 2$ oz. $60 \mathrm{c} ; 1$ oz. $\$ 1.00$. 


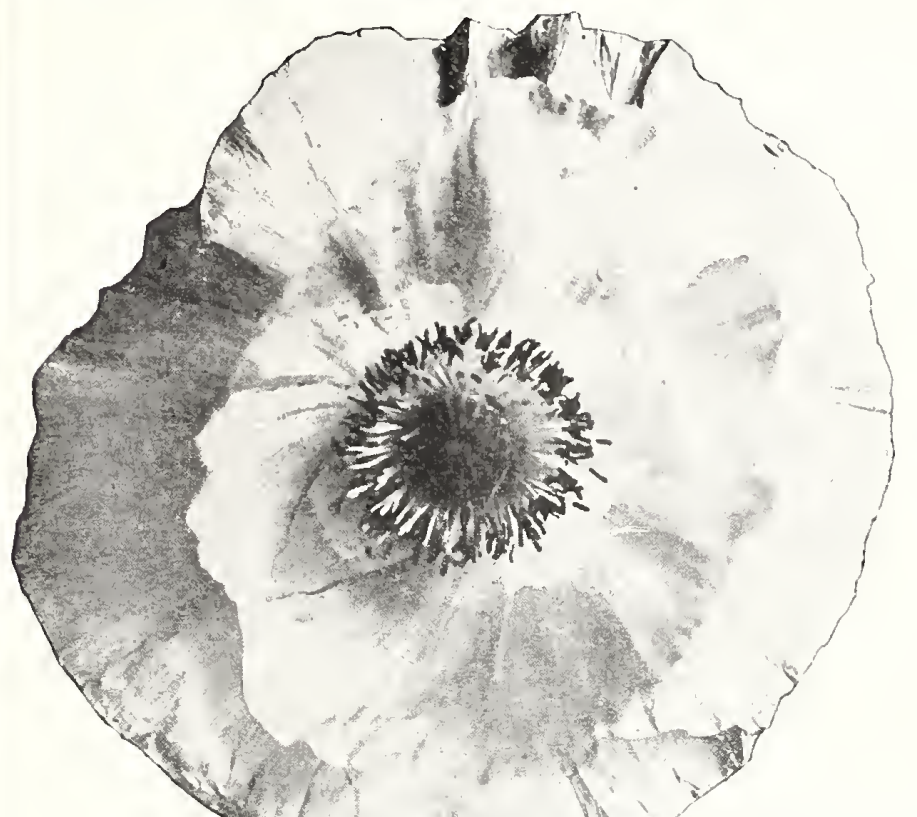

\section{LARGE FLOWERING PETUNIAS}

Petunias are very showy annual flowers and bloom continuously all summer. For garden beds, window or porch boxes these beautiful flowers have no equal. The petunia seed we offer Sow the small seeds in a warm, sunny, open place outdoors, thinning to 15 inches apart, on
in frames for transplanting. Scatter seeds thinly, barely cover and firm soil over them; wates seedlings with a fine spray to prevent drying out. The weakest looking seedlings usually produce

\section{BALCONY OR BEDDING PETUNIAS}

The following separate colors in Bedding Petunias:

No. 2971-Bedding White. No. 2972—Bedding Pink.

No. 2973-Bedding Crimson. No. 2974-Bedding Blue.

Price: Any of the above varieties of Bedding Petunias, pkt. 10c; special Collection No
2978, 1 pkt. each of the 4 separate colors for 30c, postpaid.

No. 2950_Vadco Fancy Fringed Mixed-_ A mixture of best fringed varie. new colors and shades. Should be grown by everyone desiring the best. Pkt. $15 \mathrm{c} ; 2$ pkts. 25c;

No. 2980_Double Fringed Mixed_- A superb mixture of the finest doublerepresented. Splendid for borders or beds, keeping up a succession of bloom througbout the

No. 2975-Bedding Mixed- A fine mixture of the newer varieties of bedding petunias con.

Vadco Single Shirley Poppy No. 3030

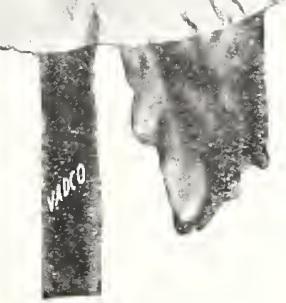

No. 2960-Finest Striped and Blotched Single_- Includes striped or blotched flowers in : Pkt. $10 \mathrm{c} ; 1 / 8$ oz. $50 \mathrm{c}$.

No. 2963-Howard Star- The flowers of medium size, rich crimson maroon, with bluish white stripe

No. 2970_Single Mixed Petunias_Pkt. 10c; 1/4 oz. 50c; 1 oz. \$1.50.

\section{BRILLIANT POPPIES}

Poppies are extremely popular in the South and grow easily. The many brilliant colors make them very effective for beds or borders. Sow the seed where the plants are to remain as they will not stand transplanting.

No.3030-Vadco Farms'Shirley Finest Single Mixed. A. Dainty flowers on slender stems, in the most delicate shades, varying in color from pure white and delicate pink to rosy carmine and deep crimson, many of them
beautifully striped and edged with white. (See illustration.) Pkt. 10c; $1 / 4$ oz. $25 \mathrm{c} ;$ oz. $75 \mathrm{c}$.

No. 3040_Double Carnation-Flowered Mixed. A.A fine strain of double, fringed Poppies with flowers about the size of a large carNo. 3050-Double "Featherball" Mixed. A.- T h e s e fringed annual Poppies are very beautiful; with gracefully fringed-edge petals like big balls of slashed tissue paper or feathers. Pkt. $10 \mathrm{c} ; 1 / 4 \mathrm{oz}$. $25 \mathrm{c} ; 1 \mathrm{oz} .75 \mathrm{c}$

No. 3053-Wild French Poppy- (The Poppy of Flanders.) A. The tell about as they saw it in a riot of color among the rye and through the grainGelds of France. Pkt. 10c; $1 / 4$ oz. 25c; 1 oz. 75c.

No. 3070-Orientale (the large Oriental Poppy).A hardy plant, bearing large, brilliant crimson flowers, with a black blotch on each petal. Pkt. $15 \mathrm{c} ; 2$ pkts. $25 \mathrm{c}$.

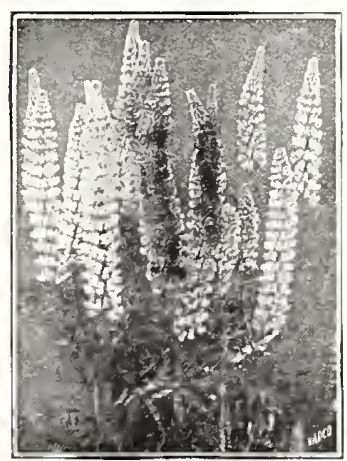

Lupinus No. 2780

Lupinus. A. Free-flowering, nuals, with easily - grown an and various colored pea-shaped flow. ers; valuable for mixed borders, beds and for cutting; prefers a little shade; grows 2 feet high.

No. 2780-Vadco Finest Mixed-Pkt. $10 \mathrm{c}$ : oz. $35 \mathrm{c}$.

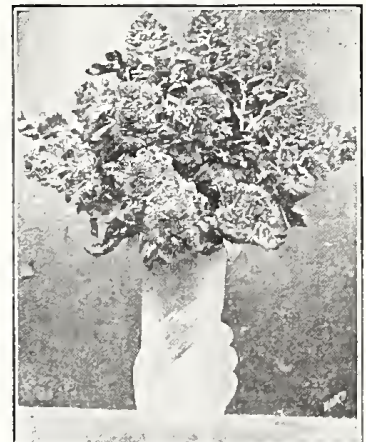

Mignonette No. 2820

Mignonette. A. A well-known producing dense cone-shaped flowerspikes.

No. 2820-Vadco Sweet Scented Mixed -Plit 10c; 3 pkts. $25 \mathrm{c}$; $1 / 2$ Oz. $50 \mathrm{c}$ 1 oz. $85 \mathrm{c}$.

No. 2821-Machet-This is one of the very best for pot culture. Pkt. $10 \mathrm{c}$; $1 / 4$ oz. $25 \mathrm{c}$.

\section{GARDEN PINKS or DIANTHUS}

Hardy annuals, about one foot high, and bearing beautifully colored singie and double blossoms in profusion all summer. Sow seed early in boxes and tran. No. 2550-Vadco Fancy Double Mixed- ${ }_{250}^{\text {Pkt: } 100 ; 3 \text { pro. }}$ No. 2560-Heddewigii- (Japanese Pink.)-Finest single, mixed. Pkt No. 2570-Vadco Plumarius - G Grass Pink, Pink.) $\begin{gathered}\text { Pheasant Eye or } \\ \text { Sh. }\end{gathered}$

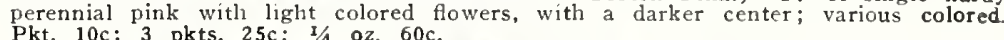
3 CHOICE ANNUAL FLOWERS No. 2890-Nemesia. A. - Nemesias come 1 foot high and are a mass Mixed. This has flowers in light.blue, red, yellow and terra.cotta. Pkt. $15 \mathrm{~s} ;$; 2 No. 2900-Nemophila, or Love Grass. A.— flower, growing about 6 inches high. Has small cup-shaped blossors about one No. 2901 - Nicotiana, or Flowering Tobacco. A. A hardy annual, growing 3 feet high, with slender tubular flower. Belongs to the tobacco family. Requires plenty of room in the garden. Affinis. White and very
fragrant. Flowers open in evening and cloudy days. Pkt. 10c; I/4 oz, 25c. 


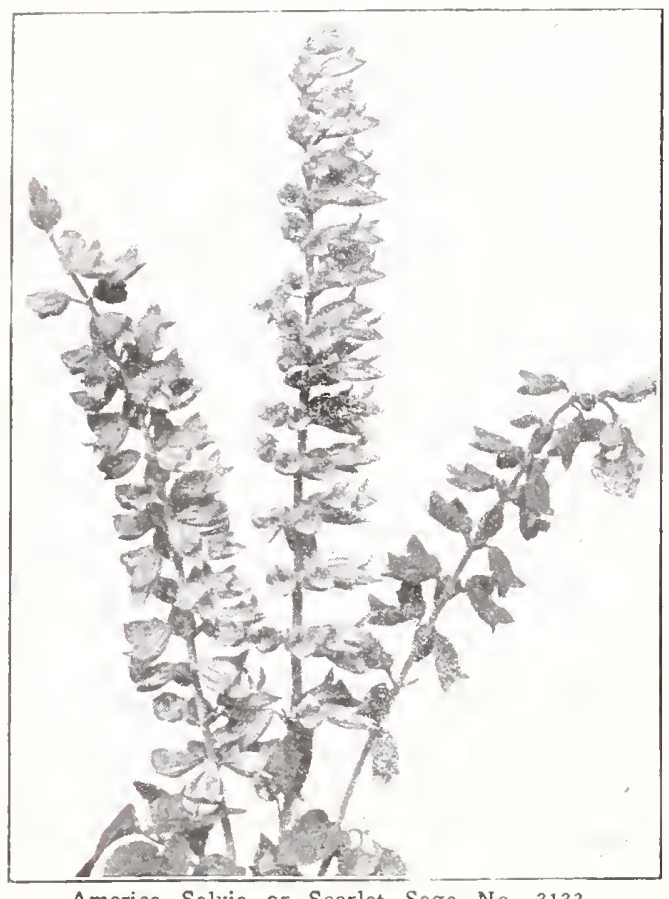

No. 2990-Pentstemon. P. -

No. 3100-Primrose-

Want varieties, average $41 / 2$ to No. 3103-Pyrethrum-Aureum, or Golden Feather. P. Small-cut No. 3120-Ricinus

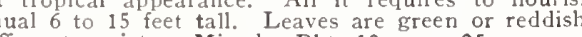
No. 3123-Rudbeckia Golden Glow. A. A - Bicolor Superba Produces an abundance of bright yellow flowers with brown central disc; fine No. 3130-Salpiglossis. A. - A half-hardy annual, growing about No 3137 -Scarlet Runner beans of excellent quality, either when shelled or No. 3145-Smilax. P.- Graceful perennial climber with smal1 heart.

STOCKS. Ten Weeks Stocks, or Gilliflowers.

No. 3150-Vadco Farms' Large-Flowering Ten Weeks. A - Our strain of these has great rosettes set closely together so that the entire

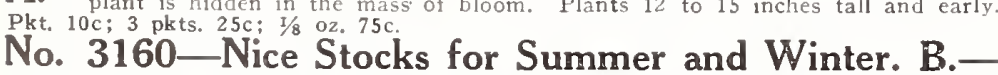
Tall stocks nicely branching, having large double flowers, not tightly clustered bu

\section{OLD FASHIONED WALL FLOWERS} The kind they had in Grandmother's Garden

No. 3260-Vadco Large Double Mixed Colors-Pkt. 10c; 3 pkts. 25c.

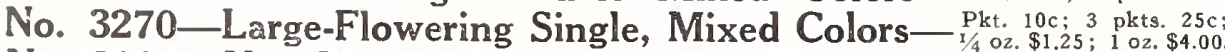
No. 3280-New Wall Flower- Extra early annual. These flower the first season irom

\section{SWEET WILLIAMS}

No. 3180 - Vadco Farms' Single Mixed- (See Tllustration.) All colors. Pkt.

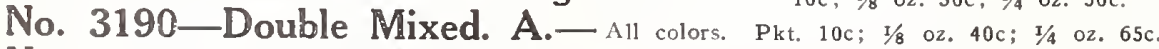
No. 3200-Annual Mixed. A. - In appearance and habit the same as the perennial

\section{MAMMOTH VERBENAS}

No. 3230-Vadco Farms' Mammoth Mixed_- Finest colors. Pkt. 10c; 1/2 oz.

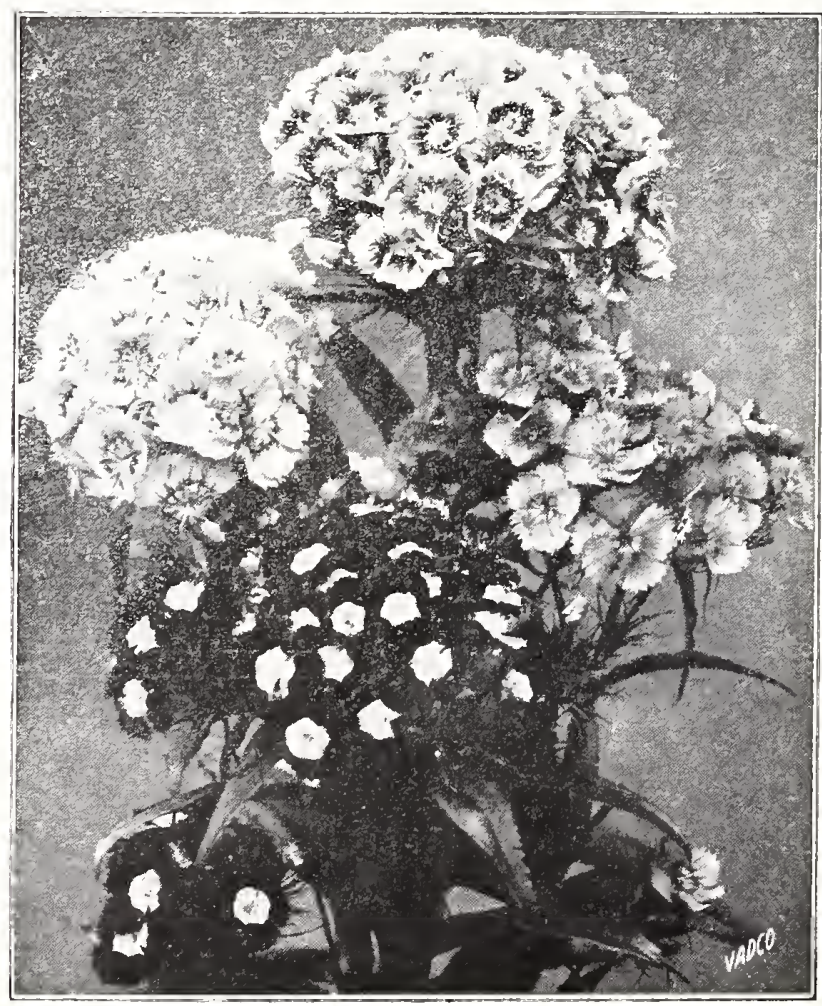

Vadco Single Mixed Sweet Williams No. 3180 
WONDERFUL NEW ZINNIAS

\section{ILLUSTRATED IN NATURAL COLORS ON OUTSIDE BACK COVER}

flowered varieties eclipse gro the perfection in the South wish to call attention to our very large list of separate colors which includes every conceivable color and variety. Our Zinnias are grown especially for us by an expert CaliSouth and can be grown in any good garden soil, but we recommend a liberal supply CULTURE-Sow the seed in early spring in good soil. Thin out or transplant

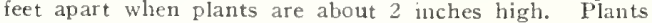

New--Double Dahlia-Flowered Zinnias

The flowers have a very marked distinction from the ordinary giant-flowering class, being of a true Dahlia-Rowering type, and when cut from the plant and placed by Dahlias
it is difficult to distinguish one from the other. Of easy culture, very large flowers, free

No. 3301-Purple Yrince-A lovely new large purple Dahlia Flowered

No. 3302 -Illumination- Similar to Exquisite, but a striking self color of

No. 3303-Salmon Beauty - A newed salmon colored Zinnia, rzal Dahlia

No. 3304-Exquisite- The fowers resemble a large Decorative Dahlia. deeper rose in the center. Pkt. $25 \mathrm{c} ; 2$ pkts. $40 \mathrm{c}$. No. 3306-Golden State- An excellent color. Rich golden yellow, shad. No. 3307-Scarlet Flame- Rich orange-scarlet. A most dazzling color.

No. 3307 lavender No. 3309_-Polar Bear- This is decidedly the finest of all white Zinaias. Price-Your choice of any the above 9 varieties of new Dahlia Zinnias: Pkt. 25c: No. 3300 - Vadco New Dahlia Flowered Mixed- (See illustra. from the above 9 new varieties of Dahlia Flowered Zinnias. Pkt. 15c; 2 pkts. 25s;

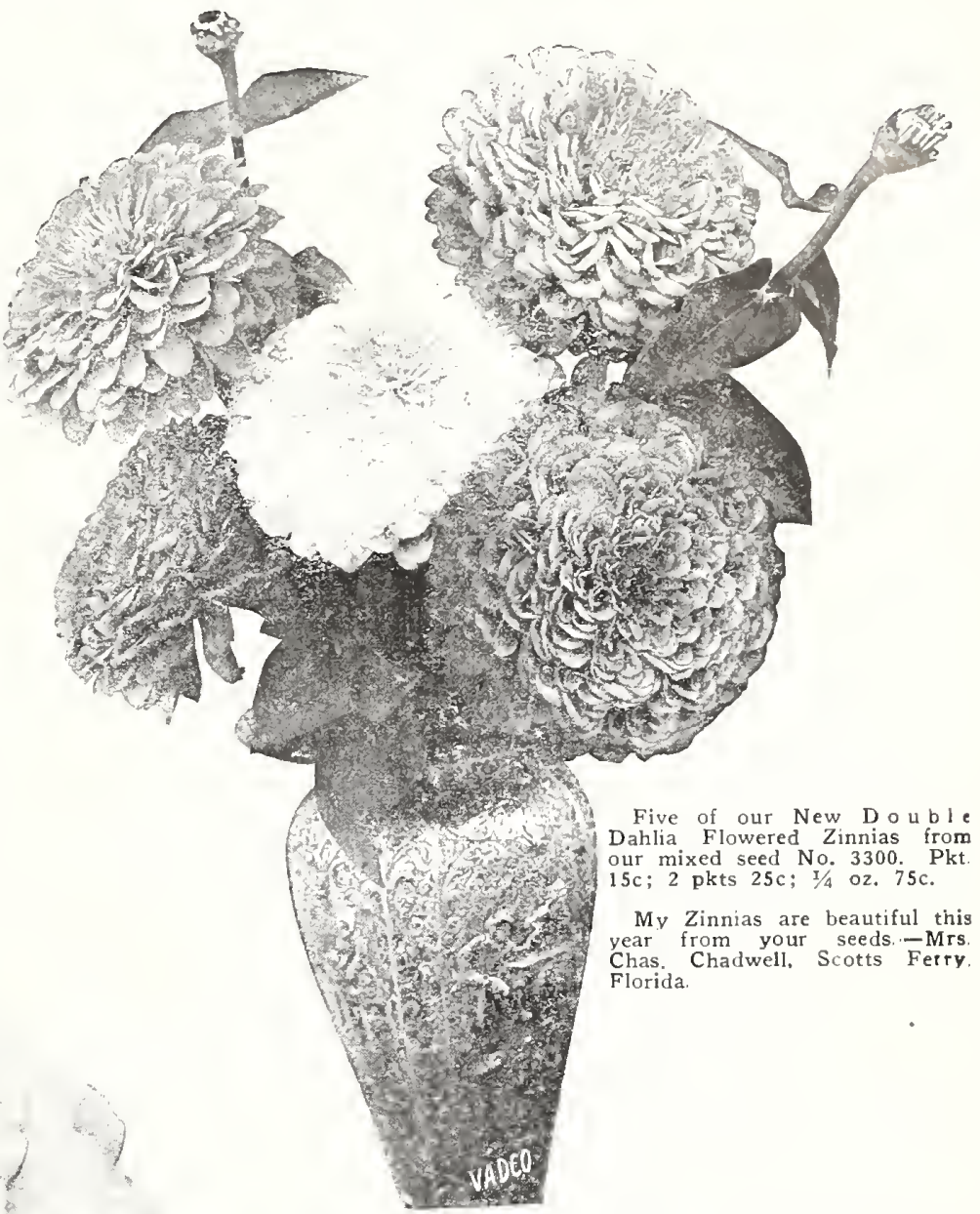

\section{Van Antwerp's Giant} Zinnias

The following separate colors of GIANT ZINNIAS These are the large double Zinnias and our selection o $10 \mathrm{c} ; 3$ pkts. $25 \mathrm{c} ; \mathrm{I} / 4$ oz. $50 \mathrm{c} ; \mathrm{1} / 2$ oz. $\$ 1.00 ;$ oz. $\$ 1.75$.

No. 3321-APRICOT, BUFF

No. 3342-PICOTEE

No. 3323 - BRIGHT ROSE

No. 3324-CANARY YELLOW

No. 3325-CRIMSON

No. 3338-GOLDEN YELLOW

No. 3326-DEEP FLESH

No. 3327-LAVENDER

No. 3329-PURPLE

No. 3331-SALMON ROSE

No. 3334-SCARLET

No. 3335-SHRIMP PINK

No. 3336-WHITE

No. 3344-BURNT ORANGE

No. 3343-NEW ORANGE KING

\section{5}

Packets

\section{PRIDE OF THE SOUTH} Zinnia Collection No. 525

\section{This is a wonderful collection of Gian}

Zinnias, consisting of 1 packet each of the

packets mailed postpaid all for $\$ 1,00$

Order collection No. 525

Our grower in California When sending us the above

that this is the kind of blooms he select when saving Zinnia Seed for Van Ant werp's.
Il the seeds came up and did fine, considering the dr blooming.-Mrs. Jerry Oliver, Moss Point, Miss.
No. 3310 - Vadco Giant Zinnias Mixed Colors - This is a mixture of all the 


\section{VAN ANTWERP'S SWEET PEAS GIANT-WAVED SPENCERS}

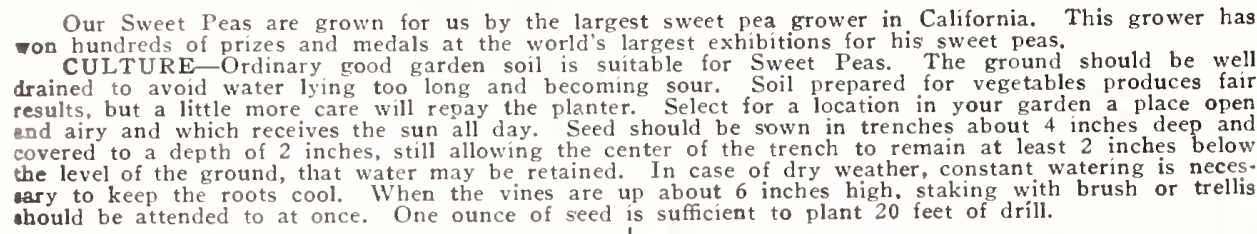

Separate Colors Spencer Sweet Peas

\begin{abstract}
Some of our customers prefer to get sweet peas
in separate colors and we have selected the following named varieties which we consider the best. Each per packet
$\$ 1.00 ; 1 \mathrm{l}$. $\$ 3.50$.

No. 3403-Blanche Ferry-Pink and White.

No. 3402-Crimson King. A rich deep Crimson.

No. 3405-Elfrida Pearson. The finest and largest

No. $3410-$ George Shawyer. Beautiful orange pink.

No. 3407-Hebe. Large light pink

No. 3419-Jack Cornwall. A lovely dark blue.

No. 3411-King White. Produces gigantic pure

No. 3413-Majestic Cream. Deep cream color.

No. 3421-Mrs. Tom Jones. Bright delphinium

No. 3409-Nubian. Deep chocolate,

No, 3417-Picture. Cream and pink.

No. 3412-Royal Purple, Large waved purple.

No. 3406-Royal Scot. Briliant scarle

No. 3418-Youth. Large white pink picotee edge.

No. 3422-New Mary Pickford - Dainty cream pink

No. 3404
\end{abstract}

\section{SUNNY SOUTH SWEET PEA} Collection No. 520

One full sized packet each of the 16 varieties of
Spencer Waved Sweet Peas as listed above,

Spencer Waved Sweet Pe

mailed postpaid or $\$ 1.00$.
No. 3350-Vadco Giant Spencer or Orchid-Flowering Mixilure of Sweet Peas

In offering our Giant Spencer and Orchid-flower ing Mixture of Sweet Peas, we are undoubtedly varieties obtainable. The varieties included in this Mixture will produce from three to four flowers on Grandiflora type previously used. Beautifully waved and fluted with long stems, varying from New Early-Flowering Spencers Bloom four weeks earlier than the late Spencers, and under congenial conditions flower continuously for four months. "Producing profusely, immense, stems. Price Early Flowering Varieties. Pkt. 10c; 2z. 40c; $1 / 4$ lb. $\$ 1.25$; lb. $\$ 4.00$. Spencer.
No. $3372-$ EARLY HEATHER BELL, A rich No. 3373-MEADOW LARK. Primrose yellow. purple.
No. $3375-E A R L Y$
YARRAWA. Splendid long stems and is most delicately tinted, the standard No. 3376 -TORCH. Salmon rose. SPENCERS. Mixed by ourselves from above Pkt. $10 ; 0 z, 40 \mathrm{c} ; 1 / 4$ lb. $\$ 1.25 ; 1 \mathrm{~b} . \$ 4.00$.

Old Fashioned Sweet Peas No. 3360 - GRANDIFLORA SWEET PEAS MIXED. Mixtures of Eckford's Grandiflora and the Unwin types is a studied formula containing proportions of various bright colors and shades.

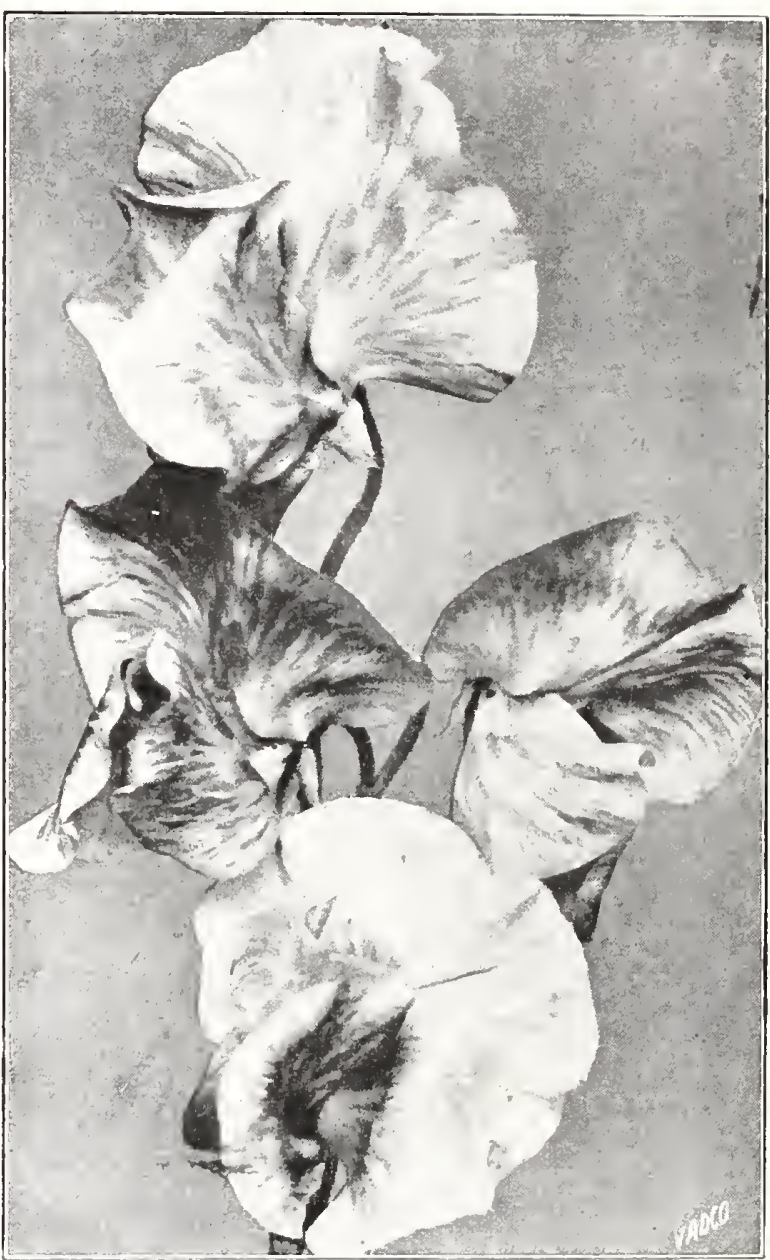

Giant Spencer or Orchid-Flowering Sweet Peas Mixed No. 3350

\begin{tabular}{|c|}
\hline INOCULATE THIS \\
SEED WITH \\
HUMOGERM \\
\hline
\end{tabular}

STIMUPLANT WONDER GÄRDEN

\section{VAN ANTWERP'S LARGE FLOWERING CANNAS}

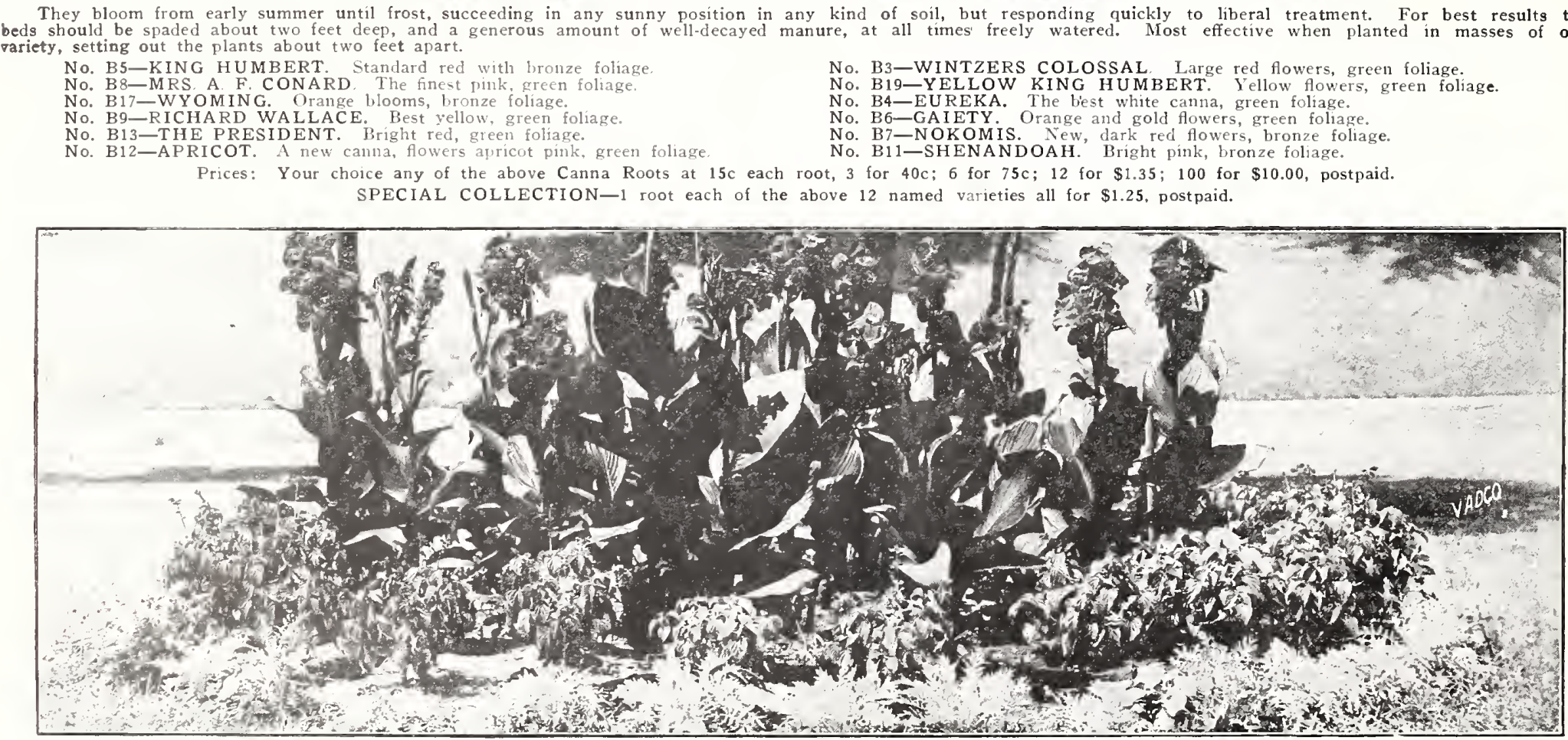




\section{VAN ANTWERP'S PRIZE GLADIOLUS}

\section{For Spring Planting}

Van Antwerp's Michigan grown Gladiolus Bulbs are far superior to cheap Southern grown bulbs. They
will produce immense spikes of blooms like the illustration on this page. Gladiolus or Sword Lilies as they are will produce immense spikes of blooms Every year Van Antwerp's sell thousands of these bulbs, and you will be delighted with these Michigan crown bulbs as they do better when brought here from the cold climate. 6 to 10 incbes apart according to the space you desire to cover.

*No. B27-America- Perhaps the most popular Gladiolus grown, immense flowers of ex. diamond dust. $7 \mathrm{c}$ each; 6 bulbs $35 \mathrm{c} ; 60 \mathrm{c}$ dozen; $\$ 4.00$ per 100 , postpaid.

No. B26-Alice Tiplady - A wonderful variety of an entirely new and distinct color the largest and finest of the Primulinus hybrids to date. $10 \mathrm{c}$ each; 6 for $50 \mathrm{c} ; \$ 1.00$ dozen; $\$ 7.00$ per 100, postpaid,

No. B40-Catherina_Lavender Blue. Heavy throat tongues of blood red. Wide blooms: $\$ 8.00$ for 100 , postpaid.

No. B31_-Baron Hulot_Full round flowers of rich velvet purple-violet, lighter in the trastingly effective. $10 \mathrm{c}$ each; 6 bulbs $40 \mathrm{c} ; 75 \mathrm{c}$ per dozen; $\$ 6.00$ per 100 , postpaid.

*No. B29-Empress of India_Rich dark maroon. 10c each: 6 bulbs 50c; $\$ 1.00$ *No. B33-Le Marechal Foch- Beautiful shade of light pink, flowers very large, dozen; $\$ 4.00$ per 100 , postpaid.

*No. B35-Wilbrink- Pale livid pink with creamy blotch on lower petal. Hower. $10 \mathrm{c}$ each; 6 bulbs $40 \mathrm{c}$; $75 \mathrm{c}$ per dozen; $\$ 5.00$ per 100 , postpaid. *No. B39-Mrs. Francis Ming-A most b'autiful and vivid pink; 18 long strong spike. Bc each; 6 bulbs 35c; $60 \mathrm{c}$ per dozen; $\$ 4.00$ per 100 , postpaid.

No. B41-Mrs. Frank Pendleton- Salmon pink, which extends to well as in the center, with a rich deep maroon blotch on the three lower petals, plowers are wide open and well placed on strong spikes. 8c each; 6 bulbs, $45 \mathrm{c} ; 80 \mathrm{c}$ per dozen:

No. B36-Orange Brilliant- $\begin{gathered}\text { An exquisite rich bilending. Wide blooms. } \\ 8 \mathrm{c} \text { each; } 6 \text { for } 45 \mathrm{c} ; 80 \mathrm{c} \text { per dozen; } \$ 6.00\end{gathered}$ per 100 , postpaid.

No. B28-1910 Rose_- A beautiful deep rose pink large spike. 8c each: *No. B42_L'Immaculee_— A favorite pure white for cutting; splendid No. B30-Evelyn Kirtland_- A splendid variety with large flowers of edges passing to shell-pink in the throat, with fiery scarlet blotches. $10 \mathrm{c}$ each; 6 for 50c; $\$ 1.00$ dozen; $\$ 7.00$ per 100 , postpaid,

*No. B32-Halley- 1 mmense flowers of bright orange-rose and having a $75 \mathrm{c}$ dozen; $\$ 6.00$ per 100 , postpaid.

*No. B44_Anna Eberius_ Violet Purple. One of the richest purple. Wonderful rich coloring. 8c each; 6 for $40 \mathrm{c} ; 75 \mathrm{c}$ dozen;
$\$ 6.00$ per 100 postpaid.

*No. B38_Louise_Richest Lavender. Large, wide blooms. Nothing more beautiful. 12c each; 6 for $70 \mathrm{c} ; \$ 1.25$ dozen; $\$ 8.00$ per 100, postpaid.

No. B34_Herada_- Very large flowers of pure mauve with No. B34 markings in the throat; on tall, straigbt spikes. An unusual color and very effective cut flower. 8c each; 6 for $40 \mathrm{c} ; 75 \mathrm{c}$ dozen; $\$ 6.00$ per 100 , postpaid.

No. B48-Panama-An improved America, largest and most notabl 6 bulbs $45 \mathrm{c}$; 80c per dozen. No. B43-Flora- Fine golden yellow; yery large flowers. $10 \mathrm{c}$ each; 6

No. B 6 6-War- A magnificent variety of rich ox-blood rad; shaded with \$8.00 per 100 , postpaid darkest crimson. 12c each; 6 for 70c; $\$ 1.25$ per dozen *No. B49-Niagara-Immense flowers of soft nankeen yellow, toned With bright lemon and overlaid with a slight rosy flush. 8c each; 6 for $40 \mathrm{c} ; 75 \mathrm{c}$ per dozen; $\$ 6.00$ per 100 .

No. B37-Prince of Wales-A large, tall . growing and sturdy variety with heavy 80c per dozen; \$6.00 per 100 .
*No. B45-Schwaben-D Pure canary-yellow, with a carmine blotch deep in the throat
Which aids in detracting from its uniformity in color. Flowers are wide open, large in size and well placed on strong spikes of medium height. 10c each; 6 bulbs * No. B47-Peace- Flowers are large, of good form, correctly placed on heavy straight each; 6 bulbs $40 \mathrm{c} ; 75 \mathrm{c}$ per dozen: $\$ 5.00$ per 100 . white, with lilac feathering on lower petals. 10 No. B50-Vadco Rainbow Mixture of Gladiolus- This famous mixture of deserves the name of rainbow. It is a well-blended combination of all the choice named varieties
and is far superior to the ordinary mixtures generally sold. (See illustration.) VADCO RAINBOW and is far superior to the ordinary mixtures generally sold. (See illustration.) VADCO RAINB
MIXTURE, 3 bulbs $15 \mathrm{c} ; 6$ bulbs $30 \mathrm{c} ; 50 \mathrm{c}$ per dozen; $\$ 3.50$ per 100; 1,000 for $\$ 30.00$, postpaid. 


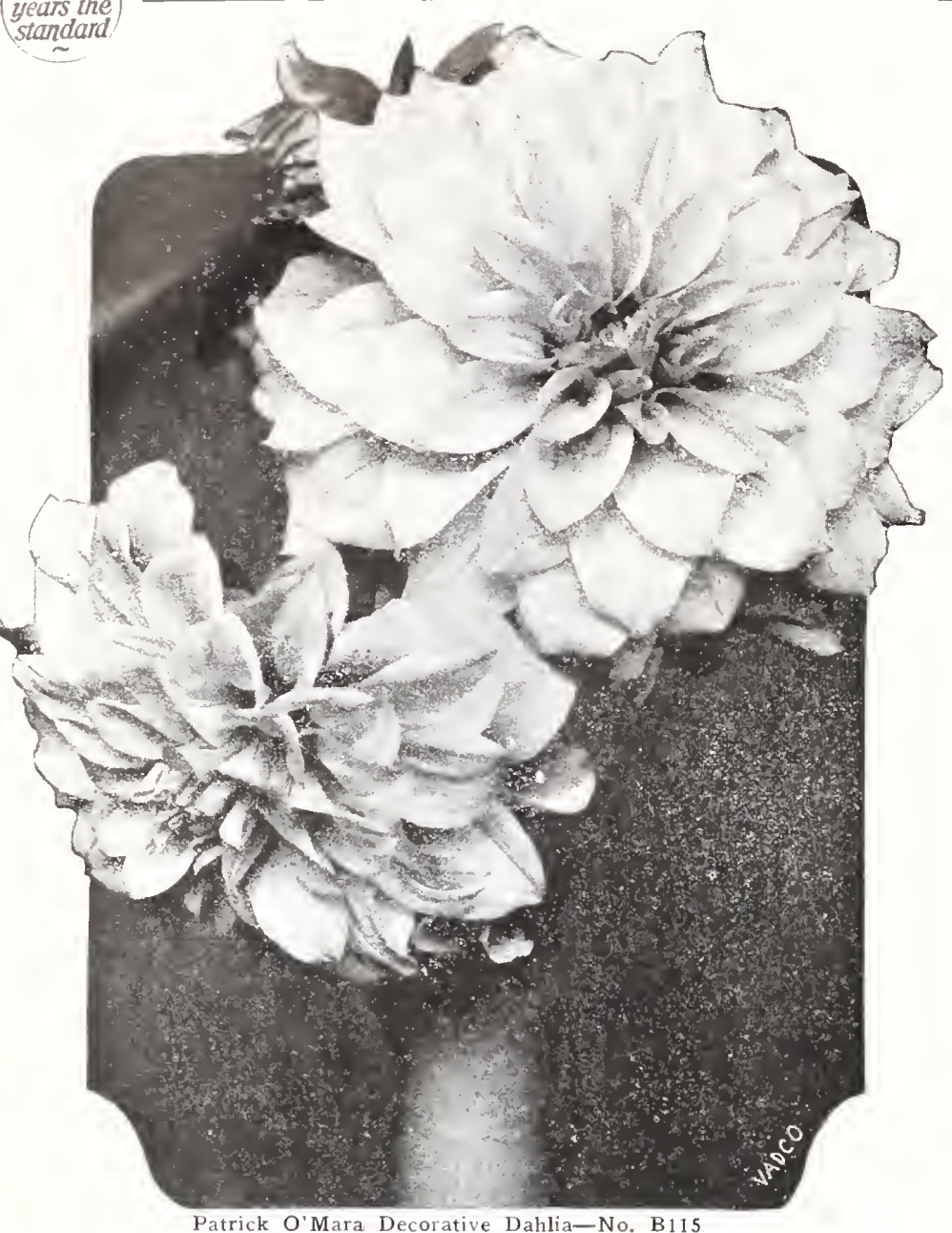

PEONY-FLOWERED DAHLIAS

No. B131-Bessie Seabury-

No. B132-Caecilia- Cirgantic creatmy

No. B134-Grace Kirschner-

No. B136-Latona-

No. B137-Mme. Van Bystein-

NEW AND RARE DAHLIAS

No. B141-Bonnie Brae-

No. B142-Elizabeth Slocombe

No. B143-Gloriana-

No. B144-Gladys Sherwood-

No. B145-Jane Selby-

No. B146-La Favoria-

No. B147-Mrs. Carl Selbach-

No. B148-Mrs. I. De Ver Warnerryy best Dah
S1, so each

No. B149-Pride of California- longe

No. B155-Snowdrift-

\section{SELECT CACTUS DAHLIAS}

No. B168-Bertram S. Varian-

No. B169-Bride's Bouquet-

No. B171 - Countess of Lonsdale- Deep salmon-red. 50c each

No. B172-Gen. J. B. Seth-Rich, brilliant

No. B173- J. Jackson -

No. B175-Libelle-Clear, Iteep, roserepuryle, 25c each; 3 for $60 \mathrm{c}$

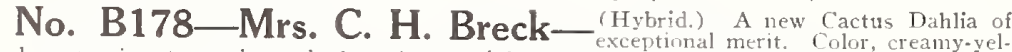

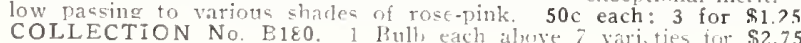

\section{Van Antwerp's Field Grown DAHLIA ROOTS}

who has Antwerp's Dahlia Roots are grown by the world's largest Dahlia grower

Culture-Dahlias thrive best in a sunny location. Work the soil to a depth of 1 st to May 15th plant the bulbs, about 6 inches deep, laid flat with the eye up with soil (for each bulb) and fill to the level with soil. Top dress periodically during to have plants stand 2 feet apart in less which are 3 feet apart.

ezing

\section{SUPERB DECORATIVE DAHLIAS}

No. B101-Easton- Not cxtra large, lut a vartety of liriliant color No. B102-Frank A. Walker-

No. B103-Jack Rose— The identical shade of the rose with the same No. B104-Le Grand Manitou— The color of this superber pariety

No. B105-Melody—Cle

No. B106-Mina Burgle- $A$

No. B109-Minos— The color is intense velvety maroon, almost black.

No. B112-Ora Dow- is beautiful velvety maroo

No. B113-Patrick O'Mara— Cield Medal by American Dahlia So

No. B114-Queention, $75 \mathrm{c}$ each; 3 for $\$ 2.00$.

No. B115-Sylvia—Whitc edgecl pink. 20c each; 3 for 50 c

COLLECTION No B116, Bulh ach above 11 varietics for $\$ 3.50$.

\section{CHOICE SHOW DAHLIAS}

No. B118-A. D. Livoni- ${ }_{3}^{\text {aplenti }}$ for 60 c

No. B119-Maude Adams— Prure snowy white overlaid with a clear

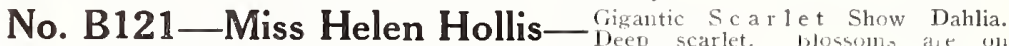

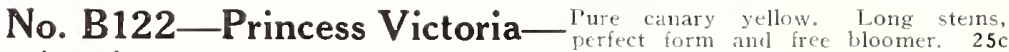

No. B123-Red Hussar-

No. B126-Vivian— 1 fine wlite effectively edged rose-violet. $25 \mathrm{c}$ each

No. B127-Yellow Duke- ${ }_{3}$ for $\$ 1.00$.

COLLECTION No. B130. 1 Bulb each above 7 varietices for 81.85 .

\section{FINE SINGLE DAHLIAS}

No. B161-Aubright Beauty— Immense snow-white flowers, 250 No. B162-Crimson Century— Deep liowing crimson, shaded dark $25 \mathrm{c}$ each; 3 for $\$ 1.00$.

No. B163-Rose-Pink Century- $\underset{\text { eachear }}{\text { A rose-pink color. 25c }}$ No. B164-St. George- ${ }_{3}^{A}$ very free-fowering clear yellow, 25c each COLLECTTON No. B160. 1 Bulh each of the 4 varicties of Single Dahlias, The 4

\section{FANCY-LEAVED CALADIUMS B220}

No other summer foliage plant equals the Fancy Caladiums in rich and the furnishing of the conservatory during the summer months for window boxes, or even for outdoor bedding in shady or semi-shady positions. Wined colors. Prices: $25 \mathrm{e}$ each; $1 / 2$ doz., $\$ 1.25 ;$ doz., $\$ 2.50$, postpaid.

\section{CALADIUM ESCULENTUM}

Elephant's Ear - Grand, tropical-looking rlant. A favorite for specigroups. They produce enormous leaves, frequently 4 teet long by 3 feet wide;

No. B235-EXTRA SIZE CALADIUM BULBS No. B236-FIRST SIZE CALADIUM Bil in BULBS7 to 9 inches in circumference. Price, $20 \mathrm{c}$ each; $\$ 2.00$ per dozen. 


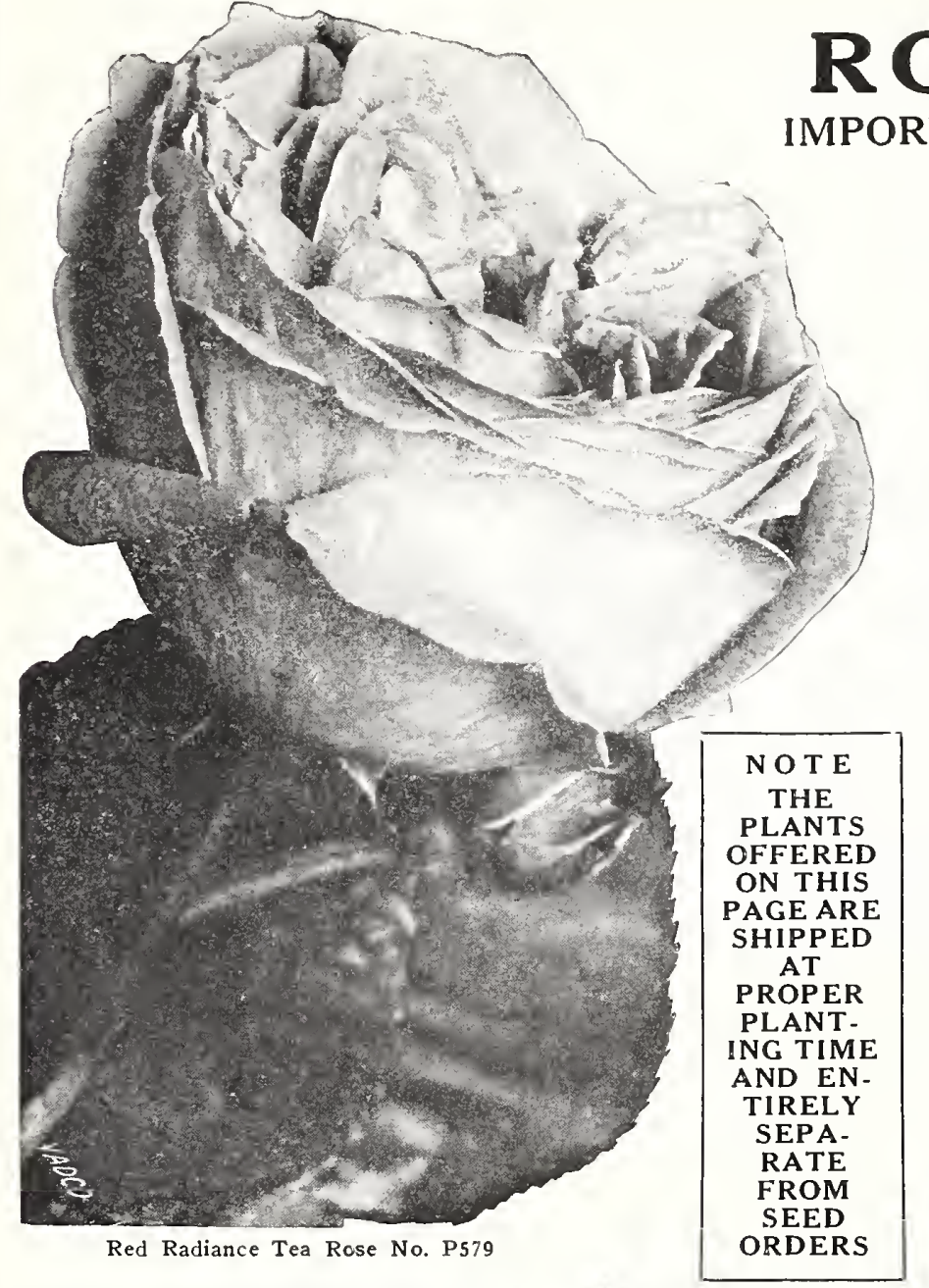

GERANIUM PLANTS

No. P501-Alphonse Ricard- vermillion; large flowers and enorNo. P503-Beaute Poitevine— Beautiful shade of shrimp-pink, grad. No. P505-Jean Viaud- This is the best large-flowering double pink richest deep pink, shading near the base of the petals to light pinks. we wave the No. P507-La Favorite- In this double white variety that hase ever No. P509-Madame Landryvariety produces enormous trusses, No. P511-S. A. Nutt- This, the finest of dark crimson Geraniums. nium, being used in the largest parks and public grounds of the country in preference to all others. Any of the above varieties of Geraniums for $35 \mathrm{c}$ each. Collection F E R N S

Every house ought to have one or more of these splendid decorative plants for the porches in summer of

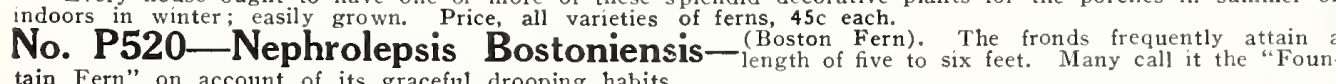
tain Fern" on account of its graceful drooping habits. (Nephrolepsis Goodii) This is the most delicate of all
No. P523-Baby's Breath Fern-l lace ferns. It really looks like filigree work. In many respects it is a far better and more ornamental variety than any of the others.

No. P525-Whitmani-Beautiful ostrich plume type fern and one of the prettiest.

No. P527-McCawii-For window or table decoration this one will be found to be the best.

No. P529-Asparagus Plumosus Nanus- (Lace Fern). Grown for its delicate lace-like Nulture. (See illustration.)
No. P531 -Asparagus Sprengeri - Also called Emerald Feather, A magnificent porch or
basket plant in the South. The fronds or leaves grow 4 to 5 feet long. Hundreds of magnificent plants of this are seen every summer on the porches. postpaid.

No. B201_-Tuberoses Double Dwarf Pearl_ $\begin{gathered}\text { The strain we offer is greatly im } \\ \text { proved, the }\end{gathered}$ size, very double waxy white, and deliciously fragrant. $8 \mathrm{c}$ each; 3 for $20 \mathrm{c}$; $75 \mathrm{c}$ per dozen; $\$ 5.00$ per
100 , postpaid. No. B81-Cinnamon Vine Rootsflowers. Grow from 15 to 30 feet high the first season and will attain a much greater length when fully
established. Extra-large roots. $15 \mathrm{c}$ each; $\$ 1.50$ per dozen, postpaid. No. B82-Maideira Vine Roots-growth and freedom from insects. Thick, glossy leaves, and long, hanging stems of feattery, r ragrante
white flowers, The tubers we offer are selected large size. Price, $15 \mathrm{ceach}$; $\$ 1.50$ per dozen, postpaid. No. B131-Amaryllis Johnsoni Bulbs—"St. Joseph Lily." the strong stems. The color is a fine crims.
petal. Large bulls. 40c each; 6 for $\$ 2.25$.

\section{EVERBLOOMING HYBRID TEA ROSES}

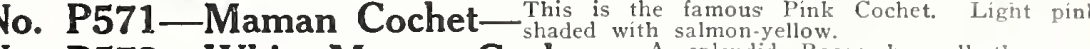

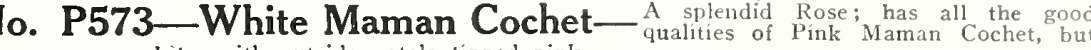
No. P575-Alexander Hill Gray- Deep lemon-yellow, similar in color to No. P577-Gruss An Teplitz— Bright crimson, white, fiery red center; cup. No. P579-Red Radiance - Cllear red without a trace of other color. Se o. P581_Jonkheer J. L. MockPrice: Healthy field grown roots of any of the above Roses for $\$ 1.00$ each root. $\$ 10.00$

\section{CLIMBING ROSES}

No. P585-Dorothy Perkins-(H. W.) Deep rose; very sweet-scented.

o. P587-Excelsa or Red Dorothy Perkins_- son-scarlet. $_{\text {(H. W }}$ Intense crim

589-Climbing American Beauty-(H. Cl.) Rich red.

-White Dorothy Perkins- A pure white sport from Dorothy

Price: Climbing Roses 85 c each root. $\$ 7.50$ per dozen. 1 each of the 5 varieties for

\section{CHRYSANTHEMUM PLANTS}

No. P551-Silver Wedding— Of White . A pure glistening white chrysanthemum hardy, prolific in bloom and in all a splendid variety. of extra large size. We have offered this superb variety before and it has always No. P555-Chieftain- (Pink). The most popular of all pinks; the is a selected strain, and good in every way. Buds in September; blooms in No. P557-Golden Queen- (Yellow). This is the finest and most Any of the above 4 varieties, $25 \mathrm{c}$ each; $\$ 2.50$ per dozen

\section{No. P563 AZALEA PLANTS}

\section{Climate They hardy shrub is particularly well adapted to our Southern soil roduces such a charming effect as the Azalea. \\ We can supply the following separate varieties: Pink, White, Salmon and Red}

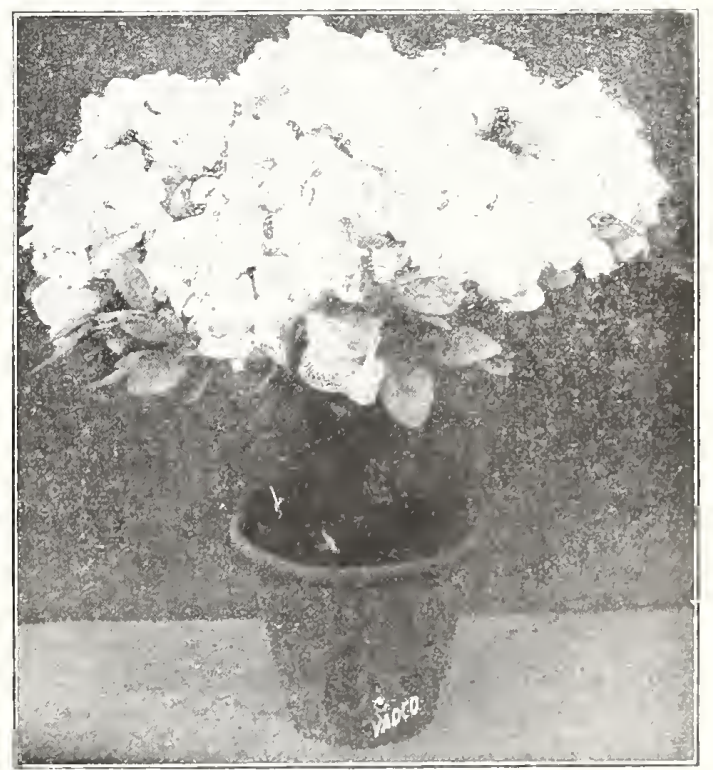

White Azalea Plant. We can supply these beautiful plants in Pink, Salmon, Red, and White; 9 to 11 inch
$\$ 1.75$ each: 12 to 14 inches high. $\$ 2.50$ each. 


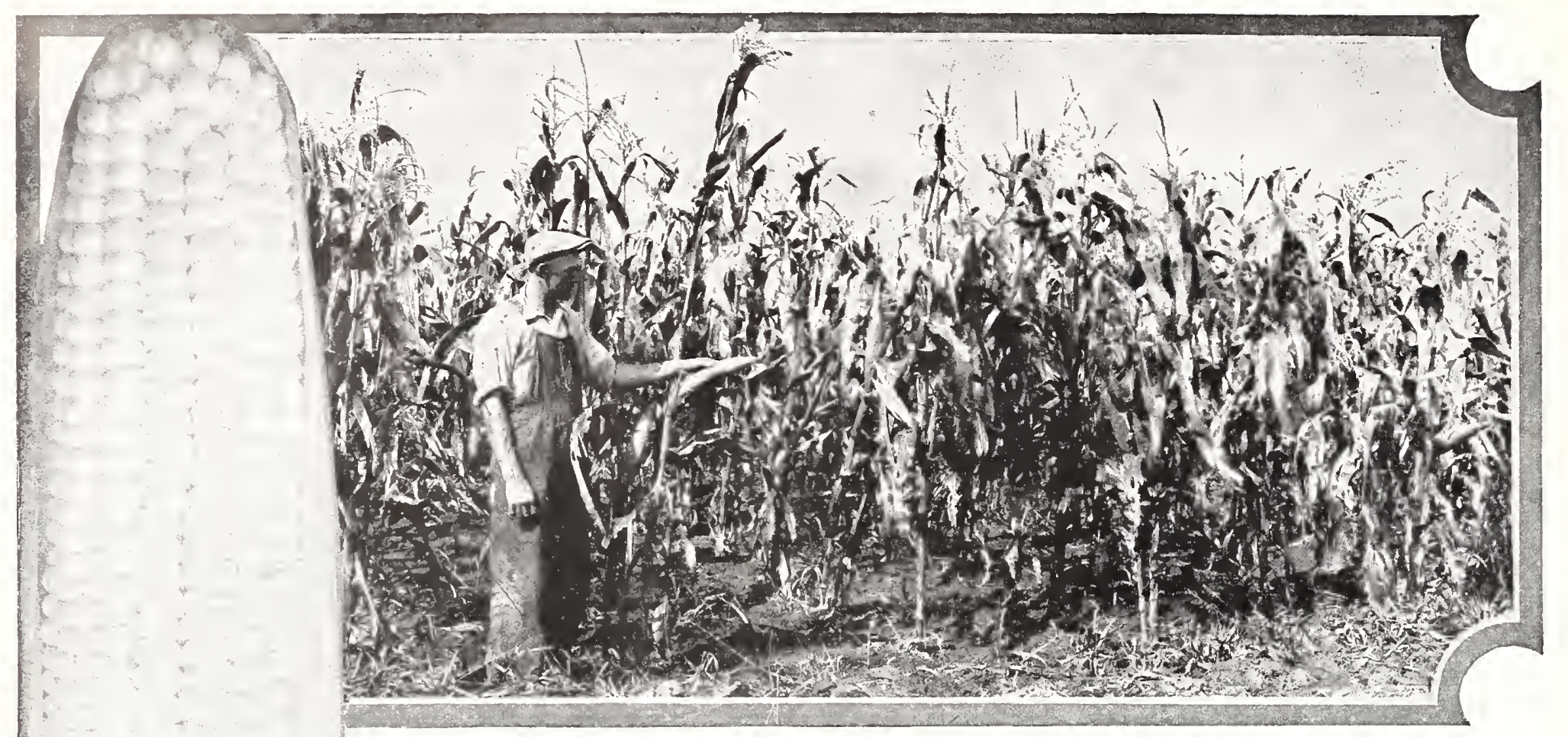

\section{SELECTED SEED CORN}

\section{8-Vadco Truckers' Favorite}

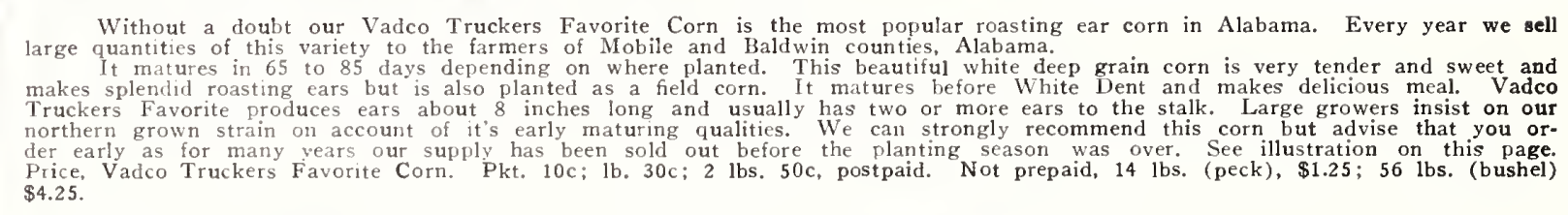

\section{No. F 13 -Van Antwerp's Paymaster Corn} The Finest of All the Red Cob Corns

No. F. 15-Champion Early White Dent

The Largest Early White Corn in the World

It is an Early Wbite Dent coming in almost as early as the Adams Early, but much larger; sample ears have been shown us. 14 inches in length and $31 / 2$ inches in diameter. For stock feeding it is very valuable; coming as it does, at a time whes Again, it is a corn that has made itself hefore the hot. dry weather and when other to varieties must make their growth. Champion Early White Dent is a safe crop Champion will make enormous yields, and on thin land it adapts itself to hard conditions, and will come nearer to making a crop than any other corn you can $\$ 1.00 ; 56$ lbs. (bushel) $\$ 3.25$.

No. F6-Surecropper

Surecropper is a very quick maturing corn and is largely planted in the South Surecropper is a heavy yielder some white grain variety and also a white cob. The ears are not quite as large as snme

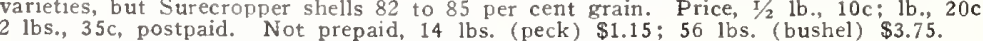

No. F2-Yellow Flint Havana

Produces small ears and grain, and is one of the hardiest of all flint corns. It
will grow and yield under all kinds of adverse conditions and withstands weevil better than other varieties of corn. Price: $\mathrm{I} / 2 \mathrm{lb} .10 \mathrm{c} ; 1 \mathrm{~b} .20 \mathrm{c} ; 2 \mathrm{lbs}$. 35c, postpaid. Not
prepaid, $14 \mathrm{lbs}$. (peck) $\$ 1.00 ; 56 \mathrm{lbs}$. (bushel) $\$ 3.50$.

No. F5-Improved Early Leaming A standard yellow corn for general field purposes in the South. It is usually
planted for green feed and ensilage. Price, I/ $1 \mathrm{~b}, 10 \mathrm{c} ; 1 \mathrm{~b}$. 20c; $2 \mathrm{lbs}$. 35c, postpaid. planted for green feed and ensilage. Price, I/ lb. 10c; lb. 20c; 2 lbs. 35c, postpaid.
Not prepaid, 14 lbs. (peck) 80c; 56 lbs. (bushel) $\$ 2.75$.

\section{No.F9-Large Golden Yellow Dent Corn}

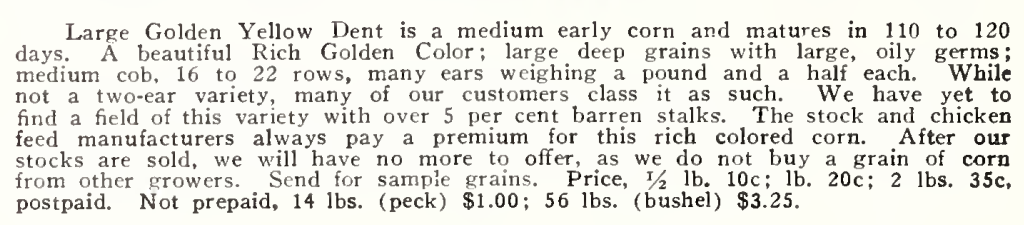

No. F 1 -Hastings' Prolific

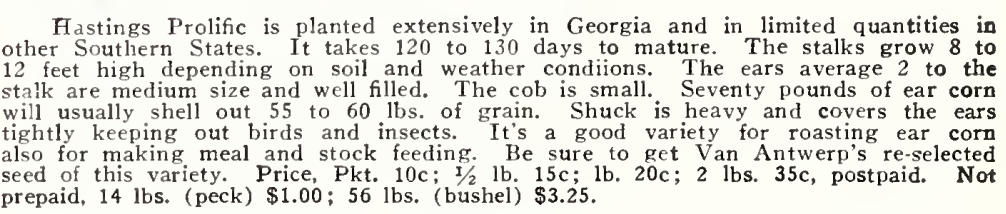

No. F4-White Flint (Florida Flint)

A splendid variety for general purposes. It has long, deep, white, flinty graihs, small cob. A fine keeper and as weevil-proof as it is possible to get a white corn.
Price, $1 / 2 \mathrm{lb}$. 10c: 1b. 20c; 2 lbs. 35c, postpaid. Not prepaid, 14 lbs. (peck) $\$ 1.00$; $56 \mathrm{lbs}$. (bushel) $\$ 3.50$. 


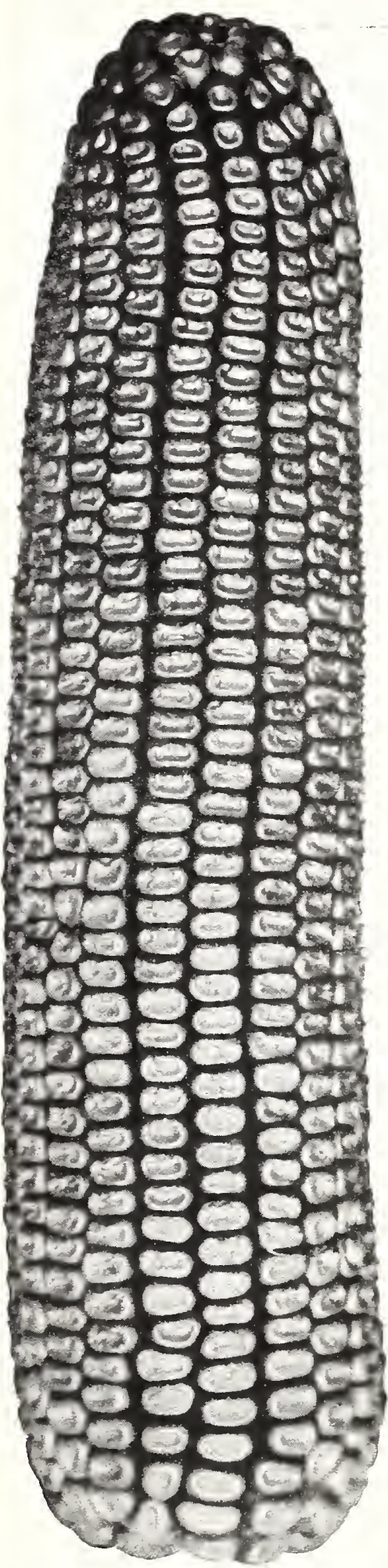

Ear of Van Antwerp's Large Golden Yellow Dent Corn No. F

\section{SELECTED SEED CORN (Continued)}

No. F3_-Hickory King._. The grain is so wide and deep and the cob so small that often a single grain will cover the upon depended Not prepaid, $14 \mathrm{lbs}$. (peck) $\$ 1.00 ; 56 \mathrm{lbs}$. (bushel) $\$ 3.25$

No. F19-Silver Mine, lowa Grown-The type of this corn is very even and uniform; ears run from 9 to 12 medium white cob; ears well filled out at butt end and tip end, latures in 100 days Price, I/2 lb. 15c; lb. 25c; 2 lbs. 35c, postpaid. Not prepaid, 14 lbs. (peck) $\$ 1.00 ; 56$ lbs. (bushel) $\$ 3.25$.

No. F55-Gold Mine, Iowa Grown- The same as Silver Mine, only the kernels are golden yellon, Price, $\$ 1.00,56$ lbs. (bushel) $\$ 3.25$

No. F11 - Early White Snowflake Corn_ This corn is largely planted for milling and feeding purposes. Ears (pocks) $\$ 1.00 ; 56$ lbs. (bushel) $\$ 3.50$.

No. F14-New Mammoth White June Corn- Our strain of Niammoth White June Corn is vastly superior of the worst type. The Mammoth White June Corn is a beautiful snowflake white, soft and of fine texture. Ears average eight

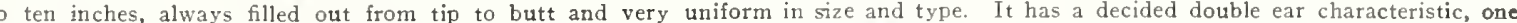
for its fine Not prepaid, 14 lbs. (peck) \$1.00; 56 lbs. (bushel) $\$ 3.50$

No. F7-Mexican June Corn-We can supply Mexican June Conto Therior in every way to Yexican June, in fact in recent years it has token the place Not prepaid, 14 lbs. (peck) $\$ 1.00$; 56 lbs. (bushel) $\$ 3.50$.

Eureka Ensilage_Eureka is a doub!e purpose corn, for aside from being a first-class ensilage corn, as a field variety it Price, lb. 25c; 2 lbs. 40c, postpaid. Not prepaid, $14 \mathrm{lbs}$. (peck) $\$ 1.00 ; 56 \mathrm{lbs}$. (bushel) $\$ 4.00$

\section{STOCK BEETS or MANGELS}

No. 171-Mammoth Long Red- ${ }_{\text {with }}^{\text {No other mangel }}$ can variety in yield. Compare of forty to fifty tons per acre have been made on good land and under thorough cultivation. The roots often weigh twenty to twenty-five pounds each. It grows well above ground, is easily pulled; the deep red roots are straight,
solid. Price: Oz. 10c; 1 $1 / 4 \mathrm{lb}$. 25c; $1 \mathrm{~b}$. $75 \mathrm{c} ; 5 \mathrm{lbs}$. $\$ 3.00$, postpaid.

No. 175-Golden Tankard_- Especially recommended for the dairyproperties and the richer quality of the milk. The flesh is firm and solid, rich, $\$ 4.00$ postpaid.

\section{SUGAR CROWDER PEAS}

Van Antwerp's Best 3 Varieties

The crowder pea is gaining popularity as a table pea in man sections of the South; in fact it's taking the place of the Englis cow pea, making bushy upight plants which need no support. The peas are very close together in the pod and are slightly flattened at the sides as the pods contain as many as twenty perfect peas. The being extremely sweet makes them an ideal table pea. We offer the

No. F99-White Sugar Crowder.

No. F102-Cream Sugar Crowder.

Price: Any above varieties of Sugar Crowder Peas, pkt., 10c; $1 / 2 \mathrm{lb}$ 20c; lb. 35c; 2 lbs. 60c; 5 lbs., $\$ 1.25$, postpaid. Not prepaid, 10 lbs. over at $15 \mathrm{c}$ per $1 \mathrm{~b}$; ; $60 \mathrm{lbs}$, (bushel) $\$ 8.00$.

\section{BEFORE PLANTING CORN DISINFECT WITH SEMESAN JR.}

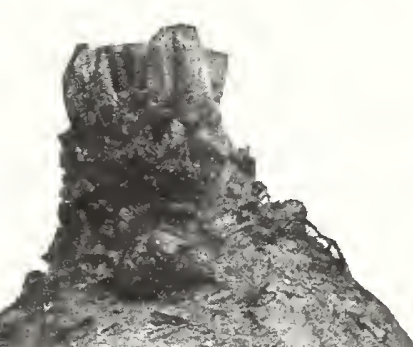




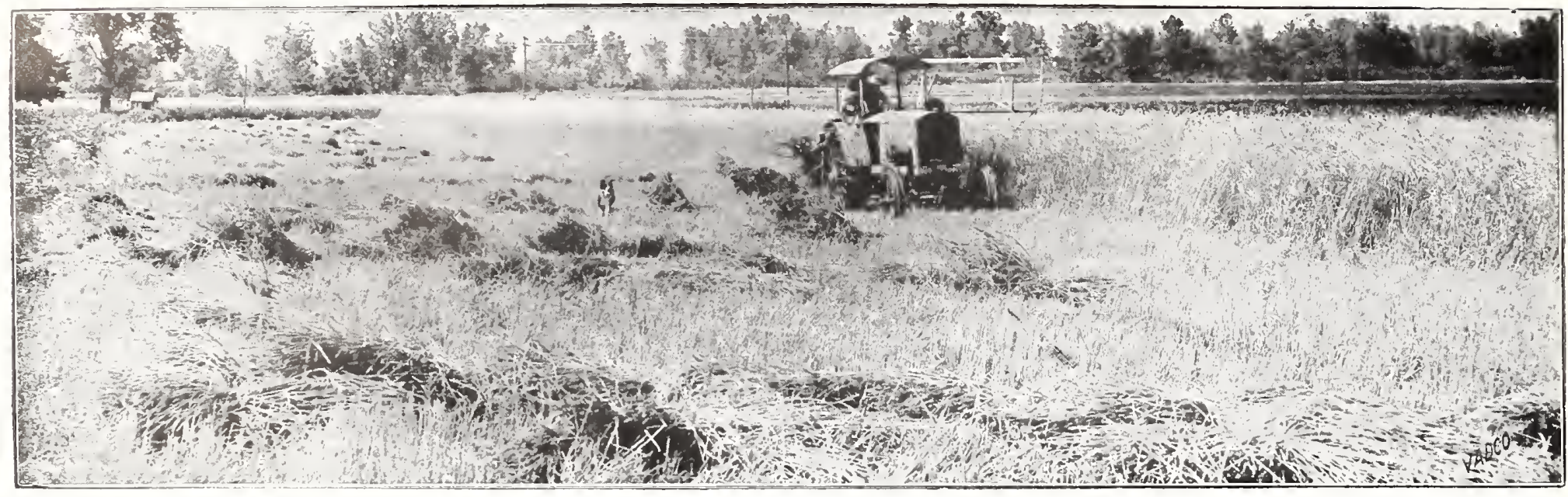

\section{VAN ANTWERP'S FIELD and FARM SEEDS}

No. F179-Cleveland Big Boll Cotton-

opens

is stron boll

No. F178-A New Cotton-Delfos 6102-

at
Fos
had
is
earl
pro
pro
tho
neers
torn
tra
rim
lim
It is one of the earliest and most rapidly maturing varieties known. Price: Lb. 20c,
3 lbs. $50 \mathrm{c}$, postpaid. Not prepaid, $7 \mathrm{I} / 2 \mathrm{lbs}$. (peck) $60 \mathrm{c}, 30 \mathrm{lbs}$. (bushel) $\$ 2.00$.

No. F177-Simpkin's Prolific Cotton-A medium size boll turing variety that is well adapted to boll weevil sections. very prosilifc, quick mamuch in growth and shape. It grows a strong, hardy plant, limbs ont close to the 3 rows and plants spaced 18 to 24 inches apart in boll wecvil sections. Yrice. Lb. 20c:

No. F183-Improved Early King Cotton- $\begin{gathered}\text { In sections whero } \\ \text { thc holl weevil is }\end{gathered}$ prevalent or wliere the season is short, an early maturing cotton is absolutely neces-
sary, even regardless of the size of the boll or length of lint. The Improved King will make its crop as early as any small and mcdium boll cotton. Price: Lb. 20c;
$3 \mathrm{lbs}$. 50c; postpaid. Not prepaid, $71 / 2$ lbs. (peck) $60 \mathrm{c} ; 30 \mathrm{lbs}$. (bushel) $\$ 2.00$.

No. F185-Bank Account Cotton- It opens earlier than other blow out or drop out as quickly. It's a heavier bearer, and makes better ind longer lint. It roots deeply, resisting both drouth and storms. It branches well and has
light, open foliage, letting in the sun to all parts of the plant. Price: Lb. 20c: 3 lbe. $50 \mathrm{c}$, postpaid. Not prepaid, $7 \mathrm{r} / 2 \mathrm{lbs}$. (peck) $60 \mathrm{c} ; 30 \mathrm{lbs}$. (bushel) $\$ 2.00$.

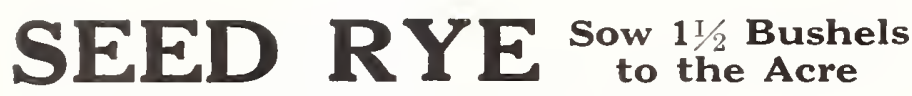

\begin{abstract}
It will increase the milk flow of the best-fed dairy stock.
It will increase the milk flow of the best-fed dairy stock.
It furnishes green food earlier in the spring than other grains.

Grazing it during

It is an excellent winter crop to conserve
It improves the condition of the soil when
It is harder than wheat, and can be sown
It can be
\end{abstract}

No. F111-Abruzzi Rye-

rye. Best rye known for grazing, cover crop or seed purposes. Comes much earlier
than

made by other ryes. In big demand for grazing and for fall and winter cover crop.

Should make 25 to 30 bushels of seed per acre. Has made 25 bushels. Price, 1b. $20 \mathrm{c}$;
2 lbs. $35 \mathrm{c}$, postpaid. Not prepaid, 14 lbs. (peck) \$1.15; 56 lbs. (bushel) $\$ 3.75$.

No. F109-Southern Grown- Re men gres a splendid cover crop, and

suited, makes heavy grain head on thick stiff straw about 5 feet high. It is fine

for grazing, although the spring growth is not as early as Abruzzi. Price, $1 \mathrm{~b}$.
2 lbs. $35 \mathrm{c}$, postpaid. Not prepaid, 14 lbs. (peck) $\$ 1.00 ; 56$ lbs. (bushel) $\$ 3.00$.

\section{VETCH}

Our Southern farmer should give this plant more attention. The feed value of Vetch hay is very high, being equal, pound for pound, with wheat bran; so from this it is easy to realize its feed value. The question of suitable soil for Vetch is less important than with most crops. It grows anywhere the Cow Pea thrives, on
thin, sandy lands, unproductive to Cow Peas, on lime lands, where Cow Peas do not produce good crops of seed. It is seeded in combination with other grains like Oats, Wheat, etc. If Vetch is sown by itself, not less than thirty pounds should be used in seeding an acre; where sown with other grains, about half this amount will
answer. Vetch is one of the best leguminous plants for renovating and enriching

No. F251-Hairy or Sand Vetch—- This is the hardiest of all the the severest winters. We have never known it to be winter killed if an early stand March the vines cover the ground. It does especially well on sandy soils, but can
be grown on any well-drained land. It is wonderfully drought resistant, making good crops in dry seasons when other kinds fail completely. Price, lb. 30c; 2 lbs.

\section{WHY BUY GRAIN AND FODDER?--GROW YOUR OWN}

\section{No. F255-Egyptian Wheat or Shallu-} splendid feed for chickens. It is a variety of the sorghum family, with large, loose,
bushy heads, covered thickly with small grains. If left standing, the grains drop
off in a scattering manner and the chickens gather it. For this reason, some folks

feet

$10 \mathrm{lbs}$. or over at $10 \mathrm{c} \mathrm{cb}$; ; $100 \mathrm{lbs}$. $\$ 8.00$.

No. F233-Buckwheat- Grown both for the four and for poultry which it is excellent. We have found that the Japancse variety is preferable, being cast in May to I luly per acre. Price : Lb. 20c; 2 lbs. 35c; postpaid. Not prepaid, 12
lbs. (peck) $\$ 1.15 ; 48$ bs. (bushel) $\$ 4.00$. No. F229-Upland Rice- There is big money in growing Upland The opland sort is very much like and stored the same as Oats or Wheat Price: Lb. 20c; 2 ibs. 35 c, postpaid. No. F21-White Kaffir Corn- This varicty grwws from ${ }^{4}$ to 8 growth. It has a strong stem with enormous wide teaves. The stalks scep green and are brittle, making excellent fodder, either green or dried, which is highly relished
No. F23-Red Kaffir Corn- The stalks are more slender and more long and slender, and measure from 12 to 18 inches in length. The seeds are red. No. F237-Sunflower-Mammoth Russian- Plant and you would corn, though it may be planted much earlier, as the seed is not injured by slight ireezing of the ground.
thoroughly ripe to avoid scattering and loss of seed, but should be carefully dried before storage to prevent molding. Plant in any waste space during the early spring up to middle of July, sowing at the rate of 8 to 10 pounds to the acre.
Lb. 20c; 2 lbs. 35c, postpaid. Not prepaid, 10 lbs. or over at $12 \mathrm{c}$ per $1 \mathrm{~b}$.

No. F259-Feterita- Feterita is an Egyptian forage plant and similar to and grows taller. It matures a month earlier than Kaffir Corn or Milo Maze. Feterita succeeds in the dryest and hottest seasons making a crop when sorghum

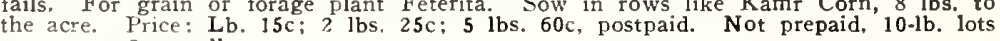
No. F239-Teosinte- ${ }_{\text {tinuous cut cung forage crop. }}^{A}$ we strongly recorm mend this to be generally sown as it will furnish a continuous daily supply of most in May or J J une at the rate of 2 to 3 pounds to the acre, in drills $3 \% / 2$ to 4 feet apart. in May or June at the rate of 2 to 3 pounds to the acre, in drills $3 y_{2}$ to 4 reet apart
Price: Lb. 30c; 2 lbs. 55 c, postpaid. Not prepaid, 10-1b. lots or over at $16 \mathrm{c}$ per $1 \mathrm{~b}$. 


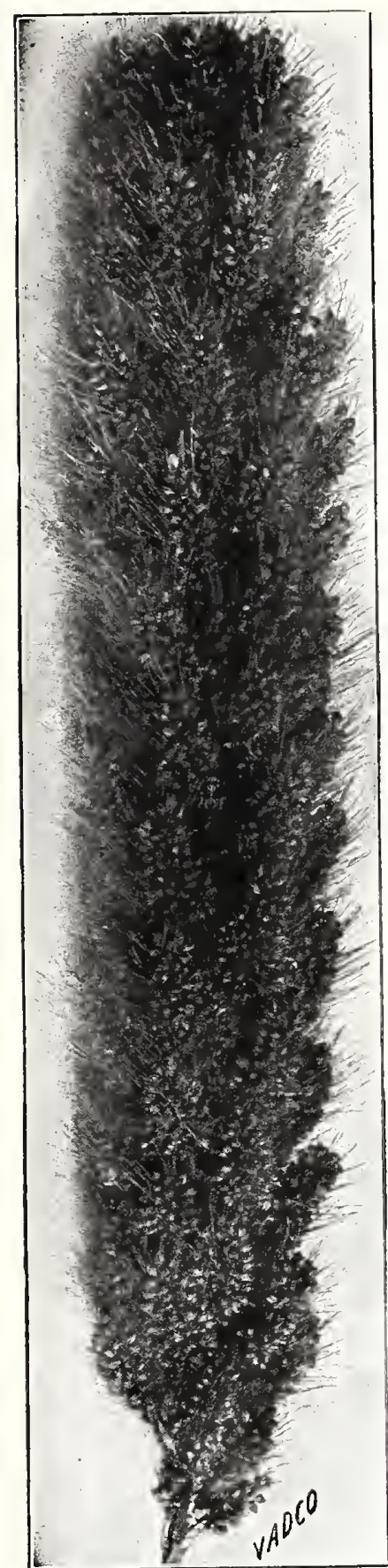

Tennessee Golden Millet No. F159

TENNESSEE GOLDEN MILLET A A REE To have the finest millet hay sow thickly, not less than a bushel to the acre, from the middle of May till the end of July. Thin or German Millet makes a quickly grown, easily cured and large yielding, nutritious hay crop. It comes so quickly that it can be sown after wheat is cut, and leaves the land clean and in fine mechanical mistake to suppose that it is particularly exhaustive to the land. It is' exhaustive if allowed to stand till the seeds form, but millet should be cut when coming into flower, as after that stage the woody fibre forms in the stem and the hay is hard and unpalatable. Cut at the proper time, it makes a splendid hay. As a summer catch crop it has

Growing millet with an early variety of cow-peas like Whippoorwill is becoming quite popular, three pecks of millet being sown
with a bushel of cow-peas. See illustration.

No. F159-Tennessee Grown Golden Millet— Price, 1 b. $30 \mathrm{~s} ; 2$ ibs. $50 \mathrm{cc}$, postpaid. Not prepaid,

No. F163-Pearl, or Cat-Tail Millet- Produces as much as 100 tons of green forage per acre. It will grow 10 to of 3 to 4 feet, when it will stool out enormously, and make rapid growth can be cut in this way three or four times in a season
It is largely used by dairymen and others who have cattle for furnshing them with green feed through the summer, as if a sufficient quantity is sown, it can be cut as desired, furnishing a daily supply of green feed until killed by freezing. It can be fed either green or cured as dry forage, making a most nutritious feed, which is relished by all kinds of stock. Sow thinly in rows 3 feet apart
at the rate of 8 to 10 pounds to the acre. Price, lb. 25 c; 5 lbs. 80 c, postpaid. Not prepaid, $12 \frac{12}{2}$ lbs. (peck) $\$ 1.50 ; 50$ lbs. (bushel) $\$ 5.50$

\section{SELECTED COWPEAS}

Peas make one of the largest yielding and most nutritiou Cow Peas make one of the largest yielding and most nutritious of vines to improve the soil, it being much more economical to cut off the crops of vines and cure them as hay or forage crop; then turn under the roots and stubble, thus enriching the soil.

No. F87-Brabham- The Brabham Pea is rapidly where. The seeds are similar in appearance to Whippoorwill, but smaller, and do not require to be seeded as thickly as other kinds. Price, 1b. 20c; 2 lbs, $35 \mathrm{c}$, postpaid. Not prepaid, 15 lbs. (peck) No. F89-Large Black-Eye_ The mo os t popular grown of all the Black-Eye varieties. The peas are larger, the are always in demand, both green and dried. Price, lb., 25c; 2 lbs.
$40 \mathrm{c}$, postpaid. Not prepaid, $15 \mathrm{lbs}$. (peck) $\$ 1.50 ; 60$ lbs. (bushel) $40 \mathrm{c}$, postpaid. Not prepaid, $15 \mathrm{lbs}$. (peck) $\$ 1.50 ; 60$ lbs. (bushel)
$\$ 5.00$. No. F91-Iron- Has proven to be disease and drought early to mature; will retain its leaves and foliage better and for sowing at the North. Seeds small. Price, lb. $20 ; 2$ lbs. $35 \mathrm{c}$,
postpaid Not prepaid, 15 lbs. peck $\$ 1.10 ; 56$ lbs. (bushel) $\$ 3.75$. No. F93-Whippoorwill—A Aavorite bunching sort. easy to gather on account of bush babit. Price, $1 \mathrm{~b}$. 20c; 2 lbs. $35 \mathrm{c}$;
postpaid. Not prepaid, 15 lbs. (oeck) $\$ 1.10 ; 60$ lbs. (bushel) $\$ 3.75$. No. F97_Gallavant, or Lady_- Peas are $\begin{gathered}\text { very } \\ \text { small } \\ \text { in } \\ \text { size, }\end{gathered}$ but are of a fine, rich flavor; a most superior taole Pea. The most desirable of all varieties to grow for home use. Known
many as the Lady Pea. Price, 1b. 30c; 2 lbs. 50c, postpaid.

No. F96-Mixed Cowpeas- Most planters prefer because they grow off better and thicker, making a better crop of
vines and forage than single varieties alone. For soil improving purposes there is a real advantage in planting mixed Cowpeas. 15 lbs. (peck) $85 \mathrm{c} ; 60$ lbs. (bushel) $\$ 3.00$.

No. F95_Clay-Quite a favorite with many; has a clay-colored Price, lb. 20c; 2 lbs. 35c, postpaid. Not prepai 15 lbs. (peck) $\$ 1.00 ; 60$ lbs. (bushel) $\$ 3.50$

\section{VELVET BEANS}

\section{No. F189-Bush Velvet Beans- Recommended}

No. F189-Bush Velvet Beans- ${ }_{\text {ing }}$ in orchards or in cornfields where a heavy growth is desired for 15 to 18 incbes apart is claimed to produce nearly as much forage as the vining varieties. It is about three week
later than the 100 -day bean. See illustration. Price, $1 \mathrm{lb}$. 20c; 2 lb. 35c, postpaid. Not prepaid, 15 lbs. (peck) No. 193-Extra Early Speckle Velvet Beans- An extra early Velvet Bean that is largely tremely popular. It is one of the quickest-growing and earliest maturing of the Velvet Beans and is wel adapted for growing in districts further North than Velvet Beans ordinarily have been grown. You can plant postpaid. Not prepaid, 15 lbs. (peck) $90 \mathrm{c}$; $60 \mathrm{lbs}$. (bushel) $\$ 3.00 ; 2$ bushels, $\$ 5.50$

No. F195-Osceola Velvet Beans- The Osceola has given excellent results as a forage crop. the Early Speckled or 100-Day, with pods larger and farther advanced in the same length of time. It also has the advantage of being free from the
$\$ 1.00 ; 60$ lbs. (bushel) $\$ 3.50$.

\section{No. F197-MUNG BEANS \\ The Greatest of All Soil Builders}

Mung Beans were introduced into this country about seven years ago from India and China. They have than Soy Beans, Cow Peas or Velvet Beans and they succeed in the dryest weather and under conditions that any of the other legume crops fail. The Alabama Experimental Station found Mung Beans were not bothered by ing to the soil where which often destroys other legume crops. Mung Beans grow the finest kind of hay which any stock will eat up clean. They should be planted during the months of May, June and July; the later plantings make a smaller plant but heavier seeder. Sow at the rate of 3 to 5 lbs. to an acre in $31 / 2$ foot rows or to foll grain. Van Antwerp's Mung Beans are re-cleaned and the finest seed you can get in the South. We sold thousands of pounds of them last year and our customers were delighted with the results. Be sure to

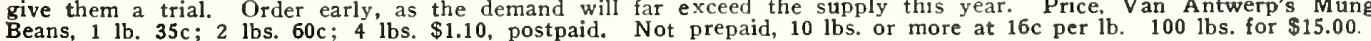

\section{SOY BEANS}

ULTURE. Soy beans may be planted either broadcast or in
Usually a better crop is had when planted in drills and condition for the following crop. They grow equally well on When sown broadcast sow No. F139-Laredo- The Laredo Soy Bean is a medium a large number of fine stems, though unlike the O-Too-Tan

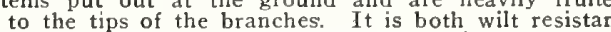
Laredo

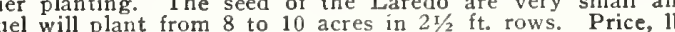
o. F133-Otootan- Few soy beans can equal OtooNo. F135-Biloxi- An upright variety growing 4 to 5 No. F131-Mammoth Yellow_The latest, yet Frown for both beans and forage, both of which it yields

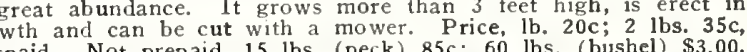

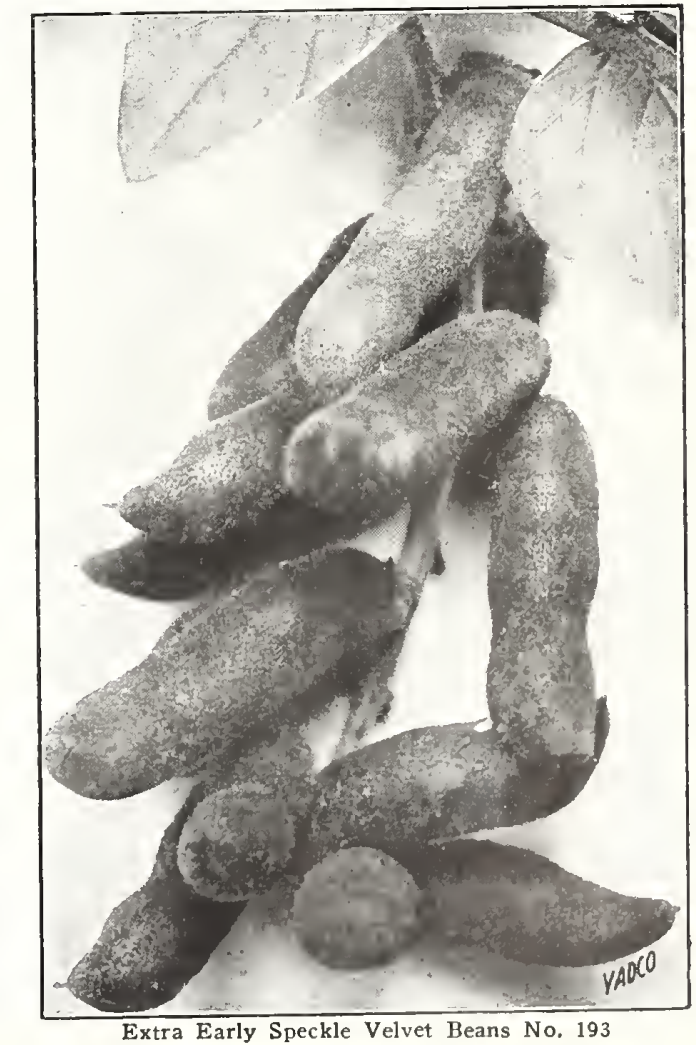




\section{CLOVER and GRASS SEEDS \\ BEST T1ME AND METHOD OF SEEDING}

The Red, Mammoth, Alsike and Crimson Clovers are also quite largely sown at the last working cuttings the following season and the chances for securing stands of Clover when sown at this time are found by experience to be fully equal to sowing at any other time.

Japan Clover is adapted only for Spring and Summer seeding and should not be sown before the middle of March, as it requires warm weather to germinate satisfactorily. The best months for seeding Alf

No. F43-Sudan Grass-

season allowed four cuttings. The quality of the hay is good, anal

No. F44 Johnson Grass-

cultivated fields there

is a great dema
The seed may

Not prepaid, $10 \mathrm{lb}$. lots or over at $12 \mathrm{c}$ per lb.; $100 \mathrm{lbs}$. $10 \mathrm{c}$ per $\mathrm{lb}$,

No. F65-Alsike or Swedish Clover- A valuable perennial Clover, growth of

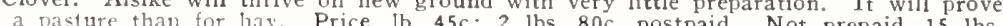
(peck) $\$ 5.00 ; 60$ lbs. (bushel) $\$ 18.00$.

No. F59-Medium Red Clover-

5 lbs. $\$ 2.50 ; 10$ ibs. $\$ 4.50 ; 25$ lbs. $\$ 10.50 ; 100$ lbs. $\$ 40.00$.

No. F67-White Blossom Sweet Clover (Mellilotus Alba)_

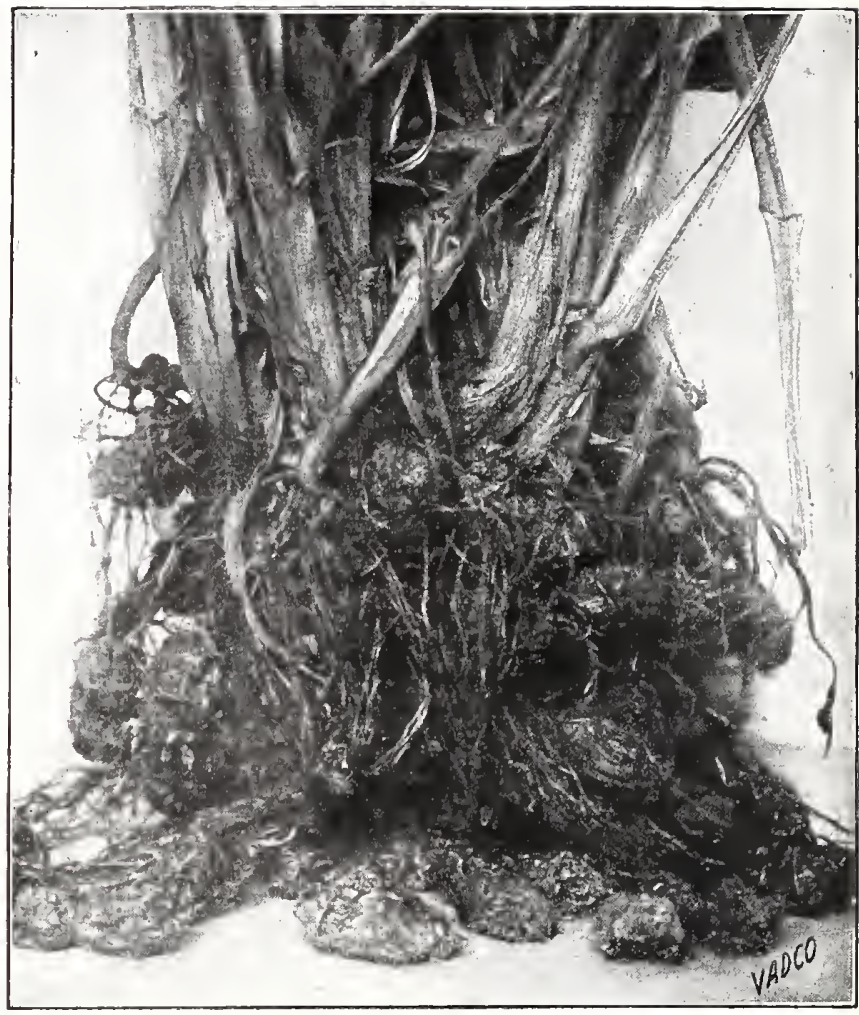

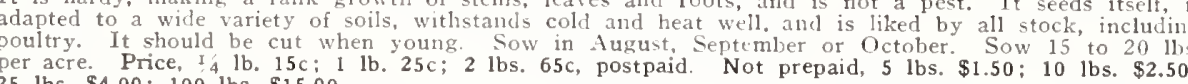

No. F69-Yellow Blossom Sweet Clover (Mellilotus Indica) -

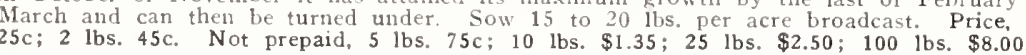

No. F71-Japan Clover or Lespedeza-A

summer, when other things have died out. Sow 20 to 25 pounds to the acre in the fall of year with
grain or grasses. Price, lb. 30c; 2 lbs. 50c; 5 lbs. $\$ 1.00$, postpaid. Not prepaid, 25 lbs. $\$ 4.00 ; 100$

No. F57_-White Clover, Fancy- A small, creeping perennial, used for pasturage

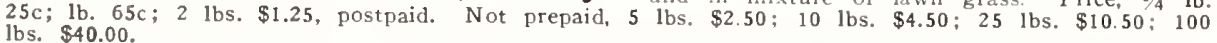

No. F79_Alfalfa, or Lucerne, Kansas Grown-

Chufas or Earth Almonds No. F241

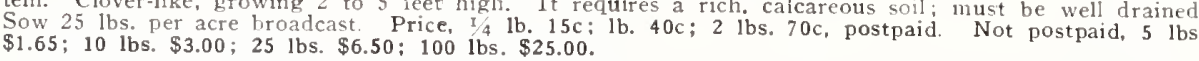

No. F61-Crimson Clover-

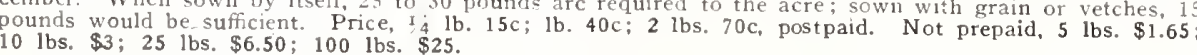

No. F63-Bur Clover-

the rate of 20 to 25 tbs. of hulled, recleaned seed to the acre bro bro
ths. per acre Price, Hulled and Recleaned. Seed: $1 / 4$ Ib $15 \mathrm{c} ; \mathrm{lb} .30 \mathrm{c} ; 2$ lbs. $55 \mathrm{c}$, postpaid. Not prepaid, $5 \mathrm{lbs}$.
$10 \mathrm{lbs} . \$ 2.25 ; 25$ lbs. $\$ 5 ; 100$ lbs. $\$ 18$. (If wanted in

No. F49-Timothy_ For bay, timothy is the best grown of all grasses. Price. lb. 20c; 2 lbs. $35 \mathrm{c}$, postpaid. Not

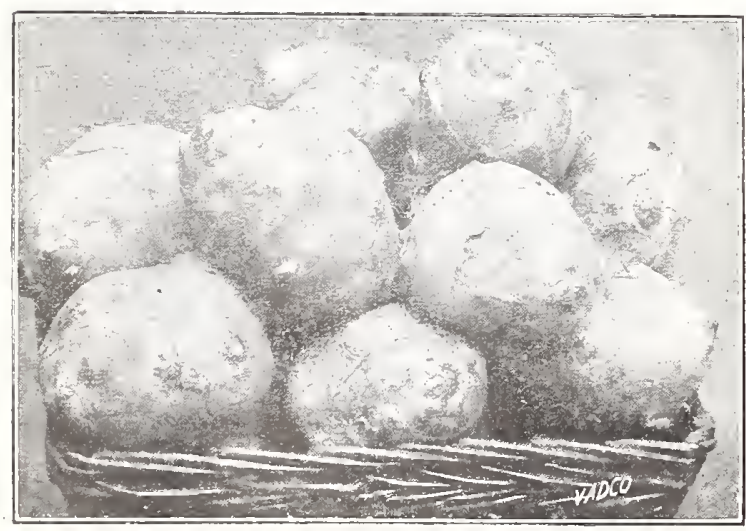

No. F39-Orchard Grass_- Orchard grass is a very vigorous grower and yields large crops

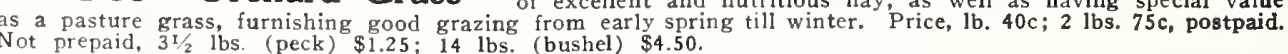

No. F 35-English Rye Grass-This grass is becoming more and mote appreciated as a remains bright and green throughout the season, will bear frequent and close cropping, is relished by all
kinds of stock, and is not easily injured by tramping. It prefers a stiff wet soil, but does well on any soil that is 110 to try. Price, $1 \mathrm{~b} .40 \mathrm{c} ; 2$ lbs. 75 c, postpaid. Not prepaid, 6 lbs. (peck) \$1.50; 24 lbs. (bushel)

No. F37-Italian Rye Grass- Yields three or four cuttings a year of most nutritious hay;

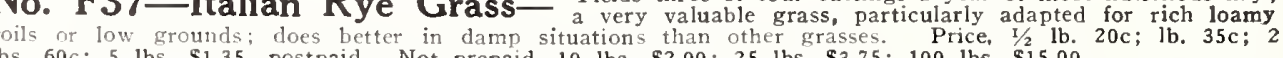
bs. 60 ; 5 lbs. $\$ 1.35$, postpaid. Not prepaid, 10 lbs. $\$ 2.00 ; 25$ lbs. $\$ 3.75 ; 100$ lbs. $\$ 15.00$

No. F33-Fancy Kentucky Blue Grass- A good pasture grass, forming a fine sward. oil, makes a very good lawn, but not as fine as our regular lawn grass. Price, lb. 50c; 2 lbs. 90c, postNo. F47-Red Top or Herd's Grass- Hay and pasture grass. Succeeds on most kinds stiff soils. By repeated mowing, this grass holds well during the summer, but its' chief value is for winter pastures. It is perennial, not doing so well the first year but gets better the longer it grows Price

\section{No. F253-Jerusalem, or Ground Artichokes}

Fattens bogs have never been known to have cholera. Only a small quantity of seed is required to plant an acre. Three or four bushels per acre are sufficient. The tubers should be cut into small pieces and not more
than two of these should be put in a hill. The hills may be from 2 to 4 feet apart. Plant during than two of these should be put in a hill. The hills may be from 2 to 4 feet apart. Plant during
March and April. (See jillustration). Price, lb. 25c; 3 lbs. 70c; postpaid; 10 lb. lots or over $8 \mathrm{c}$ lb. 


\section{No. F223 -DWARF ESSEX RAPE \\ For Sheep, Hogs, Cattle and Poultry}

Sow it as early as possible-late March or early April is not too late.

CULTURE-Sow as early as the land can be made ready, the earlier the better, but sowings as late as April have been very successful. Sow either broadcast or in drills 18 inches to 2 feet apart; when grown in drills and cultivated occasionally, the leaves will cover the intervening space;

growth. good for providing pasture for all kinds of stock. It has been estimated to yield more than 10 tons of green forage per acre, that for fattening is claimed to be worth, pound for pound, double
the value of clover. One of the State experiment stations reports that the lowest average gain on lambs fed on rape alone was 7 to $8 \mathrm{lbs}$. per month.

\section{PEANUTS}

Any soil that will grow corn or cotton will grow peanuts; on light sandy or loamy soils there are few crops more profitable. In

No. F208_Tennessee Red Peanuts_- A variety that satisfies anyone who outh and yet larger in size, with a greater number of nuts or kernels than in most sorts planted in the South. A most productive and desirable variety. Pods are large close and well filled, containing 3 to 4 nuts or kernels with red skins in each pod. Of very mild, sweet, enjoyable
flavor. Price, 1b. $25 \mathrm{c} ; 4$ lbs. $75 \mathrm{c}$, postpaid. Not prepaid, 10-lb. lots or over at $11 \mathrm{c} \mathrm{lb}$. No. F209-Spanish Peanuts_ Although not as large as the other kinds, there is can compare with it in sweetness and flavor. There is also a marked freedom from pops, so ibs. $75 \mathrm{c}$, postpaid. Not prepaid, $10-1 \mathrm{~b}$. lots or over at $11 \mathrm{c}$ lb.

No. F207_-Valencia Peanuts_ The Valencia fills the demand for a peanut that common varieties. It is splendidly adapted for growing an containing more nuts than the common varieties. It is splendidly adapted for growing on the light sandy soils of the South
Atlantic Seaboard. Price: Lb. $25 \mathrm{c} ; 4 \mathrm{lbs}$. $75 \mathrm{c}$, postpaid. Not prepaid, 10-1b. lots or over at 12c.

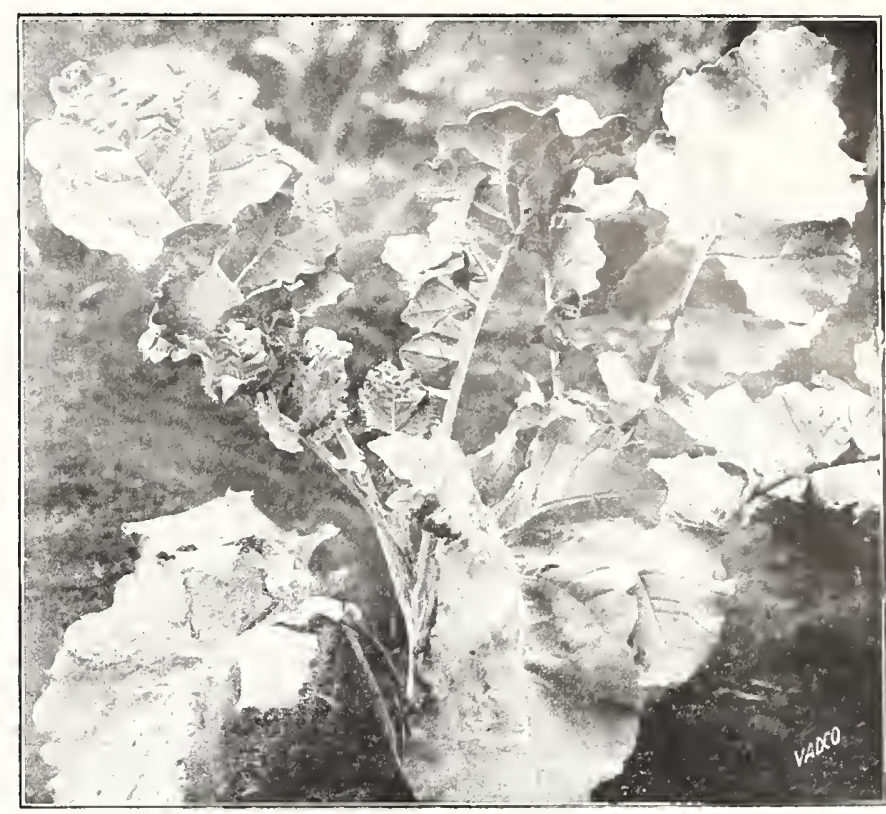

Our true European grown Dwarf Essex Rape No. F223

\section{SPECIAL NOTICE---Read it before you buy field seeds}

\section{All field seed prices quoted in this catalog are subject to market changes. We want you to write us before planting} for "SPECIAL QUOTATION" on field seeds. This catalog is printed in December and prices may be lower by February or March, so write us before you buy - we may save you money. We are anxious that you plant the highest quality seeds obtainable. Don't fail to drop us a line or use the back of one of the pink ORDER BLANKS to ask us for prices or questions. Remember, Van Antwerp's Seeds have satisfied southern planters for over 50 years and are still the south's best seeds.

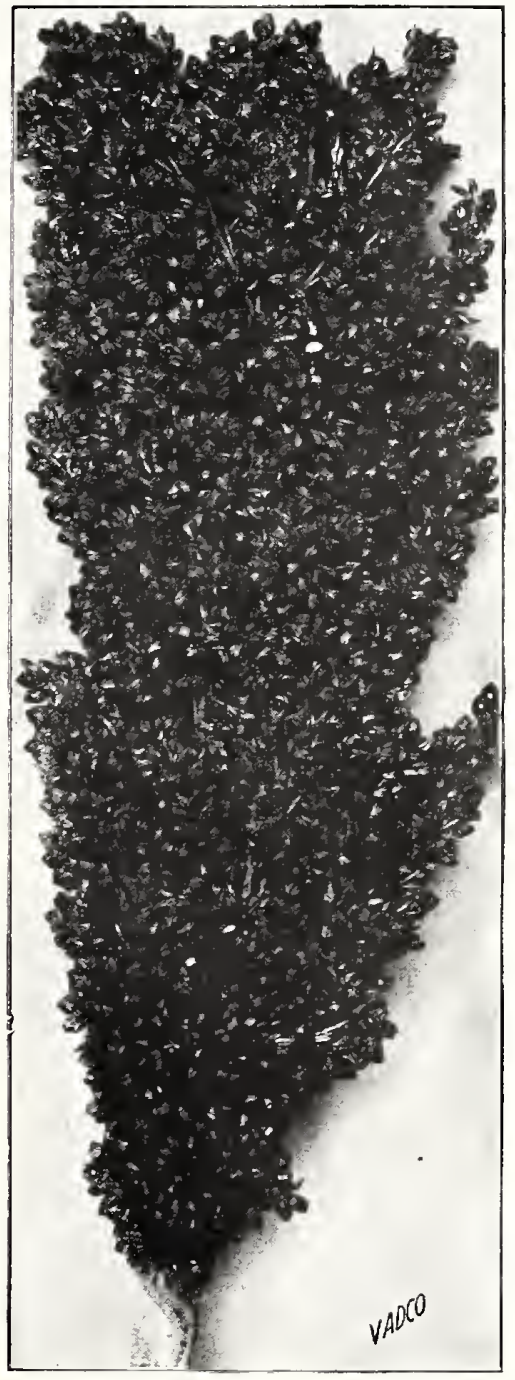

Texas Seeded Ribbon Cane No. F175

\section{Sorghum and Sugar Cane}

No. F175-Texas Seeded Ribbon CaneIt makes syrup of a bright amber color and fine flavor. The
syrup yield is good, frequently from 175 to 200 gallons to the acre. As it grows 10 to 12 feet tall, with an abundance o fodder, it makes a most economical ensilage, filling the silo ground has become thoroughly warm, thin out to stand 10 to 12 inchcs apart in the rows, and cultivate just as you do corn (peck) $90 \mathrm{c} ; 50 \mathrm{lbs}$. (bushel) $\$ 3.00$.

No. F167-Early Amber Caneghums and furnishes a large yield of most nutritious forage which may be fed eitber green or cured. If planted early it will yield two cuttings a season, stooling out thicker each tim

\section{OATS}

The oat is a cool season plant and requires early planting. Oats will produce well on poorer soils than other grains, but poor soils should have an application of 200 to 300 pounds acid phosphate per acre. This has been found profitable, whereas the ute

No. F157-Burt, or Ninety-Day OatsIt makes a good growth of straw, is an abundant yielder of bright, clean, heavy grain, is free from rust, and what is of equal importance when plantings' are late, it is of early ma turity Early plantings can be cut in time to put the sam land in corn, peanuts, cowpeas, millet or other summer crops. soils of the coast sections of the South Atlantic States, where the results have been uniformly good. The grains somewbat
resemble the Red Rust-Proof, except that it is a little lighter in color. Price, $4 \mathrm{lbs}$. (1/2 peck) $35 \mathrm{c}$; 8 lbs. (peck) $65 \mathrm{c}$, postpaid. Not prepaid, 32 lbs. (bushel) $\$ 1.25$.

No. F256-Citrus Trifoliata Seed-Wild Orange Seed. This is the seed of the Wild Orange and is planted Or. Our seed stock of Citrus Trifoliata is inspected by the state inspector and is certified seed. We take every care to keep this

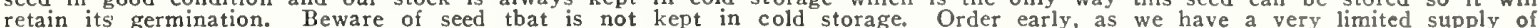
Price $1 \mathrm{lb}$. (about 2,200 seeds) $\$ 1.25 ; 2 \mathrm{lbs}$. $\$ 2.25 ; 5 \mathrm{lb}$. lots or over at $\$ 1.00$ per $1 \mathrm{~b}$.

No. F258-Beggarweed-Beggarweed is grown principally in Florida and the Gulf States. It is a natural plant (n) for the next year. Sow at the beginning of the summer. Price, $1 / 2$ 1b. 40c; lb. 70c; 2 lbs. \$1.25, postpaid. Not prepaid, 10 Raffia - Raffia is used in budding, grafting and in Nursery and garden work. Natural Raffia. Price, 1b. 40c; 3 lbs. 


\title{
THE SOUTH'S FINEST LAWNS Are Produced By Sowing Van Antwerp's Grass Seed
}

\section{How to Make a Lawn}

\begin{abstract}
For new or remade lawns, spade or plow twelve incbes deep, removing all stones or litter. Apply fifty pounds of hydrated air slacked lime to every thousand square feet and harrow or rake in. About ten days after liming apply one hundred pounds Wizard Brand Pulverized Sheep Manure to every thousand square feet. Avoid using or seed sower, using care to cover the entire surface and rake or barrow in the seed. When the seed is raked in roll the surface with an iron roller or for a small lawn the ground can be eveled with the back of a spade. The lawn should be carefull watched and all weeds pulled up or cut witt a knife as they appear from time to time. Keep the lawn well watered during dry weather, using a garden hose with a revolving sprinkler is the best method. An occasional top dressing of pulverized sheep manure will keep the lawn green during the ho
summer months.
\end{abstract}

For Summer Lawns

Sow during the months of February, March and April Van Antwerp's Summer

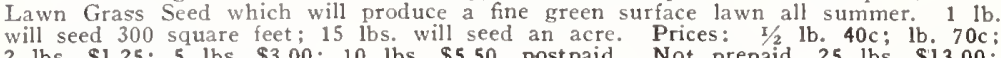
100 lbs. $\$ 50.00$. No. F41-Bermuda Grass- Bermuda, Carpet or Van Antwerp' grasses that will grow and make a satisfactory lawn during the hot summe months in the South. Bermuda Grass seed can be sown over winter lawns and raked in without digging up the winter lawn. Van Antwerps acre. 1116 will sow

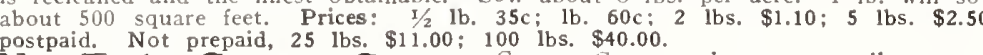
No. F45-Carpet Grass- Carpet Grass makes an excellent sum ter it grows. It is also used for golf courses as it stands lieavy trampling. It will grow on sandy soil and spreads rapidly. Carpet Grass is used as a pasture grass also. For additional information about this grass write to the Department

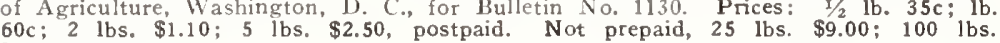

\section{For Winter Lawns}

Sow Van Antwerp's Winter Lawn Grass Seed from September till end of January. This grass has been used in the South for many years with very satis.

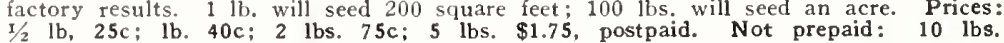
$\$ 2.75 ; 25$ lbs. $\$ 6.50 ; 100$ lbs. $\$ 25$.

No. F37_-Italian Rye Grass_- This grass is used extensively for in all sections of the South We recommend this grass for winter lawns, and by sowing on Bermuda sod you can have a beautiful lawn all the year round. Sow 1 lb. seed to every 300 square feet or about 200 lbs. to an acre. Prices: $1 / 2$ lb. $\$ 4.00 ; 100$ lbs. $\$ 15.00$

No. F39-Orchard Grass_-Orchard grass is a very vigorous grower nutritious hay, as well as having special value as a pasture grass, furnishing good grazing. Many prefer orchard green lawn all winter. Sow 16 . to every 300 square feet, or about 30 lbs. per

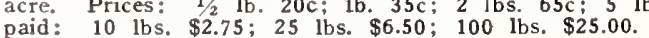

\section{FERTILIZERS FOR FARM, GARDEN AND LAW|N

\section{WIZARD SHEEP MANURE}

\section{ADCO} \\ GARDEN LIME}

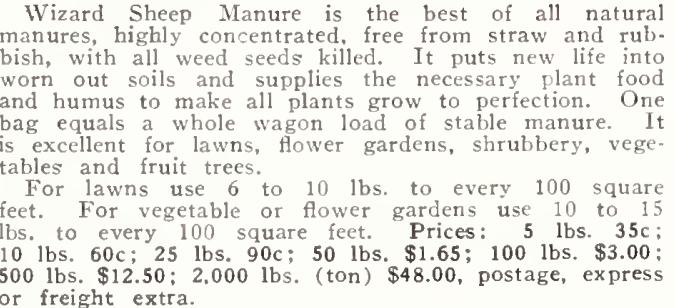

POULTRY MANURE

Processed Poultry Manure is one of the safest an most reliable forms of plant food that can be applied and tender vegetation if used in reasonable amounts. For vegetables, lawns or flowers it will be found very
valuable. Prices: 5 lbs. $35 \mathrm{c}$ : 10 lbs. 60c; $25 \mathrm{lbs}$. (ton) $\$ 48.00$. Postage, express or freight extra.

\section{BONE MEAL}

A splendid fertilizer for every soil; supplies abundant nourishment to plants over a long period. Excellent for top-dressing lawns and pasture-lands.

Quantity required: For trees and vines, 2 to 4 quart each; for top-dressing, 1,000 to 1,500 lbs. per acre rose beds and plants, 1 part to about 50 of soil ; for starting a new lawn, as a base, 3 to 5 lbs. per 100 Prices: 5 lbs, 25c; 10 lbs. 50c; 25 lbs. 90c; 100 (ton) $\$ 55.00$

\section{NITRATE OF SODA}

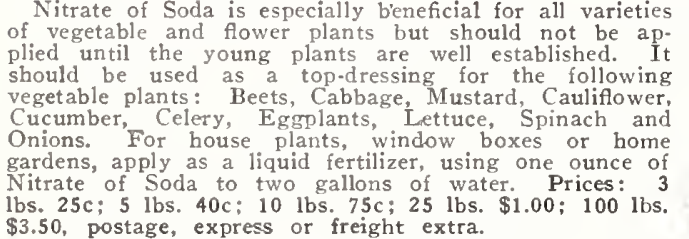

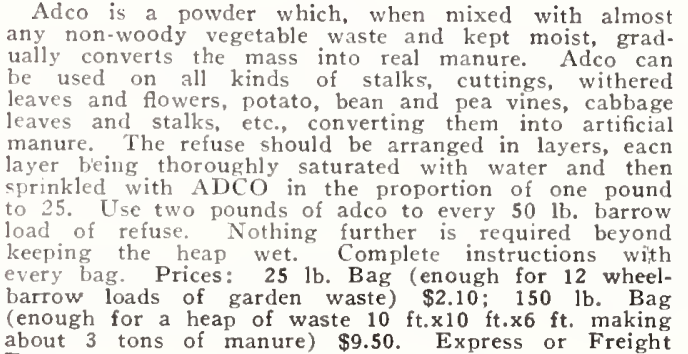

about 3 . making

\section{COTTON SEED MEAL}

A splendid fertilizer for all kinds of plants and es pecially recommended for Azaleas. Prices: 5 lbs. $25 \mathrm{c}$;
$10 \mathrm{lbs}$. 50c; 25 lbs. $90 \mathrm{c} ; 50 \mathrm{lbs} . \$ 1.75 ; 100 \mathrm{lbs}$. $\$ 3.00$. Postage, Express or Freight Extra.

\section{SULPHATE OF POTASH}

Prices: 5 lbs. 25c; 10 lbs. 50c; 25 lbs. $\$ 1.00$; 50 lhs $\$ 1.85 ; 100$ lbs. $\$ 3.50$, postage, express or freight

\section{MURIATE OF POTASH}

Prices: 5 lbs. 25c; 10 lbs, 40c; 25 lbs. 90c; 50 lbs. $\$ 1.75 ; 100$ lbs. $\$ 3.00$, postage, express or freight

\section{KAINIT (Genuine Imported)} Prices: 5 lbs, $20 \mathrm{c} ; 10$ lbs. $35 \mathrm{c} ; 25$ lbs. $60 \mathrm{c} ; 50$
lbs. $90 \mathrm{c} ; 100$ lbs. $\$ 1.50$, postage, express or freight

\section{SULPHATE OF AMMONIA}

The most concentrated nitrogenous top-dressing on the market. Contains ammonia in a form quickly a vailable but not readily leached from the soil. It is fine and dry, and easily spread by hand or by drill. The

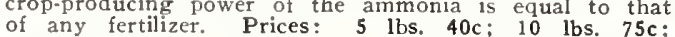
25 lbs. $\$ 1.25$; 50 lbs. $\$ 2.25 ; 100$ lbs. $\$ 4.00$, postage express. $\$ 1.25 ; 50$ lbs. $\$ 2.25$
This lime is especially prepared for use on the soi and is a combination of calcium-hydrate and calciumcarbonate, finely pulverized. Quantity required: Heavy soils, 2,000 to $6,000 \mathrm{lbs}$. to the acre; light, sandy soils, 1,000 to $3,000 \mathrm{lbs}$. to the acre, according to their ap parent need. Packed in $10 \mathrm{lb}$. bags. Prices: $10 \mathrm{lbs}$. $35 \mathrm{c}$; $50 \mathrm{lbs} . \$ 1.50 ; 100 \mathrm{lbs}$. $\$ 2.75$, postage, express or freight extra.

\section{VAN ANTWERP'S 8-4-4 GARDEN FERTILIZER}

A very desirable high grade all around fertilizer for vegetables, lawns, flowers and bulbs. There is suffi cient ammonia to give tbe young plants a quick and vigorous start and maintain a bealthy growth. Grass and early garden truck need lots of phosphoric acid, which this fertilizer supplies. Prices: 5 lbs. 25c; 10 lbs. $40 \mathrm{c} ; 25$ lbs. $90 \mathrm{c} ; 50$ lbs. $\$ 1.50 ; 100$ lbs. $\$ 2.50$. postage, express or freight extra.

\section{STIM-U-PLANT}

\section{Makes a Wonder Garden}

This fertilizer comes in tablet form and you simply insert the tablets in soil near the plant. You can also dissolve them in water at the rate of four tablets to a gallon of water and apply as a liquid fertilizer. Com plete instructions for use with every package. Price: Small size (30 tablets) $25 \mathrm{c} ; 100$ tablets $75 \mathrm{c}$; large can ( 1,000 tablets) $\$ 3.50$ postpaid.

\section{VIGORO}

A specially prepared plant food made by Swift \& Co. igoro is a plant food supplying growing things with all the food needed for rapid growth. It is odorike grass seed. For vegetables, lawns and flowers. Prices: 5 lbs. 50c; 25 lbs. $\$ 1.75 ; 50$ lbs. $\$ 3.00 ; 100$ 


\section{INSECTICIDES for the GARDEN and FARM}

\section{You Can Buy Them With Our Profit-Sharing Certificates-See Page 3}
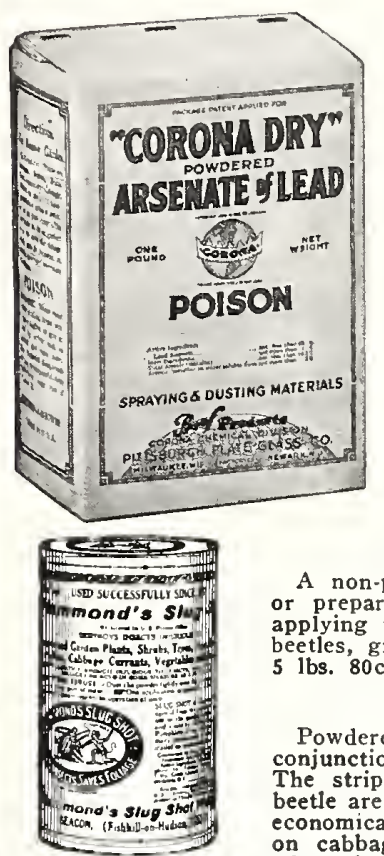

\section{Corona Dry Arsenate of Lead Powder}

Few progressive growers of fruit and truck crops use Paris Green, because it has been learned that it burns foliage. It is expensive to use paste arsenate of lead, because the percentage of arsenic is low and it contains from 50 to 60 per cent of water; so what is the use of paying transportation on water and the glass package. Which is cheapest? Insist on Corona Dry when you are in need of lead arsenate to spray your trees or crop for any leaf-eating insects. Use at the rate of 1 pound to 50 gallons of water, or if used dry, $\mathrm{T} / 2$ Corona Dry to half air-slacked lime, early in the morning while the dew is on the foliage. Price: $1 \mathrm{lb} .35 \mathrm{c} ; 4 \mathrm{lb}$. 100 lbs. $\$ 19.00$

\section{Slug Shot}

A non-poisonous powder insecticide; it requires no mixing or preparation, easily applied and not injurious to person applying it, or fruits and vegetables. Destroys potato bugs, beetles, green flies,
5 lbs. $80 \mathrm{c}$, postpaid.

\section{Tobacco Dust}

Powdered tobacco is a standard insecticide, often used in conjunction with Whale Oil Soap and Bordeaux Mixture. The striped cucumber (squash and melon) beetle and fleabeetle are repelled with this insecticide. It is an effective and economical remedy
on cabbages, squash, cucumbers, melons, etc. when the foliage is damp; it then sticks to the leaves. Our Tobacco Dust is of 2 lbs. $75 \mathrm{c}$, postpaid. Not prepaid, $25 \mathrm{lbs}$. $\$ 1.50 ; 50 \mathrm{lbs}$. $\$ 2.50$; 100 lbs. $\$ 4.50$.

\section{Bordeaux Mixture}

This mixture not only prevents blight, scab, rust, mildew, black-rot and other fungus diseases of plants and fruits, but improves the quality and largely increases the yield. It should be used on all vine-crops, grapes, cucumbers, melons,
tomatoes, etc. Potatoes especially respond generously to thorough spraying. To make a combined fungicide and insecticide, add a pound of paris green, or two pounds of arsenate of lead to 150 gallons of the diluted mixture. It may be applied dry or in wa wa
prepaid, 25 lbs. $\$ 3.75$.

\section{Powdered Sulphur}

Use on potatoes when cut for planting to prevent scab and bleeding: for mildew

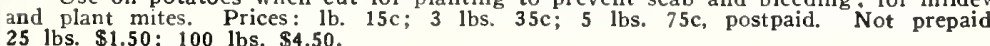

\section{Tree Tanglefoot}

A paste preparation for painting around the trunks of trees, in the form of a 5 lbs. $\$ 2.25$.

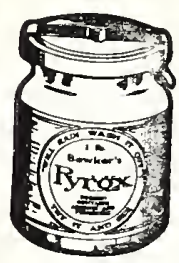

\section{Pyrox}

All-round spray which kills leaf-eating insects and prevents blights and fungous troubles, without injury, on fruit trees, grapevines, currant bushes, potatoes, cantaloupes, cucumbers, and other garden vegetables', also on rose bushes, shrubbery, etc. It is a creamy paste which looks like paint and "sticks like paint." It needs only to be mixed with cold water an it is ready to apply. Prices. lb. 50c: 5 lbs. $\$ 1.75 ; 101 \mathrm{lbs}$ $300-$ lb. barrels $\$ 43.50$. Cannot be mailed.

\section{Fish Oil Soap}

(Sometimes called Whale Oil Soap)

Effectually destroys the mealy-bug and nearly all lice on indoor plants and scale on palms. Recommended for San Jose scale and insects that infest the bark of trees. $\$ 1.00$.

\section{Vermine} For eel, cut worms and wire worms, working in the soil. It can
to all vegetation. Pint $65 \mathrm{c}$; quart $\$ 1.00 ;$ gal. $\$ 3.00$. Cannot be mailed.

\section{Bug Death}

A non-poisonous powder, in composition peculiar to itself inasmuch as it does not depend upon arsenic for its killing power. It is safe and sure to use on potatoes, tomatoes, cucumbers, melons, eggplants and general garden truck. Can be used either dry or as a liquid. This is one of the most popular insecticides, 1-1b. can $25 \mathrm{c}$ postpaid.

\section{Calcium Arsenate (Powdered)}

This is the proper and most effective powder for dusting on cotton for eradicating the boll weevil. It is the poison used proved that the weevil could be killed out at a profitable cost. which gives all intormation Prices: Sept. of Agriculture, 25 lbs. $\$ 3.25$. 100 lbs. $\$ 12.00$ Prices: Lb, $25 \mathrm{c} ; 5$ lbs., $\$ 1.00 ;$

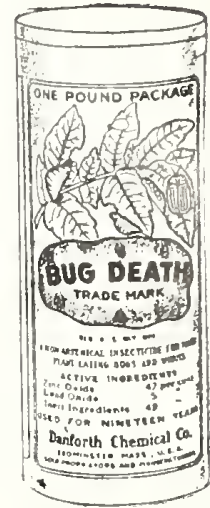

\section{Dry Lime-Sulphur}

Exactly like lime-sulphur except that the water has been taken out. No freight to pay on water, no leakage, never freezes. For fall and spring spraying, use 12 to 15 lbs. to 50 gallons water; stone fruits $1 \mathrm{x} / 2$ to 2 lbs. to 50 gallons water. To the summer spray add 2 lbs. arsenate 5 lb. pkg. $\$ 1.40$. Not prepaid, $25 \mathrm{lbs}$. $\$ 4.00 ; 100 \mathrm{lbs}$. $\$ 12.50$.

\section{Black Leaf " 40 ”}

A highly concentrated solution of Nicotine-Sulphate. Valuable for the destruction of aphis, thrips and other sucking insects. BLACK LEA trolling thrips and aphis on their Bermuda Onions. Full directions with
each can. Prices: $102.35 \mathrm{c} ; \mathrm{r} / 2 \mathrm{lb} \$ 1.25 ; 2 \mathrm{lbs}$. $\$ 3.50 ; 10$ lbs. $\$ 13.50$.

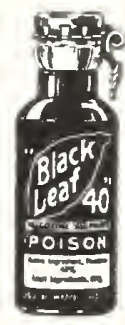
Cannot be mailed.

\section{Aphine}

It is a most effective remedy for green, black and white fly (the aphis), thrips soft scale, mealy bug, red spider, etc. It is a concentrated liquid, mixing readil Gowering plants you find this insecticide an effums and all greenhouse and outdoo pint $75 \mathrm{c}$; at $\$ 1.00$; $\$ 3.00$. Cannot be mailed.

\section{Para-di-Chloro-Benzene}

The only Peach Tree Borer complete instructions for use. Por 1 .lb. Tree Borers. Sold in $1.1 \mathrm{~b}$. cans containing Carbon Bi-Sulphide Fumigation by carbon bi-sulphide is recommended as the best method of con.
trolling wevils in Peas, Beans, Corn and other grains. 1-lb. can 50c; 5-lb. can
$\$ 2.00$ Cannot be mailed.

\section{Paris Green}

For Leaf-eating Insects. It is a strong poison and should be used with care. Mix one pound of paris green to 50 pounds of plaster, or with water to 150 gallone $20 \mathrm{c}$ vines and tender vegetables use a larger proportion of plaster and water. $1 / 4 \mathrm{Lb}$ Atlas Weed Killer (Non-Poisonous)

Weeds in walks, driveways, tennis courts, etc., can be safely and permanenely exterminted as easily as watering the gardens by applying Atlas Weed Killer. Although deadly to vegetation, it is harmless to humans, animals and birds, so can lions

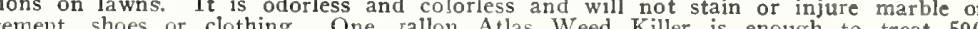
square feet Prices: Small Can (will make 21/2 rallons weed killer) 50c treat 500 1 gallon $\$ 2.00 ; 5$-gallon drums $\$ 8.00 ; 30$-gallon drums $\$ 37.50 ; 50$-gallon drume $\$ 55.00$. Cannot be sent by mail. Express or Freight shipments only.

\section{Gets-A-Fly}

The horses' and cows' friend. Drives away flics and all insects attacking live prick. Also good for lice on hogs, dogs, etc. Do not dis. Grafting Wax

The highest grade made with directions for use on every package. Price, $2 / 416$ $15 \mathrm{c} ; 1 / 2 \mathrm{lb}, 25 \mathrm{c} ; 1 \mathrm{~b} .40 \mathrm{c}$, postpaid.

\section{VAN ANTWERP'S INSECTICIDE (SCHNARR'S IMPROVED)}

\section{The Best Insecticide for White Fly and Scale on Citrus Fruits}

Van Antwerp's Insecticide (Schnarr's Improved) is manufactured in our own chemical laboratory and is used extensively throughout the South for spraying all kinds of Citrus fruits and deciduous trees infested with White Fly or scale insects. It has been thoroughly tested by expert entomologists and is highly recommended by them as a safe and efficient spray for sucking insects like White Fly, Maple Scale, Purple Scale, Long Scale, San Jose Scale and Oak Scale.

In the vicinity of Mobile all the Satsuma Orange growers use Van Antwerp's insecticide for their trees and say it's a spray without competition.

For White Fly and Scale use at the rate of 1 part of this insecticide to 60 parts of water and for deciduous Fruit Trees, also Pecan Trees, use 1 part to 20 part of water. We have this insecticide put up in all sizes, including a small 8.ounce bottle for those who have a few trees in their garden to spray.

Write us for a free copy of our 40-page book entitled "THE MORE COMMON INSECT PESTS AND PLANT DISEASES OF THE GULF STATES," written by Prof. H. P. Loding, who is recognized as one of the leading entomologists in the

Our planting calendar on page 4 tells you what months of the year to spray with Van Antwerp's Insecticide and also the quantities to use.

Price. Van Antwerp's Insecticide. Small garden size bottle ( 8 ozs.) 35c postpaid; $1 / 2$ gallon can $85 \mathrm{c} ; 1$ gallon can $\$ 1.50 ; 5$ gallon can $\$ 6.75 ; 10$ gallon can $\$ 12.50 ; 25$ gallons \$28.75; 50 gallons $\$ 50.00$. Purchaser pays transportation charges. 


\section{MULFORD CULTURES}

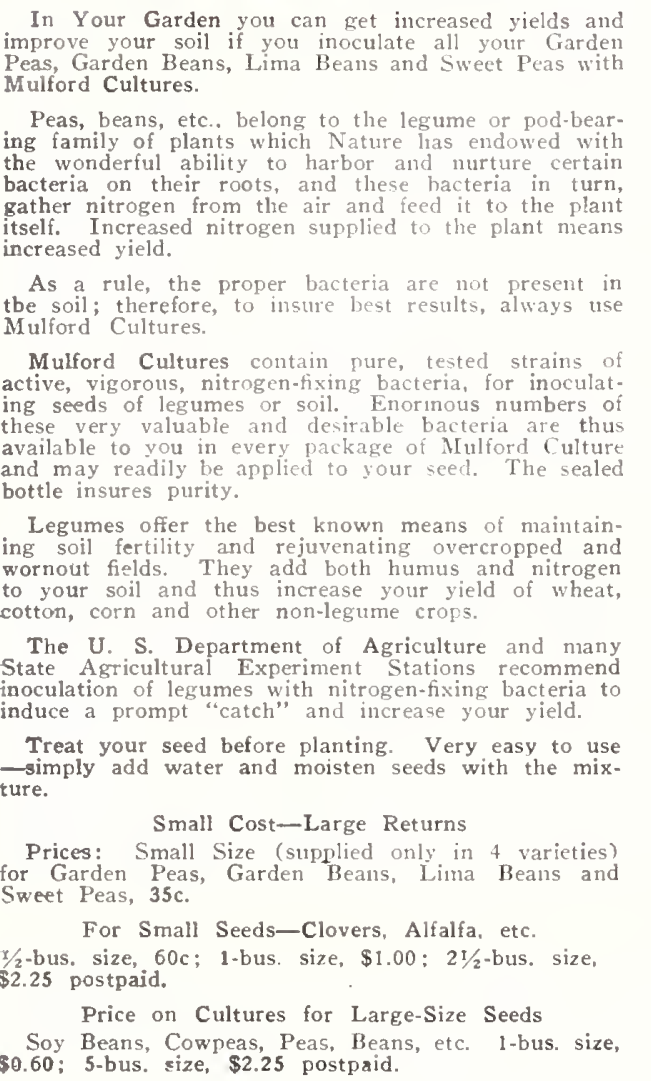

\section{FARMOGERM SEED INOCULATION}

A Seed and Soil Inoculant That Increases Crop Production and Greatly Improves the Soil.

New Sizes-New Prices Seeds of all leers, Alfalfa, Sweet Clovers, Beans, Peas, Vetches, Soy
Beans, Cowpeas, etc.- will vield far better results if inoculated with FARMOGERM, and in addition leave in the soil a heavy deposit of nitrogen which

Farmogerm - Always Fresh

Farmogerm is a pure culture of nitrogen-fixing bac teria, selected for maximum vitality and ability to transtorm nitrogen from the
and deposit them in the soil.

By reason of the patented stopper which admits air and excludes contaminations, Farmogerm is guaranteed for five years--always fresh--always stron

Farmogerm will reduce your fertilizer bills, give 作 hodules on the roots of legumes.

When ordering, be sure to state what crops you wish to inoculate.

Farmogerm is so inexpensive and is so effective an insurance that you can not afford to sow legume

\section{NEW LOW PRICES}

For Small Seeds-Clovers, Alfalfa, etc.

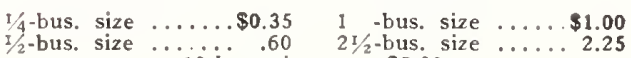

Special Reduced price on Cultures for Large-Size Seeds-Soy Beans, Cowpeas, Peas, Beans, etc. 1/2-bua size, 35c; 1-bus. size, 60c; 5-bus. size, $\$ 2.25$.

Special Garden Size for Garden Peas, Beans and Sweet Peas, 25c. These prices are postpaid. Full

\section{ANTROL} Against Ants

They Stand on Guard Like Sentinels

Antrol containers offer you three distinet advan-

First, this modern old-time methods.

作 作

pecom, Antrol is safe to use around children or And third, the Antrol method is in accordance with the methods adopted by the United States Govern The

These three advantages of Antrol make it the most popular ant control on the market.

ants effectively, safely are, protect your home from PRICES:

Antrol Cottage Sets (containing 9 jars and 6-0z. bottle of Syrup)

Pint Bottles of Syrup.

\section{SNAROL}

Kills Garden Pests $\bullet$ Stops Their Damage!

Snarol is a scientifically prepared meal that you simply broadcast on the ground around tbe flowers and is quickly exterminated. This eats it as a food trol unlike many others, is trol, unlike

Snarol is widely endorsed by leading nurseries, to use and and gardeners everywhere. It is easy which may be eating the tender shoots of your favorite flowers, vegetables or plants.

1-lb. Carton

3-lb. Carto
15-lb. Bag PRICES :

\section{CYANOGAS (Calcium Cyanide)}

A. Dust. This is a poisonous gas in powder form and is used extensively for fumigating greenhouses, etc. Cyanogas is especially recommended for Ants, Chinch Bugs, Gophers, Land Crabs, Moles, Rats, Salamanders, Turtles, etc. Complete instructions for use with every can. It cannot be mailed. Prices: $1 \mathrm{lb}$. can, $60 \mathrm{c} ; 5 \mathrm{lbs} ., \$ 2.50$. Shipment by Express only.

\section{BIRD \\ SEED \\ AND \\ BIRD \\ SUPPLIES}

\section{Van Antwerp's Ely Bird Seed Mixture}

Thousands of boxes of our famous Ely Bird Seed Mixture are used every year by the large canary breeders and fanciers. The Ely Bird Seed is made from the very finest recleaned bird seeds and blended in proper proportions to keep the birds in perfect health and song. Every box of seed contains a piece of cuttle fish bone. The tremendous sale of our Ely Bird Seed always assures you of getting strictly fresh seed. Price-Large Box, 20c; by mail, postpaid, $25 \mathrm{c}$.

Van Antwerp's Bird Gravel.......15c; by mail, $20 \mathrm{c}$ Bird Manna

Bird Nesting

Bird Bitters

Bird Mite Powder

Moulting Pepper

Spratt's Color Food, Red.

Spratt's Color Food, Orange.
$15 \mathrm{c}$; by mail, $18 \mathrm{c}$

$10 \mathrm{c}$; by mail, $12 \mathrm{c}$

$25 \mathrm{c}$; by mail, $30 \mathrm{c}$

$25 \mathrm{c}$; by mail, $30 \mathrm{c}$

$25 \mathrm{c}$; by mail, $30 \mathrm{c}$

$25 \mathrm{c}$; by mail, $30 \mathrm{c}$ $25 \mathrm{c}$; by mail, $30 \mathrm{c}$
Seed and Water Cups, Opal or Glass.15c; by mail, 20c Bird Bath Dishes, China..........20 Red Mite Liquid.............25c; by mail, $30 \mathrm{c}$ Wire Bird Nests...............20 ; by mail, $25 \mathrm{c}$ Merican Salve for Birds' Sore Feet.,25c; by mail, 30c Cuttle Fish Bone with Holder....... 5c; by mail, 10c Fish Food-Wafers for Gold Fish...10c; by mail, 12c

\section{Re-Cleaned Bird Seeds}

Canary Seed, Plain

Rape Seed for Birds

Hemp Seed

Sunflower for Parrots.

Sprast's Parrot Food.

Spratt's Canary Mixture.

Van Antwerp's Ely Bird Seed Mixture.

$20 \mathrm{c} \mathrm{lb}$., postpaid; 5 lbs., $75 \mathrm{c}$, not prepaid 20c 1b., postpaid; $5 \mathrm{lbs}$., $75 \mathrm{c}$, not prepaid 20c lb., postpaid; 5 lbs., 75c, not prepaid $20 \mathrm{c} \mathrm{lb}$, postpaid; 5 lbs., 60c, not prepaid 20c, postpaid 25c, postpaid 25c, postpaid

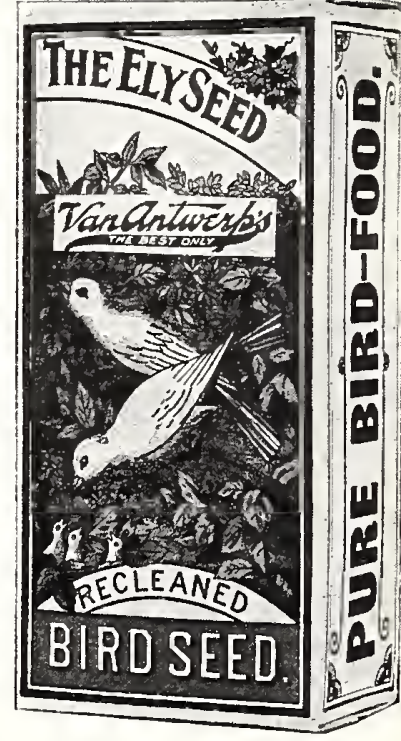


The Semesan disinfectant family, com prising Semesan, for general crops, Semesan Jr., for corn, and Semesan Bel, for potatoes, has proved to be the grower's solution of the disease hazard in farming.

Semesan provides the one effective method of controlling the various damping-off diseases. It is being used with wonderful re sults in all sections of the country on grains, field crops, vegetables, flowers and ornamentals. Brown Patch of grasses, a disease which swiftly destroys the expensive turf of golf greens, estate lawns and tennis courts, can be prevented, and, if treated soon enough, cured with Semesan.

Easily applied-little skill required-at a cost of only $1 / 4 \mathrm{C}$ to $1 \mathrm{c}$ per pound of seed.

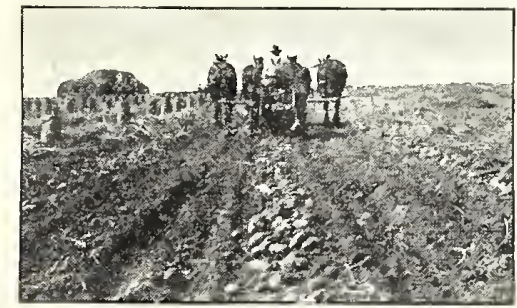

Semesan Bel Improves Potato Yields

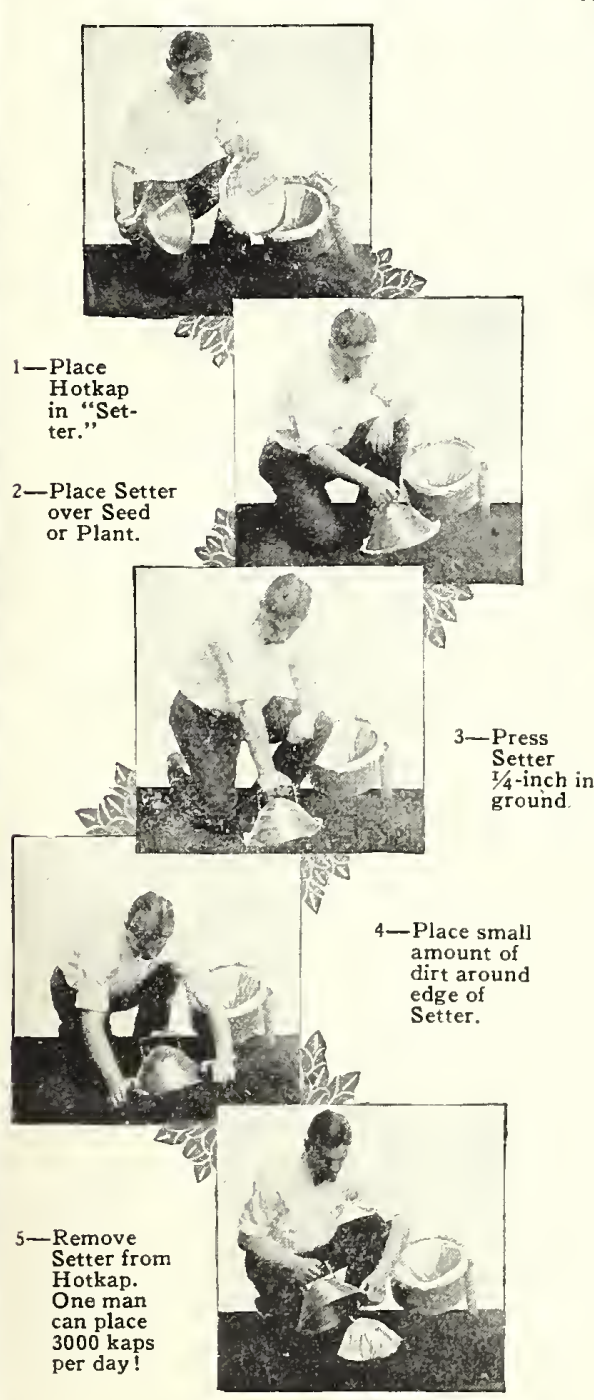

The cheapest crop protection you can buy Semesan Jr. is used as a dust disinfectant to control the ear, root and stalk rots of corn. In tests conducted in both Illinois and Iowa by the Federal and State Governments, Semesan Jr. increased yields from diseased seed by varying amounts up to $38 \%$. These tests confirm the experience of ther agricultural experts and practical farmers who report increased corn crop yields from Semesan Jr.-treated seeds of $20 \%$ to $40 \%$ or more. The $33 \%$ increase shown in the illustration is the result of Semesan Jr. seed treatment.

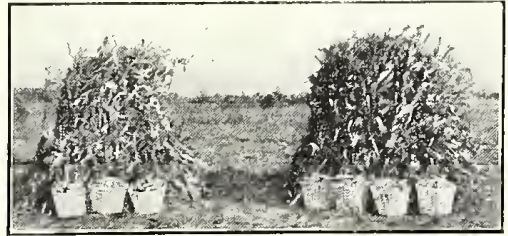

Semesan Jr. Generally Increases Corn Crops

Semesan Ir is applied only as a dust, at the rate of 2 ounces per bushel of seed. The cost therefore ranges from only about $4 \mathrm{c}$ an acre of field corn to 6 or $7 \mathrm{c}$ per acre of sweet corn. Send for Semesan Jr. Corn Pamphlet with full directions.

Semesan Bel is used especially for the seed disinfection of white and sweet potatoes. It has the remarkable property

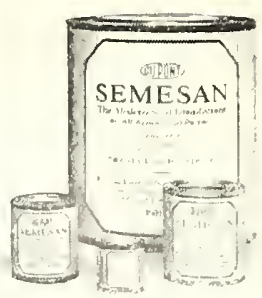

of destroying many disease germs and at the same time stimulating seed pieces to speedy germination, healthy growth, early maturity and the production of larger crop yields.

Semesan Pel is applied to whole or cut seed pieces as a whitewash-like mixture by adding the proper amount of water by the instantaneous dip method. Because of its effective control of the common potato diseases a higher percentage of potatoes of certified grade can be obtained through its use than from any other practical means. Ask for Semesan Bel Potato Booklet.

Prices for Semesan Disinfectants (Not Mailable)

SEMESAN

$2 \circ z . \$ 0.50 \quad 25$ lbs.

$80 z .60 \quad 50$ lbs.

1 lb. ..... 2.75100 lbs.

5 lbs. .... $13.00 \quad 300$ lbs

$13.00 \quad 300$ lbs.

4 oz. $\$ \$ 0.60 \quad 25$ lbs.

$1 \mathrm{lb} . \cdots \cdots \cdots, 1.75 \quad 50 \mathrm{lbs}$

37.50
72.50

5 lbs.

8.00100 lbs.

140.00

SEMESAN BEL

1 lb. ....\$ $1.75 \quad 50$ lbs. ... \$72.50

$5 \mathrm{lbs}$ $\begin{array}{rr}\$ 1.75 & 50 \mathrm{lbs} \\ 8.00 & 100 \mathrm{lbs}\end{array}$

140.00

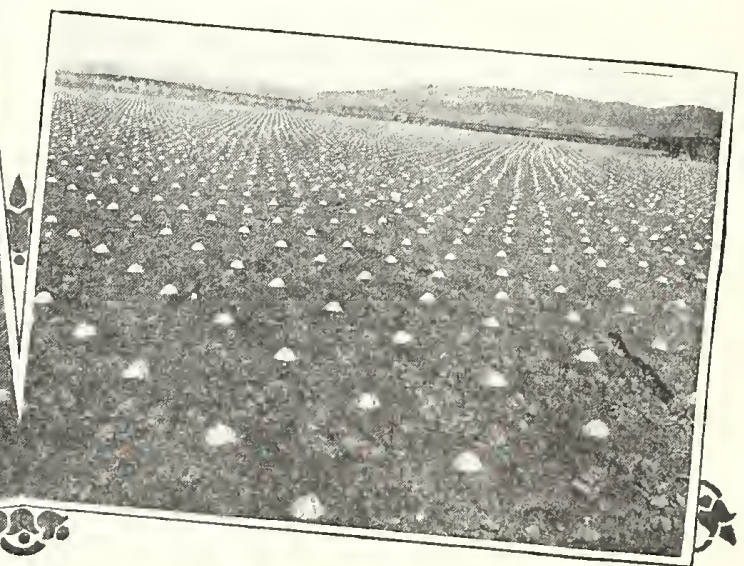

\section{HIGHER PRICES FOR YOUR CROP}

\section{THIS AMAZING NEW METHOD OF PLANT PROTECTION GETS YOU HIGHER PRICES FOR LARGER AND QUICKER CROPS}

Last year thousands of growers added to the value of their vine crops by using Germaco HOTKAPS-shown above. This remarkable invention consists of a scientifically constructed wax paper cone that you place over each plant. Thus they are miniature hot-houses that protect plants from frost, wind, rain, insects and ground crusting.

HOTKAPS not only protect plants, but make them grow hardier and faster. Thus you get a greater crop production to market earlier for higher prices!

You can add to your next year's profit with Hotkaps. They cost but a fraction over a penny each. One man can "set" 3000 Hotkaps per day. They not only bring you higher prices, but are a method of crop insurance-against the danger of the elements

Prices of HOTKAPS-50 kaps $\$ 1.00 ; 1$ Co for $\$ 1.85 ; 250$ for $\$ 3.50 ; 500$ for $\$ 6.25 ; 1,000$ for $\$ 11.50 ; 5,000$ for $\$ 55.00$, postage or express paid by us in lots up to 1,000

Germaco Hotkap Setters, a labor saving device for setting Hotkaps accurately and quickly into the ground. Price $\$ 2.25$ each-postage or express extra. 


\section{Van Antwerp's Complete Garden Service Implements and Tools for Your Garden}

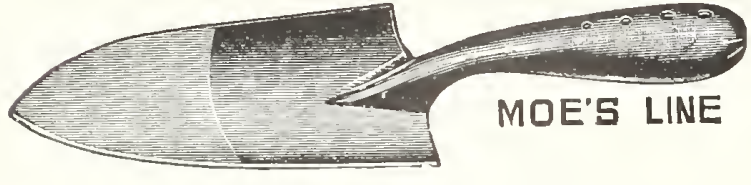

No. 80 Steel Garden Trowel

Pressed steel, all in one piece; ground and polished point. No costpaid, $30 \mathrm{cts}$. Not prepaid, $25 \mathrm{cts}$

No. 85 Galvanized Garden Trowel

Made of a single piece of heavy steel; handle and blade in one piece. By mail postpaid, $25 \mathrm{cts}$. Not prepaid, $20 \mathrm{cts}$.

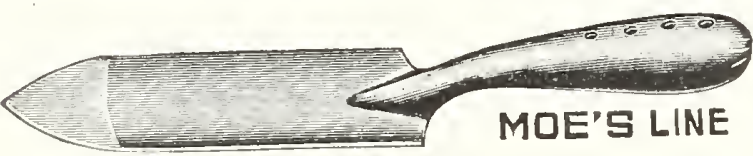

No. 81 Transplanting Trowel

The blade is 6 inches long, $13 / 4$ inches wide. The entire trowel is made of one piece of pressed steel. By mail postpaid, $30 \mathrm{cts}$. Not prepaid, $25 \mathrm{cts}$.

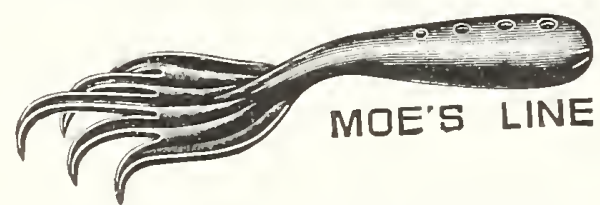

No. 82 Steel Garden Weeder

One piece pressed steel, finished in black enamel; has five steel ingers; a usetul and serviceable weeder. By mail postpaid, 30 cts. Not prepaid, $25 \mathrm{cts}$.

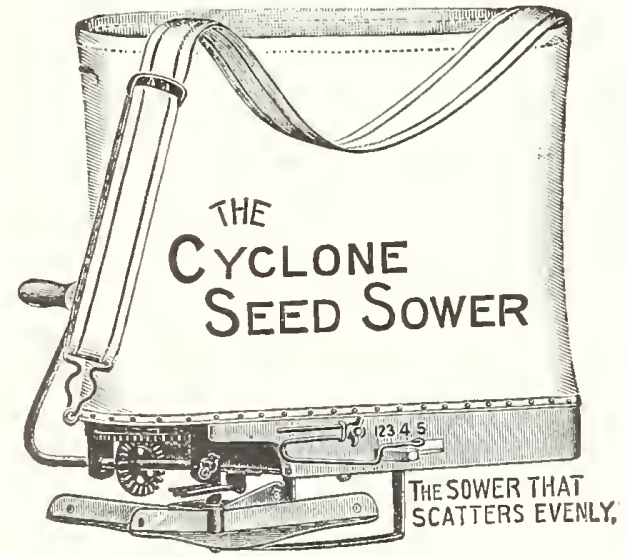

Cyclone Broadcast Seeder

Cyclone-(New Improved Model). An accurate, portable seeder, tor all broadcast sowing or fertilizing. Fits comfortably over shoulder; provided with automatic adjustment for stopping flow of $\$ 32.25$ postpaid.

Wooden Garden or Pot Labels You can mark the rows of vetgetables in your garden or the different thowers with these garden labels. They are painted whit

Length

4-inch
5-inch

6-inch

8-inch

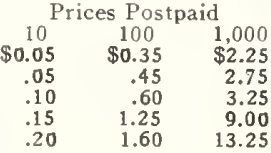

50 sold at 100 rate; 500 at 1.000 rate

Labels $-31 / 2$ inch copper wired wooden labels to tie on trees or shrubs. $10 \mathrm{c}$ per doz.; $40 \mathrm{c}$ per $100 ; \$ 2.65$ per 1,000 .

Labels-Copper. An indestructible copper label for use on trees, hrubs, etc. $30 \mathrm{c}$ per doz.; $\$ 1.75$ per 100 ,

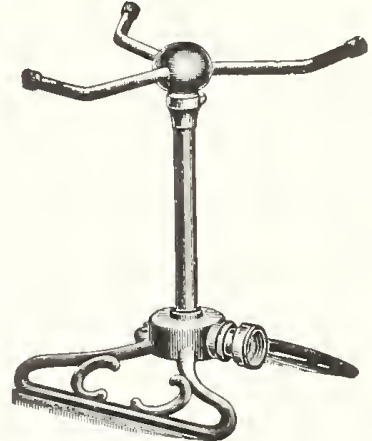

No. 200 Cyclone Sprinkler

Three-Arm Lawn Sprinkler, which can be oper ated with a moderate pressure, covers a wide area and distributes the water evenly. The revolving arms throw the water in a fine spray into the air and the motion produces a fine mist. Height, about 1 foot. Each, $\$ 2.25 ; 3$ for $\$ 5.50$, postpaid.

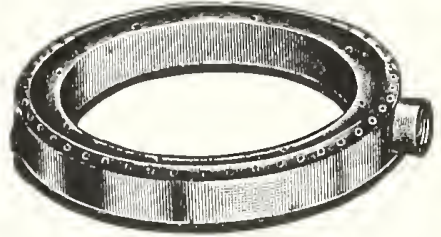

No. 225 The Ring Lawn Sprinkler

Easily moved about the lawn; made of polished brass; light, durable and economical. Each, \$1 postpaid.

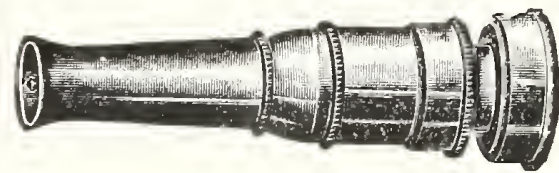

No. 345 Adjustable Spray Nozzle

A very popular adjustable Nozzle. It gives a copious spray or a well-defined full stream. Has a positive shut-off, by turning the barrel of the nozzle. $75 \mathrm{c}$ postpaid.

Hose Bands, Couplings, Etc.

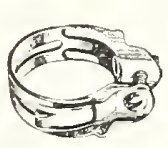
Hose Menders, each ..... $\$ 0.10$ Brass Couplings, per pair. Gem Graduating Nozzles. Hose Clamp, each Garden Hose Washers, each. 10 3 for $5 \mathrm{c}: 12$ for $15 \mathrm{c}$.

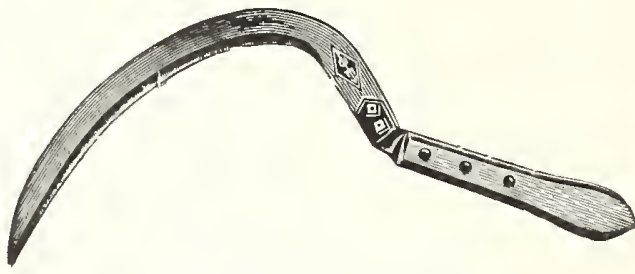

Grass Hooks or Sickles

No. 3R.B. English. Riveted back. Each, 85c

No. D.E.65. Domestic. Best quality, 65c postpaid.

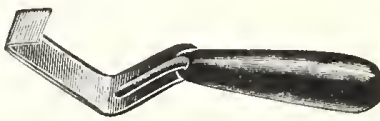

Hand Weeder

No. 87 Hand Weeder. A real labor saver; fits the hand nicely; made of one piece of hard, stiff steel ground edges, By mail postpaid, $30 \mathrm{cts}$. Not pre

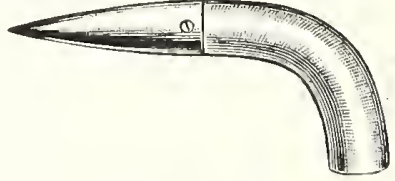

No. 218 Dibbles

Iron Point, large, each $75 \mathrm{c}$ postpaid.

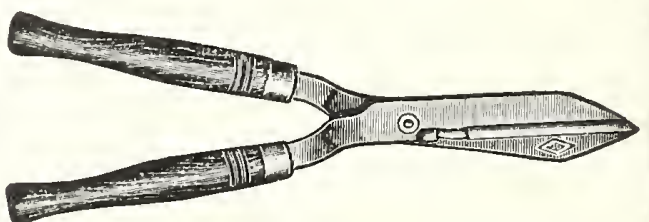

Hedge Shears

For both trimming hedges and cutting grass under fences, bushes, etc.

The "Notches" at the heel of the blade is for cutting branches.

English Hedge Shears

8 -in, blades, with notch, $\$ 3.00$ postpaid.

9 -in. blades, with notch, $\$ 3.50$ postpaid.

American Hedge Shears

The best quality manufactured.

9-in. blades, with notch............... \$2.25

10-in.

Paper Flower Pots, Neponset

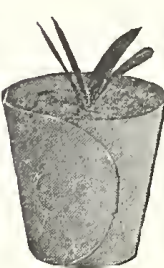

Very economical; waterproof; can bes economical; waterproof; can Diam. 100 $21 / 2$ in $\quad 1 \ldots \ldots$. $\$ 0.15 \quad \$ 0.60$ in. ............ .20 $\quad .80$ $1 / 2$ in $r .25 \quad 1.00$ in. $\ldots \cdots \cdots+.35 \quad 2.00$

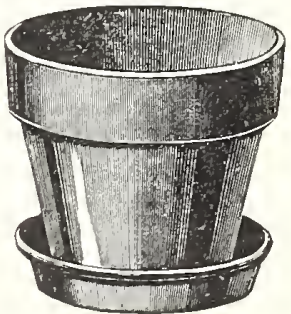


SPRAYERS ${ }_{\mathrm{THE}}^{\mathrm{FOR}}$ GARDEN

\section{Junior Sprayer}

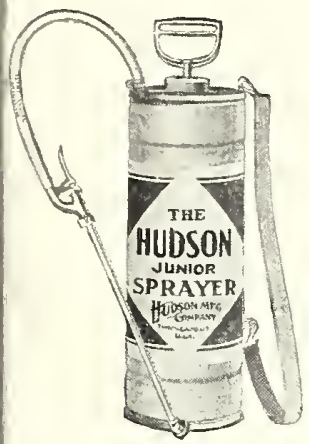

The Junior Sprayer is made for the man who n e e d s a medium size high pressure compressed Air Sprayer. It is particularly adapted for the backyard garden or $\mathrm{small} \mathrm{truck}$ farm, for use around the chicken house, in the dairy barn, hog pen, or for disinfectants in hotels, restaurants, theatres and other public buildings. It will do models can. for it differs from them only in capacity. It is substantially made and will give entire satisfaction.

Tank is either rust-resisting copper bearing galvanized or prime brass sheet, as ordered. Capacity approximately $21 / 2$ gallons. Pump is seamless brass. Attaches to tank by a urass threaded cap operated by turning the " $D$ " handle. Nozzle is our "Perfection" automatic shut-off nozzle. Operates perfectly at any pressure. Harilles all solutions. Is regularly equipped with 22 -inch brass extension rod as shown. Standard $1 / 4$-inch iron pipe threads per mit using a longer rod if desired.

Standard Package-One in heavy fibre carton. No. 140G. Junior Galvanized Tank.

No. $140-B$. Junior Brass $\$ 7.00$ Postpaid

\section{Misty Sprayer}

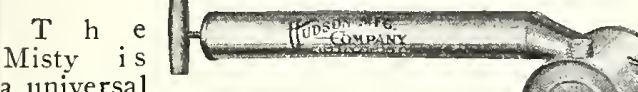

favorite for use in and around the

house, yard, garden, chicken house,

etc. Pump is made of heavy tin.

passes heavy tin. The point of the pump dered. Syphon tube is set at proper angle by a jig and carefully soldered. Construction combines strength, simplicity, neatness and uniform efficiency in operation. Heavy plunger rod and good leather. Capacity-One Quart.

No. 452. Misty Sprayer-heavy tin.

50c Postpaid

Seeder-Single or Double Wheel Cultivator

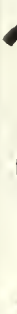
The No, 201 Machine is a combination outfit which may be used as a hill or drill seeder double or single wheel cultiditions require. It has all

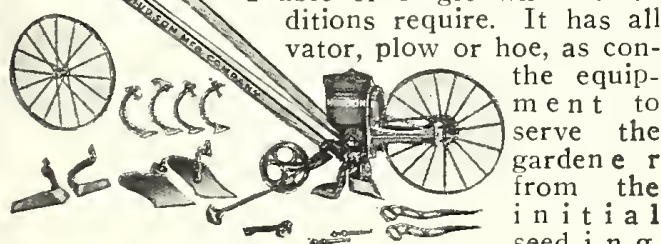
until final cultivation. It is readily converted from one use to another; the change from seeder to cultivator being accomplished by removing two red-headed bolts. One standard frame is used throughout.

As a seeder, this machine opens the furrow, drops the seed, closes the furrow, packs the earth, and marks the next row-all in one operation. The seed regulator is made entirely of brass, with openings die cut to insure absolute uniformity. This gives perfect control of the seed flow and insures a uniform drop. Sows all seeds from beans down to the finest garden variety, in continuous drills or hills $4,6,8,10$, 12 or 24 inches apart. Adjustments in furrowopening shoe and furrow coverer permit planting at any depth up to 2 inches.

One in wood box, handles bundled separately. Shipping weight 56 pounds.

No. 201. Seeder and Cultivator

\section{Perfection Sprayer}

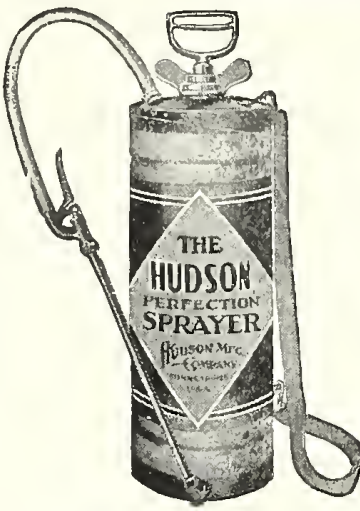

For general high pressure purposes, the Perfection is the very best. Easily operated and economical to use for whitewashing, disinfecting, deodorizing, cold water painting, etc. Best materials, best construction and best quality through Tank is e ither brass or rust resisting copper bearing steel sheet. Capacity seamless brass tubing. Fastens to tank by heavy threaded malleable cap which screws onto brass tank collar.

This unit construction combines strength, simplicity and easy access to parts. Nozzle is designed for high pressure work. Handles any solution and works perfectly under all presures.

Regularly equipped with 12-inch brass extension rod as shown. Permits the operator to quickly and easily reach low-lying plants, under surfaces of leaves, all parts of trees, shrubs or vines, or the nooks and corner of the poultry house, dairy barn or hog pen, without tiresome bending or climbing. Fitted with standard $1 / 4$-inch iron pipe threads so that a longer rod can be used if desired.

Standard Package-One in heavy fibre carton.

No. 110G. Perfection, Galvanized Tank

No.......................... Postpaid $\$ 9.00$ Postpaid

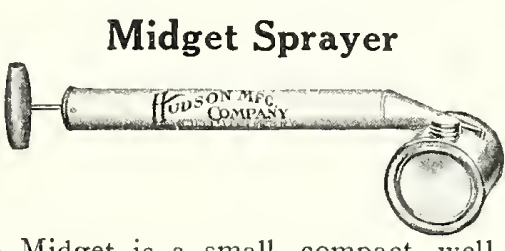

The Midget is a small, compact, well made sprayer, especially adapted for use in and about the home. Will handle all liquids satisfactorily. The nose of the pump passes through the top of the tank keeping the air nozzle and spray tube always in line. This construction adds a great deal to the strength and durability of the sprayer. Carefully tested before shipping and will give entire satisfaction.

Pump is made of heavy tin. Tank is made of heavy tin, capacity about $3 / 4$ pint.

No. 202. Midget Sprayer-Heavy tin.

30c Postpaid

\section{Cadet Duster

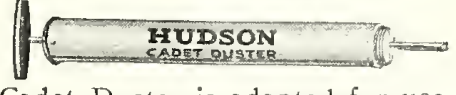

The Cadet Duster is adapted for use with all insect powders, Because of its size and efficiency it is a favorite with the housewife in applying roach, ant, and various bug powders. It is frequently used around restaurants, soda fountains, offices, stores, etc.

No. 663. Cadet Duster.

50c Postpaid

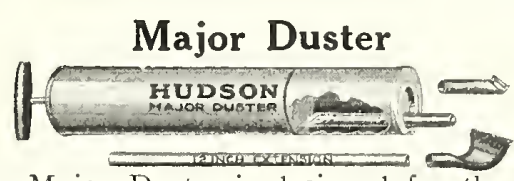

The Major Duster is designed for the home gardener, the small truck farmer or fruit grower, for use in and around the home, dairy, etc. It will handle all dry powdered insecticides very satisfactorily.

\section{AND HOME}

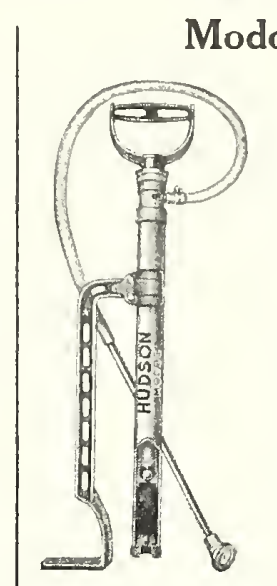

Modoc Spray Pump terchangeable nozzle discs which produce an desired spray from the very finest fog to a solid stream. All parts except the handle and foot rest are brass.

Standard Package-One in heavy fibre carton. No. 122. Modoc Spray Pump...\$4.00 Postpaid

\section{Continuous Sprayer}

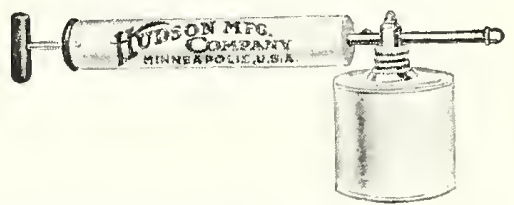

The Improved Hudson Continuous Sprayer is con Operates very defachable tank for convenience in filling sprayer has an adjustable nozzle which can be set to throw the exact type of spray wanted. Adjustable from a straight stream to a very fine mist. Made of heavy brass. Capacity one quart. cap. All working parts are brass and accessible for cleaning. Lockseamed and No. 427B. Continuons Sprayer-All Brass.

$\$ 1.25$ Postpaid

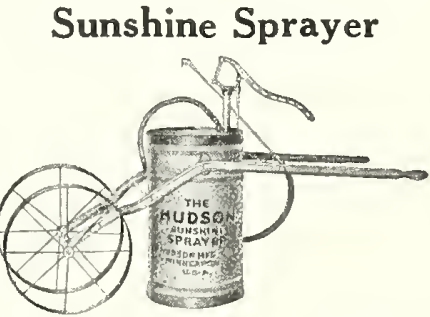

Tha Sunshine Sprayer fits the needs of the florist or nursery man because its width permits its use between the narrow rows. It is also adapted for orchards, vineyards and truck gardens; for whitewashing poultry houses and dairy barns; spraving stock dips, treating ornamental shrubbery, flowers, etc. Its high pres sure and easy portability adapt it for work of al kinds. Its two wheeled construction enables it to be used on hillsides or on uneven ground without danger of tipping.

Pump is fitted with dasher type agitator driven by each stroke of the plunger. Valves are bronze balls mounted in a brass cage, accessible without dismantling the pump. Cylinder is seamless brass. Air chamber has ample ca pacity for high pressure and steady discharge. Tank is heavy gauge copper bearing galvanized steel; capacity $121 / 2$ gallons. Discharge equip ment consists of 5 feet of $3 / 8$-in. 5 -ply spra hose, 2 foot iron pipe extension and angle spray nozzle.

Standard Package-One in a crate. Shipping weight 43 pounds. $\$ 1.25$ Postpaid 


\section{EVERYTHING}

Drop-Bottom Water Fountain

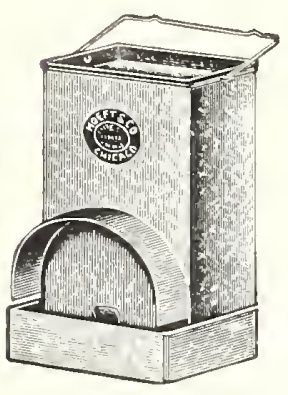

A practical durable fountain. Fasy to fill and easy to clean. Made of the best quality galvanized iron. May be hung on the wall, out of the litter Suitable for chicks. fowls or pigeons. Fitted with wire handles, so that two or more fountains, back to back can be carried in one hand. Price, No, 40, 2 quarts, 90c: No. 41, 1 gallon, \$1.10; No. 42,2 gallons, $\$ 1.40$. By mail add $15 \mathrm{c}$ each for packing and postage.

Single Chick Feeding Troughs

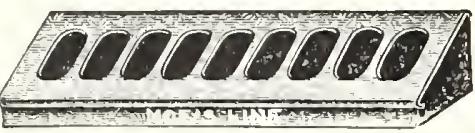

Just the thing for feeding baby chicks; has sliding No. easily cleaned; no sharp edges to injure chicks No. 56-18 inches long: Each, $40 \mathrm{c}$; by parcel post, $55 \mathrm{c}$. No. 57-24 inches long; Each, 50c; by parcel post, 65c.

Double Feeding Chick Troughs

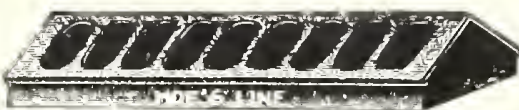

Has two sides, otherwise identical with the single

No. 58-12 inches long: Each, $40 \mathrm{c}$; by parcel post, $55 \mathrm{c}$. No. 59-18 inches long: Each, $55 \mathrm{c}$; by parcel post, 55c

Eclipse Feeding Trough

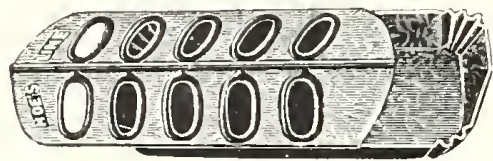

A fine popular-priced feeding trough, made of galvan ized iron and intended for chicks and growing stock. seams, rivets or solder used. Sliding top makes them easy to fill and keep clean. Made in two sizes. Ne. 27-10 inches, 10 holes.........25c; postpaid, $35 \mathrm{c}$ Ideal Poultry Punch

No. 39-Ideal Punch-A new improved Punch. Work $31 / 2$ in. Nickel plated. Each, postpaid....... Length,

FOR THE POULTRY FARM

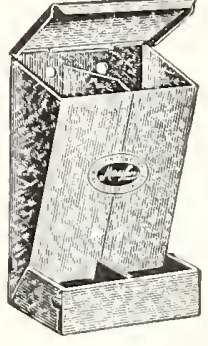

Grit and Shell Boxes

\section{No. 45-A special feed hopper and grit} box for baby chicks. Thoroughly well No. 45-Two compartments, No. 9-Economical and practical for feeding grit, shells, etc, keeps the fowls in prime, healthy condition. No. 90-Four Compartments,

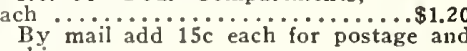
packing.

\section{Round Baby Chick Feeder}

The most convenient feeder on the market Can also be used for water Two sizes, No 11,6 inches with 8 holes, and No. 12, $81 / 4$ inches with 12 holes. Price: No, $11,15 c$, by mail 25 c, No. 12 , $25 \mathrm{c}$, by mail, $35 \mathrm{c}$
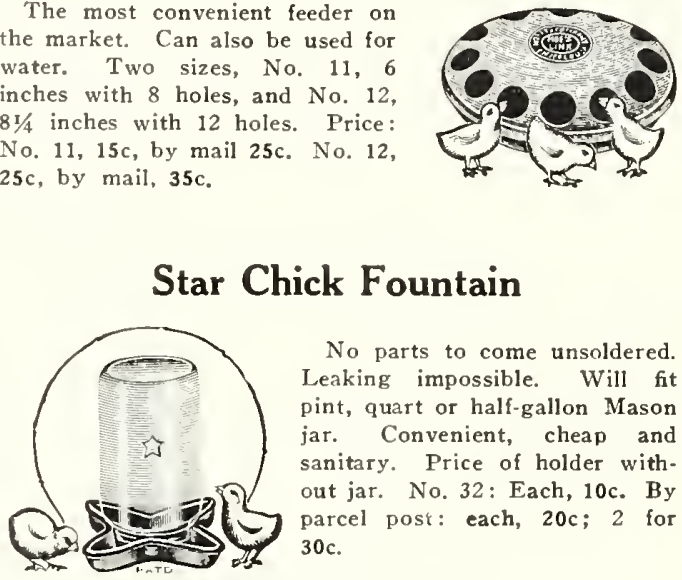

No parts to come unsoldered. Leaking impossible. Will fit pint, quart or half-gallon Mason jar. Convenient, cheap and sanitary. Price of holder without jar. No. 32: Each, 10c. By $30 \mathrm{c}$.

\section{Bottom Fill Fountains}
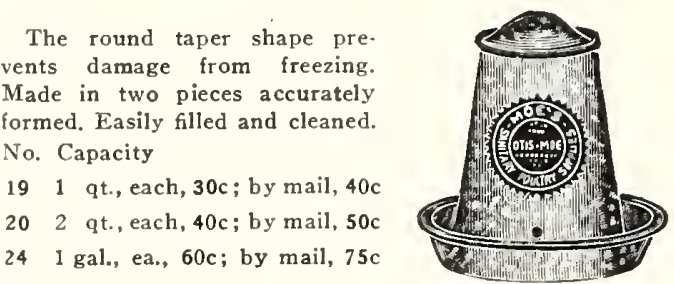

\section{Glass Nest Eggs}

Made of first-class flint glass, the same size and color of a hen's egg. They do not break easily. Will last a lifetime. Keep one egg in every nest. Price, 6 for $25 \mathrm{c}, 12$ for $40 \mathrm{c}$, postpaid.

\section{Poultry Punch}

No. 38-A popular and practical punch. Makes a clean perforation and does not bruise the foot. Each, postpaid..\$0.25

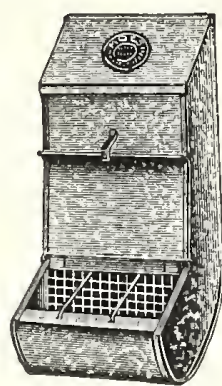

Never Clog Dry Food Hopper

One of the best hoppers on the market. Does not clog, no matter how coarse the mash is.

No. 35-12-qt. capacity, $\$ 1.50$; by parcel post, $\$ 1.75$.

No, 36-18. cat capacity, $\$ 2.00$ by parcel post, $\$ 2.30$

No. 37-24-qt. capacity, $\$ 2.80$; by express only.

\section{Celluloid Colored Leg Bands}

Best quality. Made of Celuloid in Six sizes and Ten colors-White, Black. Dark Blue, Light Blue, Red, Pink, Garnet, Green, Yellow, Purple.

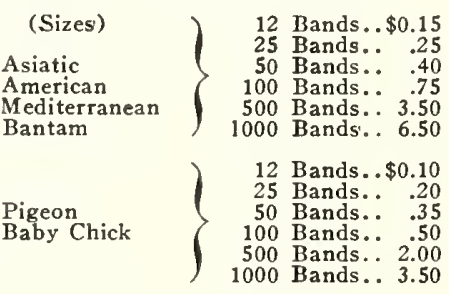

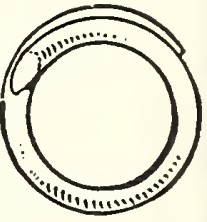

Aluminum Leg Bands

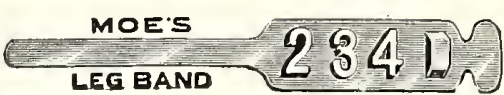

No. 130-Aluminum, with extra large raised numbers. applied.

Price-12 for $15 \mathrm{c} ; 25$ for $25 \mathrm{c} ; 50$ for $45 \mathrm{c} ; 100$ for $75 \mathrm{c}$; for $\$ 3.50 ; 1,000$ for $\$ 6.00$, postpaid.

No. 5783

Tycos Incubator

Thermometer

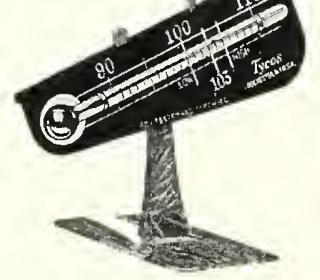

When used with Stand

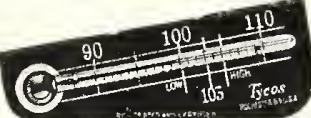

When used without Stand
Tycos Incubator Thermometers

The best incubator manufactured is worthless unless the thermomcurate.

No. $5776 \ldots \ldots .75 c$ Certified Thermometer

\section{Incubator}

Hygometers

Millions of chicks die in the shell every year for the want of proper moisbator Hygrometers do not reate exactly what conditions are, so that if not correct, they may be made No. 5796 , postpaid, $\$ 1.75$

\section{INTERNATIONAL SANITARY CHICK HOVER}

\section{THE ONE PERFECT BROODING DEVICE}

No one realizes better than we do that the entire success or failure of poultrymen depends upon tbeir brooding system. They must be able to raise as large a number of the cbcich

We have seen poultrymen start out with practically notbing and grow into mammoth industries; we have seen others start with everything and fail. And to one thing can be traced this success or failure-the brooder that had to raise the chicks to large, healthy birds if the business was to succeed.

Large, unwieldy broods are never given the care they should be given. Sanitation demands smaller individual broods it you wish to succeed. The unit of 100 chicks have been proven to be the most satisfactory. This point should be given some thought and consideration.

The Sanitary Hover is endorsed by leading poultrymen such as Mr. Delano, owner of the Owen Farms, where over Circular in shape; is made of metal throughout, and fireproof. The Hover sets on floor just as a mother hen does. The
amp can be lifted out througb the top and the operator does not need to kneel in the dust. There is no possibility of gases and fumes from the lampgetting into the air breathed by the chicks. The thermometer can be lifted out, looked at and Hropped back without moving the Hover. (See illustration.) 
CONKEY'S POULTRY FEEDS AND REMEDIES

Prices Subject to Change

Conkey's Buttermilk Starting Feed. $2 \mathrm{I} / 2 \mathrm{lbs}$. $25 \mathrm{c} ; 5$
lbs. $40 \mathrm{c}: 10 \mathrm{lbs}, 70 \mathrm{c} ; 25 \mathrm{lbs}$ \% $\$ 1.65 ; 50 \mathrm{lbs}$. $\$ 3.00 ;$ lbs. $40 \mathrm{c} ; 10 \mathrm{lbs} .70 \mathrm{c} ; 25$ lbs. $\$ 1.65 ; 50$ lbs. $\$ 3.00$ 100 lbs. $\$ 5.50$, postage, express or freight extra. Conkey's Buttermilk Growing Mash. 5 lbs. 30c; 10 postage, express or freight extra.

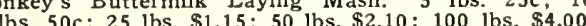
postage, express or freight extra. onkey's Chick Grains. 4 lbs. 25c: 8 lbs. 50c: 25 lbs. $\$ 1.15 ; 50$ lbs. $\$ 2.15 ; 100$ lbs. $\$ 4.15$, postage, express or freight extra. 5 lbs. 25c; 10 lbs. $50 \mathrm{c}$

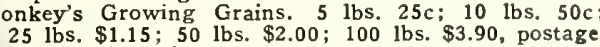
express or freight extra. Conkey's Scratch Grains. 5 lbs. $25 \mathrm{c}: 10$ lbs. 50c;
25 lbs. $90 \mathrm{c} ; 50$ lbs. $\$ 1.65 ; 100$ lbs. $\$ 3.15$, postage, Conkey's Poultry Remedies. See Page 64.

\section{PRATT'S REMEDIES FOR POULTRY}

Pratt's Poultry Regulator. Small 25c, by mail 30c. Prat's Poultry Regulator. Medium 50c, by mail 60c. $\$ 1.60$. Poultry Regulator. $25 \mathrm{lb}$. Size $\$ 3.00$ by ex
Pratt's Pout

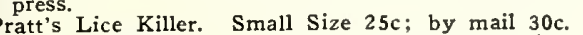
Pratt's Lice Killer. Medium Size $50 \mathrm{c}$, by mail $60 \mathrm{c}$ Pratt's Lice Salve. Tubes $25 \mathrm{c}$, by mail 30c. Pratt's Scaly Leg Ointment. 30c, by mail 35c.
Pratt's Sore Head or Chicken Pox Remedy. 30c, by

mail 35c.
Pratt's Head Lice Ointment. 30c, by mail 35c.
Pratt's Poultry Worm Remedy. 50c, by mail 60c.

Pratt's Poultry Worm Remedy. 50c, by
Pratt's Roup Remedy. 25c, by mail 30c.

Pratt's Roup Remedy. 25c, by sil $50 \mathrm{c}$, by mail $60 \mathrm{c}$

Pratt's White Diarrhea Tablets. Small Size 25c, by mail 3.0c. by mail 60 .

Pratt's Animal Regulator. 50c, by mail 60c.

\section{BURRELL-DUGGER POULTRY REMEDIES}

Avicol, for White Diarrhea. 50c, postpaid,
Avicol, for White Diarrhea. Large Size $\$ 1.00$ postDon Sung, Makes Hens Lay. 50c postpaid.

Don Sung, Makes Hens Lay. Large Size $\$ 1.00$ postRoup-Over, for Roup, Canker and Colds, 50c post. Roup-Over, for Roup, Canker and Colds. Large Size T. S. F. (Talcimized Sodium Fluoride) $40 \mathrm{c}$, postpaid. T. S. F. (Talcimized Sodium Fluoride), Medium Size 70c postpaid.

\section{GRIT AND OYSTER SHELLS}

\section{FOR POULTRY}

Fine Grit for Chickens. 6 lbs. 25c, by mail 40c; 12 lbs. $45 \mathrm{c}, 25$ lbs. $85 \mathrm{c}, 100 \mathrm{lbs} . \$ 2.00$, shipment by

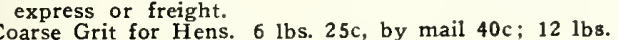
$45 \mathrm{c}, 25 \mathrm{lbs}$. $85 \mathrm{c}, 100 \mathrm{lbs}$. $\$ 2.00$, shipment by express

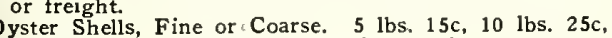
Oyster Shells, Fine or Coarse.
$25 \mathrm{lbs}$. 50c, $100 \mathrm{lbs}$. $\$ 1.25$, shipment by express or freight

\section{CHARCOAL} Fine or Coarse for Chickens. 2 lb. boxes "25c, by
mail $35 \mathrm{c}$.

\section{WALKER REMEDIES FOR POULTRY}

Walko Tablets, for White Diarrhea, Roup and Choler Toc postpaid, large size. $\$ 1.00$ postpaid.

\section{ZENOLEUM DIP AND DISINFECTANT}

8 oz. can, 40c; 1 qt., $75 \mathrm{c}$; $5 / 2$ gallon, $\$ 1.25 ; 1$ gallon, freight. Cannot be mailed.

\section{CARBOLA}

Paints and Disinfects. $5 \mathrm{lb}$. box, $75 \mathrm{c} ; 10 \mathrm{lbs} ., \$ 1.25$, postage, express or freight extra.

\section{BEE DEE STOCK REMEDIES FOR ANIMALS}

Bee Dee Stock Tonic, small size $25 \mathrm{c}$, by mail $30 \mathrm{c}$. Bee Dee Stock Tonic, medium size $50 \mathrm{c}$, by mail $60 \mathrm{c}$.

\section{BLATCHFORD'S CALF MEAL}

25 lb. bag, $\$ 1.75$

Shipment by express or freight.

\section{LICENE COMPANY REMEDIES FOR POULTRY}

Pipene, 60c postpaid.

Coldene, $60 \mathrm{c}$ postpaid.

Liverene, $60 \mathrm{c}$ postpaid.

Rumatene, 60c postpaid.

Tonene, 60c postpaid.

Licene, $60 \mathrm{c}$ postpaid.

\section{BURNETT'S UNEXCELLED BIRD FOOD}

In bottles, $35 \mathrm{c}$ each, by mail $45 \mathrm{c}$.
Burnett's Bird Tonic $25 \mathrm{c}$, by mail $35 \mathrm{c}$

\section{FRENCH'S BIRD SEED}

In boxes 20 , by mail 25

French's Bird Biscuit $15 \mathrm{c}$, by mail $20 \mathrm{c}$

\section{SPRATT'S DOG AND BIRD FOODS}

Spratt's Dog Cakes, small box 25c, by mall 30c Spratt's Dog Cakes, medium box $45 \mathrm{c}$, by mail 55c. pratt's Puppy Cakes, small size $25 c$, by mail 30c. pratt's Puppy Cakes, medium size $45 \mathrm{c}$, by mail $55 \mathrm{c}$. (s) Spratt's White Dog Soap $25 \mathrm{c}$ postpaid

Spratt's Cod Liver Oil Cage Bird and Nestling Food. $20 \mathrm{c}$ er box by mail $25 \mathrm{c}$

Spratt's Canary Mixture with Egg and Fruit 25c, by mail 30 .

Spratt's Parrot Mixture, 20c, by mail 25c.

Spratt's Canary Color Food (red), $25 \mathrm{c}$ postpaid. pratt's Canary Color Food (orange), 25c postpaid. Spratt's Aquarium Fish Food, $10 \mathrm{c}$ per box, by mai

\section{MILLER'S DOG FOODS}

Miller's A1 Dog Ration, $5 \mathrm{lb}$. box 60c; by mail 70c; $25 \mathrm{lb}$. bag, $\$ 2.00 ; 50$ lb. bag, $\$ 3.50 ; 100 \mathrm{lb}$. bag,

Miller's A1 Dog Biscuits, $2 \mathrm{lb}$, box, $35 \mathrm{c}$, by mail $45 \mathrm{c}$;
$25 \mathrm{lb}$. bag. $\$ 2.75 ; 100 \mathrm{lb}$. bag, $\$ 8.50$, not prepaid.

\section{SERGEANT'S DOG REMEDIES}

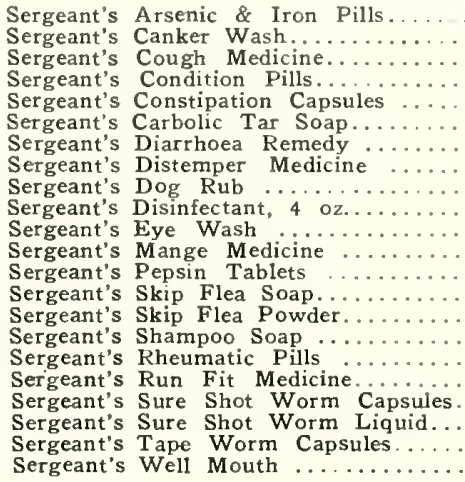

\section{LAWN MOWERS}

The Van Antwerp-An excellent mower for home lawns. This mower has 4 crucible tool steel, hard ened and tempered blades. The parts are malleable cut can be adjusted to $\mathrm{x} / 2$ inch to $11 / 2$ inches and it will cut grass 5 inches high. Wheels eight inches in diameter with spoked rim. This is a very attractive mower with aluminum frame and cylinder; gold Wheels with gold and red stripes. Prices-The Van Antwerp Mower, 14 inch cut size, $\$ 9.50 ; 16$ inch cut

Quaker City Mower-This mower is made by the Pennsylvania Lawn Mower Company. It is a ball bearing mower with 5 blades made of crucible tool hardened steel cup and cones, quatric ball bearings, ment Low type wheels and self-sharpening knives. Height of cut, $1 / 2$ inch to $11 / 2$ inches. This is a splen did mower and one of our best sellers. Price-14 inch cut, $\$ 18.00$; not prepaid.

\section{WISS PRUNING SHEARS}

No. $109, \$ 3.50$; No. $309, \$ 2.50$; No. $209, \$ 1.50$ Wiss Orange Clippers, No. C2, with thumb notch,
$\$ 1.00 ;$ No. C1, without thumb notch, $75 \mathrm{c}$, all postpaid.

\section{PRUNING SAWS}

Disston Adjustable Pruning Saws, $\$ 2.50$ each, postpaid. paid.

\section{MILK BOTTLE CAPS}

Grade A, Grade B, Plain Caps (marked Wash and Return). Prices-lb. (about 500 caps), $35 \mathrm{c}$, by mail
$45 \mathrm{c}$; box of 5,000 caps, $\$ 2.00$; box of 50,000 caps. $45 \mathrm{c}$; box of 5,000 caps, $\$ 2.00$; box
$\$ 17.50$, shipment by express or freight.

\section{Van Antwerp's Day Old Chicks Parcel Post}

It is cheaper to buy BABY CHICKS and keep your hens laying while eggs are high during the winter and early spring months. We will start shipping baby chicks about January 15th and will continue to ship until May 15th, 1928. We will make shipnrents on Tuesdays and Thursdays of each week. We guarantee live delivery of Healthy Pure Bred Baby Chicks at the prices quoted on this page. If you order seeds also baby chicks, you will receive two separate shipments as the chicks are of course shipped direct to you from our hatchery. Remember, No Chicks Shipped C. O. D. We pay the postage or express at the following prices:

BREEDS

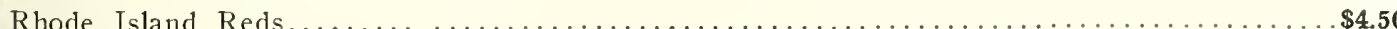

Barred Rocks

White Rocks

White Wyandottes

Buff Orpingtons

S. C. White Leghorns

S. C. Brown Leghorns

Mixed Heavy Breeds..

$\begin{array}{rrr}25 & 50 & 100 \\ \$ 4.50 & \$ 8.50 & \$ 16.00 \\ 4.50 & 8.50 & 16.00 \\ 4.50 & 8.50 & 16.00 \\ 4.75 & 9.00 & 17.00 \\ 4.75 & 9.00 & 17.00 \\ 4.25 & 8.00 & 15.00 \\ 4.25 & 8.00 & 15.00 \\ 3.75 & 7.00 & 13.0\end{array}$

100
16.00
16.00
16.00
17.00
17.00
15.00
15.00
13.00

500

$\$ 70.00$

70.00

70.00

75.00

75.00

65.00

65.00

60.00

1000

$\$ 135.00$ 135.00 135.00 145.00 145.00

125.00

125.00

115.08 


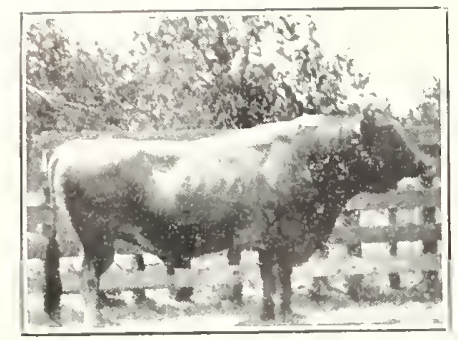

POGIS 99TH OF HOOD

FARM $57 \mathrm{TH}$

A.J.C.C. 170476

His dam's Register of Merit Record as a 4 year old $14,485.7$ lbs. Milk 928.3 lbs. Butter.

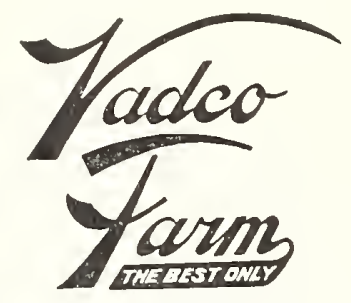

FARM OWNED AND OPERATED BY

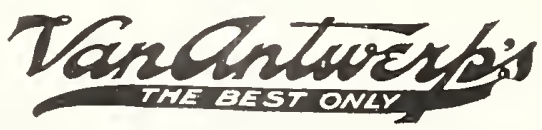

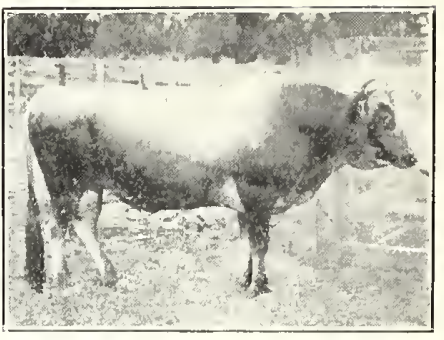

SOPHIE 19TH'S SON $19 \mathrm{TH}$ A.J.C.C. 196892

His dam has five consecutive Register of Merit Records aggregating 76,263 lbs. Milk $4,454.5$ lbs. Butter.

\section{U. S. ACCREDITED HERD}

\section{POGIS 99th OF HOOD FARM 57th 170476}

Picture shown above is Senior Herd Sire at Vadco Farm. His blood is infused into almost our entire herd: of his daughters many have made the Register of Merit, two of them have made Silver Medals for high production, the average fat percentage of his daughters being 5.50 with an exceptional flow of milk.

\section{SOPHIE 19th's SON 19th 196892}

This bull until the time of his death was Junior Herd Sire at Vadco Farm, he was selected to mate to our Pogis' daughters. This mating turned out to be as good as we expected. For example look at his daughter Soson Pogabelle shown on the lower right of this page. We easily have twenty-five of her sisters that equal her in type and production.

\section{EMINENT'S KITTY A. J. C. C. 298199}

One of our many foundation cows with a Register of Merit Record. This cow is a very old matron. The fact is she is in her fifteenth year, but look at her picture taken this montl. She looks as smooth and as fine as if she were ten years younger. In spite of this cow's age she has completed this year a lactation period in which she produced $8,546.8 \mathrm{lbs}$. of milk in less than 300 days and carried a calf during the period 220 days. Think of this; nearly $31 / 2$ gallons of milk per day for a fifteen-year-old cow!

\section{SOSON POGABELLE A. J. C. C. 624919}

One of old Eminent's Kitty's great granddaughters who produced during her lactation period as a two-year-old $7,332 \mathrm{lbs}$. of milk and carried a calf during the period 218 days. She is by Sophie 19th's Son 19th and out of a Pogis 99th of Hood Farm 57th's daughter.

\section{START YOUR HERD RIGHT BY BUYING A VADCO FARM BULL}

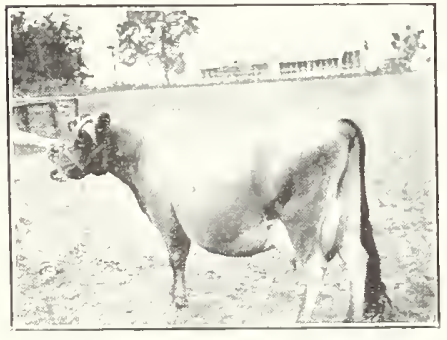

EMINET'S KITTY A.J.C.C. 298199

The kind of a cow to build to. Strong, rugged constitution. Good looker and a good producer.

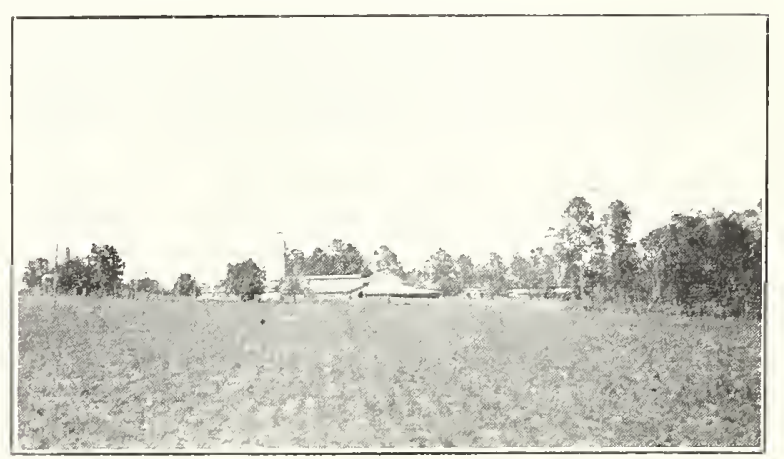

View of Farm Buildings from across one of our fields.

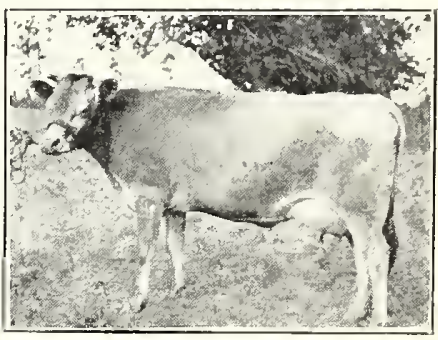

SOSON POGABELLE A.J.C.C. 624919

A beautiful animal with high production. 


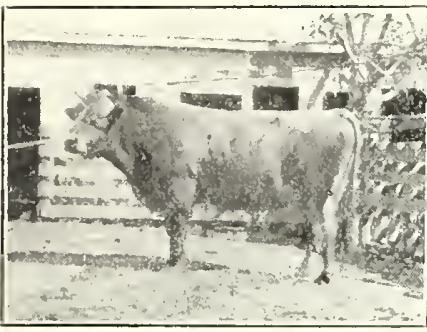

ST. MAWES LAD SUNBEAM A.J.C.C. 231839

Coming from a herd that had the distinction of being the highest producing herd in the world.

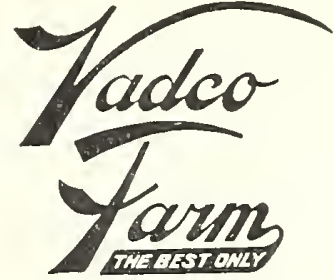

FARM OWNED AND OPERATED BY

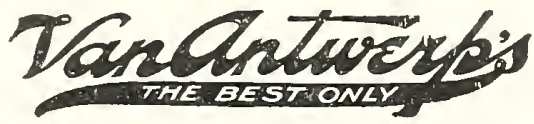

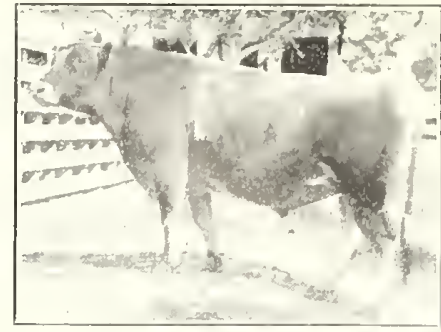

NOBLE'S MAID'S PRINCE RALEIGH

A.J.C.C. 257468

One of the typest sires we have ever owned.

\section{U. S. ACCREDITED HERD}

\section{ST. MAWES LAD SUNBEAM A. J. C. C.}

\section{9}

A double grandson of St. Mawes Lad, the bull that materially helped to put the State of Oregon on the dairy map by both the high production and consistent performance of its Jersey cows at the milk pail.

This bull became our Junior Herd Sire after the death of our Sophie 19th's Son 19th.

\section{NOBLE'S MAID'S PRINCE RALEIGH}

\section{A. J. C. C. 257468}

This is a very young bull, being just past two years, but he has both production and type. His dam is a Silver Medal cow, having produced in 305 days at 3 years and 2 months of age 564 lbs. 14 ozs. of
$85 \%$ Butter and this record made in Class AAA. This bull was selected to mate with St. Mawes Lad Sunbeam's daughters.

ST. MAWES POGIOLA A. J. C. C. 699376

One of St. Mawes Lad Sunbeam's daughters, she is 18 months old and she is out of a daughter of Pogis 99th of Hood Farm 57th; she is also a granddaughter of old Eminent's Kitty. St. Mawes Pogiola is in calf to Noble's Maid's Prince Raleigh.

\section{ST. MAWES IDILIO A. J. C. C. 740294}

This heifer is also a daughter of St. Nawes Lad Sunbeam and out of a Pogis' daughter. She is only 14 months old witls a wonderful udder placement and just bred to Noble's Maid's Prince Raleigh.

\section{A VADCO FARM BULL WILL MAKE MONEY FOR YOU}

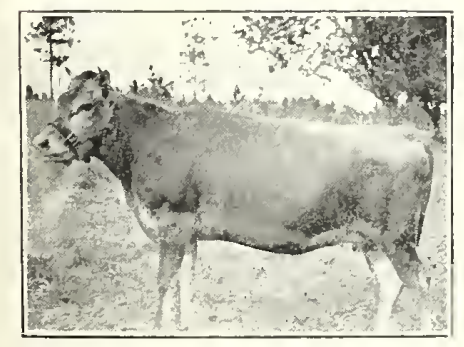

ST. MAWES IDILIO A.J.C.C. 740294

This yourg heifer is most certain to be a high producer of milk and butter.

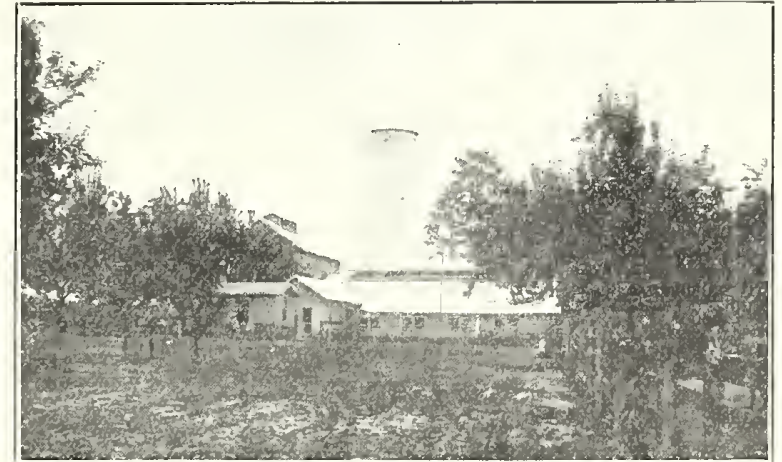

View of the Milking Barn at Vadco Farm, showing 250 ton silo connected with barn.

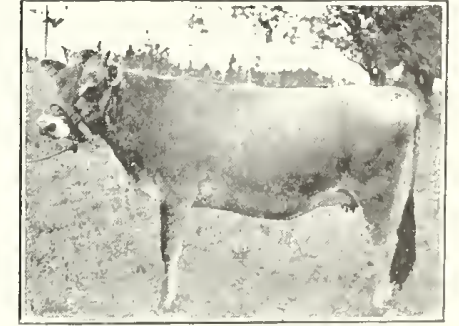

ST. MAWES POGIOLA A.J.C.C. 699376

A young heifer only a year and a half old, but look at her udder development and say,

"Yes, she is going to be a milking machine." 


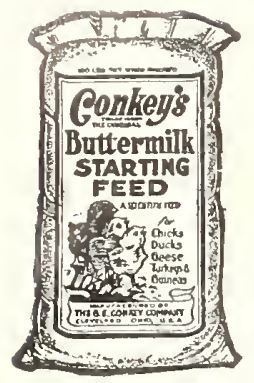

\section{Conkeys \\ THE ORIGINAL \\ BUTTERMILK STARTING FEED}

Feed It for Eight Weeks and Raise Every Chick You Hatch

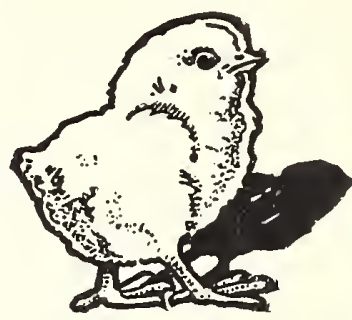

A Ready Prepared Mash for baby chicks and all self-feeding young fow 1 s. This remarkable feed-originated by Conkey and prepared through proc

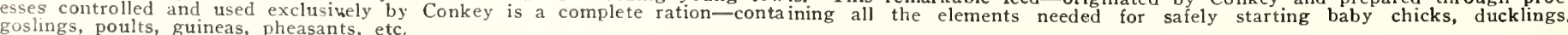
Guaranteed Analysis Crude Protein, 12\%; Crude Fibre, 4\%: Crude Fat, 3\%; Nitrogen Free
Extract, $56 \%$; Carbohydrates, $60 \%$.

Semi-solid buttermi!k, finhead oatmeal, a meal, corn feed meal and granulated bone.

Price, 21/2 lbs, 25c; $5 \mathrm{lbs}$., 40c; $10 \mathrm{lbs}$., 70c. Add postage at zone rates shown on page 2 . Write for quantity prices.

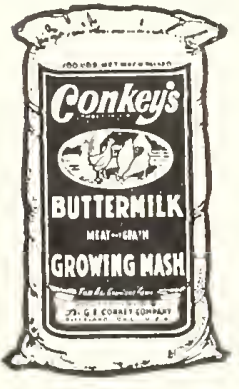

\section{Conkevs}

Buttermilk Growing Mash

Crude Prorein, 18\%: Crude Fibre, 5\%; Crude Fat, 4\%; Ingredients

Semi-solid buttermilk, wheat middlings, wheat bran, corn feed meal, ground barley, hulled oats, bone, meat scraps, bean meal and on meal.

This mash-second link in the Conkey Chain-is fed after the chicks are eight weeks old. It is balanced for rapid and even development of muscles, bones, vital organs and reathers. Like all Conkey mashes it is low in fibre, clean and always Price, 5 lbs., 30c; 10 lbs., 60c. Postage extra Write for quantity prices.

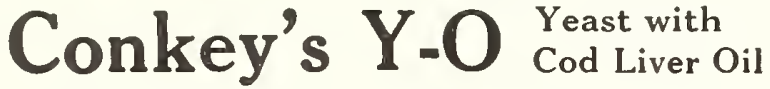

Poultry experts advise that cod liver oil and yeast be added to all poultry rations to supply needed "v

modern "forcing" methods. brewers' strength of hoth substances, and gives the poultryman a handy, practical, cheap method of feeding "vitamin"s".

Conkey's Y-O is a chocolate-brown powder, which is free running and readily mixed with dry mashes. It has the savory odor of clean, sweet, freshly-refined

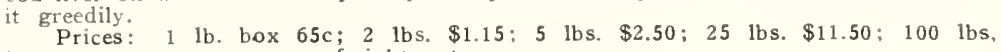
$\$ 32.50$, postage, express or freight extra.

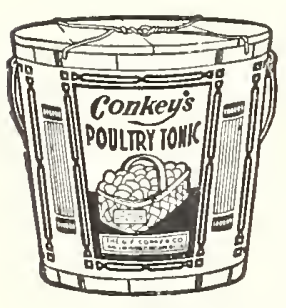

\section{Conkey's Poultry Tonic}

Helps birds get more out of their feed; they produce more eggs and better flesh on LESS FEED, by better digestion and assimilation, Conkey's Tonic is all medicine-tree
from filler, red pepper, and "hot stuff" to overstimulate the birds and break down their health. Keeps the young chicks growing, makes molting easy, strengthens the bird for bad Prices-Packages, $11 / 2$ lbs., 25c; $31 / 4$ lbs, $50 \mathrm{c} ; 7$ lbs. $\$ 1,00$; pails, 12 lbs., $\$ 1.60 ; 25$ lbs., $\$ 3.00$; bags, 50 lbs., charges extra.

\section{Conkey's Roup Remedy}

When Roup breaks out there's no time to experiment-start treatment at once-the disease is very contagious. When birds sneeze, froth in eyes, or run always at the first sign of "roupy weather," place Conkey's Roup Remedy in fountains-it's a great preventive

Prices-Packages, 25c,50c, $\$ 1.00$; or $30 \mathrm{c}, 55 \mathrm{c}, \$ 1.20$ postpaid; $1 \mathrm{I} / 2 \mathrm{lb}$. can, $\$ 2.50$ postpaid; breeder size ( $5 \mathrm{lb}$, can),
$\$ 5.75$ postpaid.

\section{Conkey's Roup Pills}

For treating individual cases and for use at shows when Prites develop colds.

Prices-Packages, $25 \mathrm{c}, 50 \mathrm{c}, \$ 1.00$; or $30 \mathrm{c}, 55 \mathrm{c}, \$ 1.20$ postpard; breeder size ( 1,000 pills), $\$ 3.00$; or $\$ 3.10$ postpaid.

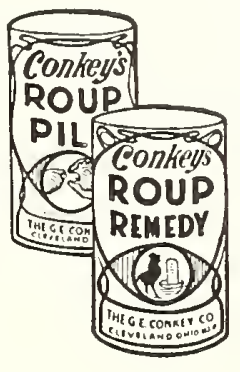

\section{Conkey's White Diarrhea Remedy}

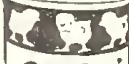

conkelis

WHITE

DIARRHFA

TABLETS

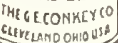

Once you have used this old reliable preparation you will never be without it. As a preventive of bowel troubles, White Diarrhea and other digestive complaints, it has given great satisfaction for many years. Once started diarrhetic conditions often sweep away the whole hatch-hundreds of chicks. Play safe-keep this remedy in the drink. ing water until the danger period is past. This remedy is also recommended as a preventive measure and for treatment of coccidiosis.

\section{Conkeys}

Buttermilk Laying Mash

Crude Protein 20\%; Crude Fibre, 6\%; Crude Fat, $4 \%$ : Crude Protein, $20 \%$; Crude Fibre, 6\%; Crude
Nitrogen Free Extract, $44 \%$; Carbohydrates, $50 \%$

$$
\text { Ingredients }
$$

Semi-solid buttermilk, corn meal, corn feed meal, ground barley, wheat bran, wheat middlings, oil meal, bone, mea scraps and bean meal.

The third link in the Conkey Chain is balanced for a full egg basket. Low in fibre, just right in protein for layers. Price, 5 lbs., 25c; 10 lbs., 50c. Postage extra. Write for quantity prices.
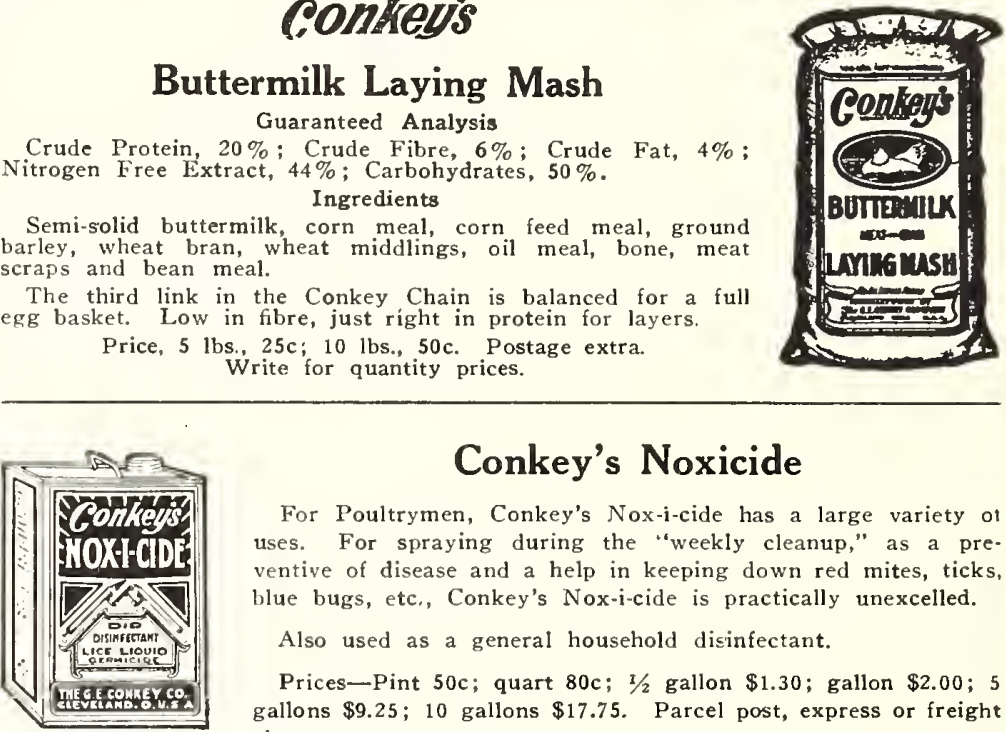

\section{Conkey's Noxicide}

For Poultrymen, Conkey's Nox-i-cide has a large variety of uses. For spraying during the "weekly cleanup," as a pre ventive of disease and a help in keeping down red mites, ticks, blue bugs, etc, Conkey's Nox-i-cide is practically unexcelled.

Also used as a general household disinfectant.

Prices-Pint 50c; quart $80 c$; $1 / 2$ gallon $\$ 1.30$; gallon $\$ 2.00 ; 5$ gallons $\$ 9.25 ; 10$ gallons $\$ 17.75$. Parcel post, express or freight charges extra.

\section{Conkey's Canker and Bronchitis Remedy}

Prices-Pkg. 50c; or $55 \mathrm{c}$ postpaid.

Conkey's Poultry Laxative

Prices-Pkgs, 25c, 50c; or 30c, 55c postpaid; breeder size (5 lbs.), $\$ 2.75$; or $\$ 2.90$ postpaid

\section{Conkey's Poultry Conditioner}

Prices-Pkgs. 25c, 50c; or 30c, 55c postpaid.

Conkey's Limberneck Remedy

Prices-Pkg, 50c; or 55c postpaid.

Conkey's Scaly Leg Remedy

Prices-Pkg. $25 \mathrm{c}$; or $30 \mathrm{c}$ postpaid.

Conkey's Poultry Worm Remedy

Prices-Pkgs. 25c, 50c; or 30c, 55c postpaid; breeder size (5 lbs.), $\$ 2.75$; or $\$ 2.85$ postpaid

Conkey's Blackhead Remedy

Prices-Pkg. $50 \mathrm{c}$; or $55 \mathrm{c}$ postpaid.

Conkey's Cholera Remedy Prices-Pkgs. $25 \mathrm{c}, 50 \mathrm{c}, \$ 1.00$; or $30 \mathrm{c}, 55 \mathrm{c}, \$ 1.10$ postpaid; breeder size (5 lbs.).
$\$ 2.50$; or $\$ 2.65$ postpaid.

\section{Conkey's Lice Powder \\ (Contains Sodium Fluoride)}

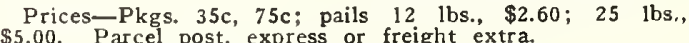

Conkey's Mite Liquid Prices-Cans, qt. 60c; 2 qt., 90c; gal., $\$ 1.50 ; 5$ gal.,
$\$ 7.00$. Parcel post, express or freight extra.

Conkey's Head Lice Ointment Prices-Pkg. 25c; or 30c postpaid.

Conkey's Lice Fix

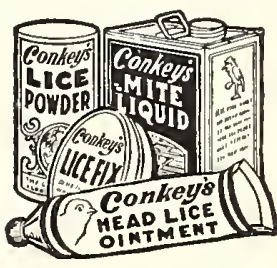

Prices-Pkgs, 25c, 50c; or 30c, 55c postpaid. 
Please do not writel̆in above space.

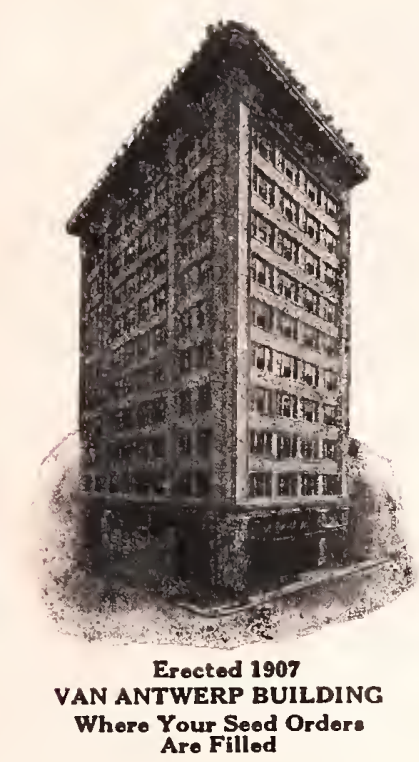

Order No...............

Filled by...

Checked by............

Please do not write in above space.

- If goods are wanted C. O. D. 25 per cent. of amount must accompany the order.

No plants shipped C. O. D.

\section{SEED ORDER BLANK ${ }_{1928}^{\text {For }}$}

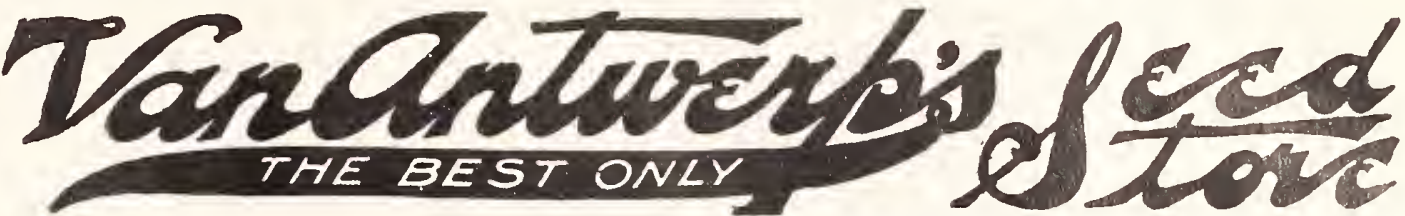

MOBILE, ALABAMA

\section{BE SURE TO FILL OUT THESE BLANKS PLAINLY. The more careful you NOTCCE_are in filling out the following blanks plainly and correctly, the more certain you are of receiving your order promptly and satisfactorily.}

Gentlemen -1 am enclosing $\ldots \ldots \ldots \ldots \ldots \ldots \ldots \ldots \ldots$ for the following seeds to be sent by

(State here if wanted by Mail, Express or Freight.)

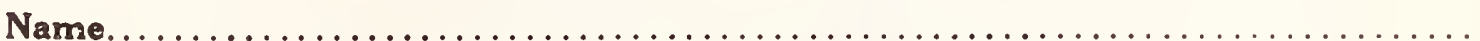
(If Mra. kindly une husband's initiels or give anme, as Mrs. John W. Jones.)

P. O.

R. F. D. No.

Box No.

State. . . . . . . . . . . . .

Express or Freight Office.

(Il dillereat trom your Pont Office.)

SEEDS POSTPAID BY PARCEL POST-Please bear in mind that the prices given in our catalog include delivery on all seeds by packet ounce, quarter pound, pounds. iwo pound, and 5 pound lots, unless otherwise specified, to all post offices within the boundaries of the United States.

Send us the amount named in our catalog, and we guarantee safe delivery by postpaid parcel post in these quantities. This does not include pecks and buabels

\begin{tabular}{|c|c|c|c|c|}
\hline $\begin{array}{l}\text { CATALOG } \\
\text { NUMBER }\end{array}$ & QUANTITY & Names of Seeds or Other Articles Wanted & Dollers $\mathrm{PRICE}$ & Conts \\
\hline & & & & \\
\hline & & & & \\
\hline & & & & \\
\hline & & & & \\
\hline & & & & \\
\hline & & & & \\
\hline & & & & \\
\hline & & & & \\
\hline & & & & \\
\hline & & & & \\
\hline & & & & \\
\hline & & & & \\
\hline & & & & \\
\hline & & & & \\
\hline & & & & \\
\hline & & & & \\
\hline & & & & \\
\hline & & Amount carried forward & & \\
\hline & & $\begin{array}{ll} & \text { TOTAL } \\
\end{array}$ & & \\
\hline
\end{tabular}




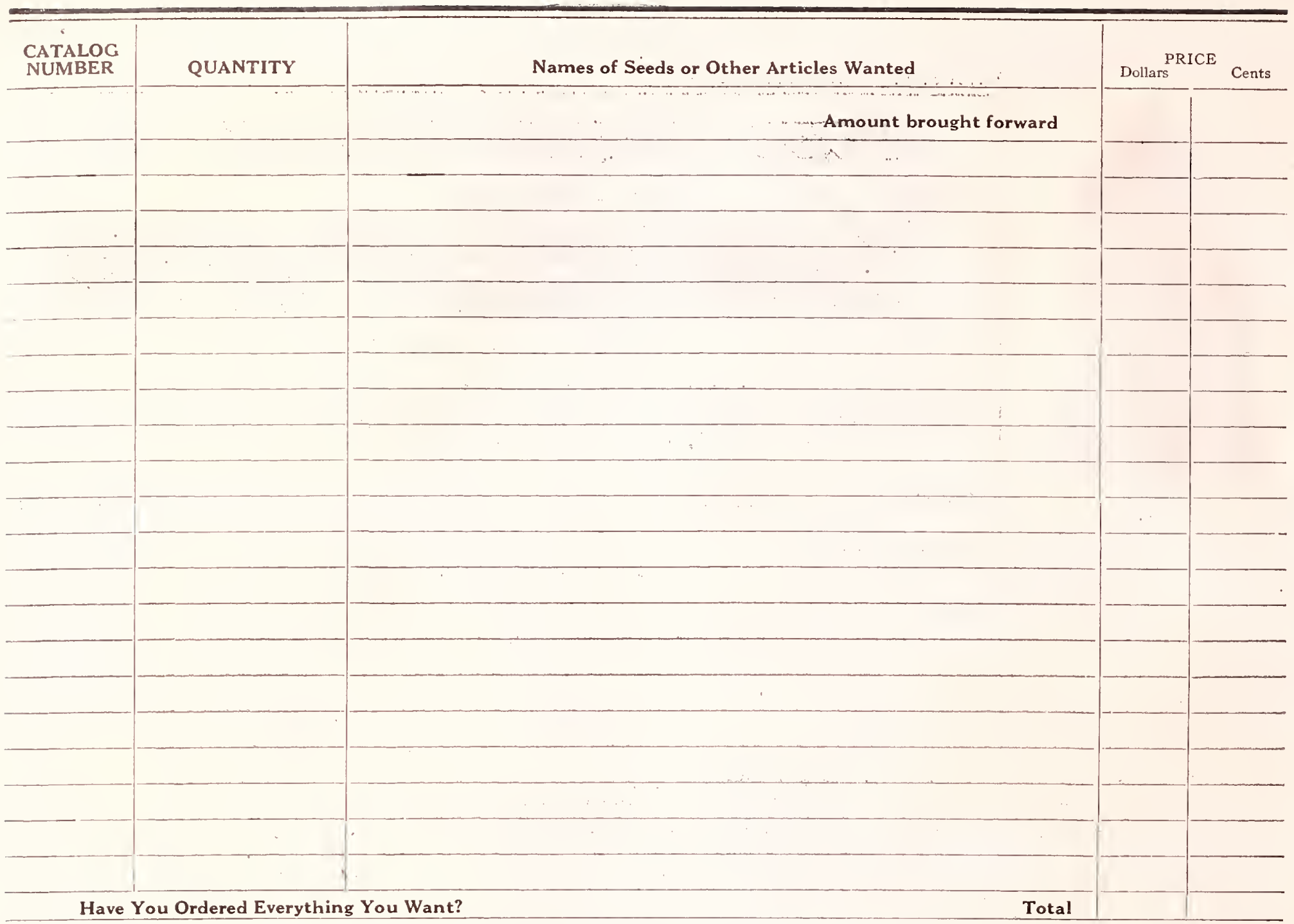

\section{YOUR SAVING IS IN VAN ANTWERP'S PROFIT-SHARING CERTIFICATES}

See Page 3 for Complete Information About These Certificates

We are anxious to obtain the names and correct postoffice addresses of a number of your friends and acquaintances who are farmers

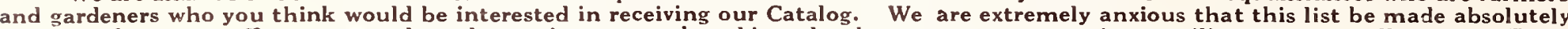

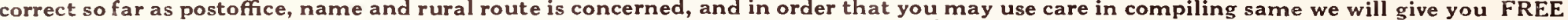

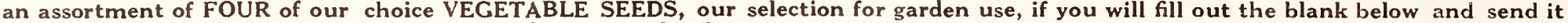
with an order for Seed or other articles selected from our Catalog.

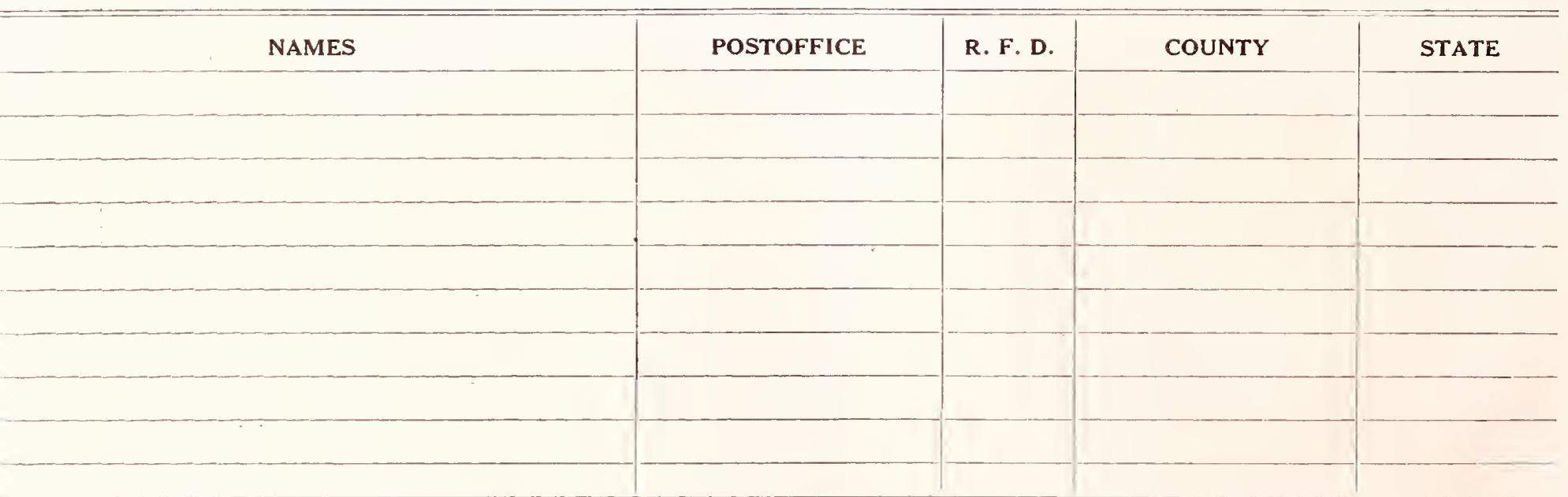

To Van Antwerp's Seed Store-The above list of names is correct.

Please sign your name and address here:

In accordance with the universal custom of the Seed Trade, Van Antwerp's Seed Store gives no warranty, express or implied, as to description, quality, productiveness, or any other

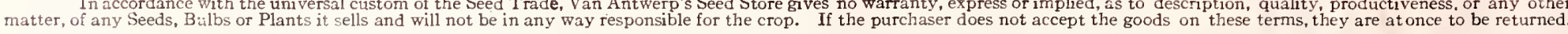



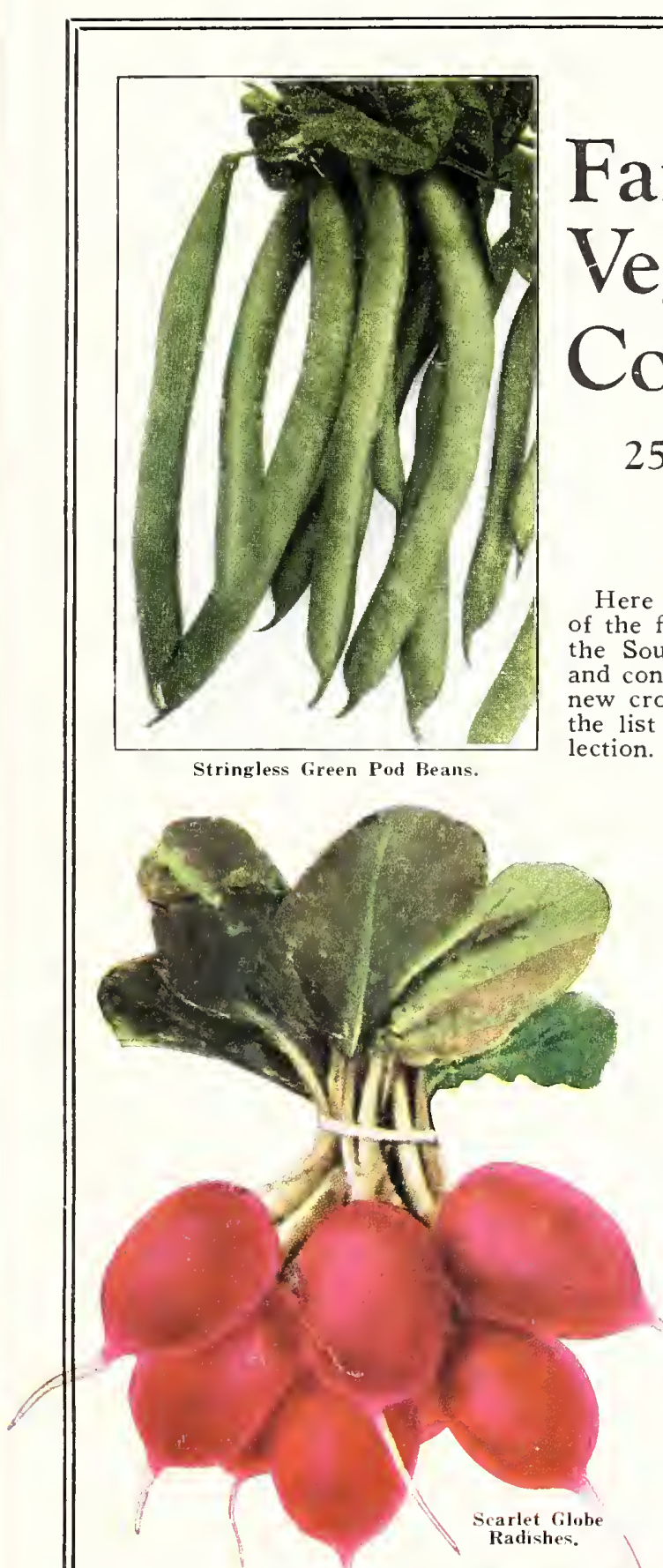

Here is a choice collection of 25 varieties of the finest vegetable seeds for planting in the South. It is a real bargain collection and contains 25 well filled packets of strictly new crop fresh vegetable seeds. Read over the list below of what you get in this collection. As a special 1928 ofter you get the 25 packets for $\$ 1.00$, postpaid. Bought separately the 25 packets would cost you $\$ 2.00$

1 Pkt. Southern Market Beets 1 Pkt. All Head Cabbage

1 Pkt. Rocky Ford Cantaloupe 1 Pkt. Stowell's Evergreen Corn 1 Pkt. Red Creole Onion

1 Pkt. Extra Early Peas

1 Pkt. Ruby King Pepper

1 Pkt. Curled Parsley

1 Pkt. Scarlet Globe Radish

1 Pkt. White Bush Squash

1 Pkt. Earliana Tomato

1 Pkt. Half-Long French Carrot

1 Pkt. Stringless Green Pod Beans

1 Pkt. Vadco Wonder Cucumbers

1 Pkt. Tom Watson Watermelon

1 Pkt. Purple Top Rutabaga

1 Pkt. Big Boston Lettuce

1 Plkt. Dwarf Green Okra

1 Pkt. Southern Curled Mustard

1 Pkt. Red Top Turnip

1 Pkt. Seven Top Turnip

1 Pkt. Henderson's Bush Butter Beans

1 Pkt. Kentucky Wonder Pole Beans

1 Pkt. New Orleans Market Eggplant

1 Pkt. Mammoth Pumpkin

For one dollar we will send you the above collection of vegetables (25 varieties) postpaid to your home, including a free book of planting instructions. No changes will be allowed.
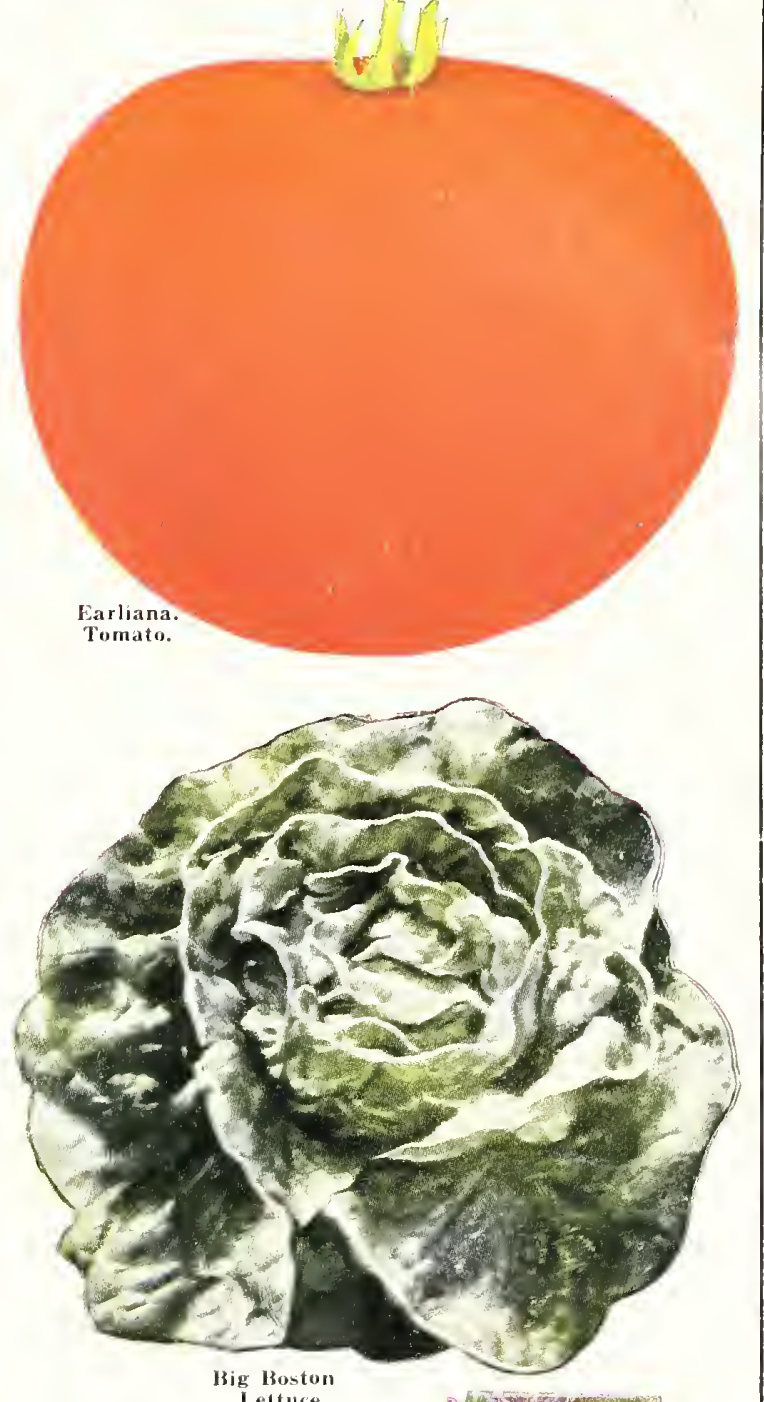

Mig Boston

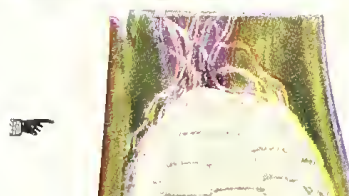

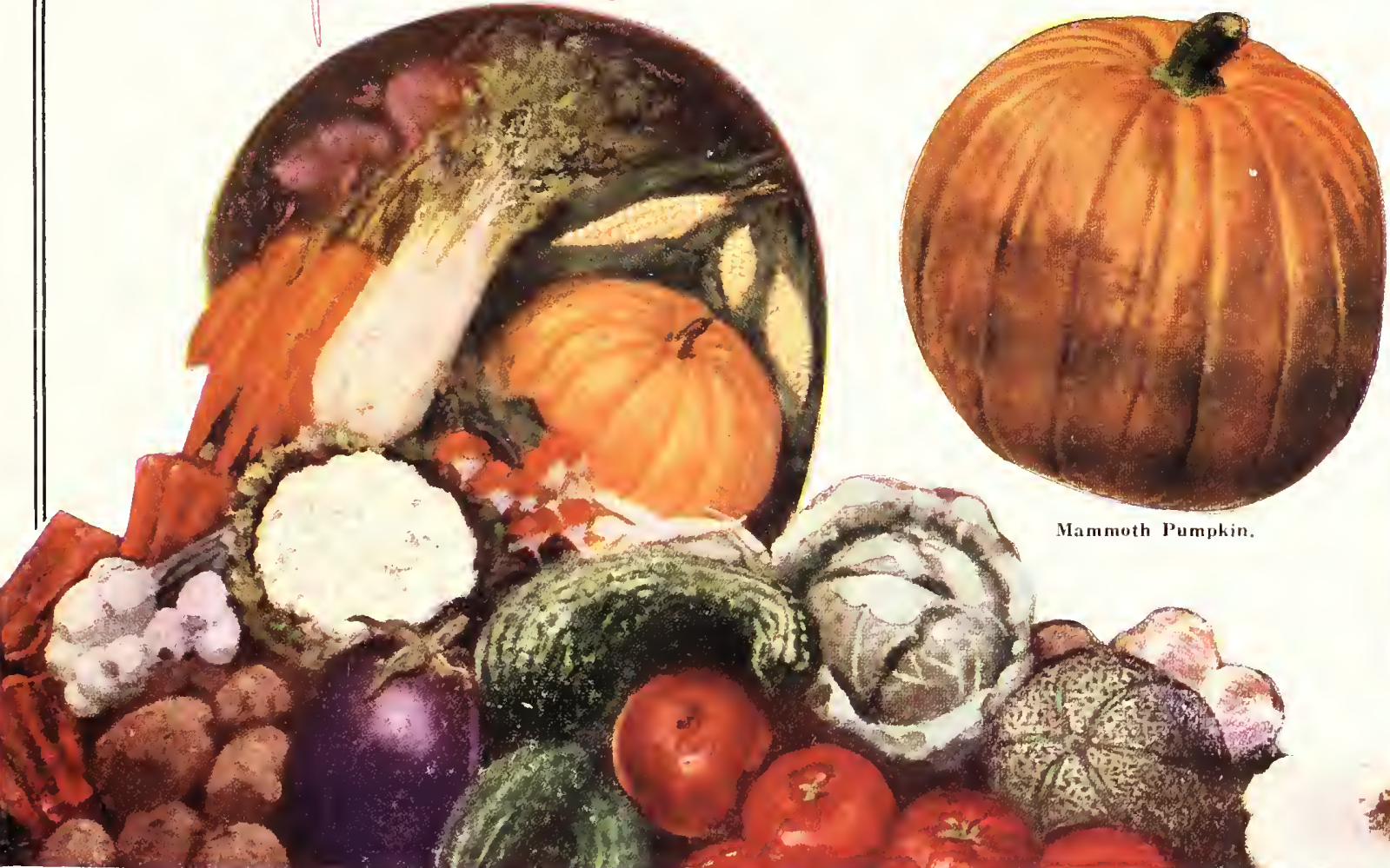




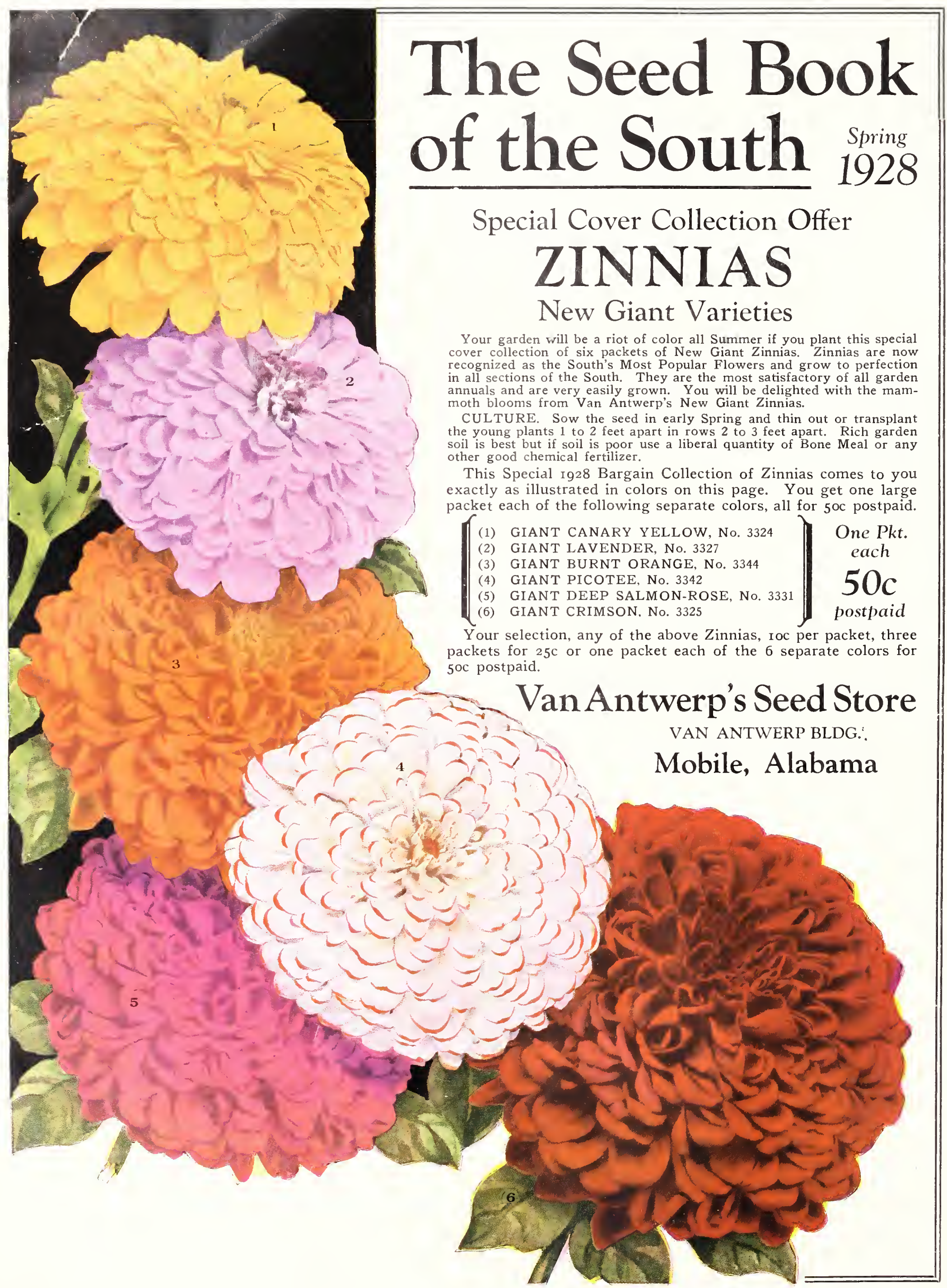

